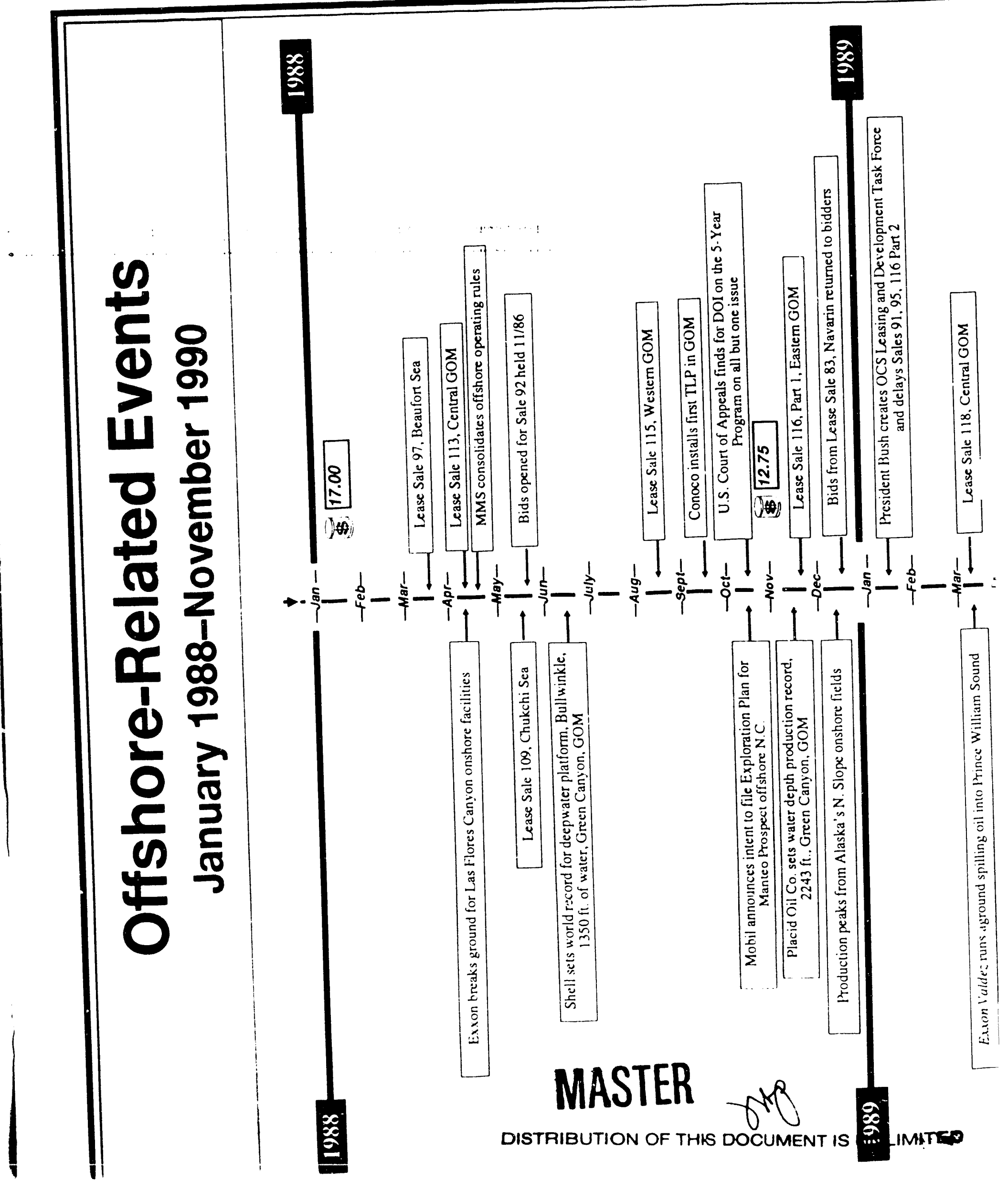




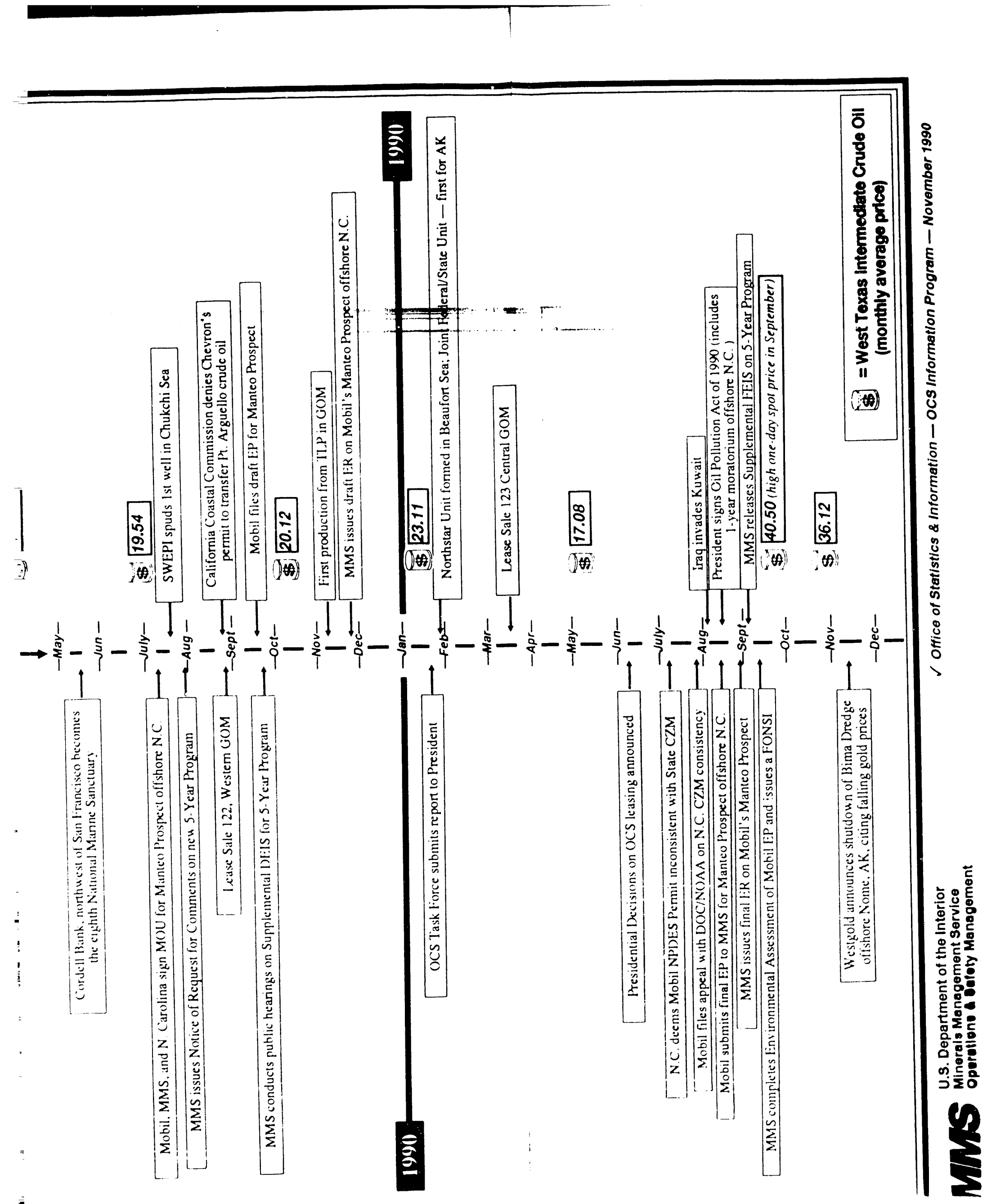




\section{OCS National Compendium}

OCS/MMS--91-0032

TI9 2003028

Outer Continental Shelf Oil \& Gas

Information through October 1990

By

Gregory J. Gould

Robert M. Karpas

Douglas L. Slitor

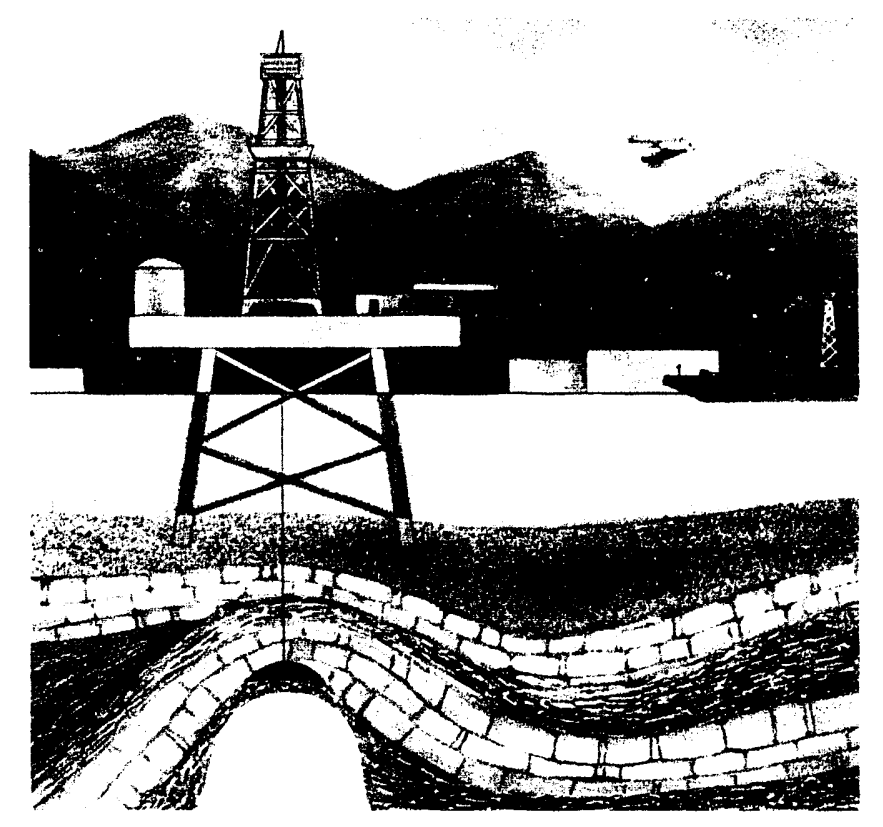




\section{Preface}

The Outer Continental Shelf Information Program (OCSIP) was mandated by the 1978 Amendments to the OCS Lands Act (43 U.S.C. 1352). To meet the requirements of this mandate, the OCSIP has made available two types of documents (summary reports and indexes) that have described oil- and gas-related activities in each of the four Minerals Management Service (MMS) OCS Regions: the Alaska, the Atlantic, the Gulf of Mexico, and the Pacific.

Many facets of the Federal oil and gas leasing program have changed significantly in the 12 years since inception of the OCSIP. In recognition of these changes, and in an attempt to reduce administrative costs, the OCSIP has recently modified its publication program and now produces the following documents:

$\neg$ a streamlined Update report for each of the four MMS OCS Regions (in lieu of the Summary Reports published formerly);

$\mathcal{J}$ an OCS National Compendium that presents historical information on all of the OCS Regions;

J a map series detailing regional offshore and onshore information for the Alaska and Pacific OCS Regions;

$J$ an OCS Directory of Federal and State agencies and their OCS responsibilities; and

J a quarterly statistical data report called $M M S$ Offshore Stats.
To order any of these documents, or for more information about them, contact the OCSIP at the following address and telephone number:

OCS Information Program

Minerals Management Service, MS 4610 381 Elden St.

Herndon, VA $22070-4817$

(703) 787-1080 or (FTS) 393-1080 


\section{Abbreviations and Acronyms}

A $\begin{array}{ll}\text { ACOE } & \text { - Ammy Corps of Engineers } \\ \text { APD } & \text { - Application for Permit to Dril } \\ \text { API } & \text { - American Petroleum Institute } \\ \text { ARCO } & \text { - Atantic Richfield Company }\end{array}$

\section{B}

Bbbl - billion harrels

bbl - barrels

BBO - billion barrels of oil

BBOE - billion harrels of oil equivalent

Bcf - billion cubic feet

BOE - barrels of oil equivalent

BOPD - barrels of oil per day

Btu - British thermal unit

C

Cle - California Coastal Commission

CCORS - California Comprehensive (of fshore Resoures Study

CERCLA - Comprehensive Environmental Response,

Compensation, and I. iability Act

CEQA - Califomia Environmental Quality Act

CFR - Code of Federal Regulations

COST - Continental Offshore Stratigraphic Test

CSC - Cooperative Siecring Committee

CTGS - Central Texas Gathering System

CWA - Clean Water Act

CZM - Coastal Zone Management

CZMA - Coastal Zone Management Act

CZMP - Coastal Zone Management lrogram

D

IDEC - Department of Environmental Conservation

I)(OCI) - Development ()perations Coordination

Document

D)I - Department of the Interior

DOT - Department of 'Transportation

DPP - development and production plan

DSDP - Deep Sea Drilling Project

dwt - deadweight ton

\section{$E$}

I:GOM - Eastern Gulf of Mexico

EIR - environmental impact report

EIR/S - environmental impact reportstatement

I:IS

I:P

$\operatorname{IPA}$

I:SP

I:QAP

\section{$\mathbf{F}$}

IDP $\quad$ - Final Derelopment Plan

FONSI - Finding of No Significant Impact

lik Federal Register

fis - federal Telephone System
G

gal

GAO

GGCP

GIMT

H

HIOS - High Island Offshore System

I

IMO - International Maritime Organization

K

KSSD - Kodiak Shelf Stratigraphic Drilling

KSST - Kodiak Shelf Stratigraphic Test

L

LPG - liçuid petrolcum gas

M

m - meter(s)

Mbbl - thousand barrels

MBOE - thousand harrels of oil equivaleat

Mbped - thousand barrels per calendar day

Mhpd - thousand harrels per day

Mcf - thousand cubic feet

Mefd - thousand cubic feet per day

$\mathrm{mD} \quad-$ millidarcy

MEMS - Marine Emergency Management Study

MMhbl - million harrels

MMBO - million harels of oil

MMbpd - million harrels per day

MMbped - million harrels per calendar day

MMcld - million cuhic feet per day

MMS - Minerals Management Service

MOEPSI - Mohil ()il Fxploration \& Producing Southeast, Inc. (Mobil)

MP - Management Plan

MS - Mail Stop

M.Y. - million years

$\mathbf{N}$

NCP - National Contingency Plan

NEPA - National linvironmental Police Aet

NGL - natural gas liquids

NMS National Marine Sancluary

NOAA - National Oceanic \& Amospheric Administration

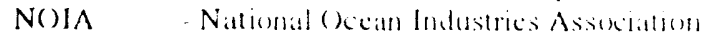

NOS - Nationatecan Service

NPRA - National Petroleum Reserve-Alaskia

NRC - National Resource Council

NRIC - Natural Resources I) fense Council 
0

$\begin{array}{ll}\text { OCRM } & \begin{array}{l}\text { - Office of Ocean \& Coastal Resource } \\ \text { Management }\end{array} \\ \text { OCS } & \text { - Outer Continental Shelf } \\ \text { OCSEAP } & \text { - OCS Environmental Assessment Program } \\ \text { OCSIP } & \text { - Outer Continental Shelf Information Program } \\ \text { OCSLA } & \text { - Outer Continental Shelf Lands Act } \\ \text { OFR } & \text { - open-file report } \\ \text { OHMSETT } & \text { - Oil and Hazardous Materials Simulated } \\ & \text { Environmental Test Tank } \\ \text { OPD } & \text { - official protraction diagram } \\ \text { OPEC } & \text { - Organizations of Petroleum Exporting Countries } \\ \text { ORAP } & \text { - (Wash.) Ocean Resources Assessment Program } \\ \text { ORMP } & \text { - (Oreg.) Ocean Resources Management Plan } \\ \text { OS\&T } & \text { - offshore storage and treating (vessel) } \\ \text { OSC } & \text { - On-Scene Coordinator } \\ \text { OTP } & \text { - Oil Transportation Plan }\end{array}$

U

Unocal - Union Oil Company of California

U.S. - United States

U.S.C. - United States Code

USCG - United States Coast Guard

USGS - United States Geological Survey

\section{W}

WGOM - Western Gulf of Mexico

WOGA - Western Oil \& Gas Association

WSPA - Westem States Petroleum Association (formerly WOGA)

$\mathbf{P}$

Pactex - Pacific Texas Pipeline

PANGL - Point Arguello Natural Gas Line Company

PAOS - Point Arguello Offshore System

PAPCO - Point Arguello Pipeline Company

PARS - Port Access Route Studies

PDP - Preliminary Development Plan

P.L. - public law

PLN - Proposed Leasing Notice

POPCO - Pacific Offshore Pipeline Company

PRESTO - Probabilistic Resource Estimates-Offshore

PWSA - Ports and Waterways Safety Act

R

RRT - Regional Response Team

RTWG - Regional Technical Working Group

S

SALM - single anchor leg mooring

SCPS - Southem California Pipeline System

SEIR - supplemental environmental impact report

SEIS - supplemental environmental impact statement

SEMP - Socioeconomic Monitoring Program

SESP - Social and Economic Studies Program

SLC - (California) State Lands Commission

SoCal - Southem California Gas Company

SOF - Suspension of Production

STEP - Sensitive Tract Evaluation Process

SWEPI - Shell Western Exploration \& Production, Inc.

SYU - Santa Ynez Unit

$T$

TA\&R - Technology Assessment and Research Program

Tcf - trillion cubic feet

TLWP - tension-leg well platform

TOC - total organic carbon

TSS - traffic separation scheme 


\section{English-Metric Conversion}

Measurements in this document are reported in the format that reflects the most common usage. The following table provides the factors for converting measurements to either U.S. Customary units or the International System (SI) of metric units.

\begin{tabular}{|c|c|}
\hline U.S. Customary unit & (multiply by to obtain) \\
\hline inches ............. & $\ldots \ldots \ldots$. . . . centimeters \\
\hline feet $\ldots \ldots \ldots \ldots \ldots$ & $\ldots \ldots .3048 \ldots \ldots \ldots$. . . . meters \\
\hline statute miles $\ldots \ldots \ldots \ldots$ & $\ldots .609$ \\
\hline nautical (geographic) miles .... & $\ldots \ldots 1.852 \ldots \ldots$. . . . . . . . . . . \\
\hline acres .... & $\ldots . . . \ldots .4047 \ldots$ hectares \\
\hline barrels (petroleum, $1 \mathrm{bbl}=42 \mathrm{gal}$ ) & $\ldots . .0 .15897 \ldots \ldots$ cubic meter \\
\hline gaillons $\ldots \ldots \ldots \ldots$. & $\ldots \ldots . . . .$. liters \\
\hline cubic feet ......... & $\ldots .0 .02832 \ldots$ \\
\hline tons, long (deadweight, $2,240 \mathrm{lb}$ ). & .... metric tons \\
\hline SI Metric unit & (multiply by to obtain) U.S. Customary unit \\
\hline centimeters & $\ldots . .0 .3937$ \\
\hline meters. & $\ldots .3 .281$ \\
\hline kilometers & . . miles, statute \\
\hline kilometers & ... miles, geographic (nautical) \\
\hline hectares. . & $\ldots .47105 \ldots$ \\
\hline cubic meters & $\ldots$ barrels (petroleum, $1 \mathrm{bbl}=42 \mathrm{gal}$ ) \\
\hline liters . . . . . . . . & $\ldots . . .$. \\
\hline metric tons $\ldots \ldots$ & . . . . . tons, long (deadweight, 2,240 lb) \\
\hline
\end{tabular}

NOTE: Distances on the lederal Outer Continental Sheif and on land are measured in statule miles.

Distances on the offshore State lands are measured in nautical (geographic) miles.

Generally, coastal States uere granted jurisdiction over of fhore lands to a distance of 3 natulical miles

from their coasts by the Submerged l.ands ACL 143 L.S.C. 1301, et seq.). The off shore jurisdiction of

Texas and Florida (on its gulf coast side only) extends to 3 marine leagues (approximately 10.35 statute miles)

for historic reasons 


\section{Contents}

Preface ....................... . . . . . .

Abbreviations and Acronyms $\ldots \ldots \ldots \ldots \ldots \ldots$ iv

English-Metric Conversion . . . . . . . . . . . . . . vi

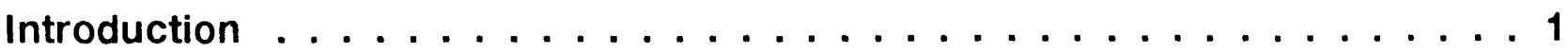

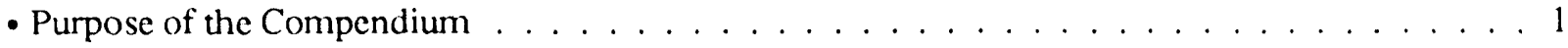

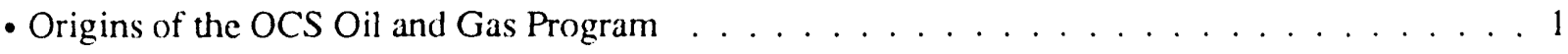

- Importance of the OCS Oil and Gas Program . . . . . . . . . . . . . . . . . 3

1. OCS Regional Geology, Petroleum Potential, and Resource Estimates . . . 7

- Alaska OCS Region . . . . . . . . . . . . . . . . . . . . . . . .

- Geology and Petrolcum Potential of the Alaska OCS Region . . . . . . . . . . . . . 7

Gulf of Alaska Planning Area . . . . . . . . . . . . . . . . . . . 7

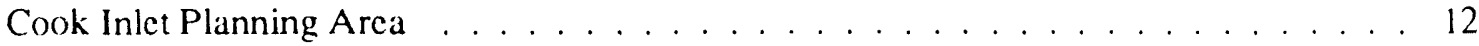

Kodiak Planning Area . . . . . . . . . . . . . . . . . . . 13

Shumagin Planning Area . . . . . . . . . . . . . . . . . . . . . 15

North Aleutian Basin Planning Area . . . . . . . . . . . . . . . . . . . 16

St. George Basin Planning Area . . . . . . . . . . . . . . . . . . . . . . . . 17

Aleutian Basin, Bowers Basin, and Aleutian Arc Planning Areas . . . . . . . . . . . . 19

St. Matthew-Hall Basin Planning Area . . . . . . . . . . . . . . . . . 20

Norton Basin Planning Area . . . . . . . . . . . . . . . . . . . . . 21

Navarin Basin Planning Area . . . . . . . . . . . . . . . . . . . 22

Hope Basin Planning Area . . . . . . . . . . . . . . . . . . . . . . . . . . . . 24

Chukchi Sea Planning Area . . . . . . . . . . . . . . . . . . . . . 25

Beaufort Sea Planning Area . . . . . . . . . . . . . . . . . . . . . . . 27

- Resource Estimates for the Alaska OCS Region . . . . . . . . . . . . . . . . . . . . . 30

- Atlantic OCS Region . . . . . . . . . . . . . . . . . . . . . . . . . . . 30

- Geology and Petroleum Potential of the Atlantic OCS Region . . . . . . . . . . . . . . . . 30

North Atlantic Planning Arca . . . . . . . . . . . . . . . . . . . . . . . . . . . 30

Mid-Atlantic Planning Arca . . . . . . . . . . . . . . . . . . 35

South Atlantic Planning Area $\ldots \ldots \ldots \ldots$

Straits of Florida Planning Area . . . . . . . . . . . . . . . . . . . . . . . 37

- Resource Estimates for the Atlantic OCS Region . . . . . . . . . . . . . 38

- Gulf of Mexico OCS Region . . . . . . . . . . . . . . . . . . . . . . . . 38

- Geology and Petrolcum Potential of the Gulf of Mexico Region . . . . . . . . . . . . . . 38

Eastern Gulf of Mexico Planning Area . . . . . . . . . . . . . . . . . . . . . . . . 38

Central Gulf of Mexics Planning Area . . . . . . . . . . . . . . . . . . . . . . . 43

Western Gulf of Mexico Planning Area . . . . . . . . . . . . . . . . . . . . 45

- Resource Estimates for the Gulf of Mexico OCS Region . . . . . . . . . . . . . . . . . 4h

- Pacific OCS Region . . . . . . . . . . . . . . . . . . . . . . . 46

- Geology and Petroleum Potential of the Pacific OCS Region . . . . . . . . . . . . . . 46

Southern Califormia Planning Area . . . . . . . . . . . . . . . . . 46 


\section{Contents}

- Pacific OCS Region (continued)

Central California Planning Area $\ldots \ldots \ldots \ldots \ldots$. . . . . . . . . . . . . . . .

Northern California Planning Area $\ldots \ldots \ldots \ldots \ldots \ldots \ldots$

Washington-Oregon Planning Area . . . . . . . . . . . . . . . . . . 53

- Resource Estimates of the Pacific OCS Region . . . . . . . . . . . . . . . . . . . 55

2. OCS Oil and Gas Leasing Program . . . . . . . . . . . . . . . . . 57

- Lease Sale Process . . . . . . . . . . . . . . . . . . . . . . 57

- Five-Year OCS Oil and Gas Leasing Program . . . . . . . . . . . . . . . . . . . . 57

- Draft Supplement to the Final Environmental Impact Statement . . . . . . . . . . . . . 60

- Development of the 5-year OCS Oil and Gas Leasing Program . . . . . . . . . . . . . . 61

- Presidential OCS Task Force . . . . . . . . . . . . . . . . . . . . 62

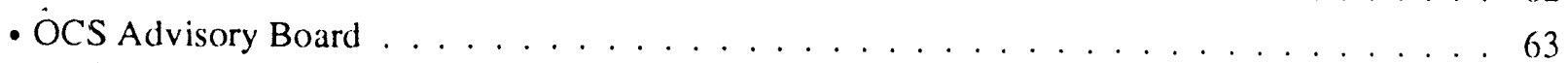

- OCS Policy Committee . . . . . . . . . . . . . . . . . . . . . . 63

- OCS Scientific Committec . . . . . . . . . . . . . . . . . . . . . . 65

- Regional Technical Working Groups . . . . . . . . . . . . . . . . . . . 65

- National Overview of OCS Leasing . . . . . . . . . . . . . . . . . . . 66

- Alaska OCS Region . . . . . . . . . . . . . . . . . . . . . . . . 67

- Atlantic OCS Region . . . . . . . . . . . . . . . . . . . . . . . . . 71

- Gulf of Mexico OCS Region . . . . . . . . . . . . . . . . . . . . . . . . . . . . 74

- Pacific OCS Region . . . . . . . . . . . . . . . . . . . . . . . . . . . . . 77

- Recent Lease Relinquishments . . . . . . . . . . . . . . . . . . . . . . . . 80

- Environmental Studies Program . . . . . . . . . . . . . . . . . . . . 80

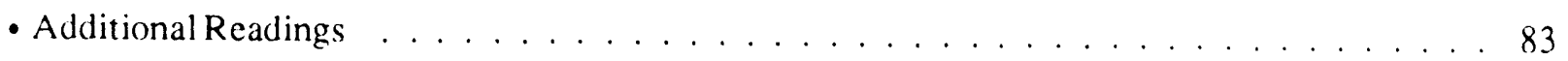

3. Postlease Activities on the OCS . . . . . . . . . . . . . . . . . 85

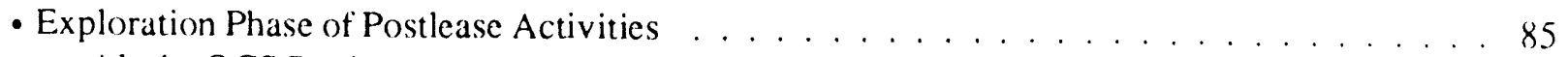

- Alaska OCS Region . . . . . . . . . . . . . . . . . . . . . . . 88

Klondike Prospect $\ldots \ldots \ldots \ldots$

Burger Prospect . . . . . . . . . . . . . . . . . . . . . . . . . . . . 95

Popcom Prospect . . . . . . . . . . . . . . . . . . . . . . . . . . . . . . . . . . . . 95

Crackerjack Prospect . . . . . . . . . . . . . . . . . . . . . . . . . . 95

Other Recent Exploration Activity . . . . . . . . . . . . . . . . . . . . . . . . . . . . . . . 96

Bowhead Whale Monitoring Program . . . . . . . . . . . . . . . . . . . . 96

- Atlantic OCS Region . . . . . . . . . . . . . . . . . . . . . . . . . . . . . . . 97

Mobil Oil Company Manteo Exploration Well Offshore North Carolina . . . . . . . . . . . l()()

- Gulf of Mexico OCS Region . . . . . . . . . . . . . . . . . . . . . . . . . 1(1)

- Pacific OCS Region . . . . . . . . . . . . . . . . . . . . . . . . . . . . . . . . . $1(1)$

- Development Phase of Postlease Activities . . . . . . . . . . . . . . . 110

- Alaska OCS Region . . . . . . . . . . . . . . . . . . . . . . . . . . . . . .

- Atlantic OCS Region . . . . . . . . . . . . . . . . . . . . . . . . . . . 110

- Gulf of Mexico OCS Region . . . . . . . . . . . . . . . . . . . . 110

- Pacific OCS Region . . . . . . . . . . . . . . . . . . . . . . . 118

Point Arguello and Gaviota Interim Marine Terminal . . . . . . . . . . . . . . . . . . . . . 118 


\section{continued}

Santa Ynez Unit and Las Flores Canyon . . . . . . . . . . . . . . . . . . 121

Point Pedernales Unit and Lompoc . . . . . . . . . . . . . . . . . . . . . 123

San Miguel and South Nipomo Mesa . . . . . . . . . . . . . . . . . . . 124

Santa Clara Unit . . . . . . . . . . . . . . . . . . . . . . 124

Cavern Point Unit . . . . . . . . . . . . . . . . . . . . 125

- Production Phase of Postlease Activities . . . . . . . . . . . . . . . . 125

- Gulf of Mexico Region . . . . . . . . . . . . . . . . . . . . . 128

- Pacific OCS Region . . . . . . . . . . . . . . . . . . . . 132

. Additional Reading . . . . . . . . . . . . . . . . . . . 134

4. Oil and Gas Transportation and Onshore Support Facilities . . . . . . . 137

. Oil and Gas Transportation . . . . . . . . . . . . . . . . . . . . . . 137

- Port Access Route Studies . . . . . . . . . . . . . . . . . . . . . . 137

- Regional Transportation Overviews . . . . . . . . . . . . . . . . . . 138

Alaska OCS Region . . . . . . . . . . . . . . . . . . . . . . . . . 138

Atlantic OCS Region . . . . . . . . . . . . . . . . . . . . . . . . 139

Gulf of Mexico OCS Region . . . . . . . . . . . . . . . . . . . . . . . 141

Pacific OCS Region . . . . . . . . . . . . . . . . . . . . . 143

- Onshore Support Facilities . . . . . . . . . . . . . . . . . . . . . 144

Alaska OCS Region . . . . . . . . . . . . . . . . . . . . 146

Atlantic OCS Region . . . . . . . . . . . . . . . . . . . . . 146

Gulf of Mexico OCS Region . . . . . . . . . . . . . . . . . . . . . . . . 148

Pacific OCS Region . . . . . . . . . . . . . . . . . . . 150

. Additional Readings . . . . . . . . . . . . . . . . . . . 151

5. Special Topics Related to the OCS Program . . . . . . . . . . . . . . 153

- Offshore Strategic and International Minerals Program . . . . . . . . . . . . 153

- Coastal Zone Management Program . . . . . . . . . . . . . . . . . . 157

- Coastal Zone Management Act Reauthorization . . . . . . . . . . . . . . . . . . . 157

- Consistency Certifications - Recent and Pending . . . . . . . . . . . . . 158

Recent Consistency Appeal Decisions . . . . . . . . . . . . . . . . . . . . 158

Pending Consistency Certification Appeals . . . . . . . . . . . . . . . . 159

- Rigs-to-Reefs Program . . . . . . . . . . . . . . . . . . . 160

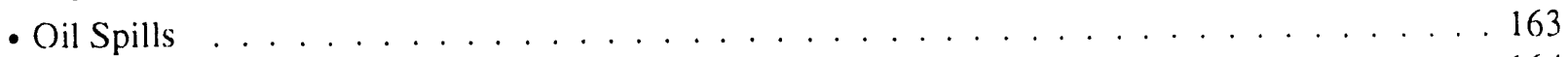

- Federal Oil-Spill Control and Cleanup Mechanisms . . . . . . . . . . . . . . . 164

- Federal Oil-Spill Research Programs . . . . . . . . . . . . . . . . . . . . 164

- Oil and Hazardous Materials Simulated Environmental Test Tank . . . . . . . . . . . 165

- Technology Assessment \& Research Program . . . . . . . . . . . . . . . . . . 165

- Oil Industry Oil-Spill Cooperatives . . . . . . . . . . . . . . . . . 165

- Oil-Spill Legislation and Recommendations . . . . . . . . . . . . . . . . . . . . 165

- Federal Comprehensive Oil Pollution Act of 1990 . . . . . . . . . . . . . . . 165

- Regional/International Oil-Spill Legislation . . . . . . . . . . . . . . . 166

- State Oil-Spill Legislation . . . . . . . . . . . . . . . . . . . . 166 


\section{Contents}

- Oil-Spill Legislation and Recommendations (continued)

- County Oil-Spill Legislation . . . . . . . . . . . . . . . . . . . . . 168

. Additional Readings . . . . . . . . . . . . . . . . . . 168

Appendix A: Bibliography of OCS Information Reports . . . . . . . . . 169

-Alaska Region . . . . . . . . . . . . . . . . . . . . . . . . . . . . 169

- Arctic Subregion Summary Reports and Updates . . . . . . . . . . . . . . . . . . . . . . 169

- Bering Sea Subregion Summary Reports and Updates . . . . . . . . . . . . . . . . . . . . . . . 169

- Gulf of Alaska Subregion Summary Reports and Updates . . . . . . . . . . . . . . . . . . 169

- Regionwide Alaska Summary Reports and Updates . . . . . . . . . . . . . . . . . . . . . 170

.. Alaska Indexes . . . . . . . . . . . . . . . . . . . . . . . . . . 170

- Alaska Summary/Index . . . . . . . . . . . . . . . . . . . . . 170

-Atlantic Region . . . . . . . . . . . . . . . . . . . . . . . . . . 170

- North Atlantic Summary Reports and Updates . . . . . . . . . . . . . . . . . . . . . . . . 170)

- Mid-Atlantic Summary Reports and Updates . . . . . . . . . . . . . . . . . . . . . . . 170

- South Atlantic Summary Reports and Updates . . . . . . . . . . . . . . . . . . . . . . 170

- Regionwide Atlantic Summary Report . . . . . . . . . . . . . . . . . . . . . . . 171

- Atlantic Indexes . . . . . . . . . . . . . . . . . . . . . . . . . 171

- Atlantic Summary/Index . . . . . . . . . . . . . . . . . . . . 171

- Gulf of Mexico Region . . . . . . . . . . . . . . . . . . . . . . . . 171

- Gulf of Mexico Summary Reports and Updates . . . . . . . . . . . . . . . . . . . 171

- Gulf of Mexico Indexes . . . . . . . . . . . . . . . . . . . . . . . 171

. Pacific Region . . . . . . . . . . . . . . . . . . . . . . . . . . . . . 172

- Pacific Summary Reports and Updates . . . . . . . . . . . . . . . . . . . . . . . 172

- Pacific Indexes . . . . . . . . . . . . . . . . . . . . . . . . 172

- Pacific Summary Index . . . . . . . . . . . . . . . . . . . . . . 172

- National . . . . . . . . . . . . . . . . . . . . . . . . . . . 172

- Other Documents of Interest . . . . . . . . . . . . . . . . . . . . . 173

- Other Items of Interest $\ldots \ldots \ldots \ldots$

Appendix B. Geologic Reports Available from MMS . . . . . . . . . . . . . 175

OCS Information Program Publication Staff $\ldots \ldots \ldots$. . . . . . . . . . .

\section{Figures}

\section{Introduction:}

1-1. Comparison of U.S. Crude oil consumption, imports, and price from 197() through 1989

1-2. Sources of crude oil for U.S. consumption for selected years $\ldots \ldots \ldots \ldots \ldots$

\section{Chapter 1:}

1-1. Geologic and gerophysical permits approved by MMS, 1969-89 . . . . . . . . . . . 9 


\section{continued}

1-2. Alaska OCS Region planning areas, basins, and depocenters _ . . . . . . . . . . . . 10

1-3. Atlantic OCS Region planning areas, basins, and depocenters . . . . . . . . . . . . . . . 33

1-4. Gulf of Mexico OCS Region planning areas, basins, and depocenters . . . . . . . . . . . . 40

1-5. Gulf of Mexico OCS Region planning areas and structural features . . . . . . . . . . . . . 41

1-6. Pacific OCS Region planning areas, basins, and depocenters . . . . . . . . . . . . 48

\section{Chapter 2:}

2-1. The prelease phase of the OCS oil and gas leasing process $\ldots \ldots \ldots$

2-2. Acres leased under tract selection, areawide, and focused leasing programs,

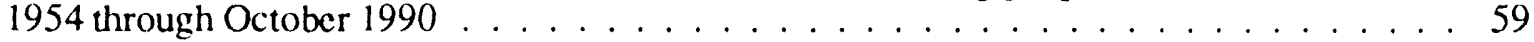

2-3. OCS Advisory Board structure . . . . . . . . . . . . . . . . . . . . . . . 64

2-4. Number of sales held, acres, leased, and high bonus bicis accepted by OCS region, 1954 October $31,1990 \ldots \ldots \ldots$. . . . . . . . . . . 66

$2-5$. Existing leases by OCS region as of October $31,1990 \ldots \ldots \ldots 6$

2-6. Comparison of oil price and high bonus bid accepted, 1954-89 . . . . . . . . . . . 66

2-7. Top 10 Alaska OCS leaseholders by percentages of acreage held

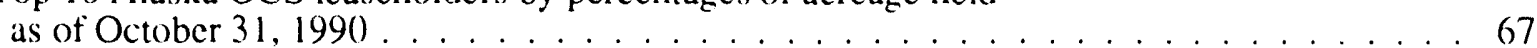

2-8. Top Atlantic OCS leaseholders by percentage of acreage held

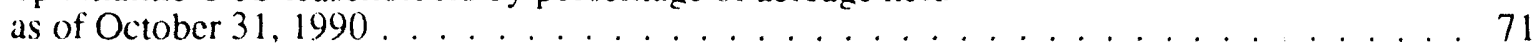

2-9. Major Gulf of Mexico OCS leascholders by percentage of acreage held

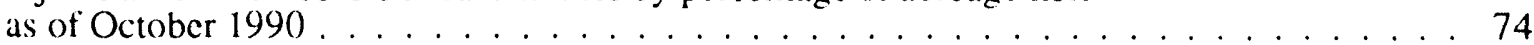

2-10. Top 10 Pacific OCS leaseholders by percentage of acreage hold

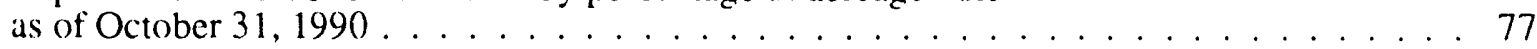

2-11. OCS Environmental Studies Program annual level of funding received

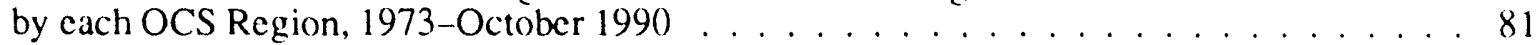

2-12. Percentage of OCS Environmental Studies Program funds distributed

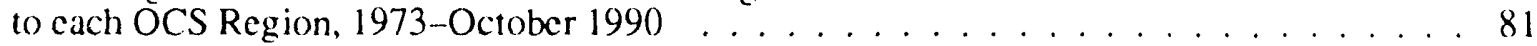

2-13. Expenditures, by discipline, for the OCS Environmental Studies Program,

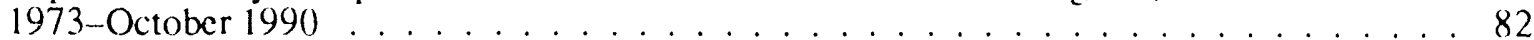

\section{Chapter 3:}

3-1. Postlease phase from lease issuance through the exploration, development, and production phases to the relinquishment of a lease . . . . . . . . . . . . . 86

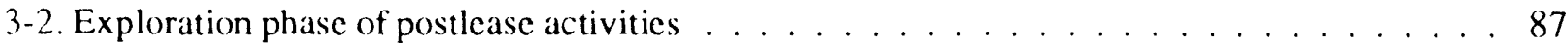

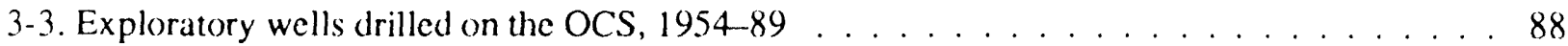

3-4. Exploratory wells drilled in the Alaska OCS Region by planning area,

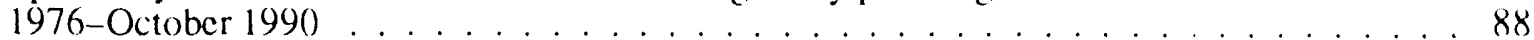

3-5. Alaska OCS region official protraction diagram locations . . . . . . . . . . . 91

3-6. Exploratory wells drilled in the Atlantic OCS Region by planning area, January $1,197 x$-October $31,1990 \ldots \ldots \ldots$. . . . . . . . . . . . . . . . . . . . . .

3-7. Atlantic OCS Region official protraction diagram locations . . . . . . . . . . . . . . 999

3-x. Total exploratory wells drilled in the Gulf of Mexico OCS Region by planning area and lease sale through October 31, 199(). 


\section{Contents}

3-9. Percentage of exploratory wells drilled, by year, in the Gulf of Mexico

OCS Region, 1954-89 . . . . . . . . . . . . . . . . . . . . . . . 104

3-10. Exploratory wells drilled, by year, in the Gulf of Mexico OCS Region, 1954-89 . . . . . 104

3-11. Exploratory wells drilled in the Pacific OCS Region by planning area, 1963-October 31,1990 . . . . . . . . . . . . . . . . . . . 107

3-12. Pacific OCS Region official protraction diagram locations . . . . . . . . . . . . . . . 109

3-13. Development and production phase of postlease activities $\ldots \ldots \ldots \ldots \ldots$

3-14. Total number of development wells drilled in the Gulf of Mexico OCS R.egion,

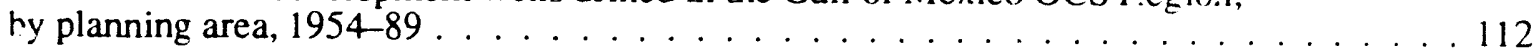

3-15. Gulf of Mexico OCS Region official protraction diagram locations . . . . . . . . . . 114

3-16. Gulf of Mexico OCS Region leasing maps . . . . . . . . . . . . . . . . . . 115

3-17. Number of development wells drilled in the Pacific OCS Region,

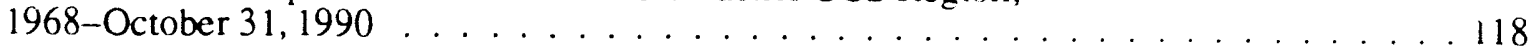

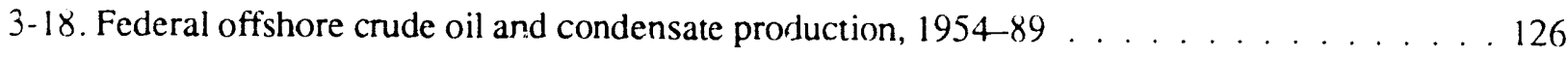

3-19. Federal offshore crudie oil and condensate production as a percentage

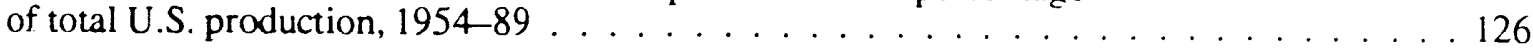

3-20. Top 10 producers by percentage of oil and condensate from the

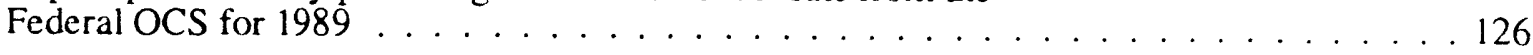

3-21. Federal offshore natural gas production, $1954-89 \ldots \ldots \ldots \ldots$

3-22. Federal offshore natural gas production as a percentage of total U.S. production, $1954-89 \ldots \ldots \ldots \ldots \ldots \ldots$. . . . . . . . . . . . . . . . . . . . . . . .

3-23. Top 10 producers by percentage of natural gas from the Federal OCS for $1989 \ldots \ldots 127$

3-24. National OCS oil and condensate production, 1954-89, showing relative amounts produced in the Gulf of Mexico and Pacific OCS Regions . . . . . . . . . . . . 128

3-25. National OCS gas production, 1954-89, showing relative amounts produced in the Gulf of Mexico and Pacific OCS Regions . . . . . . . . . . . . . . . 128

3-26. Number of proved fields and remaining recoverable reserves in the Ceritral Gulf of Mexico, by area, as of December 31, 1989

3-27. Numher of proved fields and renaining recoverable reserves in the Western Gulf of Mexico, by area, as of December 31, $1989 \ldots \ldots$. . . . . . . . . . . . 130

3-28. Crude oil and condensare production in the Gulf of Mexico OCS Region, 1954-89

3-29. Natural gas production in the Gulf of Mexico OCS Region, 1954-89 . . . . . . . . 130

3-30. Crude oil production in the Pacific OCS Region, 1968-89 . . . . . . . . . . . 133

3-31. Natural gas production in the Pacific DCS Region, 1968-89 . . . . . . . . . . 133

3-32. Recognized discoveries of federally controlled oil and gas fields in the Pacific OCS

\section{Chapter 4:}

41. Pipeline projects approved by MMS and total mileage, 1983-89 . . . . . . . . . 142

42. Offshore pipeline ronstruction from sites originating in the Pacific OCS Region, 1967-89

43. U.S. refining capacity, 1985-90 


\section{continued}

47. Design capacity, throughput, and number of shutdown coastal oil refineries in the Gulf of Mexico OCS Region, by State, as of January 1, 1990

45. Gulf of Mexico regional area gas processing capacity and throughput compared with all other States, as of January 1, 1990

\section{Chapter 5:}

$5-1$. OCS hard minerals area locations . . . . . . . . . . . . . . . . . 154

5-2. Yearly installations and removals of offshore production platforms on the Gulf of Mexico OCS, 1953-89

\section{Tables}

\section{Chapter 1:}

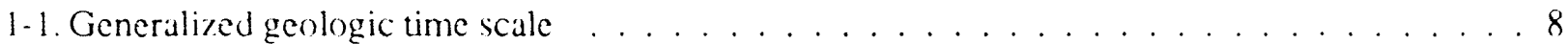

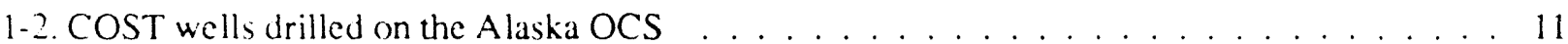

1-3. Estimates of undiscovered economically recoverable oil and gas resources in the Alaska OCS Region as of January $1990 \ldots \ldots$. . . . . . . . . . . . . . . . . . . . . . .

$1-4$. COST wells drilled on the Atlantic OCS . . . . . . . . . . . . . . . . . . . . . 34

1-5. Estimates of undiscovered economically recoverable oil and gas resources in the Atlantic OCS Region as of January $1990 \ldots \ldots$. . . . . . . . . . . . . . . 39

1-6. COST wells drilled on the Gulf of Mexico OCS . . . . . . . . . . . . . . . . 42

1-7. Estimates of undiscovered economically recoverable oil and gas resources in the Gulf of Mexico OCS Region as of January $1990 \ldots \ldots$. . . . . . . . . . . . . . . . . 47

$1-x$. COST wells drilled on the Pacific OCS . . . . . . . . . . . . . . . . . 50

1-9. Estimated undiscovered economically recoverable oil and gas resources in the Pacitic OCS Region as of January 1990 . . . . . . . . . . . . . . . . . . . . . . 56

\section{Chapter 2:}

2-1. Lease sale history of the Alaska OCS Region as of October 31, 1990 . . . . . . . . . 68

2-2. Dates of and Federal Register notices for significant prelease steps for proposed Alaska OCS lease sales from January 1987 through October 31, 1990 . . . . . . . . . 69

2-3. Alaska OCS Region lease sale stipulations . . . . . . . . . . . . . . . . . . 70

2-4. Dates of and Federal Register notices for significant prelease steps for

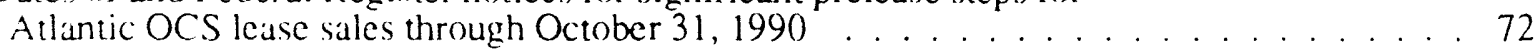

2-5. Lease sale history of the Atlantic OCS Region as of October 31, 1990 $\ldots \ldots$. . . . . . . 73

2-6. Lease sule history of the Gulf of Mexico OCS Region as of October 31, 1990 . . . . . . . . 75

2-7. Duter uf and Federal Register notice, for significant prelease steps for recent (jult it Mexico OCS lease sales through October 31, 1990 . . . . . . . . . . 76

2-4. Lewe sale hintury tor the Pacitic OCS Region as of October $31,1990 \ldots \ldots$. . . . . . . 78

2-9. Dater it and Federal Register notices for significant prelease steps for

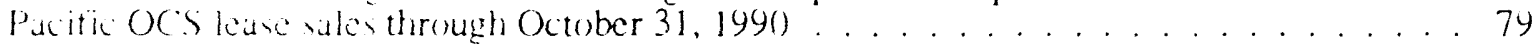




\section{Contents continued}

\section{Chapter 3:}

3-1. A laska OCS drilling history as of October $31,1990 \ldots \ldots$. . . . . . . . 89-90

3-2. Exploratory wells drilled in the Atlantic OCS Region by planning area and lease sale . . . . . . . . . . . . . . . . . . . . . . . . 98

3-3. Exploratory wells drilled in the Gulf of Mexico OCS Region, by planning area,

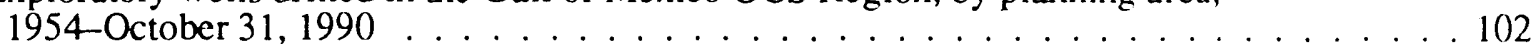

3-4. Exploratory wells drilled in the Eastern Gulf of Mexico OCS Planning area as of October $31,1990 \ldots \ldots \ldots \ldots$. . . . . . . . . . . . . . . . . . . . . . . . . . . . . .

3-5. Deep-water drilling activity in the Gulf of Mexico OCS Region, January $1,1989-$ October $31,1990 \ldots \ldots \ldots$. . . . . . . . . . . . . . . . . . . . . . .

3-6. Exploratory wells drilled in the Pacific OCS Region, by OPD location number,

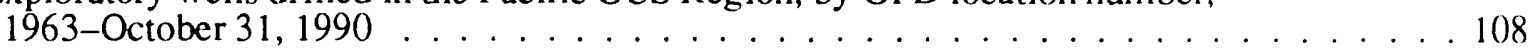

3-7. Total number of development wells drilled in the Gulf of Mexico OCS Region, by OPD/Leasing Map location, $1954-89 \ldots \ldots \ldots \ldots \ldots \ldots$

3-8. Selected Gulf of Mexico OCS Region decp-water projects as of October 31, 1990 . . . . . 117

3-9. Development wells drilled on the Pacific OCS as of October $31,1990 \ldots \ldots$

3-10. Platforms proposed to be installed in the Pacific OCS Region as of October 31, 1990.

3-11. Oil and gas reserves and cumulative production at end of year for the Gulf of Mexico outer continental shelf and slope, 1975-89

3-12. Estimated demonstrated oil and gas reserves for 739 fields in the Gulf of Mcxico OCS Region, by planning area, as of December $31,1989 \ldots \ldots$. . . . . . . . . . . 131

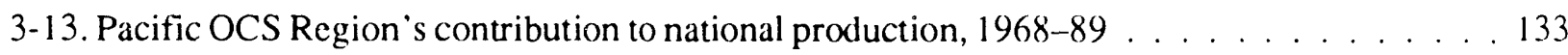

3-14. Estimated annual oil and gas reserves and cumulative production for the Pacific OCS Region, 1982-89.

\section{Chapter 4:}

41. Transportation scenarios for hydrocarbons produced from

42. Existing and proposed OCS pipelines offshore California as of October 31, $1989 \ldots 145$

43. Actual or potential A laska OCS Region support facilitics . . . . . . . . . . . . . . 147

44. Pacific Coast active refineries and their operable atmospheric crude oil distillation capacity on January $1,1987,1988$, and $1989 \ldots \ldots \ldots 2 \ldots \ldots \ldots \ldots$

\section{Chapter 5:}

5-1. Existing and permitted rigs-to-reefs projects on the Gulf of Mexico OCS through October 199()

\section{Timeline}




\section{Introduction}

\section{Purpose of the Compendium}

The Minerals Management Service's (MMS) Outer Continental Shelf Information Program (OCSIP) is responsible for making available to affected coastal States, local governments, and other interested parties data and information related to the Outer Continental Shelf (OCS) Oil and Gas Program. Since its establishment through Section 26 of the OCS Lands Act (OCSLA) Amendments of 1978, OCSIP has prepared regional summary reports, updates, and indexes on leasing, exploration, develop-ment, and production activities to fulfill the mandates of the OCSLA Amendments.

The OCSIP receives many requests for outof-print summary reports, updates, and indexes. The purpose of the OCS National Compendium is to consolidate these historical data and to present the data on an OCS-wide and regional scale. The single-volume approach allows the reader access to historical information and facilitates regional comparisons. The fold-out chart in the front of this publication provides the reader with a timeline (January 1988-

November 1990) of events since publication of the last Compendium. Some of these events are directly related to the 5-Year Oil and Gas Program, whereas others may or may not have an effect on the program. A predominantly graphic format is used in the report so that the large accumulation of data can be more readily comprehended. In some cases, it is not possible to update information through October 31 , 1990, because of the nature of the data. For example, production data normally lags 3 months.

\section{Origins of the OCS Oil and Gas Program}

Offshore oil and gas production dates back to 1897, when enterprising operators in Summerland, California, built piers into the Pacific Ocean to further develop coastal oil fields. For the next three decades, offshore oil development occurred along the California and Gulf of Mexico coasts from wharves or pilings. Some drilling from floating barges occurred in very shallow inland waters offshore of Louisiana. It became apparent to onshore operators in Louisiana and Texas that a strong possibility of substantial offshore reserves existed. Operators gradually moved farther offshore into deeper waters, but were still constrained by using timber pilings to support the drilling platform. By 1940, the British American Oil Company had made a discovery 2 miles offshore of Louisiana in 17 feet of water from a piling-supported platform. In August 1945, the State of Louisiana held an offshore lease sale, where about 89,000 acres were sold for an average of $\$ 5.13$ per acre. Steel pilings were introduced in 1946 to strengthen platforms in deeper waters.

The period from 1947 to 1953 was one of jurisdictional controversy between the States and the Federal Government over ownership of submerged lands. The tidelands controversy caused an interruption in leasing and development of nearshore submerged lands during this period. In 1953, Congress passed the Submerged Lands Act, which granted the States the rights to the natural resources of submerged lands out to a distance of 3 geographic miles from each State's coastline. The Act also reaffirmed the Federal claim to the continental shelf seaward of State jurisdiction. In addition, 
this legislation set the stage for passage of the OCS Lands Act and subsequent leasing on the OCS the following year. This leasing hiatus resulted in increased competition for these offshore lands once leasing resumed.

The Department of the Interior's (DOI) OCS Oil and Gas Program began with the passage of the OCS Lands Act of 1953. The Act provided for the jurisdiction of the United States over the submerged lands of the OCS and authorized the Secretary of the Interior to lease such lands. Shortly after the passage of the Act, the first OCS lease sale was held in the Gulf of Mexico on October 13, 1954. The DOI leased 90 tracts and collected $\$ 116$ million in bonus payments from operators for the right to explore these leases.

During the next 24 years, the DOI held 41 offshore oil and gas lease sales, which resulted in the production of 4.6 billion barrels of oil (BBO). In 1978, the OCS Lands Act Amendments were enacted as a result of several findings by Congress, among which were the following:

- that domestic production of oil and gas had declined in recent years;

- that there was an increasing reliance of the United States upon imports of oil from foreign nations to meet domestic energy demand; and

- that the OCS contains significant quantities of oil and natural gas and is a vital national resource reserve that must be carefully managed so as to realize fair market value (P.L. 95-372).

The purposes of the OCS Lands Act Amendments of 1978 are as follows:

- to establish policies and procedures to expedite development of OCS oil and gas resources;
- to preserve, protect, and develop oil and natural gas resources and to balance the orderly development of these resources with protection of the human, marine, and coastal environments;

- to encourage development of new technology;

- to provide States and local governments with comprehensive assistance in order to anticipate and plan for any impacts;

- to ensure that States and local governments have timely access to information;

- to ensure that those States and local governments that are directly affected have an opportunity to participate in policy and planning decisions relating to the management of OCS oil and gas resources;

- to minimize or eliminate conflicts between the development of hydrocarbon resources and the development of other resources such as fish;

- to establish an oil-spill-liability fund;

- to ensure that the extent of hydrocarbon resources is assessed at the earliest practicable time; and

- to establish a Fisherman's Contingency Fund to pay for damages to commercial fishing vessels and gear resulting from OCS activities.

Since enactment of this legislation, the Secretary of the Interior has implemented three 5-year leasing programs with the fourth 5-year program to be released in 1991. The 5-year program is discussed in more detail in Chapter 2 (p. 57). 


\section{Importance of the OCS Oil and Gas Program}

The Deparment of the Interior's OCS Oil and Gas Program has existed since 1954. The OCS has signiticant resourecs and reserves of both natural gas and crude oil. Industry 's interest in the OCS initially focused on the development of crude oil resources because the United States has primarily based its energy needs on this fuel. Crude oil was relatively easily obtained, casily transported, and contains substantial Btus in a relatively small volume. As the larger more easily discovered onshore ficlds were developed and subsequently matured, the OCS became the obvious choice for secking additional large crude oil reserves.

To appreciate the importance of the OCS Oil and Gis Program as part of the national energy market. it is necessary to examine four factors:

- the price of oil over time.

- the anmount of crude oil produced domestically,

- the amount of crude oil historically consumed by the United States, and

- the percentage of crude oil consumed that is imported from other countries.

The United States has been an oil producing nation for over 130 years and until 1974, when the Lnited States was surpassed by the Soviet C'nion. produced more oil per year than any other country in the world. In 1970) crude oil (c) $\$ 3.35$ per barrel on the average. U.S. petrokeum production peaked during this year at 11.3 million barrels per day ( $\mathrm{MMbpd}$ ), of which the federal OCS contributed 10 percent. Tonal l's. consumption of crude oil and related petroleum products for 1970 was $14.7 \mathrm{MMbpd}$. Tonal net imports of crude oil and related petroleum products at that time were $3.2 \mathrm{MMbpd}$. or about 22 percent of total consumption. Over 42 percent, or $1.3 \mathrm{MMbpd}$, of the crude sil and petroleum products imported were from the OrLanisation of Petroleum Exporting Countries
(OPEC). But only 14 percent of the 1.3 MMbpd was from Arab OPEC (Algeria, Iray, Kuwait, Libya, Qatar, Saudi Arabia, and United Arab Emirates). Figure I-1 (p. 4) compares the annual relationships of the price of West Texas Intermediate crude oil, U.S. consumption, and U.S. net imports. Figure I-2 (p. 5) displays the source of crude oil for U.S. consumption for the years highlighted in this discussion.

By 1977 , total U.S. production had dropped to $9.9 \mathrm{MMbpd}$, while the price of oil averaged $\$ 14.30$ per barrel. The Federal OCS was still contributing about 10 percent of the total. However, U.S. consumption had grown by 25 percent in just 7 years to $18.4 \mathrm{MMbpd}$. As a result of the decline in U.S. production and the increase in U.S. consumption, net importis had increased to almost 47 percent of consumption, and over 72 perent of the net imports were being supplied by OPEC. The Arab OPEC import percentage had risen from 14 percent to 52 percent. As mentioned in the previous section, in 1978 Congress recognized the degree to which the United States relied on imports, in particular the dramatic increase on Arab OPEC imports, and responded by passing the OCS Lands Act Amendments in an attempt to enhance domestic production and decrease the reliance on imported oil.

By the second quarter of 1980 , the price of oil was averaging $\$ 39.50$ per barrel. Domestic production had risen marginally to 10.2 MMbpd, of which about 9 percent was from the Federal OCS. United States consumption had fallen to 17.1 MMbpd. A number of factors contributed to the decrease in U.S. consumption by 1980 . Among these were the following:

- the dramatic increase in the price of sil curtailed unnecessary trips and vacation driving and promored car pooling and mass transit;

- energy effir:ancy in manufacturing processes and machinery was established: 


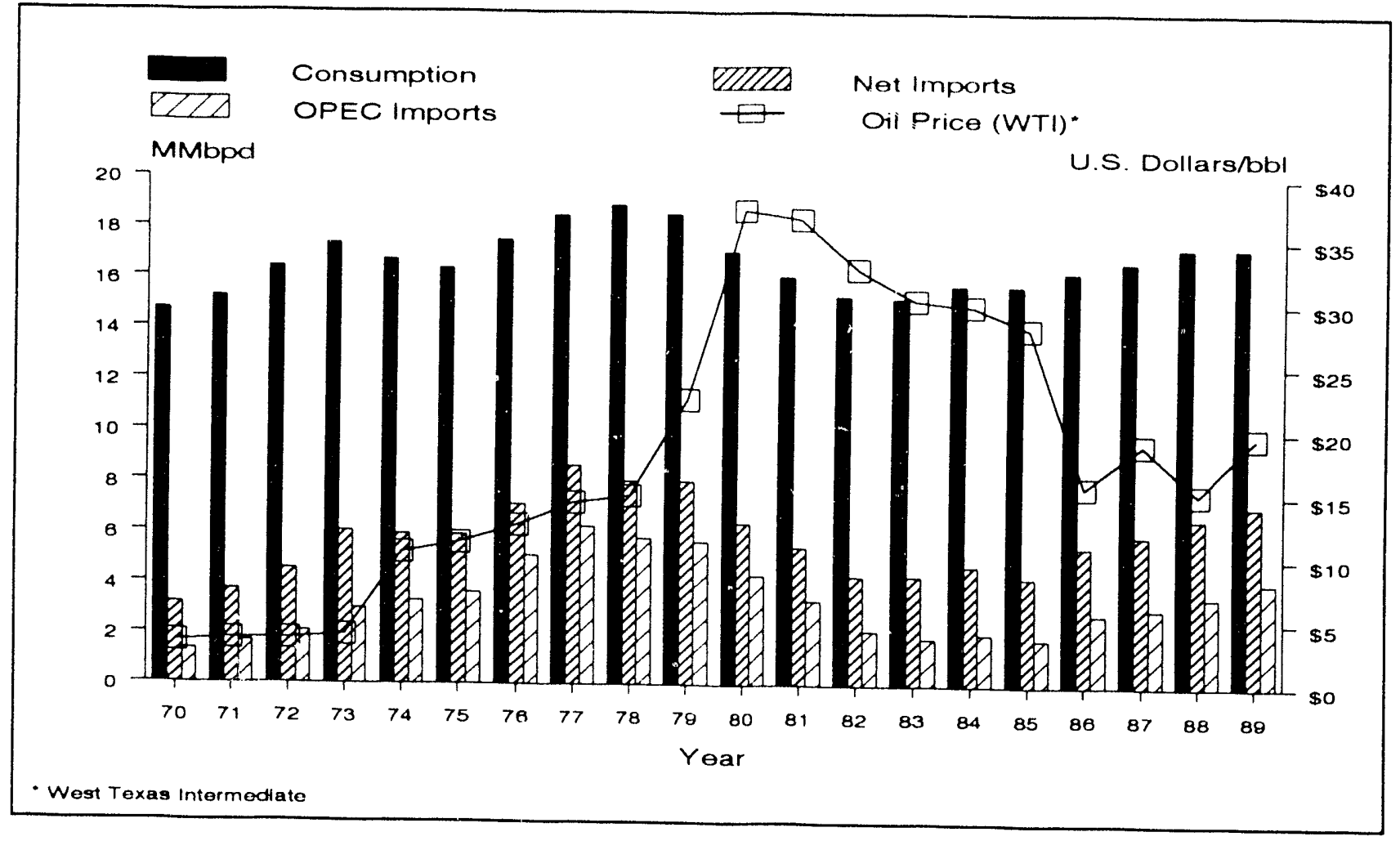

Figure I-1. Comparison of U.S. crude oil consumption, imports, and price from 1970 through 1989.

- conservation measures were practiced at many levels of society; and

\section{- conversions were made to other energy} sources, such as coal and natural gas.

These and other measures not only resulted in reduced U.S. consumption but consequently reduced imports, as well, to 37 percent of consumption. Nevertheless, 68 percent of imports were still being supplied by OPEC, and the Arab OPEC contribution had risen to 59 percent of total imports.

The price of oil gradually decreased until it reached about $\$ 28$ per barrel in 1985 . Domestic production rose slightly to $10.6 \mathrm{MMbpd}$. The Federal OCS contribution had risen to approximately 12 percent. Consumption had fallen further to $15.7 \mathrm{MMbpd}$, resulting in a substantial drop in net imports to 27 percent. The Arab OPEC contribution to total U.S. imports had dropped dramatically to 26 percent.
By 1989 , total production had again fallen to $9.2 \mathrm{MMbpd}$, a level roughly equivalent to the 1965 production level. The Federal OCS contribution to the U.S. total production declined by 85 million barrels of oil (MMBO) and represented about 11 percent of total U.S. production. While production declined, consumption grew by $1.5 \mathrm{MMbpd}$ to $17.2 \mathrm{MMbpd}$. Consequently, net U.S. imports were on the rise resulting in a doubling of both the OPEC share $(58$ percent) and the Arab OPEC share (52 percent). From 1970) through 1990, the Federal OCS contribution to total U.S. production has remained remarkedly constant.

With regards to the U.S. energy picture, OPEC has swung from a minor player to a major player more than a few times since the 1960's. Since the early 1960's, OPEC has exported substantial quantities of oil to countries other than the United States. In 197(), OPEC. exported to the United States and other countries over 20 MMbpd. As stated above, the 


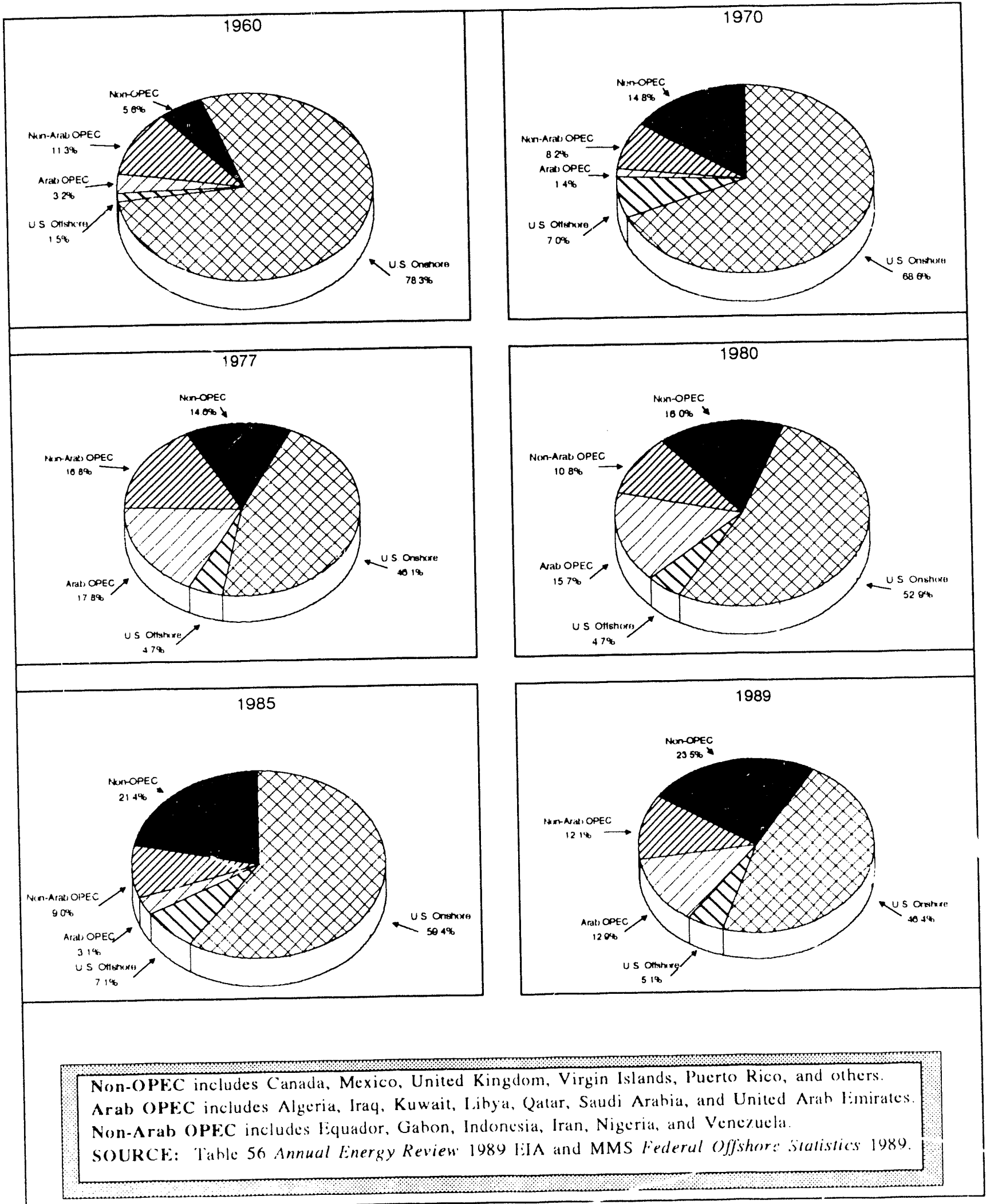

Figure 1-2. Sources of crude oil for L'S. consumption for selected years. [Note: Mexico's share of U.S imports grew from 3 percent in 1960 to 20 percent by $1989 \mathrm{or}$ the "non-OPEC" imports category.] 
U.S. portion of this was only $1.3 \mathrm{MMbpd}$. OPEC total exports grew to $27.6 \mathrm{MMbpd}$ by 1977. Worldwide conservation measures and substantial increases in production from other areas around the world, such as the North Sea, reduced OPEC exports to 22.8 MMbpd by 1980 and only $10.8 \mathrm{MMbpd}$ by 1985 . In only 8 years, OPEC total exports were reduced by over 60 percent. In an effort to regain its lost market share. OPEC abandoned its traditional role of residual market supplier and proceeded to produce more oil. This policy resulted in the oil price collapse of $198: 6$, which saw the price of oil plummet from $\$ 28$ per barrel in January to only $\$ 12$ per barrel by August. The next 2 years would see the price of oil increase to as much as $\$ 20$ per barrel and decrease to a low of $\$ 12.75$ per barrel near the end of 1988 . By the end of 1989 , the price of oil averaged $\$ 19.56$ per barrel and would continue near that level until August 1990.

The Iraqi invasion of Kuwait caused a series of wild price fluctuations that sometimes occurred daily. By mid-October 1990, the price of oil closed above $\$ 40$ per barrel on two days, and in fact, reached a record high of $\$ 41.15$ per barrel during the day of October 10th. But rumors that a peaceful settlement to the Persian Gulf crisis may be more likely dropped the price of oil over $\$ 11$ per barrel in a week.

Currently, the only known U.S. onshore large structures with hydrocarbon potential are located within the Coastal Piain of the Arctic National Wildlife Refuge on the North Slope of Alaska. Because of the legislation that created Liis refuge, an act of Congress would be necessary to permit oil and gas exploration and/or development to occur in this area. However, the Federal OCS is estimated to contain conditional undiscovered economically recovcrable petrolcum resources of 8.9 billion barrels of oil (BBO) in the mean case. (See ch. 1 for a more detailed discussion of OCS geology and resource estimates.) The significant potential of the Federal OCS as a secure petroleum resource, if developed, could reduce the U.S. dependence on imported oil, in par- ticular OPEC oil, and help to balance the U.S. trade deficit. Additionally, the DOI (through both the Bureau of Land Management and the MMS) has held 104 lease sales and collected over $\$ 55$ billion in bonuses and another $\$ 35.7$ billion in royalties and rentals since 1954 .

The offshore natural gas industry developed, as large volumes of gas were produced with oil or from separate gas reservoirs. The importance of gas has increased in recent years due, in part, to (1) declining domestic crude oil production, resulting in an increase in crude oil imports, and (2) the fact that the production and combustion of natural gas result in less pollution. Natural gas production on the OCS provides over 23 percent of the total U.S. natural gas production (see ch. 3 for more information on natural gas production). The Gulf of Mexico OCS Region is considered a worldclass producer of natural gas. The natural gas pipeline network, developed over the past 37 years, will help to bring this growing U.S. energy resource to markets that are currently using, or switching to, natural gas as their primary energy source.

As the demand for natural gas continues to grow, the United States will inventory for future use areas within the OCS that are considered to have high natural gas potential (e.g., the Atlantic OCS Region and deep-water areas of the Gulf of Mexico OCS Region). 


\section{OCS Regional Geology, Petroleum Potential, and Resource Estimates}

This chapter summarizes the geology, petroleum potential, and the resource and reserve estimates, for each of the planning areas within the four MMS Outer Continental Shelf (OCS) regions (Alaska, Atlantic, Gulf of Mexico, and Pacific).

The geology and petroleum potential summaries were provided by each of the OCS regional offices. A generalized geologic time scale is included for reference (sec table 1-1, p. 8).

The MMS resource estimates for each of the OCS planning areas are based, in part, on data from industry exploratory and development operations performed under permits or mineral leases issued for the Federal OCS. Figure 1-1 (p. 9) shows the number of geologic and geophysical permits approved by MMS from 1969 through 1989. (See the Geologic and Geophysical Permil Data sidebar (p. 8) for additional information.) These data were used to identify and map specific offshore prospects and also 10 extrapolate potential prospects where data gaps exist. Economic parameters were developed to incorporate oil and natural gas prices, development, production, and transportation costs, and future predictions for these and other cconomic factors that may influence industry "s development activities. Estimates of undiscovered cconomically recoverable oil and gas resources were developed using a computer mathematical simulation model, Probabilistic Resource Estimates - Otfshore, or PRESTO. (For a description of this model. ece ch. 2 of OCS Report MMS $89-1)(090)$. Estrmates of Undiscovered Oil \& Gas Resources for the Outer Continental Snclf as of 1987 available from the following address:

\author{
Document Distribution Center \\ Technical Communication Services \\ Minerals Management Service, MS 4530 \\ 381 Elden St. \\ Herndon, VA 22070-4817 \\ Telephone: (703) 787-1080.
}

\section{Alaska OCS Region}

The Alaska OCS Region is divided into 15 planning areas for the purpose of OCS oil and gas leasing. These areas, as well as the Alaska OCS Region basins and depocenters, are depicted in figure $1-2(\mathrm{p} .10)$.

\section{Geology and Petroleum Potential of the Alaska OCS Region}

\section{Gulf of Alaska Planning Area}

The Gulf of Alaska Planning Arca is located in the northeast comer of the Pacific Ocean and extends, in general, from Dixon Entrance at the U.S.-Canada border, across the gulf to the Kenai Peninsula. It is part of the Pacific Margin Tertiary Province. The planning area is divided into four physiographically distinctive segments. From east to west, the segments are as follows: the southeastern Alaska segment, from Dixon Entrance to Cross Sound; the Yakutat segment, from Cross Sound to Icy Bay; the Yakataga segment, from Icy Bay to Kayak Island; and the Middleton Island segment, from Kayak Island to the Amatuli Trough, southwest of Montague Island. However, the Middleton Island segment is actually in the Kodiak geologic province, and geological and geophysical data from this segment were used in the assessment of Kodiak. A discussion of the geology of the Middleton Island segment is also included in the Kodiak Planning Area summary. The continental slope and areas farther 
Table 1-1. Generalized geologic time scale

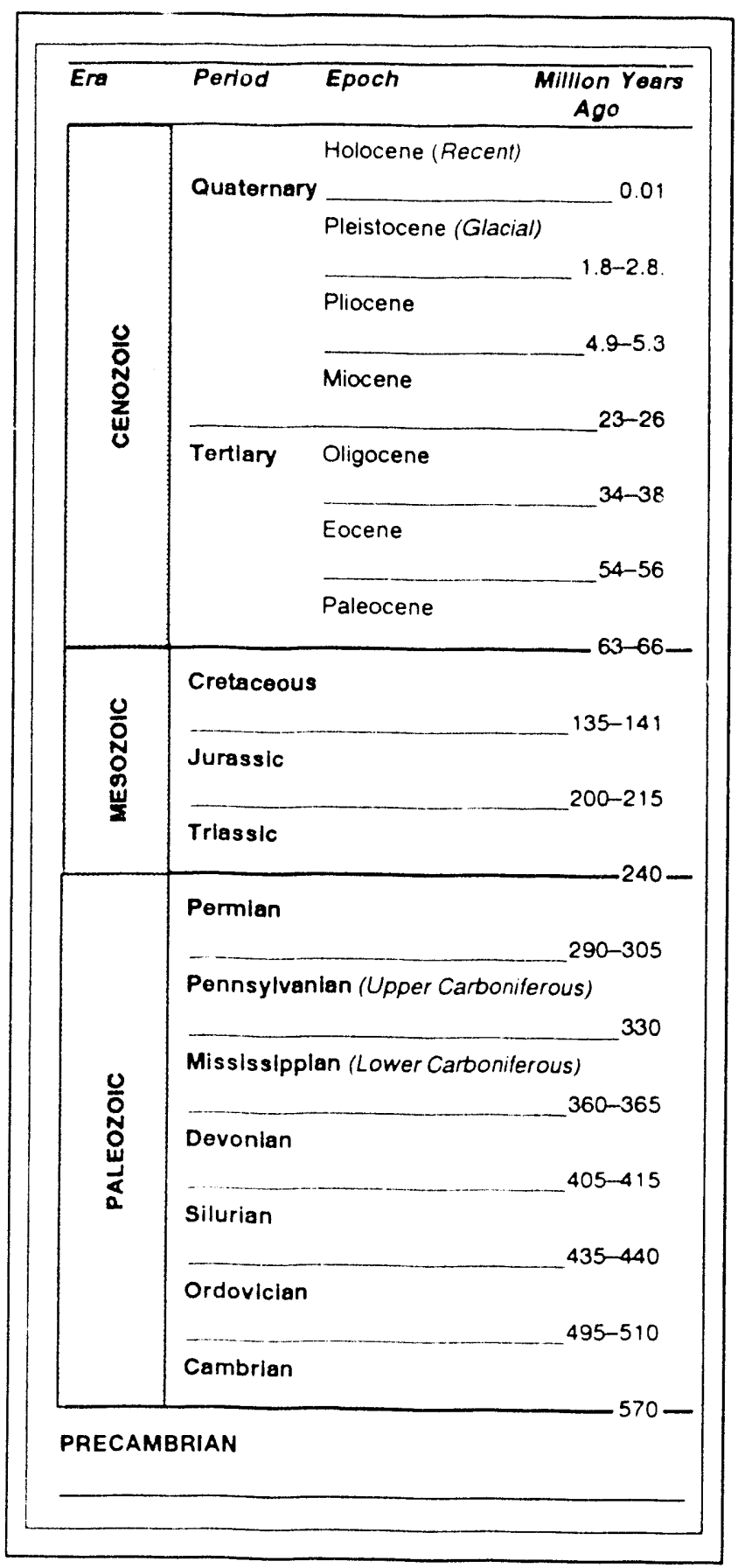

\section{Geological and Geophysical Data}

Geological and geophysical (G\&G) surveys and analyses provide most of the resource information used by government and industry on the oil and gas potential of offshore areas. The collecting of G\&G data begins prior to the leasing of Federal land and continues throughout the term of offshore mineral leases. Title 30, part 251, of the Code of Federal Regulations (CFR) contains the regulations regarding acquisition of $G \& G$ data and information on the OCS.The MM:s administers permitting and data acquisition through these regulations. The purpose of these regulations is to prescribe (1) when a permit or the filing of a notice is required to conduct G\&G exploration or sicientific research on the OCS, as well as the operating procedures for conducting these activities; (2) th.e disclosure of data and information; and (3) the ronditions for reimbursement of certain costs wher. MMS acquires such data and information.

Pernit applications for G\&G activity must be submitter to MMS in accordance with the requiremerts outlined in these regulations and explained iurther in Letter(s) to Permittees. The coastal States are not involved in the review process for spscific G\&G applications prior to issuance of the permit, except for deep stratigraphic tests (DST's). Environmental reports are required in accordance with 30 CFR 251.6-2(6) for DST's, and when required under a coastal zone management program, must receive state concurrence prior to approval of any activities covered under the permit. (See ch.5 for more information on the Coastal Zone Management Program.)

After receiving a $G \& G$ permit application. MMS either determines that the $G \& G$ activities are included under a categorical exclusion review (CER) or prepares an environmental assessment (EA) in accordance win the National Environmental Policy Act and other applicable MMS policies and regulations. Most $G \& G$ activities are included under a CER. Activities that (1) include the drilling of DST holes, (2) involve the use of solid or liquid explosives, or (3) have the potential to significantly affect the quality of the h.sman environment, require the preparation of an EA. 


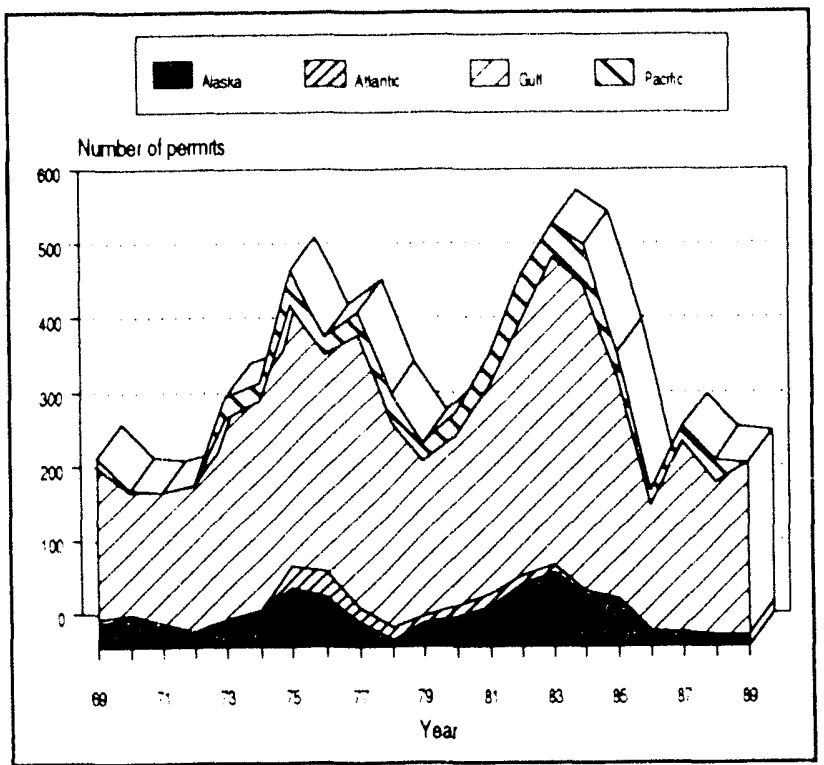

Figure 1-1. Geoiogic and geophysical permits approved by MMS, 1969-89.

offshore within the planning area comprise a separate low-potential segment. The planning area is underlain by Tertiary rocks consisting mostly of clastics with minor volcaniclastics and volcanics. These sediments are generally less than 5,000 feet $(1,500 \mathrm{~m})$ thick, but range locally up to 20,000 feet $(6,100 \mathrm{~m})$ in thickness in the southeast segment; up to 20,000 feet $(6,100 \mathrm{~m})$ in the Yakutat segment; from 10,000 feet $(3,000 \mathrm{~m})$ to over 32,000 feet $(9,800 \mathrm{~m})$ in the Yakataga segment; and up to 12,000 feet $(3,600 \mathrm{~m})$ in the Middleton segment east of Montague Island. West of Montague Island, sediment thickness is less than $5,(00)$ feet $(1,500$ $\mathrm{m})$.

Gulf of Alaska stratigraphy is dominated by four rock units:

- Mesozoic Yakutat Group.-This group consists of graywacke, argillite, slate, and minor conglomerate that crops out onshore in the Yakutat segment. It is generally considered to be economic and acoustic basement in the offshore of the eastern Yakutat segment.
- Kulthieth Formation.-Above the Yakutat Group is an undifferentiated Early Tertiary unit of sandstone and siltstone locally present in the Yakutat segment; and the Eocene Kulthicth Formation, consisting of deltaic deposits of mudstones, siltstones, and sandstones with minor coal, with its deep-water and associated volcanic equivalent, the Tokun Formation. The source potential of the Kulthieth is primarily gas, with subordinate potential for oil generation.

- Poul Creek Formation.-The late Eocene to early Miocene Poul Creek Formation, primarily mudstone and siltstone, overlies the Kulthieth Formation. It crops out onshore and was encountered in at least four offshore exploration wells (Y-0032, Y-0007, Y-0080, and $Y-0211$ ). (See ch. 3 for more information on exploratory drilling on the Alaska OCS).

- Yakataga Formation.-The late Miocene to Pleistocene Yakataga Formation is predominantly glacio-marine diamictites and interlayered mixtures of mudstone, siltstones, sandstones, and glacially derived sediments. The Yakataga Formation is the dominant section penetrated by exploratory wells drilled in the Yakataga segment of the Gulf. Thinner sections of Yakataga Formation were also encountered in the offshore Y-0211 (Yakutat) and Middleton Island exploratory wells.

Another unit, possibly equivalent to the Miocene-age Skonun Formation in British Columbia, contains turbidites, silts, and muds. This unit is restricted to the southeastern segment of the Gulf of Alaska Planning Area.

Offshore drilling began in the Gulf of Alaska in 1969 with the drilling of a single exploratory well in State waters off Middleton Island. Drilling hegan in the Federal planning area in 1975 with the completion of a COST well. (See table 1-2, p. 11, for a detailed list of the COST wells drilled on the Alaska OCS). 


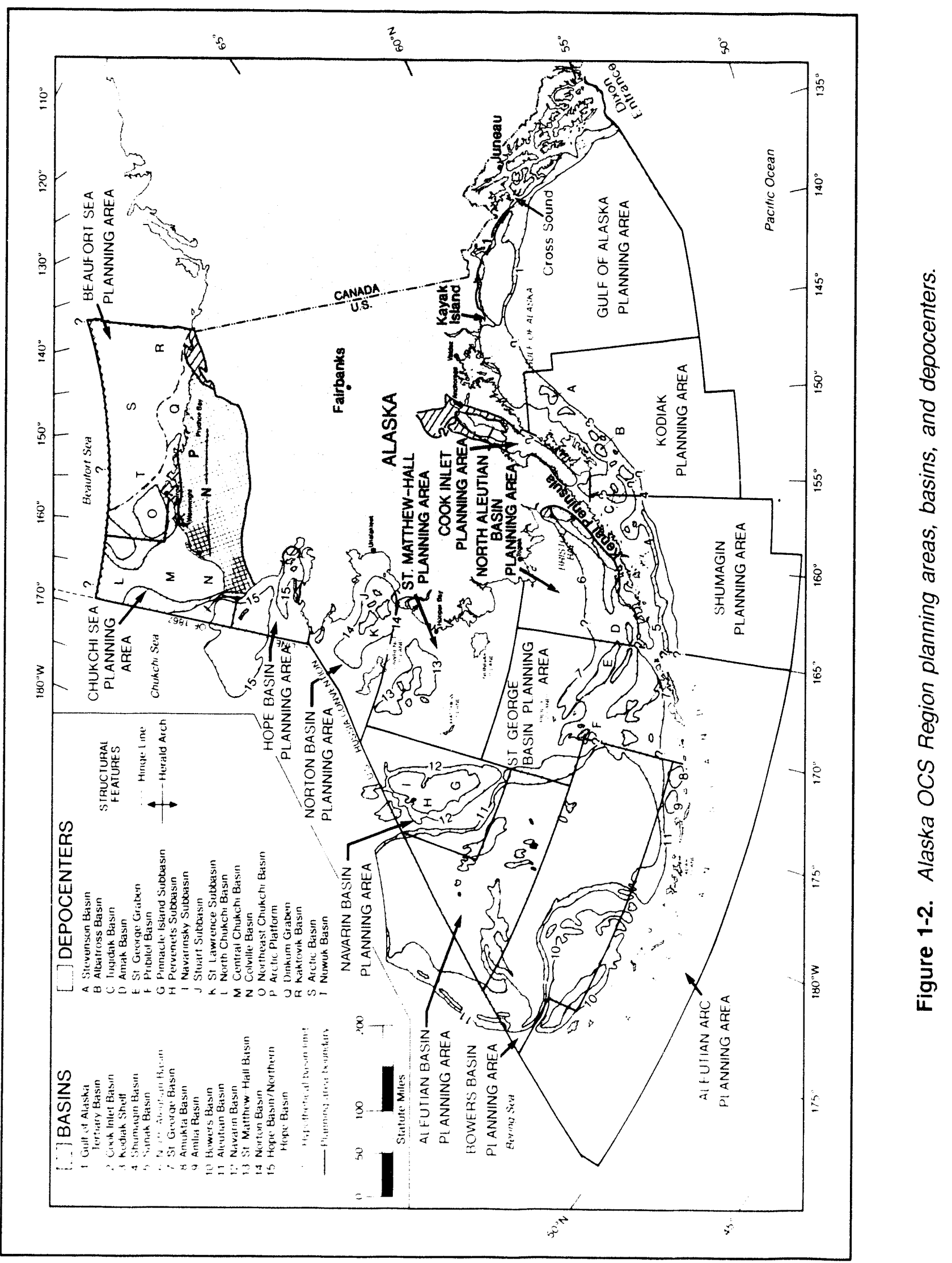


Table 1-2. COST wells drilled on the Alaska OCS

\begin{tabular}{|c|c|c|c|c|c|c|}
\hline $\begin{array}{l}\text { Planning area/ } \\
\text { well number }\end{array}$ & $\begin{array}{l}\text { Lease/block } \\
\text { number }\end{array}$ & Operator & $\begin{array}{l}\text { Spud } \\
\text { date }\end{array}$ & $\begin{array}{c}\text { Total } \\
\text { depth }(f t)\end{array}$ & $\begin{array}{l}\text { Date total } \\
\text { depth reached }\end{array}$ & $\begin{array}{l}\text { Report* } \\
\text { number }\end{array}$ \\
\hline \multicolumn{7}{|l|}{$\begin{array}{l}\text { Arctlc Subreglon: } \\
\text { None }\end{array}$} \\
\hline $\begin{array}{l}\text { Bering Sea Subreg } \\
\text { Norton Sound } \\
\text { COST } 1\end{array}$ & $\begin{array}{l}\text { OCS } 80-7 \\
\text { Block } 197\end{array}$ & ARCO & $06 / 14 / 80$ & 14,583 & $09 / 16 / 80$ & OFR $83-124$ \\
\hline $\begin{array}{l}\text { Norton Sound } \\
\text { COST } 2\end{array}$ & $\begin{array}{l}\text { OCS } 82-16 \\
\text { Block } 273\end{array}$ & ARCO & $06 / 07 / 82$ & 14,889 & $08 / 27 / 82$ & OFR 83-557 \\
\hline $\begin{array}{l}\text { Navarin Basin } \\
\text { COST } 1\end{array}$ & $\begin{array}{l}\text { OCS } 82-17 \\
\text { Block } 801\end{array}$ & ARCO & $05 / 26 / 83$ & 16,400 & $10 / 03 / 83$ & MMS 84-0031 \\
\hline $\begin{array}{l}\text { St. George Basin } \\
\text { COST } 1\end{array}$ & $\begin{array}{l}\text { OCS } 76-11 \\
\text { Block } 459\end{array}$ & ARCO & $07 / 02 / 76$ & 13,771 & $09 / 22 / 76$ & MMS 84-0016 \\
\hline $\begin{array}{l}\text { St. George Basin } \\
\text { COST } 2\end{array}$ & $\begin{array}{l}\text { OCS } 82-19 \\
\text { Block } 390\end{array}$ & ARCO & $05 / 19 / 82$ & 14,626 & $08 / 22 / 82$ & MMS 84-0018 \\
\hline $\begin{array}{l}\text { N. Aleutian Basin } \\
\text { Cost } 1\end{array}$ & $\begin{array}{l}\text { ()CS } 82-18 \\
\text { Elock } 666\end{array}$ & ARCO & $09 / 08 / 82$ & 17,155 & $01 / 14 / 83$ & $\star \star$ \\
\hline $\begin{array}{l}\text { Gulf of Alaska } \\
\text { Subreglon: } \\
\text { Cook Inlet } \\
\text { COST } 1\end{array}$ & $\begin{array}{l}\text { OCS } 77 \% 5 \\
\text { Block } 489\end{array}$ & ARCO & $06 / 10 / 77$ & 12,387 & $09 / 24 / 77$ & OFR $78-145$ \\
\hline $\begin{array}{l}\text { Kodiak Shelf } \\
\text { KSST } 1\end{array}$ & $\begin{array}{l}\text { OCS } 76-35 \\
\text { Block } 573\end{array}$ & $\mathrm{ESCl}$ & $07 / 13 / 76$ & 4,225 & $08 / 01 / 76$ & $\star \star$ \\
\hline $\begin{array}{l}\text { Kodiak Shelf } \\
\text { KSST } 2\end{array}$ & $\begin{array}{l}\text { OCS } 76-35 \\
\text { Block } 984\end{array}$ & $\mathrm{ESCl}$ & $08 / 04 / 76$ & 4.337 & $08 / 23 / 76$ & $\star \star$ \\
\hline $\begin{array}{l}\text { Kodiak Shelf } \\
\text { KSST } 4\end{array}$ & $\begin{array}{l}\text { OCS } 76-35 \\
\text { Block } 781\end{array}$ & $\mathrm{ESCl}$ & $08 / 28 / 76$ & 1,391 & $09 / 19 / 76$ & $\star \star \star$ \\
\hline $\begin{array}{l}\text { Kodiak Shelf } \\
\text { KSSD } 1\end{array}$ & $\begin{array}{l}\text { OCS } 77-1 \\
\text { Block } 999\end{array}$ & Sun & $05 / 25 / 77$ & 8,514 & $07 / 17 / 77$ & $\star \star$ \\
\hline $\begin{array}{l}\text { Kodiak Shelf } \\
\text { KSSD } 2\end{array}$ & $\begin{array}{l}\text { OCS } 77-1 \\
\text { Block } 463\end{array}$ & Sun & $07 / 22 / 77$ & 10,452 & $09 / 08 / 77$ & $\star \star$ \\
\hline $\begin{array}{l}\text { Kodiak Shelf } \\
\text { KSSD } 3\end{array}$ & $\begin{array}{l}\text { OCS } 77-1 \\
\text { Block } 14\end{array}$ & Sun & $09 / 13 / 77$ & 9,355 & $10 / 25 / 77$ & $\star \star$ \\
\hline $\begin{array}{l}\text { Northern Gulf of } \\
\text { Alaska-COST } 1\end{array}$ & $\begin{array}{l}\text { OCS } 76-60 \\
\text { Block } 196\end{array}$ & $A R C O$ & $07 / 22 / 75$ & 5.100 & $10 / 09 / 75$ & OFR $76-635$ \\
\hline 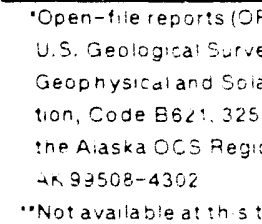 & $\begin{array}{l}\text { Vailable at cost from } \\
\text { ral Center-Box } 254 \\
\text { stral Data Center, } \\
\text { ay, Boulder, Co } 803 \\
\text { ary, Minerais Manas }\end{array}$ & $\begin{array}{l}\text { nener. Co } 30 \\
\text { na. Oceanic \& } \\
\text { MMS report } \\
\text { nt Service. } 9\end{array}$ & $\begin{array}{l}\text { ffom the Nat: } \\
\text { opheric Admin } \\
\text { atlable at cos: } \\
\text { 5th Ave. Anct }\end{array}$ & & & \\
\hline
\end{tabular}


Twelve exploratory wells, including or: a sidetrack, were drilled in the planning area between 1976 and 1993. All well.: vere dry. The only field to produce along the Gulf of Alaska - the onshore Katalla Field north of Kayak Island produced oil $\left(40^{\circ}-44^{\circ}\right.$ API gravity) from fractured rock along a fault zone in the Katalla Formation, a local equivalent of the Poul Creek Formation.

Offshore, the Poul Creck Formation is a silty shale to shaly siltstone that may coniain potential source rocks for petroicum. The formation does not contain any prtential reservoir quality rocks except in the sandier, uppernost part of the formation. Generally, the offshore wells that encountered the Poul Creek Formation found thermally immature source rocks. However. the Atlantic Richfield Company (ARCO) $Y-1)(0) 7$ well has values that range from moderately immature to moderately mature, based on the light reflectance of fossil organic fragments in oil immersion (vitrinite reflectance). The total organic carbon (TOC) ranges from slighily greater than 1 percent in the $Y-(0211$ well to less than 0.5 percent in the remaining wells tested. The Kulthieth Formation also may contain potential reservoir rocks and may possibly be a source for petroleum, but this formation was encountered only in the $\mathrm{Y}-(1211$ well. In that well, minor oil stained sands and moderate thermal maturity levels were ieached at 13,70$)$ feet $(4,180 \mathrm{~m})$, but were judged to be uneconomic. The source rocks at this depth are mature and contain slightly greater than 1 percent TOC. These source rocks are more gas prone than oil prone. All of the offshore exploratory wells have drilled into the Yakataga Formation, which is a very poor source rock, containing low TOC values, with low maturity, and is generally only a fair reservoir rock.

Potential traps have been identified in the Yakataga and Kulthieth formations. These traps include (1) large, asymmetric, elengate and doubly plunging, faulted anticlines; $(2)$ traps against major faults; (3) simple anticlines: and (4) stratigraphic pinch-outs.
In the part of the planning area encompassing the continental slope and areas seaward, organic-rich layers within turbidite sequences were encountered at Deep Sea Drilling Project (DSDP) sites 178 and 180. These layers contain between 1 and 3 percent organic carbon. However, because of the young age of these deposits, the shallow burial depths, and low heat flow, these potential source rocks are not mature. Because of lack of maturity and a general lack of reservoir potential, this area is not presently under consideration for resource development.

\section{Cook Inlet Planning Area}

The Cook Inlet Planning Area is part of the Alaska Peninsula-Cook Inlet Province and includes both the Lower Cook Inlet and Shelikof Strait. Rocks of the area are part of a belt of Mesozoic and Cenozoic sedimentary rocks that underlic Upper Coo:. Inlet. Along this belt, marine Mesozoic rocks may locally be more than $36,000$ feet $(12,000) \mathrm{m})$ thick, and continental Cenozoic rocks are as much as 25,000 feet $(7,600 \mathrm{~m})$ thick. Sedimentary rocks are mainly clastic and are grouped into four sequences on the basis of geologic age: Jurassic, Early Cretaceous, Late Cretaceous, and Tertiary. While most subsurface features parallel the general northeast-southwest trend of the basin(s), a notable exception is the east-west-trending Augustine-Seldovia Arch ir Lower Cook Inlet at approximately $59^{\circ} \mathrm{N}$. latitude. This arch separates the southern part of the Cook Inlet Basin from the basin that underlies Shelikof Strait.

All occurrences of commercially important petroleum to date in the Cook Inlet Basin are in the northern portion under State waters and onshore. The petroleum is contained in sandstone and conglomerate reservoirs of middle to eariy Tertiary age in north-northeast-trending compressional folds. The occurrence of oil is restricted to the lower Tyonek, Hemlock, and West Foreland fomations of Excene to Oligocene age. The source of the sil is difficult to determine, but is generally attributed to the underlying Middle Jurassic siltstones, and all of the 
major oil occurrences involve Tertiary reservoirs overlying Jurassic rocks. Likely avenues of migration are the large unconformity that separates the Tertiary and Jurassic rocks, and the large-scale faulting associated with the compressional folds.

Large dry-gas deposits are found in sandstone reservoirs within the upper Tyonek, Beluga, and Sterling formations of late Miocene to) Pliocene age. The gas is almost pure methane of biogenic origin. Large volumes of subbituminous to lignitic coal occur throughout the Miocene-Pliocene section.

Thirteen exploratory wells have been drilled between 1978 and 1985 in Lower Cook Inlet and Shelikof Strait. However, three of these wells were abandoned at shallow depths because of hole problems and were redrilled at approximately the same locations. One COST well was drilled in 1977 in Lower Cook Inlet. The Lower Cook Inlet-Shelikot OCS areas are known to contain stratigraphic sequences similar to that of the Upper Cook Inlet, as a result of extensive marine seismic surveys on onshore mapping of exposed rocks. The differences are, however, important. The Tertiary section thins rapidly to the south. and exists primarily as a thin veneer of lower Tertiary conglomerate orer the Shelikof Strait area. Structural deformation of the Tertiary section has been much more gentle than in Upper Cook Inlet, and a thick sequence of marine Cretaceous rocks separates the Tertiary section from the Jurassic. As a result, Tertiary reservoirs were found to be relatively shallow compared with the Upper Cook Inlet producing area. and whereas major petroleum accumulations involved Tertiary reservoir rocks overlying Jurassic source rocks, that configuration is not present nor is the possible migration route along the unconformity. The Jurassic rocks were partially penetrated by nearly all the wells to as much as $12,0(0)$ feet $(3.6 .50 \mathrm{~m})$. This section is very sandy, but it is diagenetically altered and has uniformly low porosity and permeability because of cementation. These rocks have poor reservoir potential.
The Early Cretaceous rocks range in thickness from 0 to 2,500 feet $(760 \mathrm{~m})$. Although this interval has numerous sands, the sands have low porosities and permeabilities. The reservoir potential for the Early Cretaceous is considered to be poor.

Rocks in the Late Cretaceous are both marine and nonmarine. The marine section has from 1,000 to 5,000 feet $(300$ to $1,520 \mathrm{~m})$ of siltstone. These rocks have very few sands and the sands have low porosity and poor reservoir potential. In contrast, the nonmarine rocks are sandier and have marginal porosities; two wells to the north had noncommercial quantitics of oil. However, the nonmarine section has only been found in the west central part of Cook Inlet.

The Tertiary rocks are predominantly Eocene to Miocene in age. These rocks are from 50() to 5,000 feet $(150$ to $1,520 \mathrm{~m})$ thick, and their lithology ranges from tuffaceous siltstore to massive conglomerate. Even though this section has low porosity and very poor reservoir potential, in general, some Oligocene to Miocene rocks do have good reservoir potential. The organic carbon content may be more abundant in the upper part of the total section in the area. However, the section in general does not contain good prospective source rocks. The Continental Offshore Stratigraphic Test (COST) well data showed that the thermo-chemical transformation of the organic matter is marginally mature, but the organic matter is prominantly the type that has poor oil-generating capacity.

\section{Kodiak Planning Area}

The Kodiak Planning Area is located in the northwestern area of the Pacific-Margin Tertiary Province and extends from the Kenai Peninsula to roughly the southern end of Shelikof Strait at $156^{\circ} \mathrm{W}$. longitude. Six decp stratigraphic test wells have been drilled on the Kodiak shelf. Three wells were drilled as part of the Kodiak Shelf Stratigraphic Test (KSST) Program in 1976, and three were drilled in the 
Kodiak Shelf Stratigraphic Drilling (KSSD) Program in 1977. In addition, the Tenneco Middleton Island State No. 1 well, drilled in the adjacent Gulf of Alaska Planning Area in 1969, also provides relevant geologic information. The tectonic setting and evolution of the Kodiak shelf have been strongly controlled by (1) the subduction of the Pacific and Kula plates, which has been occurring beneath the North American plate since early Mesozoic time, and (2) the accompanying accretion of arc-derived turbidites and allochthonous-tectono-stratigraphic terranes.

Structurally, the Kodiak shelf encompasses several small basins. The landward flank of the basins is a wide zone of faults that separates the subsiding forearc basins from the uplifted block of Kodiak Island itself. The seaward flank is generally an asymmetric arch at the edge of the continental shelf.

The sheli is underlain by two major tectonostratigraphic units represented by the acoustic basement and the overlying stratified sequence. Acoustic basement beneath the shelf is composed of a highly deformed assemblage of flysch and mafic volcanic rocks that are Cretaceous in age. These basement rocks are in structural contact with up to 10,000 fect of highly deformed slope and gently deformed shelf deposits that are Palcocene in age. These Paleocene deposits are unconformably overlain by gently deformed shelf deposits ranging in age from Miocene to Holocene.

On the basis of onshore geology, source rock potential for most rocks underlying the Kodiak shelf is poor. Most strata contain less than 0.5 pereen TOC, rendering them marginal potential sources at best. Three groups of rocks sampled along the Kodiak margin contain more than $(0.5$ percent TOC (0.58-(0.6):

- Sitkinak Formation (Oligocene). a fluvial to shallow-marine deposit;

- Tugidak Formation (Pliocene), a shelf deposit; and
- early Pleistocene (?) to Holocene deposits under the continental slope sampled at DSDP sites 181 and 182 .

Data from the Middleton Island well suggest that isolated source beds may be present throughout the Tertiary section. These data indicate that structured kerogen predominates. Hence, these rocks would tend to generate gas rather than oil. Significant exceptions to this pattern are Eocene beds that contain primarily amorphous kerogen that could generate oil rather than gas. Thermal maturity for rocks underlying Kodiak shelf is low, and oil, if present, is in the early generation stage; thermogenic gas generation has not yet begun.

Folds and faults that deform the shelf sequence trend predominantly northeast. These structures are superimposed on larger scale transverse uplifts. Recognized hydrocarbon traps underlying the Kodiak shelf are simple structures limited to Neogene strata. Trap types include simple folds, fault closures, and unconformity truncations. No regional seals are known to be present, but interbedded shales capable of acting as local seals are likely to be present.

Because of their lithology and degree of atteration, reservoir rocks are unlikely to be present in Paleogene strata. Samples from turbidites of the Ghost Rocks Formation (Palcocene) and the Sitkalidak Formation (Eocene) indicate porosities of 1 to 3 percent and permeabilities of less than 0.1 millidarcy (mD). However, some reservoir rocks with reservoir-quality porosity and permeability are inferred to be present in Neogene strata. Direct measurements of the porosity and permeability of Miocene and younger sandstones exposed onshore are not available; however, thin Pliocene sands of the Yakataga Formation in the Middleton Island well range up to 18 percent in porosity. Lithologic descriptions of outcrops on Kodiak and surrounding islands reveal that sediment tends to increase in compositional maturity and in porosity and permeability with decreasing age throughout the sampled part of the Neogene. 
Acoustic basement under the Middleton Island segment of the shelf consists of graywackes, argillites, slates, and volcanics of the Orca Group of the allocthonous Prince William terrane. Sandstones, siltstones, and calcareous siltstones equivalent to the Eocene Sitkalidak Formation comprise a target interval; this is unconformably overlain by the siltstones and mudstones of a late Eocene (?) to Miocene unit equivalent to the Sitkinak and Poul Creck formations. This interval, in turn, is unconformably overlain by the mudstones, siltstones, and sandstones of the late Miocene to Pleistocene Yakataga Formation.

\section{Shumagin Planning Area}

The tectonic setting and evolution of the Shumagin shelf, like the Kodiak shelf, have been controlled by the interaction between the Pacific and Kula plates and the North American plate. Since Late Cretaceous time, the Pacific and Kula plates have migrated northward relative to mainland Alaska and the North American continent, and at the Aleutian Trench, they are subducted beneath the Alaskan continental margin.

A shelf-type Mesozoic sequence of volcaniclastic sandstones and siltstones are exposed on the Alaskan Peninsula. To the southeast, the Shumagin Formation, a decp-water turbidite sequence of Late Cretaceous age. crops out on Sanak and the outer Shumagin Islands. The islands are an uplifted portion of the Shumagin shelf, which exposes a highly folded and faulted subduction complex decp-water flysch sequence of interbedded sandstone and mudstone that have been intruded by Paleocene granitic plutons.

The Shumagin margin consists of a number of basins separated by transverse ridges, including the western flank of Tugidak Basin. Shumagin Basin, the cast and west Sanak basins, the east Sanak Slope Basin, and the Unimak Basin. Geophysical interpretations beneath the Shumagin sheif may indicate two sedimentary sequences composed of a predominantly Neogene seismic sequence, and a Paleogene scismic sequence overlying a Cretaceous-Paleogene basement.

The structural trends of the Shumagin Formation on the outer Shumagin Islands generally strike northeast parallel to the Aleutian Trench, whereas their structural trend on the Sanak Islands strike northwest toward Unimak Island, parallel to the ancient margin of the Beringian shelf.

Offshore geophysical data indicate the presence of numerous structural and stratigraphic features that may be capable of entrapping hydrocarbons. However, verification of closure, in most cases, has been tentative because of the low density of available scismic-reflection data.

On the adjacent Kodiak shelf, six stratigraphic test wells were completed in 1976 and 1977. Geophysical interpretations extrapolated from the Kodiak shelf indicate that the major tectono-stratigraphic units underlying the Kodiak shelf may underlic the Shumagin shelf basins. Exposures of the Prince William Terrane on Kodiak Island correlate the clastics of the Miocene Narrow Cape and Oligocene Sitkinak formations with the Neogene seismic sequence and the highly folded Excene deep-water volcano-genic siltstones and sandstones of the Sitkalidak Formation with the Paleogene seismic sequence. The Kodiak stratigraphic test wells were drilled through a Neogene sequence and a Paleogene sequence of strata. These strata are coeval with Tertiary strata exposed on Kodiak Island.

Exposures on the Kodiak lslands indicate that Eocene strata of the Sitkalidak Formation (coeval with the Paleogene seismic sequence) have the greatest potential for the generation of hydrocarbons. These strata contain terrestrially derived. gas-prone herbaceous and woody type kerogen, which is lean in total organic carbon content. The Eocene section is thermally immature at onshore localities. It presumably 
has reached thermal maturity and generated some hydrocarbons within offshore basins.

The best reservoir rocks on Kodiak Island occur within the basal transgressive quartz-rich sands of the Narrow Cape Formation, coeval with the Neogene seismic sequence. Paleogene sandstones on Kodiak Island, coeval with the Paleogene seismic sequence, are lithic and volcanic-rich and accordingly have poor reservoir characteristics.

Anticlines, faulted anticlines, stacked thrusts, normal and reverse faults, along with stratigraphic pinch-outs and truncations at unconfonnities, are possible trapping mechanisms. To date, there has been no geologic data on the Shumagin shelf to verify the presence of either a potential source bed sequence or a porous reservoir sequence. However, geologic analysis of potential hydrocarbon sources and potential reservoirs from the a(ijacent Kodiak shelf suggest a low to moderate probability, at best, for the occurrence of hydrocarbons beneath the Shumagin shelf.

\section{North Aleutian Basin Planning Area}

The North Aleutian Basin Planning Area actually encompasses two sedimentary basins, the North Aleutian and Amak basins. The North Aleutian Basin is a large, sediment-filled, west-trending structural depression that underlics portions of both the Alaskid Peninsula and the Bering Sea. Approximately four-fifths of the basin's total area is located offshore in water depths of less than 200 feet $(60 \mathrm{~m})$. Asymmetrical in cross section, the basin is bounded on the north by gently dipping basement rock and on the south by a more steeply inclined basement ridge. Mesozoic rocks that form this ridge crop out in the Black Hills on the Alastia Peninsula. The Amak Basin, located to the south of the basement ridge, is smaller than the North Aleutian Basin in areal extent and contains a thinner sedimentary section.

Sedimentary fill in the North Alcutian Basin consists of up to $2(1,()(0)$ fect $(6,100) \mathrm{m})$ of $\mathrm{Ce}$ - nozoic sediment, which is thickest in the southeastern part of the basin. Paleogene formations exposed onshore on the adjacent Alaska Peninsula include the Tolstoi, overlain by the Meshik and its lateral equivalent, the Stepovak. The Tolstoi and Stepovak formations are composed of mostly volcanogenic sediments: conglomerate, sandstone, and breccia with some interbedded siltstone and coal. The Meshik Formation is primarily composed of volcanic rock: flows, tuffe, and agglomerates. The Stepovak Formation, in addition to volcano-genic sandstone and conglomerate, also contains thick beds of black siltstone turbidites. All three formations are dense and highly indurated. The Bear Lake and the Milky River formations compose the Neogene sequence. The Bear Lake Formation is composed of interbedded relatively quartzose porous sandstone, conglomerate, siltstone and, locally, coal. The overlying Milky River Formation is composed of volcanic sandstones and breccias, conglomerate, and mudstone. The Neogene formations and the overlying Pleistocene volcanic flows and breccias were deposited in shallow-marine to nonmarine environments. Seismic data indicate that all Cenozoic formations may continue in the offshore section, but dip to greater depths.

One COST well was drilled offshore in 1983, and 19 exploratory wells have been drilled on the Alaska Peninsula. Although a number of oil and gas shows were reported in the southern Peninsula area, none suggest a discovery of commercial size. Data from the onshore wells suggest that the most prospective area for hydrocarbons in the planning area lies offshore between Port Moller and the area north of Cold Bay. Geophysical data indicate that this area contains both the thickest Tertiary section and also the most promising anticlinal structures. In the southwestern comer of the basin and to the northeast, north of Port Heiden, the structures are less promising. There may be stratigraphic or fault traps along the southern flank of the offshore extension of the Black Hills uplift. North of $57^{\circ}$ latitude, a thin, ilat-lying Tertiary section overlying basement rocks provides little incentive for intensive exploration. 
The stratigraphic section of the planning area can be divided into three major plays: an Upper Tertiary play, a Lower Tertiary play, and a basement play. The Upper Tertiary play is composed of about 8,000 feet $(2,400 \mathrm{~m})$ of clastics, consisting predominantly of the Bear Lake and Milky River formations. The Lower Tertiary play is made up of up to 3,000 feet $(900 \mathrm{~m})$ of clastics consisting predominantly of the Stepovak and Meshik formations. In the case of the Bear Lake Formation, sediments appear to be derived from a predominantly igneous source terrane and deposited in transitional and neritic environments. The Milky River and Meshik formations, and to a lesser degree, the Stepovak Formation, derive from a volcanic source terrane. Source rocks for both plays have not yet matured to the stage of significant liquid t.ydrocarbon generation, and oil accumulation may depend on migration from outside the plays. The basement play is composed of Mesozoic-age clastic sediments of unknown thickness that are derived from an igneous source terrane. Sandstone reservoir quality in these rocks probably has degraded because of diagenetic alteration of unstable framework grains. At the depth of burial of this play, organic material is must likely thermally mature to over mature.

Data from the Gulf Sandy River and Pan American David River wells indicate that the middle to late Miocene sandstones of the Bear Lake Formation may have the greatest reservoir potential. Above 6,300 feet $(1,920 \mathrm{~m})$, these sandstones have porosities as high as 36.5 percent and permeabilities as high as 1,286 mD. Below this depth the corresponding high values are 29 percent ard $43 \mathrm{mD}$. A show of oil and gas in the Gulf Sandy River well and gas in the Pan American David River well Bear Lake Formation sandstones have yielded, and may possibly yield hydrocarbons offshore. Shows of oil and gas were also reported from sandstone beds in the Stepovak and Tolstoi formations in the Pan American Hoodoo Lake well.

The best Tertiary source rocks appear to be the black marine siltstone and shale beds in the
Oligocene Stepovak Formation. Analysis of several wells onshore reveals that although thermally immature, the Paleogene strata are rich in organic matter. Offshore, however, these rocks may be more mature due to the greater depth of burial. Other potential source rocks include the basal units of the Bear Lake Formation (although there may not have been enough burial of most of this formation to generate petroleum liquids) and Jurassic and Cretaceous age marine shales. The Amoco Cathedral River well to the west of Port Moller was spudded into Jurassic rocks, yielding samples with TOC values of less than 1 percent. Sandstone chips did not indicate any visible porosity. The northern group of Alaska Peninsula wells (above $57^{\circ} \mathrm{N}$. latitude) bottomed in volcanic and granitic rocks and reported no significant oil and gas shows.

\section{St. George Basin Planning Area}

The St. George Basin Planning Area contains two main depocenters for sediments that occur on the continental shelf: the St. George Basin and the Pribilof Basin. They are separated by a structural high, the Pribilof Ridge. Four plays have been recognized on the shelf in the planning area: (1) the St. George Basin itself, (2) the platform south of St. George Basin, (3) the platform north of St. George Basin, and (4) the Pribilof Basin. The St. George Basin is a northwest-trending graben that contains as much as 40,000 feet $(12,200$ $\mathrm{m})$ of Cenozoic and Mesozoic sediments. The Pribilof Basin is a half graben that contains as much as 20,000 feet $(6,100 \mathrm{~m})$ of $\mathrm{Ce}$ nozcic sediments. The shelf area south of the graben to the continental slope contains $3,000-10,000$ feet $(900-3,000 \mathrm{~m}$ ) of Cenozoic sediment over mostly sedimentary basement rocks. The area up to within 25 miles $(40 \mathrm{~km})$ north of the graben contains 3,000-7,000) feet $(90)-2,100 \mathrm{~m}$ ) of Cenozoic sediment. In this area, basement is probably composed of Mesozoic and lower Tertiary sedimentary rocks. The remainder of the shelf area to the norts of the graben has a very thin Tertiary 
section over an igneous basement and is not considered prospective.

By 1976, exploration began in the area with the drilling of a COST well. A second COST well was drilled in $\mathbf{1 9 8 2}$. Nine exploratory wells were drilled in St. George Basin during 1984 ard 1985, with total depths ranging between $8,0(0)$ and 13,90$)(0$ feet $(2,400$ and 4,237 ii1). No significant shows of hydrocarbons were encountered.

The COST No. I well was drilled about 25 miles $(40 \mathrm{~km})$ south of the graben and encountered about $10.0(0)$ feet $(3,000) \mathrm{m})$ of Tertiary sediments overlying igneous basement. The COST No. 2 well was drilled along the southeastern margin of the graben and encountered over 12.000 feet $(3.650 \mathrm{~m})$ of Tertiary sediments overlying Mesozoic sedimentary rocks.

Mesozoic rocks encountered along the southeastem margin of the graben range in age from Late Jurassic to Early Cretaceous and are mostly fine-grained sandstones with minor shale and coal stringers. Upper Jurassic marine conglomerates at the base of the section are believed to be the equivalent of the Naknek Formation on the Alaska Peninsula. The overlying Lower Cretaceous fine-grained sandstone, shale, and coal were derived from a volcanic source terrane and deposited in a fluvial to deltaic environment. These rocks may be the equivalent of the Staniukovich Formation, which overlies the Naknek on the Alaska Peninsula. Late Cretaceous sandstones and siltstones recovered from dredge hauls in Pribilof Canyon may be correlated with the onshore Hoodos Formation.

Cenozoic strata range in age from middle Eocene to Holocene in the COST No. I well and carly Eocene to Holocene in the COST No. 2 well. Dominant lithologies include finegrained sandstones, siltstones, mudstones, and minor conglomerate. Volcanic rock fragments are eommon throughout. The sediments were deposited in mostly a marine shelf environment. A middle Eocene conglomerate is at the base of the Tertiary section in the COST No. 1 well. During Oligocene time, conditions became more marine, possibly due to rapid shelf subsidence, with the deposition of outer neritic to upper bathyal sandstones, siltstones, and mudstones. An unconformity is apparent in the upper Oligocene section near the shelf edge. Miocene samples of mudstones, siltstones, and sandstones indicate an outer neritic to upper bathyal environment. Pliocene and Pleistocene strata consist of sandstone, siltstone, and mudstone deposited in a neritic environment.

Potential traps in the St. George graben include faulted anticlines, fault traps, drape structures, and stratigraphic traps. Outside of the graben, potential traps include anticlinal structures, drape structures, fault traps, and stratigraphic traps. In the Pribilof Basin, potential traps include anticlines, drape, fault traps, and subunconformity truncation associated with fault-bounded anticlines.

The best potential reservoir rocks are believed to occur in the Oligocene section. At COST No. I well, Oligocene sands attained thicknesses greater than 150 feet $(46 \mathrm{~m})$. Porosities were as high as 25 percent and parmeabilities were as high as $37 \mathrm{mD}$. The volcanic rock fragments tend to reduce porosity and permeability because of diagenetic alteration to zeolites and clay minerals. In the COST No. 2 well, the Oligocene sandstones are less porous and permeable.

Exxon drilled two wells on a horst block in the center of the St. George graben. The $Y$ 0530 No. 1 well cored a basal Tertiary conglomerate, which had an average porosity of only 7.5 percent and a permeability of less than $1 \mathrm{mD}$. There were no permeable sands in the Tertiary section. The Y-(0527 No. I well cored a sandy Miocene section with porosities from 18 to 22 percent, but with permeabilities of less than $3 \mathrm{mD}$. A sandy section in the lower Oligocene averages 24 percent porosity. In general, the porosity decreases with depth due to compaction and the growth of secondary mincrals. 
The source rock potential, as indicated by the COST wells, appears to be low. The sediments were low in TOC and were deposited under oxidizing conditions. Only gas-prone kerogen types were present in samples from the wells. Vitrinite reflectance data indicated the Tertiary sediments to be immature for oil gencration. The TOC for the COST No. 1 well ranges from less than 0.5 percent to 0.7 percent. In the COST No. 2 well, TOC values are roughly from 0.5 pereent to 1.0 pereent. The "oil window" occurs at approximately $12,0(0)$ feet $(3,60)(0 \mathrm{~m})$. No geochemical data are available from the Exxon wells.

The deeper portions of the St. George graben may have better source rock potential than the COST well sites because the basal graben sediments were deposited in an enclosed basin when the area south, where the COST wells were drilled, was emergent. Restricted circulation in the early stage of graben development may have been conducive to organic preservation. Thermal maturity in the graben may also be more favorable than for the COST well locations because the basal graben sediments are buried more decply than the lowermost Tertiary sediments at the COST well sites. Therefore, the sediments may have been exposed to high enough temperatures for a sufficiently long time to generate oil. The Pribilof Basin, which remains unexplored, may also have adequate source rocks for the same reasons. How ever. the four ary holes alrealy drilled in the graben and the five dry holes south of the graben indicate a low resource potential in this area.

\section{Aleutian Basin, Bowers Basin, and Aleutian Arc Planning Areas}

The Aleutian Basin, Bowers Basin, and Aleutian A:c planning areas encompass various basins that span more than one of these planning areas. In general, these basins, which provide the framework for the following discussion, are part of the western Bering Sea, which has water depths greater than $10,(0)(0)$ feet $(3,0)(0)$ min.
The Alcutian Basin is generally thought to be floored by Early Cretaceous oceanic crust because of the identification of norti-striking magnetic anomalies M1 through M13. The crust and lithosphere are thought to be a remnant of the Kula plate, which was being subducted beneath the Beringian margin prior to the earliest Tertiary, when subduction shifted southward to the site of the present-day Aleutian Ridge.

Sediments, including highly indurated siliceous rocks, mudstones, and possibly carbonates, overlying the crust of the Alcutian Basin are approximately $10,0(0)-13,0(0)$ fect $(3,0)(0)$ $4,(0)(0 \mathrm{~m})$ thick. These sediments are acoustically well stratified as would be expected for turbidites or other sediments with rapid vertical variations in acoustic impedance. The surficial sediments are flat lying and show no evidence of tectonic disruption. Deeper sediments onlap basement highs and, in places, appear to be faulted. A portion of the basin has sediment thicknesses approaching 26,000$)$ feet $(7,900 \mathrm{~m})$, which appear to be folded.

The Bowers Basin is thought to have formed because of back-are spreading associated with the subduction of the Kula plate beneath the Bowers Ridge. Subduction of the Kula plate is thought to have ceased prior to the initiation of subduction bencath the Alcutian Ridge, which forms the southern boundary of the basin. Sediments in the abyssal portion of the basin have not been sampled to depths greater than a few meters. Acoustically, they appear to be very similar to those of the Alcutian Basin, that is, the shallow sediments are flat lying and well stratified; the decper sediments are less stratified. In general, the basin appears to be floored by oceanic crust and covered by $6,5()(1)$ $10,(0)$ feet $(1,98()-3,()()) \mathrm{m})$ of hemipelagic silt and clays.

The Aleutian Ridge is a volcanic island chain formed as a result of the subduction of oceanic lithosphere bencath the Bering Sea. The oldest known volcanic rocks on the ridge are roughly 50 million years old and are from 
Adak Island. Sparse data are available from the Bowers Ridge; however, in the absence of contradictory data, the Bowers Ridge is expected to have had a similar tectonic evolution and, consequently, similar structural features and petroleum potential.

Sedimentary basins associated with the Alcutian Ridge include summit basins, such as Amlia Basin and Amukta Basin, which lie on the north flank of the ridge. These basins are grabens or half-grabens and are a result of $\mathrm{Ce}$ nozoic :rustal extension ale $1 \mathrm{~g}$ the crest of the ridge. Toc basins contain approximately 6,500 $10,000)$ feet $(1,980-3,000 \mathrm{~m})$ of folded and faulted sediments, which may be as old as midNe Miocene. The sediments in these basins are thought to be volcaniclastic sandstones and siltstones.

On the south flank of the Alcutian Ridge, sediments have been trapped between an eaststriking basement ridge and a summit platform forming Atka Basin. This forearc basin contains sediments as old as Plio-Pleistocene.

Exploration in these basins has been limited (1) the collection and analysis of multichannel seismic reflection data and the drilling of some Deep Sea Drilling Project (DSDP) holes (specifically, nos. 186, 187, 188, and 190) in 1971.

Thick sediment deposits with possible structural traps have been identified in the Aleutian Basin and in summit and forearc basins along the Alcutian Arc. Thinner deposits lie in the Alcutian trench. The available data suggest that the deeper sediments in many of these locations are thermally mature. The quantity of available organic material in the sediments, although low, may be sufficient to generate enough hydrocarbons to permit migration into the traps. Migration and accumulation may be impeded by the low permeabilities commonly associated with volcaniclastic sediments. particularly for sediments on the Aleutian and Bowers ridges and at the base of the Bowers Ridge and beneath the Bering shelf rise and slope. However, data are insufficient to pre- clude the possibility that permeable sand units may exist, particularly within the summit and forcarc basins of the Alcutian Arc.

\section{St. Maithew-Hall Basin Planning Area}

St. Matthew-Hall Basin formed as a crustal sag in the mid-continental shelf of the Bering Sea just south of St. Lawrence Island. The sag probably formed as a consequence of regional downwarping associated with Late Cretaceous or early Tertiary strike-slip motion of the Kaltag Fault. A major carly Tertiary unconformity cuts the Mesozoic basement complex, which is believed to be part of the OkhotskChukotsk volcanic belt. In western Alaska, the volcanic belt is correlative with a broad zone of Cretaceous to early Tertiary volcanic and sedimentary rocks, which make up the YukonKoyukuk Province.

The basin is filled with less than 6,00(0) feet $(1,800) \mathrm{m})$ of layered Tertiary fill. The fill is probably Oligocene- and Neogene-age neritic marine and transitional fine-grained sediments, which are overlain by a relatively thin veneer of coarser grained Quaternary sediments.

No exploratory or COST wells have been drilled in the St. Matthew-Hall Basin, but wells have been drilled in the structurally similar Norton Basin and in adjacent areas of western Alaska.

There are a few basement-controlled faulted anticlinal structures that occur within $3,0(0)$ feet $(90() \mathrm{m})$ of the surface. Sediments adjacent to the St. Matthew-Hall Basin do not seem to contain significant potential source rocks at depths less titan $6,00()$ ieet $(1,800) \mathrm{m})$ or in rocks younger than the Eocene. Moreover, about $10,0(0)$ feet $(3,0)(0) \mathrm{m})$ of sediments are usually necessary to raise the level of maturity in Tertiary shelf basins to the generally accepted threshold of the "peiroleum window." This implies that source rocks of at least Oligocene age or oider would have to be found in parts of the basin to guarantec adequate maturity for petroleum generation. In the adjacent 
Norton Basin, humic, gas-prone kerogen and coal of Tertiary age were most common, but there were little thermogenic hydrocarbons evident. The most likely source of petroleum would have to lie in the pre-Cenozoic rocks for which little available data exist. If hydrocarbons were discovered in the St. Matthew-Hall Basin, they would most likely be dry gas deposits.

Reservoir sands could have been deposited during the major transgression, which defines the unconformity at the base of the Tertiary fill. In addition, coarse-grained flank deposits could have been generated from basement highs that were exposed to wave-base crosion during sea level lowerings. Neritic or transitional marine sands may have been deposited during sea level lowering in the Miocene, as seen in Norton Basin. Reservoir rock characteristics of the basement complex are probably very poor, based upon information from onshore wells and outcrops. Potential reservoirs are more probable in Cenozoic rocks, but hydrocarbons are more likely to have been generated in the basement complex, if they occur at all.

\section{Norton Basin Planning Area}

Norton Basin is a sediment-filled structural depression located in and adjacent to Norton Sound, just south of Nome. Structurally, Norton Basin consists of two subbasins: the Stuart subbasin to the east and the St. Lawrence subbasin to the west. Both are filled with more than 14,000$)$ feet $(4,200 \mathrm{~m})$ of layered Tertiary sedimentary rocks and are separated by a structural high, the Yukon Horst. The basin formed as a result of pull-apart tectonics associated with Late Cretaceous or early Tertiary strikeslip motion along the Kaltag Fault. Continental sedimentation dominated Norton Basin prior to the mid-Eocene, depositing sandstone, silt, and shale overlying Paleozoic(?) basement rocks of phyllite, schist, and marble.

The two subbasins formed during the early Tertiary. During the Eocene, in the western subbasin, fine-grained, micaceous sandstone interbedded with micaceous shale was deposited, whereas in the Stuart subbasin to the east, the Eocene section consists of conglomerates, sands, shales, volcanics, and coal. Sediments of Oligocene age represent several transgressive and regressive episodes. From early to mid-Oligocene, the horst allowed a shallower marine siltstone and sandstone sequence to be deposited in the eastern subbasin, whereas deep-water clastics were deposited in the western subbasin along with shallower marine and nonmarine sediments. Subsidence in response to crustal cooling allowed the deposition of post mid-Oligocene sediments beyond the subbasins. Sediments consist of deltaic to shallow shelf sandstones, siltstones, mudstones, and, in some cases, coal. This subsidence unified deposition from late Oligocene to present within the two subbasins. This sequence of rock is mainly Oligocene and Neogene shallow-marine siltstones, sandstones, and diatomaceous mudstones, with minor coals. Miocene and Pliocene strata consist of diatomaceous mudstones, siltstones, and sandstones. In general, the Neogene strata in both subbasins are similar, but the Paleogene strata in the St. Lawrence subbasin appears finer grained and more marine than the strata of eastern Stuart subbasin.

Exploration began in Norton Basin with the drilling of two COST wells in 1980 and 1982, respectively. The COST No. 1 well was drilled in the St. Lawrence subbasin; the COST No. 2 well was drilled in the Stuart subbasin. Although the COST No. 2 well encountered hows of gas below a depth of $12,00()$ feet $(3,600 \mathrm{~m})$, the shows appeared to be caused by gas trapoed in coal seams. A total of six exploratory $\mathrm{w}$-lls were completed in 1984-85 bctween depths of 3,600$)$ and 10,000 feet $(1,100$ and $3000 \mathrm{~m}$ ) by ARCO and Exxon, with no commercial hydrocarbons accumulations announced.

Anticlines, faulted anticlines, fault traps, and stratigraphic pinch-outs are present in the Norton Basin. Faults and unconformities are present to provide migration routes. The major 
problem facing Norton Basin hydrocarbon production is having a sufficient amount of source rocks with the proper kerogen. COST well data show that the TOC content is generally low for the St. Lawrence subbasin. Although the Stuart subbasin may contain some significant amounts of organic carbon, these are generally associated with coal.

Stratigraphic test well data indicated that sufficient maturity for oil exists below 9,500 feet $(2.900 \mathrm{~m})$ in the western subbasin and 10,600 feet $(3,230 \mathrm{~m})$ in the eastern subbasin. However, none of the wells in the Stuart subbasin were drilled below this depth because the prospective traps occur at shallower depths. If hydrocarbons are present, dry gas and wet gas condensate are considered most likely to occur. In general, the existence of sufficient quantities of mature source rocks appears unlikely and may represent the major problem to the generation of hydrocarbons in the Norton Basin.

Stratigraphic tests show that most of the prospective reservoir rocks are in the Oligocene of the Stuart subbasin, which consists of fluvial to shallow-marine sandstones. Porosities of greater than 13 percent and permeabilities of $1 \mathrm{mD}$ are restricted to depths less than 9,000) feet $(2.700 \mathrm{~m}$ ) (mid-Oligocene or younger) in the castern subbasin. Below this depth, in the "oil window," reservoir quality has been severely reduced by compaction of ductile grains. Although sandstone porosities of greater than 24 percent and permeabilities of $1 \mathrm{mD}$ do occur, they are restricted to depths less than $6.0(1)$ feet $(1.800 \mathrm{~m})$ (late Oligocene or younger) in the western subbasin. Potential reservoirs appear to be sands of the outer shelf to upper slope turbidite deposits that are situated above the "oil window." With sufficient maturity for oil existing below $9.50(0)$ feet $(2,90() \mathrm{m})$, this would be mostly in the Eocene section where, as in the eastern subbasin, porosities are greatly reduced.

\section{Navarin Basin Planning Area}

The Navarin Basin Planning Area consists exclusively of the Navarin Basin which, in turn, consists of three en echelon subbasins informally named the Pinnacle Island, Pervenets, and Navarinsky subbasins, which are filled with more than 36,000 feet $(11,000 \mathrm{~m}$ ) of layered Tertiary sedimentary rock. The subbasins formed as a result of extensional deformation associated with strike-slip motion or oblique subduction of the Kula Plate beneath the North American Plate in the Late Cretaceous to carly Tertiary time. Basin axes trend northwestward and parallel the continental shelf break.

The Pinnacle Island subbasin is the largest and southernmost of three subbasins in the Navarin Basic Planning Arca. It is an asymmetrical graben filled with as much as 36,000 feet $(11,000 \mathrm{~m})$ of Tertiary sediments. The Pervenets subbasin, a symmetrical graben, lies between the Pinnacle Island and Navarinsky subbasins. It contains up to 34,00$)$ fect $(10,400$ $m$ ) of Tertiary sediment. However, the 26,000 foot $(7,900 \mathrm{~m})$ contour defines the limits of the structurally controlled subbasin topography, and above that, the Tertiary fill extends beyond the basement topography, thereby linking the Pervenets and Navarinsky subbasins. The Navarinsky is the northernmost subbasin and is a graben filled with at least $36,0(0)$ feet $(11,000 \mathrm{~m})$ of Tertiary sediments. As with the Pervenets subbasin, the $26,(0)(0$-foot $(7,90) \mathrm{m}$ ) contour defines the limit of the structurally controlled subbasin. Above 26,(0)() feet $(7,925$ $\mathrm{m}$ ), the Pervenets and the Navarinsky subbasins can no longer be structurally differentiated.

The one COST well drilled in the planning area bottomed in Late Cretaceous (Campanian or older) mudstone deposited in an inner neritic to upper bathyal environment, which is overlain by Late Cretaceous (Maastrichtian) nonmarine coal-bearing sediments that were intercalated and intruded by Miocene diabase and basalt sills. The Tertiary-Cretaceous boundary is represented by a diachronous an- 
gular unconformity that commonly marks acoustic basement in the Navarin Basin.

By the late Eocene, movement of the Kula Plate was isolated by subduction at the Aleutian Arc. Subbasin subsidence, in response to structural downdropping, remained active until the late Oligocene. Well data indicate that course-grained deposits possibly exist for moldle Oligocene and late Oligocene erosional events. There also exists a Paleocene nonmarine to marine facies tract that allowed the continuous deposition of marine mudstones and siltstones in the three subbasins throughout most of the Paleogene. In the COST well, Eocene rocks record a marine transgression of (alcareous claystone and mudstone and rapid increases in water depths. By early Oligocene, mid-bathyal water depths were attained and are recorded in the COST well as a largely shaley regressive sequence.

Evidence indicates that sea level lowerings in the middle and late Oligocene, however, exposed older Tertiary and Mesozoic basement highs to wave-base erosion. The result was the deposition of coarser grained material along the subbasin's flanks as indicated by a regressive and then transgressive sandstone sequence in the COST well. Cessation of Kula Plate motion by the early Neogene was followed by crustal cooling, which allowed regional subsidence beyond the structurally defined subbasins. Middle and outer neritic mudstones and sandy mudstones were deposited throughout the Neogene, with a possibility of coarsergrained deposits flanking basement highs that were exposed to wave-base erosion during a sea level lowering in the middle Miocene, as indicated by an angular unconformity in the northwest portion of the basin and a depositional hiatus in the COST well. The PlioPleistucene section, as found in the COST well, comsists of poorly sorted, silty, sandy mudstone and diatomaceous oroe deposited in a midbelf environment.

Through FY 1989. MMS has acquired 54,50() line miles of CDP seismic data in Navarin Basin with a grid spacing density between ( $1 \times 1)$ t) $(8 \times 10)$ mile coverage and single-line coverage. Exploration in the Navarin Basin began in 1983 with the drilling of the Navarin Basin COST No. 1 well to a total depth of $16,4(0)$ feet $(5,000 \mathrm{~m})$ in the northern flank of the Pinnacle Island subbasin. Eight exploratory wells have been drilled, all in 1985, between depths. of $7,(050$ and 13,740 feet $(1,148$ and $4,188 \mathrm{~m})$. No commercial hydrocarbons have been announced.

Stratigraphic test well data indicate the late Eocene and early Oligocene mudstones to be the most favorable source rocks in the Navarin Basin. The TOC for this section, as identified in the COST well, is generally between 1.() and 2.0. Although this stratigraphic sequence thickens in the deeper parts of the subbasins, exploratory wells that were expected to penetrate this inierval did not appear to have encountered economic hydrocarbons. Sections above and below this interval had a TOC value of 0.5 to less than 1.0. Intermittent Paleogene lenses of coal and claystone were marginally mature in a few of the relinquished exploratory wells. A well located on the southeastern tlank of the Pinnacle Island subbasin (Amoco Navy No. 1 well) found thermogenic gas from this interval; however, the gas pressure rapidly declined indicating limited reservoir volume. Other coal occurrences were oxidized, limiting its potential for hydrocarbons. In the Amoco Daniclle No. I well, however, a marginally mature Eocene organic-rich siltstone was rated as having a good potential for hydrocarbons. Mature to marginally mature Early and Late Cretaceous marine and nonmarine clastics were present in all parts of the basin, but significant quantities of a proper source rock were absent. Overall, the information from the relinguished exploratory wells showed generally poor to marginal potential for hydrocarbon generation, and there were no significant indications of oil migration in these wells.

A lack of good reservoir rock seems to be a recurrent problem throughout the Navarin Basin. Late Oligexene to early-to-midale Miocene 
sandstones had represented the only significant potential reservoirs in the COST well. These rocks are Oligocene sandy mudstones and basal sands deposited by the early Tertiary transgressien over Mesozoic basement rocks and coarsegrained deposits flanking basement highs that were deposited during sea level lowerings in the Oligocene and Miocene. No encouraging results were indicated by the data from the relinquished exploratory wells. Neither the Miocene sands nor the basal Tertiary sands, which were believed to be the most prospective plays, showed favorable reservoir characteristics. The coarse-grained deposits flanking the basement highs were deemed not to be fully evaluated.

In some cases, the potential net reservoir sand was as little as 10 feet $(3 \mathrm{~m})$. While porosities approached $25-35$ percent, permeabilities were much lower than anticipated for this porosity range. Permeability measurements taken in the COST well from conventional cores were generally less than $10 \mathrm{mD}$. These low permeabilities result from a combination of factors, such as grain size, clay content, and diagenesis.

Traps found in the basin have included anticlines, faulted anticlines. fault traps, and stratigraphic pinch-outs. To date, no discoveries have been announced. Timing of trap formation and oil generation may have provided important obstacles to oil accumulation. Future exploration may attempt to solve these obstacles by testing traps adjacent to potential source rocks, requiring limited hydrocarbon migration along unconformities, faults, and through permeable strata.

Coarse-grained deposits flanking basement highs are a play concept that was not fully evaluated by these exploratory wells. The early Tertiary-Cretaceous basement complex sampled by the wells includes (1) Early Cretaceous marginal marine fine-grained clastics, (2) Late Cretaceous coal-bearing nonmarine lithologies, (3) Late Cretaceous bathyal fine-grained clastics, and (4) Paleogene deep-water marine fa- cies. Well tests showed no favorable reservoir characteristics for this section.

\section{Hope Basin Planning Area}

The Hope Basin Planning Area is located in the southern Chukchi Sea. Hope Basin proper is a Late Cretaceous (?) to Quaternarv sedimentary basin that, in U.S. waters, lies mostly within the Hope Basin Planning Area, but also extends into the Chukchi Sea Planning Area. Its northern limit is defined by the northweststriking Herald Arch overthrust. It is bounded on the south by an east-west-trending basement ridge (Kotzebue Arch) that parallels the Seward Peninsula and may be an offshore extension of the Kobuk fault zone. The Kotzebue Arch separates Hope Basin from Kotzcbue Basin.

Basement throughout the area probably includes Late Cretaceous or older rocks of the Brooks Range orogen and Devonian or older metasediments similar to those encountered on the Seward Peninsula. Seismic reflection character, refraction velocities, and extrapolation from two wells drilled in the Kotzcbue Sound area suggest that the basin fill is Late Cretaceous (?) to Paleogene marine and nonmarine mudstones, siltstones, sandstones, conglomerates, and volcanics, overlain by Neogene to Quaternary shallow marine, deltaic and glacial sediments, with a combined total thickness in places exceciing 17,000 fect $(5,200 \mathrm{~m})$. Late Cretaceous to early Tertiary sediment fill is draped over the crest of basement highs and fills the intervening troughs. The later Tertiary sediments have filled the basin in subhorizontal layers.

Generally, the basement is faulted into a ridge and trough configuration. The crests of some of these ridges are as close as 2.50() feet $1760 \mathrm{~m})$ from the seafloor, and the basement in the troughs reaches depths of $17,(0)(0)$ feet $(5,20) \mathrm{m})$. These ridges and troughs are defined by norihwest-southeast-trending faults along which the apparent movement has been nomal but may also include some strike-slip 
movement. Faulting is intense throughout most of the basin and appears to have begun in the Late Cretaceous and continued into the Quaternary.

Two exploratory wells, the Nimiuk Point No. I and the Cape Espenberg No, 1, were drilled by Standard Oil of California south of the Kotzebue Arch in Kotzebue Basin in 1974 and 1975. No exploratory or COST wells have been drilled in offshore Hope Basin.

The Kotzebue Sound wells penetrated from $3.5(1) \mathrm{t}(1) 4.0(0)$ feet $(1.070)$ to $1.220 \mathrm{~m})$ of Quaternary and from 2.50() to $4,0(0)$ feet 1760 to $1.220 \mathrm{~m}$ ) of Tertiary sediments that lie on Devonian or older metasedimentary basement. Although these wells were drilled in Selawik Basin, major sequence boundaries can be traced from the wells and correlated across the Kotzebue Arch into Hope Basin, where sediments are thicker. Strata in the Kotzebue Sound wells are not considered significant source beds because sediments contain terrestrially derived, gas-prone, and thermally immature organic material. However, sediments in the deeper Hope Basin may be thermally mature and may have been deposited in a more marine enviromment where potential for source rock formation is greater. Although the kotzebue wells penetrated a sedimentary column with an average sand content for the cotal section of over 50 percent and average porosities over 2.5 percent, these rocks are part of the slightly younger kotzebue Basin, which is separated from Hope Basin by the Kotzebue Arch, and may not represent the older, deeper offshore basin.

Potential traps are faulted anticlines at the (rest of, or adjacent to, the basement ridges and fault traps. However. because of the poor potential for source rocks and the generally thin Tertiary sedimentary section. the prospect for coll accumulation is low.

\section{Chukchi Sea Planning Area}

The Chukchi Sea Planning Area is located on the northwesternmost extension of the Alaska OCS. It contains two geologic provinces, the Chukchi province and part of the Hope Basin province. Resource assessments for the planning area were based only on the Chukchi province. The planning area contains three primary stratigraphic basins: the North Chukchi Basin (Cretaceous-Tertiary), the Central Chukchi Basin (late Paleozoic to late Mesozoic), and the Colville Basin (Early Cretaceous). The Hope Basin (Tertiary) is in the southwest corner of the planning area and is separated by a prominent structural feature, the Herald Arch and the associated Fold and Thrust Belt.

Three stratigraphic sequences are present (Franklinian, Ellesmerian, and Brookian) and represent stages in the tectonic development and depositional history of the area. They appear to be offshore extensions of regional western North Slope stratigraphy. The Franklinian sequence encompasses Cambrian to Middle Devonian rocks that were highly deformed and mildly metamorphosed during a Devonian orogeny that affected much of the North American arctic region. These rocks usually constitute economic basment on the North Slope. The Ellesmerian sequence, Late Devonian to Early Cretaceous in age, is composed onshore of transgressive shallow-shelf marine "arbonate, marine and nonmarine sandstone, and marine shale units derived from a northerly source terrane. Offshore, Ellesmerian lithology is unknown, but sediments in the western part of the province were apparently derived froma westerly source terrane. The Brookian sequence. Early Cretaceous to Tertiary in age, is composed of deep-water io nonmarine, nurthwardly prograding deltaic sedimenti shed from the Brooks Range orogen. Offshore, the Ellesmerian can be subdivided into a lower and upper part by a regional Permian unconformity. The Brookian sequence is also subdivided into lower and upper parts by prominent unconformity of Late (retaceous to early Tertiary age. 
Three major depocenters are iden:ified within the Chukchi province: (1) the Central Chukchi Basin, a north-trending Ellesmerianage depocenter. offshore extension of the Arctic Alaska Basin, containing up to 20,000 feet $(6,100 \mathrm{~m})$ of strata; (2) the Colville Basin, an Early Cretaceous foredeep trough north of the Brook Range orogen containing up to 20,000 feet $(6,000 \mathrm{~m})$ of Brookian deposits; and (3) the North Chukchi Basin, an east-west elongate sag, which contains more than 45,000 feet $(13,700 \mathrm{~m})$ of $\mathrm{B}$ "ookian strata.

The Northem Hope Basin is another depocenter within the planning area south of the Chukchi province. This basin is floored by blockfaulted, pre-Late Cretaceous basement rocks overlain by nonmarine and marine Tertiary clastic rocks reaching a maximum thickness, of 15,000 feet $(4,500 \mathrm{~m})$.

Testonic uplifts and basement platforms recognized in the Chukchi province include the Chukcili Platform in the west, the Arctic Platform in the east, the North Chukchi high in the northeast, and the Herald Arch thrust front in the south. The central and northern parts of the province are extensively faulted by a subparallel series of north-south trending wrench faults. A Late Cretaceous to Tertiary episode of wrench tectonics caps the long and relatively active tectonic history of the province.

No COST wells have been drilled offshore in the Chukchi Sea Planning Area at the time this study was completed. (See ch.3, p. 94, for information on recent exploratory drilling in the Chukchi Sea.) It was necessary to extrapolate stratigraphic relationships into the planning area from existing geological and geophysical data that had been acquired onshore in the adjacent National Petroleum Reserve in Alaska (NPRA).

Geologic data obtained from wells in the western NPRA were used to delineate potential source and reservoir rocks in the eastern part of the Central Chukchi and Colville basins. Strata of the Nori. rhukchi Basin and the western Chukchi province are not exposed in outcrnps onshore and have not been penetrated by onshore wells.

Owing to their high organic carbon content and high percentage of oil-prone kerogen, the best potential source rocks in the western NPRA are the Shublik Formation and the Kingak Shale of the Ellesmerian sequence and the Pebble Shale of the Brookian sequence. In the NPRA, average TOC for the Shublik Formation is 1.3 percent. The TOC values for the Kingak Shale range from 0.9 to 1.20 percent, and for the Pebble Shale, values range southward from 1.6 to 3.2 percent. Vitrinite reflectance values indicate that these rocks increase in thermal maturity and lie below the oil window in the southern part of the province.

At the Tunalik No. 1 well, in the western NPRA, the oil window lies between 2,400 and 8,500 feet $(731$ and $2,590 \mathrm{~m})$ and is above the Pebble shale. Offshore in the Colville Basin, a thermally overmature condition may exist for the Pebble Shale and underlying Ellesmerian rocks. Burial depths of all strata generally increase to the south toward the axis of the eastwest-trending Arctic Alaska Basin onshore, and to the west, toward the north-south Central Chukchi Basin axis offshore. However, present burial depths and inferred subsidence history of the Ellesmerian sequence along the western margin of the Central Chukchi Basin suggest that these straia have not been buried sufficiently deep to render them thermally overmature and, therefore, are in a favorable thermal condition for oil generation.

The most n* ective reservoirs throughout northern fiaska and perhaps also in the Chukchi province are Ellesmerian, namely the Lisburne Group and the Sadlerochit Group, which are oil productive in the Prudhoe Bay area. Potential reservoir facies in the western part of the Chukchi province may exist on the margin of the Central Chukchi Basin where Ellesmerian strata were deposited in a sourceproximal setting on the flank of the Chukchi platform. 
Brookian sequence rocks may also contain potential reservoirs. Sandstones that occur at the base of the Pebble Shale, with porosities of from 16 to 22 percent, form potential reservoirs in the northwestern NPRA. Sandstones of the Nanushuk Group, although predominantly nonporous in the western NPR.4, may have improved reservoir characteristics in the western part of the Chukchi province. In local subbasins offshore, reservoir quality sandstones, equivalent in age to the Colville Group and Sagavanirktok Formation onshore, may have formed by the reworking of underlying Nanushuk strata from structura! highs associated with wre'ch taults.

Both structural and stratigraphic traps are numerous in the planning area. Structura! traps predominate in the Central Chukchi Basin, the North Chukchi Basin, the Fold and Thrust Belt, and the Northern Hope Basin. Stratigraphic traps predominate on the flanks of the Arctic Platform and the Chukchi Platform areas.

The areas with high hydrocarbon potential are along the margins of the northeastern and western Central Chukchi Basin adjacent to the Arctic and Chukchi Platforms. The North Chukchi Basin and the Colville Basin have moderate hydrocarbon potential.

In conclusion, seismic extrapolation of onshore well data from the NPRA indicates that potential Ellesmerian source rocks probably exist off shore, but that they may be overmature beneath the Colville Basin and in deeper parts of the Central Chukchi Basin. The Chukchi Platform may have served as a western source terrane for Ellesmerian sediments and high quality reservoirs could be anticipated in this proximal setting. Brookian rocks are generally lean and gas prone in northwestern Alaska, although source rock characteristics may improve (o) the northwest in a more distal marine setting. Reservoir quality is inferred to be higher in upper Brookian strata because of reworking in an active wrench tectonic setting. Of the three major sequences in the Chukchi province, the Ellesmerian sequence is generally considered to be the most prospective because it contains the major hydrocarbon accumulations on the North Slope of Alaska.

\section{Beaufort Sea Planning Area}

The Beaufort shelf can be divided into two major provinces: (1) a landward area underlain by continental crust called the Arctic Platform and (2) an area near the shelf edge where thick clastic wedges of Cretaceous and Tertiary sediments were deposited upon transitional crust and Mesozoic oceanic crust. The highly faulted boundary between these provinces is termed the Hinge Line. Primary depocenters within these provinces, from west to east, include the Northeast Chukchi Basin, the Nuwuk Basin, the Arctic Platform, the Arctic Basin, the Dinkum Graben, and the Kaktovik Basin.

Acoustic and economic basement on the Arctic Platform consists of a metamorphic complex (Franklinian sequence), which represents the roots of an early Palcozoic orogen. Basement is overlain by Devonian through Early Cretaceous strata (Ellesmerian sequence) and pre-Mid Devonian (Northeast Chukchi Basin sequence). Evaluations of the area show that the strata filling the Northeast Chukchi Basin should be conceptually isolated from the more well-known Ellesmerian sequence.

The No theast Chukchi Basin sequence is a group of rocks that are confined to the western part of the Beaufort shelf. These rocks are structurally isolated within a fault-bounded outlier called the Northeast Chukchi Basin. Seismic ties to onshore wells indicate that the basin fill was deposited and deformed prior to deposition of the Ellesmerian sequence. Because these rocks are much less deformed than rocks of the basement complex east of the Barrow fauit, but predate the traditional Ellesmerian sequence known from the Arctic slope, they are assigned for assessment purposes to a separate group called the Northeast Chukchi Basin. 
The Ellesmerian sequence, deposited in a stable shelf setting, thins and onlaps northward toward the ancient landmass that once existed north of the modern Beaufort continental margin. Ellesmerian sedimentation terminated in Early Cretaceous time with the uplift of the Arctic Platform prior to rifting in the vicinity of the present shelf edge. This uplift produced a regionally extensive Lower Cretaceous unconformity and erosional truncation of Ellesmerian strata across the northern part of the Arctic Platform. The subsequent onset of actual rift displacement produced rift zone grabens, which were filled with Lower Cretaceous sediments (termed the Rift sequence) derived from adjacent highlands. The Barrow Arch formed in response to subsidence of the crust near the rift margin as it cooled and to loading from the formation of the Brooks Range to the south. By the Late Cretaceous, an immense clastic wedge (termed the Brookian sequence) prograding northward from the Brooks Range orogen inundated and spilled over the Barrow Arch into shelf-edge depocenters, such as the Nuwuk and Kaktovik basins, along the newly formed, fault-bounded Beaufort continental margin. Franklinian sequence rocks in the planning area consist mostly of the Neruokpuk Formation, an assemblage of mildly metamorphosed argillite, carbonate, and sandstone.

Seismic data indicate that for the Northeast Basin sequence, threc major stratal units are present: (1) a basal high-velocity unit (possibly carbonate ?) at least 10,000$)$ feet $(3,000 \mathrm{~m})$ thick; (2) an overlying unit of clastic rocks, which ranges up to $25,00()$ feet $(7,60)(0 \mathrm{~m})$ in thickness and contains clinoformal reflections that suggest southeastward progradation of the unit into the basin; and (3) an acoustically well-stratified unit ranging up to $10,(0)(0)$ feet $(3,000) \mathrm{m})$ in thickness that is confined to narrow grabens along the western margin of the Beaufort shelf.

Ellesmerian sequence rocks, in the planning area, include the predominantly clastic wedge of the Endicott Group; the platform carbonates of the Lisburne Group; the Sadlerochit Group, in which marine sands and shales are overlain by fluvial-deltaic deposits of the Ivishak Formation, the primary hydrocarbon-bearing reservoir in the Prudhoe Bay Field; the Shublik Formation, consisting of limes, muds, sands, and phosphatic beds; the Sag River Formation, fine-grained glauconitic sands and interbedded marine shale; the Kingak Formation, a marine shale; and the interbedded shales and fine- to coarse-grained sandstones of the Kuparuk River Formation.

Rift sequence rocks contain clastics that are Early to Middle Cretaceous in age. In areas where well control is available, the Rift sequence includes the Pebble Shale, a marine shale with sandstone interbeds, and the Kemik, Put River, and Point Thomson sandstones. These rocks are termed the Rift sequence because they appear to have been deposited in syntectonic basins developed within an active rift system. The Rift sequence deposits are thickest within grabens that formed early in the course of the rift event (e.g., Dinkum Graben). Within the basal parts of such grabens, the Rift sequence may be Jurassic in age.

Brookian sequence rocks include (1) the prodelta shale facies of the Torok Formation, (2) the fluvial-deltaic facies of the Nanushuk Group, and (3) the deltaic sands and shales of the Colville Group and Sagavanirktok Formation.

Sediment thickness for the Arctic Platform ranges from less than $3,00()$ feet $(900 \mathrm{~m}$ ) at Point Barrow to at least $30,(0)(0)$ feet $(9,00)(0 \mathrm{~m})$ in the Northeast Chukchi Basin west of Barrow. Sediment thickness in the cast-southeasttrending Dinkum Graben approaches 15,0)(0) feet $(4,600 \mathrm{~m})$. The total sedimentary column within the castem portion of the Arctic Platform may exceed 35,000$)$ teet $(10,500 \mathrm{~m})$.

Seaward of the Hinge Line, in the Nuwuk Basin, up to $4(0,0)(0)$ feet $(12,20() \mathrm{m})$ of Brookian clastic sedimentary fill spans the continental basement of the Arctic Platform northward to transitional or oceanic crust of the Arctic 
Basin. Most of the castern Beaufort shelf is underlain by the Kaktovik Basin, which is filled with Brookian sediments. The total thickness of sedimentary rocks within the Kaktovik Basin may exceed $40,00()$ feet $(12,200 \mathrm{~m})$. The principal structural features are large, detached, compressional folds and zones of en echelon folds, which intervene between faultbounded basins.

Sediment thickness in the southern parts of the decp-water Arctic Basin range from 20,000 to 33,000 feet 16,100$)$ to $10,060 \mathrm{~m})$. These sediments rest directly upon oceanic crust. Diapiric folds and ridges are common in the deep Arctic Basin east of $145^{\circ} \mathrm{W}$. longitude.

The North Slope area has been explored for hydrocarbons since 1944, when the Department of the Navy began drilling exploratory tests at several localities in the central and northernmost parts of the Arctic coastal plain. This work led to the discovery of several subcommercial oil and gas fields. Privately funded exploration elsewhere on the coastal plain led to the discovery of the supergiant Prudhoe Bay field in 1968. This ficld contains remaining recoverable reserves in excess of $5 \mathrm{Bbbl}$ of oil (original reserves, $10 \mathrm{Bbbl}$ ) and $26 \mathrm{Tcf}$ of gas. It sparked oil development in northern Alaska and afforded construction of an essential pipeline transportation system from the field to an ice-free port in southern Alaska. Because of the existence of this infrastructure, satellite accumulations in the vicinity of Prudhoc Bay, which would otherwise be considered subcommercial (ranging from 0.3 to $1.0 \mathrm{Bbbl}$ ), are now being brought into production.

Since 1981, there have been 21 exploratory wells drilled on Federal offshore acreage. Nine of these wells (drilled on Beechy Point, Hammerhead, Tern Island, Sandpiper, and Seal Island prospects) have been determined as pro(lucible in accordance with 30) CFR 250.11. Producible means that production of oil is sufficient to yicld a monetary return in excess of the well's operating costs. It does not mean that commercial quantities have been found because no consideration is given to the investment.

The Seal Island discovery, 12 miles $(20 \mathrm{~km})$ northwest of Prudhoe Bay, was announced by Shell in early 1984 , and appears to extend from State to Federal waters. As of 1987, total recoverable reserves in the Seal lsland structure are presently estimated at $300 \mathrm{MMbbl}$. Shell's Sandpiper Well (Y-0370 No. 1) tested 5002,500 barrels of oil per day (BOPD) and 18.5 million cubic feet of gas per day (MMcfd) of gas from the Sadlerochit Group.

Sohio completed a test on the Mukluk structure in 1984, and tested only a small amount of gas and 146 barrels of oil from a sand at the base of the Pebble Shale. The well was plugged and abandoned at a cost of approximately $\$ 140$ million. The Mukluk structure is composed of scaling surfaces and a trapping configuration similar to this Prudhoc Bay structure.

Excellent source beds are thought to be present at levels of thermal maturity adequate for oil generation and expulsion in all parts of the Beaufort continental shelf within the planning area. The Pebble Shale (Rift sequence) contains an average TOC of 5.4 percent, and the Kingak Formation (Ellesmerian sequence) contains a TOC of 1.9 percent. Shales of the Shublik Formation (Ellesmerian sequence) are also regarded as good potential source beds. However. Sadlerochit, Lisburne, and Endicott shales are regarded as somewhat lean and may be gas prone. In the Nuwuk and Kaktovik basins, Ellesmerian rocks are absent and Rift sequence strata lic below $23,0(0)$ feet $(7,00) \mathrm{m})$ and are probably overmature. In these basins, source rocks must be sought in the Brookian sequence. Geochemical data from wells on the castern Arctic Platform (Exxon Point Thomson and Mobil West Staines) show that Brookian shales range from non-source to fair-source potential.

All commercial North Slope oil accumulations are lodged in Ellesmerian sequence res- 
ervoil formations. These include Prudhoe Bay, Lisburne, Endicott, Kuparuk, and Milne Point Fields. Any part of the Arctic Platform where these rocks are preserved is considered highly prospective. The most prolific reservoir formation of the Ellesmerian sequence is the Ivishak Formation, where porosities can rise to 30 percent and permeabilities may exceed several darcys. Also, carbonates of the Lisburne Group produce at Prudhoc Bay with porosities averaging 1()-15 percent. Known accumulations are trapped by a complex composite of sealing surfaces, including faults, and truncation at regional unconformities such as that associated with the major Lower Cretaceous erosional event. The northernmost parts of the Arctic Platform are less prospective because of the absence of Ellesmerian formations, but they contain rift zone grabens within which reservoir rocks deposited as part of the Rift sequence may be present. Within the Nuwuk and Kaktovik basins, Ellesmerian reservoir strata are either absent or lic at depths exceeding $20.0(0)$ tect $(6,0)(0) \mathrm{m})$.

Numerous structural and stratigraphic traps exist within the thick Brookian clastic wedge in the Nuwuk and Kaktovik basins. Any potential reservoir formations in this area, such as sunds of the Colville Group and Sagavanirktok Formation, were most likely deposited in a deltuic or prodeltaic setting, suggesting that individual accumulations may be small because of reservoir lenticularity. The same has been commonly, but not universally, true in analogous geological provinces, such as the Mackenzic Delta area of the Canadian Beaufort shelf. However, the largest known accumulation in that area, the Amauligak Field, is estimated by (julf Canada io contain approximately 50() MMbol of recoverable oil. The discovery was made in the Kugmallit Formation in a listric fault block. In the Brookian sequence in the L.S. Beaufort, rotational folds associated with listric faulting are the most attractive targets in the Nuwuk Basin, whereas compressional folds and fault traps form the most prevalent trap lypes in the Kaktovik Basin.

\section{Resource Estimates for the Alaska OCS Region}

Table 1-3 (p. 31 \& p. 32) presents the current undiscovered economically recoverable oil and gas resource estimates for the Alaska OCS planning arcas.

\section{Atlantic OCS Region}

The Atlantic OCS Region is divided into four planning areas for the purpose of OCS oil and gas leasing. The region extends from of fshore Maine to the Florida Keys. Figure 1-3 (p. 33) depicts the location of the Atlantic OCS planning areas and their basins and depocenters.

\section{Geology and Petroleum Potential of the Atlantic OCS Region}

\section{North Atlantic Planning Area}

The Georges Bank Basin is the major geologic feature of the North Atlantic Planning Area. The basin is an elongated east-west-trending complex of depressions, or subbasins, altogether approximately 350 miles $(560 \mathrm{~km})$ long and 120 miles $(190 \mathrm{~km})$ wide. The total sedimentary section exceeds 32,000 feet in the main subbasin and is subdivided into synrift and postrift rocks. The younger postrift section is as much as 23,0()() feet thick, and the older synrift section is extremely variable in thickness; where it is associated with large grabens, it may be more than $15,(0)(0)$ feet. The synrift sediments are Triassic and Early Jurassic clastic, volcaniclastic, fluvio-lacustrine, and cvaporitic deposits. These deposits were preserved in and above krabens that formed in crystalline and metasedimentary basement rocks as a consequence of the rifting process when Norih America and northwest Africa scparated from one another 2()() million years ago.

The postrift sedimentary section consists of siliciclastic and carbonate rocks. The latter are shallow-water platform limestones, which pre- 
Table 1-3. Estimates of undiscovered economically recoverable oil and gas resources in the Alaska OCS Region as of January 1990

[Oil and BOE in billion barrels; gas in trillion cubic feet]

\begin{tabular}{|c|c|c|c|c|c|c|c|c|c|c|}
\hline \multirow[b]{2}{*}{ Planning Area } & \multicolumn{3}{|c|}{ Conditlonal oll } & \multicolumn{3}{|c|}{ Conditional gas } & \multirow{2}{*}{$\underset{(1)}{M P} H C$} & \multirow{2}{*}{$\begin{array}{l}\text { Risked } \\
\text { mean } \\
\text { oll }\end{array}$} & \multirow{2}{*}{$\begin{array}{c}\text { Rlsked } \\
\text { mean } \\
\text { gas }\end{array}$} & \multirow{2}{*}{$\begin{array}{l}\text { Risked } \\
\text { BOE(2) }\end{array}$} \\
\hline & $\begin{array}{l}95 \% \\
\text { case }\end{array}$ & $\begin{array}{l}\text { Mean } \\
\text { case }\end{array}$ & $\begin{array}{l}5 \% \\
\text { case }\end{array}$ & $\begin{array}{l}95 \% \\
\text { case }\end{array}$ & $\begin{array}{c}\text { Mean } \\
\text { case }\end{array}$ & $\begin{array}{l}5 \% \\
\text { case }\end{array}$ & & & & \\
\hline \multicolumn{11}{|l|}{$\begin{array}{l}\text { Arctlc Subreglon: } \\
\text { Beautort Sea(1) }\end{array}$} \\
\hline Leased and unleased & 0.58 & 1.66 & 4.69 & 0.00 & 0.00 & 0.00 & 0.23 & 0.38 & 0.00 & 0.38 \\
\hline Unleased & 0.43 & 1.45 & 4.19 & 0.00 & 0.00 & 0.00 & 0.16 & 0.24 & 0.00 & 0.24 \\
\hline Leased & 0.54 & 0.94 & 1.82 & 0.00 & 0.00 & & & 0.14 & & \\
\hline \multicolumn{11}{|l|}{ Chukchi Sea(1) } \\
\hline Leased and unleased & 1.19 & 5.96 & 13.10 & 0.00 & 0.00 & 0.00 & 0.23 & 1.36 & 0.00 & 1.36 \\
\hline Unleased & 1.11 & 4.16 & 9.14 & 0.00 & 0.00 & 0.00 & 0.21 & 0.88 & 0.00 & 0.88 \\
\hline Leased & 0.96 & 2.65 & 5.53 & 0.00 & 0.00 & 0.00 & 0.17 & 0.46 & 0.00 & 0.46 \\
\hline \multicolumn{11}{|l|}{ Hope Basin } \\
\hline Leased and unleased & 0.20 & 0.50 & 1.44 & 0.00 & 0.00 & 0.00 & $<0.01$ & $\star \star$ & 0.00 & $\star$ \\
\hline Unleased & 0.20 & 0.50 & 1.44 & 0.00 & 0.00 & 0.00 & $<0.01$ & $\star$ & 0.00 & $\star$ \\
\hline Leased & 0.00 & 0.00 & 0.00 & 0.00 & 0.00 & 0.00 & 0.00 & 0.00 & 0.00 & 0.00 \\
\hline \multicolumn{11}{|l|}{$\begin{array}{l}\text { Berlng Sea Subreglon: } \\
\text { Norton Basin }\end{array}$} \\
\hline Leased and unleased & N/A & 0.58 & N/A & 0.00 & 0.00 & 0.00 & $<0.01$ & $\star$ & 0.00 & $\star$ \\
\hline Unleased & $N / A$ & 0.51 & $N / A$ & 0.00 & 0.00 & 0.00 & $<0.01$ & * & 0.00 & $\star$ \\
\hline Leased & $N / A$ & 0.17 & $N / A$ & 0.00 & 0.00 & 0.00 & $<0.01$ & $\star$ & 0.00 & $\star$ \\
\hline \multicolumn{11}{|l|}{ Navarin Basin } \\
\hline Leased and unleased & 0.17 & 1.14 & 4.95 & 0.00 & 0.00 & 0.00 & 0.03 & 0.03 & 0.00 & 0.03 \\
\hline Unleased & 0.12 & 0.90 & 4.32 & 0.00 & 0.00 & 0.00 & 0.03 & 0.03 & 0.00 & 0.03 \\
\hline Leased & 0.05 & 0.33 & 1.03 & 0.00 & 0.00 & 0.00 & 0.03 & 0.01 & 0.00 & 0.01 \\
\hline \multicolumn{11}{|l|}{ St. Matthew-Hall } \\
\hline Leased and unleased & $\star$ & $\star$ & $\star$ & $\star$ & $\star$ & $\star$ & * & $\star$ & $\star$ & $\star$ \\
\hline Unieased & $\star$ & $\star$ & $\star$ & $\star$ & $\star$ & $\star$ & $\star$ & $\star$ & $\star$ & $\star$ \\
\hline Leased & 0.00 & 0.00 & 0.00 & 0.00 & 0.00 & 0.00 & 0.00 & 0.00 & 0.00 & 0.00 \\
\hline \multicolumn{11}{|l|}{ Aleutian Basin } \\
\hline Leased and unleased & $\star$ & $\star$ & $\star$ & $\star$ & * & $\star$ & $\star$ & $\star$ & $\star$ & * \\
\hline Unleased & * & $\star$ & $\star$ & $\star$ & $\star$ & $\star$ & $\star$ & $\star$ & $\star$ & $\star$ \\
\hline Leased & 0.00 & 0.00 & 0.00 & 0.00 & 0.00 & 0.00 & 0.00 & 0.00 & 0.00 & 0.00 \\
\hline \multicolumn{11}{|l|}{ Bowers Basin } \\
\hline Leased and unleased & * & $\star$ & $\star$ & $\star$ & $\star$ & * & $*$ & $\star$ & * & * \\
\hline Unieased & $\star$ & $\star$ & $\star$ & $\star$ & * & $\star$ & $\star$ & $\star$ & $\star$ & $\star$ \\
\hline Leased & 0.00 & 0.00 & 0.00 & 0.00 & 0.00 & 0.00 & 0.00 & 0.00 & 0.00 & 0.00 \\
\hline \multicolumn{11}{|l|}{ Aleutian Arc } \\
\hline Leased and unleased & $\star$ & $\star$ & $\star$ & * & $\star$ & * & $\star$ & $\star$ & $\star$ & * \\
\hline Unleased & $\star$ & $\star$ & $\star$ & $\star$ & $\star$ & $\star$ & $\star$ & $\star$ & $\star$ & $\star$ \\
\hline Leased & 0.00 & 0.00 & 0.00 & 0.00 & 0.00 & 0.00 & 0.00 & 0.00 & 0.00 & 0.00 \\
\hline \multicolumn{11}{|l|}{ St. George Basin } \\
\hline Leased and unleased & 0.17 & 0.39 & 0.91 & 0.00 & 0.00 & 0.00 & 0.02 & 0.01 & 0.00 & 0.01 \\
\hline Unleased & 0.15 & 0.38 & 0.91 & 0.00 & 0.00 & 0.00 & 0.02 & 0.01 & 0.00 & 0.01 \\
\hline Leased & $N / A$ & 0.11 & $N / A$ & 0.00 & 0.00 & 0.00 & $\star$ & $\star$ & 0.00 & $\star$ \\
\hline \multicolumn{11}{|l|}{ North Aleutian Basin } \\
\hline Leased and unleased & 0.17 & 0.61 & 2.08 & 0.00 & 0.00 & 0.00 & 0.02 & 0.01 & 0.00 & 0.01 \\
\hline Unleased & 0.17 & 0.61 & 2.08 & 0.00 & 0.00 & 0.00 & 0.02 & 0.01 & 0.00 & 0.01 \\
\hline Leased & 0.00 & 0.00 & 0.00 & 0.00 & 0.00 & $c .00$ & 0.00 & 0.00 & 0.00 & 0.00 \\
\hline
\end{tabular}


Table 1-3. Estimates of undiscovered economically recoverable oil and gas resources in the Alaska OCS Region as of January 1990-continued

[Oil and BOE in billion barrels; gas in trillion cubic feet]

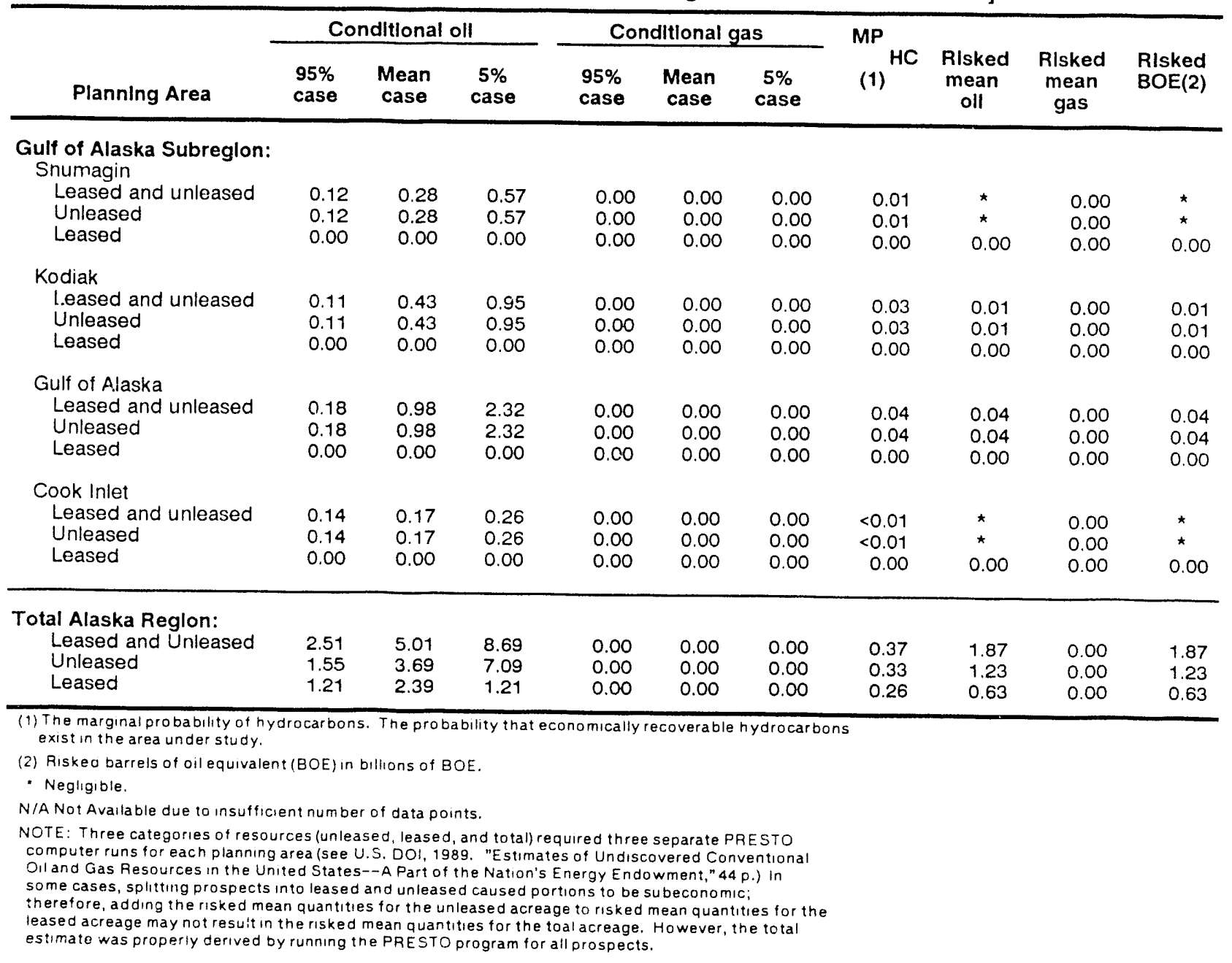

dominate among the deeper postrift rocks and also in the seaward portion of the carliest Cretaceous Continental Shelf. Siliciclastic rocks are interbedded mid-Cretaceous through Jurassic shales and siltstones with minor sandstones and limestones. Above the mid-Cretaceous, rocks are mostly shales and mudstones with subordinate sands, limes, and inarls.

Exploration for petroleum in the Georges Bank Basin began in April 1976 when the first of two COST wells was spudded. Sec table 1-4 (p. 34) for a detailed listing of $\cos T$ wells drilled on the Atlantic OCS. Eight additional North Atlantic wells were drilled by industry in 1981-82 to depths between 14,000 and $20,00()$ feet $(4,266 \mathrm{~m}$ and $6,100 \mathrm{~m})$, all of which were dry. (See ch. 3 for more information on exploratory wells drilled on the Atlantic OCS.)

The North Atlantic Planning Area can be divided into three areas of hydrocarbon potential: the Georges Bank Basin (a zone of thick sediments centered on, and approximately parallel (1), the modern shelf break), the Gulf of Maine, 


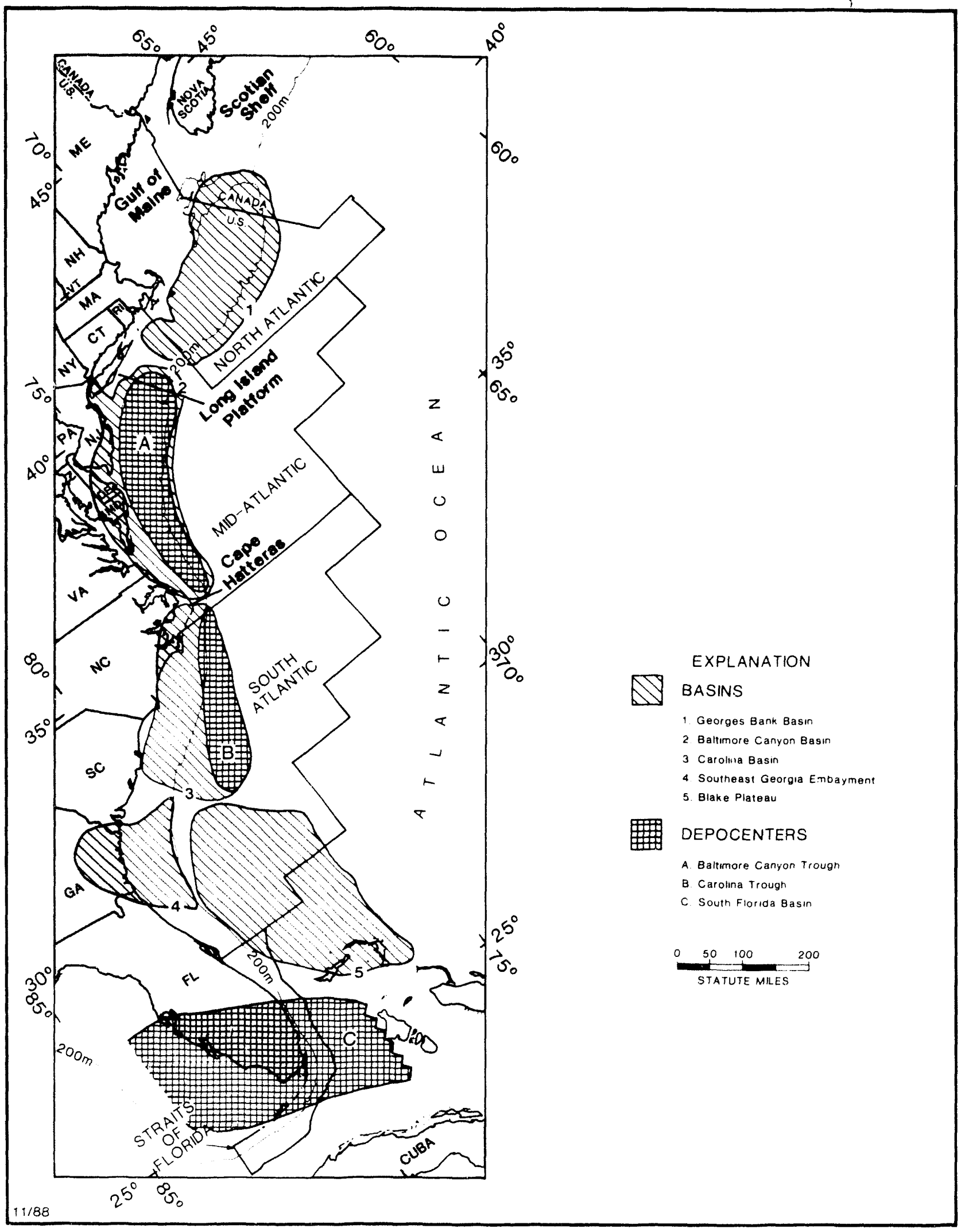

Figure 1-4. Atlantic OCS Region planning areas, basins, and depocenters. 
Table 1-4. COST wells drilled on the Atlantic OCS

\begin{tabular}{|c|c|c|c|c|c|c|}
\hline $\begin{array}{l}\text { Planning area/ } \\
\text { well number }\end{array}$ & $\begin{array}{l}\text { Lease/block } \\
\text { number }\end{array}$ & Operator & $\begin{array}{l}\text { Spud } \\
\text { date }\end{array}$ & $\begin{array}{c}\text { Total } \\
\text { depth }(f t)\end{array}$ & $\begin{array}{c}\text { Completion } \\
\text { date }\end{array}$ & $\begin{array}{c}\text { Report } \\
\text { number }\end{array}$ \\
\hline $\begin{array}{l}\text { North Atlantic } \\
G-1\end{array}$ & $\begin{array}{l}\text { NK 19-11 } \\
\text { Block } 79\end{array}$ & $\begin{array}{l}\text { Ocean } \\
\text { Production }\end{array}$ & $04 / 06 / 76$ & 16,071 & $07 / 27 / 76$ & $\begin{array}{l}\text { OCS }-0003 \\
\text { OCS-0059 }\end{array}$ \\
\hline $\begin{array}{l}\text { North Atlantic } \\
\text { G-2 }\end{array}$ & $\begin{array}{l}\text { NK 19-12 } \\
\text { Block } 141\end{array}$ & $\begin{array}{l}\text { Ocean } \\
\text { Production }\end{array}$ & $01 / 06 / 77$ & 21,872 & $08 / 06 / 77$ & $\begin{array}{l}\text { OCS }-0004 \\
\text { OCS-0059 }\end{array}$ \\
\hline $\begin{array}{l}\text { Mid-Allantic } \\
\text { B-2 }\end{array}$ & $\begin{array}{l}\text { NJ 18-3 } \\
\text { Block } 594\end{array}$ & $\begin{array}{l}\text { Ocean } \\
\text { Production }\end{array}$ & $12 / 14 / 75$ & 16,043 & $03 / 28 / 76$ & $\begin{array}{l}\text { OCS-0001 } \\
\text { OCS-0053 }\end{array}$ \\
\hline $\begin{array}{l}\text { Mid-Atlantic } \\
\text { B-3 }\end{array}$ & $\begin{array}{l}\text { NJ 18-6 } \\
\text { Block } 66\end{array}$ & Chevron & $10 / 09 / 78$ & 15,820 & $01 / 24 / 79$ & $\begin{array}{l}\text { OCS-0002 } \\
\text { OCS-0058 }\end{array}$ \\
\hline $\begin{array}{l}\text { South Atlantic } \\
\text { GE-1 }\end{array}$ & $\begin{array}{l}\text { NH 17-5 } \\
\text { Block } 387\end{array}$ & $\begin{array}{l}\text { Ocean } \\
\text { Production }\end{array}$ & $02 / 24 / 77$ & 13,254 & $06 / 15 / 77$ & $\begin{array}{l}\text { OCS-0005 } \\
\text { OCS-0006 }\end{array}$ \\
\hline
\end{tabular}

and the deep-water area immediately seaward of the Georges Bank Basin. Because of limited geological and geophysical data, the petroleum potential of the Gulf of Maine and deep-water areas is not well known. The most prospective part of the planning area is within the Georges Bank Basin. This area includes a Jurassic-earliest Cretaceous paleoshelf edge carbonate buildup. This shelf-edge complex is discontinuously distributed in the subsurface all along the North American Atlantic margin and trends parallel to the present shelf break throughout the planning area. The buildup in the Georges Bank area has not yet been drilled. Samples from equivalent strata to the northeast (Scotian shelf) and southwest (Baltimore Canyon trough) have good porosity and permeability, but lack significant hydrocarbon accumulations. In addition to porous reefal carbonates, traps associated with the buildup include draped stuctures overlying high areas of the buildup, stratigraphic traps, and fault closures.

Potential source rocks in a number of the wells drilled on the shelf have been analyzed. Source rock quality is in the poor-to-fair range with low total organic carbon (TOC) abundances. Most of the kerogen in the thermally mature sediments is of terrestrial origin and is considered gas prone. The onset of thermal generation, as indicated in the Shell Block 410 well, appears to about 10,000 feet $(3,048 \mathrm{~m})$ with peak generation occurring at about 12,600 feet $(3,840 \mathrm{~m})$.

In the explored part of the basin, thermally mature rocks tend to be tight, with porosities ordinarily less than 5 percent and permeabilities less than $20 \mathrm{mD}$. Sandstone as a distinct lithology is largely absent. Log analyses indicate that porous, reservoir quality clastic rocks are found above 10,000 feet $(3,048 \mathrm{~m})$ in thermally immature sediments. Therefore, upward migration paths are necessary for hydrocarbon accumulation. So far, only minor gas shows have been encountered in these more shallow, porous rocks. However, the untested limestones of the Georges Bank paleoshelf-edge buildup may also be porous, owing to secondary porosity development.

The next most prospective part of the planning area is underlain by the Triassic-Early Jurassic rift basins. These are on the shoreward flanks of the subbasins and immediately landward of the subbasins, extending east-west across the Gulf of Maine. The rift basins of the North Atlantic Planning Area are untested by drilling. However, such basins have been drilled onshore on the coastal plain of the mid- 
Atlantic States, where they have yielded shows of oil and gas. Recent worldwide studies of rift basins suggest that ancient lacustrine (lake) sediments can form good oil source rocks.

The final subarea, on the continental slope in deep water seaward of Georges Bank Basin, is the least known. Except for very shallow stratigraphic drilling, such as the Deep Sea Drilling Project, there are no wells. Potential source rocks are marine shales of Jurassic and lowermost Cretaceous age, which may produce oil. Potential reservoirs may be in turbidite sands, and traps may be structural and stratigraphic.

\section{Mid-Atlantic Planning Area}

The Baltimore Canyon Basin is the major geologic feature of the Mid-Atlantic Planning Area. The basin is an elongated northeast-trending depression averaging 125 miles $(200 \mathrm{~km}$ ) in width and extending some $4(0)$ miles $(640 \mathrm{~km}$ ) in length. Sediment thickness ranges from $3(0,0)(0)$ feet to 40,000$)$ feet $(9,000-12,000 \mathrm{~m})$ in the deeper subbasins. Sediments range in age from Triassic to Holocene, with most of the section being of Jurassic age. As with the North Atlantic, Triassic and Early Jurassic sediments are primarily clastic, volcaniclastic, lacustrine, and evaporitic synrift rocks deposited in rift basins followed by a thick Jurassic-Cretaceous section of clastics and carbonates, overlain by a thinner Cenozoic section of sands, muds, limes, and marls. Areal distributions and relations among the units are similar to those of Georges Bank Basin.

The first deep stratigraphic test well (COST B-2) in the Mid-Atlantic Planning Area was drilled in 1975 and 1976. The COST B-3 well was completed in 1979 and was followed by 32 industry exploratory wells.

Five of eight wells drilled on a single large structure the Texaco-Tenneco structure Hudson (anyon Blocks 598 and 642) discovered significant quantities of gas and light oil. Individual test results of gas ranged from less than 1 million to $18.9 \mathrm{MMc}$ (t). The best reservoir sands were between $12,0(0)$ and $14,50(0)$ feet $(3,600-4,000 \mathrm{~m})$ in the Upper Jurassic. From a shallower zone around 8,300 feet $(2,540 \mathrm{~m}), 630)$ BOPD were tested. However, calculated petroleum reserves were insufficient to justify development. If this discovery were onshore or in shallow water near shore, it would now be in production. The other Baltimore Canyon industry wells failed to encounter significant hydrocarbons. However, the COST B3 well, located about 30 miles southwest of the Texaco-Tenneco structure, encountered a show of gas from a 6-foot zone below $15,(0)()$ fect $(4,500 \mathrm{~m})$.

Salt deposition, probably near the beginning of the postrift phase, followed by loading with younger sediments, resulted in scattered occurrences of deep-seated diapirism. Igneous intrusives are sparsely distributed throughout the planning area; one of the largest of these, the Great Stone Dome, is believed to be a batholith with many dikes and sills. Drilling on this structure encountered sandstones and th in limestone reservoir rocks of Jurassic and Lower Cretaceous age. Reservoir quality was variable. Shales were primarily terrestrial in origin and contained low levels of organic matter. Also, any potential reservoirs lacked adequate seals. All wells were dry.

Among the most prospective parts of the Mid-Atlantic Planning Area is the zone of thick sediments beneath the modern Outer Continental Shelf. During the Jurassic, the structural configuration of the shelf and the basin itself developed, and the shelf edge became a site for rectal growth and carbonate bioclastic accumulation that ended in the Early Cretaceous, probably because of climatic or custatic changes. Three wells, drilled by Shell, tested the carbonate buildup and associated limestone facies. Rock units encountered in the wells consist of a lime-stone platform and a shelfedge recfal buildup. Porous carbonates with overlying shales form good rescrvoir rock and top seals, respectively. However, no hydrocis bons were encountered perhaps owing to a lick 
of deeper lying, organic-rich source rocks in the immediate vicinity. A fourth well, drilled by shell on trend with the carbonate buildup, did not penetrate limestone, but encountered continentally derived clastics of the ancestral Delaware River delta system. Some of the rocks were organically rich enough to be potential source beds; however, there was a lack of adequate reservoir rock. All four wells were plugged and abandoned without recording significant hydrocarbon shows.

Potential source rocks in a number of wells have been analyzed. Source rock quality is gencrally in the poor to good range. Most of the kerogen is terrestrial Type 111 at thermally mature depths, indicating that most generated h: drocarbons would be gas rather than oil. Originally, it was presumed that the potential for oil would increase seaward where the proportion of algal, oil-prone kerogen would be expected to increase. However. organic matter in Shells four wells was terrestrial in origin, again indicating gas rather than oil. In the sedimentary section of the Baltimore Canyon Basin that is considered thermally mature for hydrocarbon generation below 10,000 fect (3.(2)(1) $\mathrm{m})$. the source rock shales tend to be lean, with total organic carbon (TOC) usually less than 0.6 percent. However, Jurassic and Early Cretaceous marine shales immediately seaward of the ancient recfal buildup have not been tested by drilling. These may be organically richer and may contain more sapropellic kerogens than the shales of the shelf. The rift basins are also untested. They may also contain richer, osl-producing organic source matter.

\section{South Atlantic Planning Area}

The South Atlantic Planning Area contuins three major basins: the Southeast Georgia Embayment, the Carolina Basin, and the Blake Plateau Basin. The Southeast Georgia Embayment is an east-plunging depression approximately 120 miles $119(1) \mathrm{km}$ ) long and $\mathrm{x}(1)$ miles $1130 \mathrm{~km}$ ) wide in which the sedinentary sec-

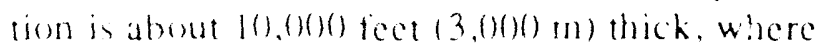
exploration drilling has occurred: seaward, this thickness increases. The Carolina Basin, which includes the Carolina Trough, is approximately 225 miles $(360 \mathrm{~km})$ long and 150 miles (24) $\mathrm{km})$ wide and contains, along its axis, as much as $40,(0)()$ feet $(12,20) \mathrm{m})$ of sedimentary fill. The Blake Plateau Basin is the largest sedimentary basin off the U.S. cast coast, approximately 32() miles $(515 \mathrm{~km})$ long and 175 miles $(280 \mathrm{~km})$ wide and contains up to $4(0,0)(0) \mathrm{fect}$ $(12.0(0)(\mathrm{m})$ of sediment.

The petroleum potential of the South Atlantic Planning Area is difficult to assess because of the lack of exploratory well data apart from that of the Southeast Georgia Embayment. The first deep well in the planning area was the COST GE-1 well, completed in 1977, in the Southeast Georgia Embayment. This well was followed by six unsuccessful exploratory wells, also drilled in the Southeast Georgia Embayment in 1979 and in 1980. Depths ranged from 7,()()() to 13,254 feet $(2,134-4$, () 4 () $\mathrm{m})$. Although most Atlantic OCS exploration targets are of Jurassic age, sediments of Jurassic age are absent in this basin. The lower, marginally thermally mature part of this basin is largely composed of Cretaceous continental clastics with poor source rock characteristics. These sediments rest inconformably on Paleozoic basement. Sediments are flat lying (marine deposits) and include few large structural traps. The petroleum potential at the Southeast Georgia Embayment is poor.

The Carolina Basin appears to have good potential for hydrocarbon generation and entrapment. Although the basin has not been drilled, seismic correlations suggest that this basin is genlogically similar to the Baltimore (anyon Basin and Georges Bank Basin. The rocks appear to range in age from Triassic to Holocene, with most of the sediments being Jurassic. Triassic and Early Jurassic sediments are probably continental clastics deposited during continental rifting. Jurassic rocks are probably limestones, dolomites, and siliciclastics; the carbonates likely grade landward into clastics. Cretaceous and younger sediments are believed wh be mostly and and shate, with carbonates 
occurring in lesser quantities. The basin has sufficient sediment thickness to indicate a con siderable interval of thermal maturity. It also has a number of trapping mechanisms, and the sedimentary section may include source rocks. Seismic interpretations indicate that a thick regional salt bed, deposited immediately after rifting ceased, was deformed by sediment loading and produced a number of diapirs on the seaward edge of the basin. A northeast-trending group of growth faults on the continental slope is associated with salt flow, producing other potential traps. Other faults are common within and on the margins of the basin.

The Blake Plateau Basin may have possibilities for accumulations of hydrocarbons. There are no exploratory wells in the basin, but inferences of probable lithologies have been made from seismic facies analysis and peripheral Deep Sea Drilling Project (DSDP) well data. Most of the sediments in the basin are believed to be limestones and dolomites. More than half the total thickness is Jurassic (and probable Late Triassic) in age with the remainder being Cretaceous overlain by a thin Tertiary section. The basin is large in area and deep enough to contain a thick, thermally mature section. The section is probably totally marine and theicfore generally oil prone. Seismic interpretation indicates that strata appear unaffected by faulting or deformation, suggesting that the basin has been tectonically stable since Lower Jurassic time. Structures are very large in area '"lt have low relict.

\section{Straits of Florida Planning Area}

The Straits of Florida Planning Area is on the Continenal Shelf offshore from the southern half of the State, west of Bahamian waters in the Atlantic, and north of Cuban waters in the Florida Straits. The southern part of the area is south of the Floridla Keys and extends west 16) Dry Tortugas. The planning area contains a small part of the Blake Plateau Basin and part of the South Florida-Bahama Basin. encompassing an area of approximately $1.5,50(0)$ square miles (40.1(10) sq $\mathrm{km})$.
Sediment thickness is variable throughout the region, achieving a maximum of about $3(0,0)(0)$ feet $(9,100 \mathrm{~m})$. The dominant rock type is carbonate. The post-Triassic and post-Jurassic (o) Quaternary sections are almost totally chalks, limestones, dolomites, and unconsolidated lime muds of shallow-water origin. Evaporites and chert are also present in lesser quantities. The oldest sedimentary rocks, arkosic sandstones and volcaniclastics of probable Triassic and Jurassic age, were deposited in grabens and half grabens, which developed in Paleozoic crystalline basement as a consequence of rifting. The older sedimentary rocks are separated from the overlying Jurassic Wood River Formation and younger carbonates, including the Cretaceous Sunniland Formation, by a prominent regional unconformity.

Commercial hydrocarbon accumulations have not been discovered in the Florida Straits Planning Area, but production occurs in periphcral areas - the north coast of Cuba and Sunniland Trend in Florida. The Sunniland fields produce from carbonate reservoirs of the Sunniland Formation, and the oil and gas may have originated from carbonate, rather than shale, source rocks. The Sunniland occurs at depths of $11,(0)(0)-12,(0)()$ feet $(3,400)-3,600) \mathrm{m})$. Sunniland reservoir rocks formed as mounds of recfal debris and have porosities as high as 35 percent. Source rocks for the Sunniland may be algal-rich limestones in the lower part of the formation.

Three wells have been drilled in the planning area. These wells were drilled in 1960-61 by Gulf and Chevron on leases resulting from Sale No. 5 in 1959. They are located south of and between the Dry Tortugas and Marquesas key. One well, the Gulf No. I Marquesas Block $2 x$, encountered oil shows in Sumilandequivalent rocks. At least 17 other wells have been drilled adjacent to or near the planning area, including several holes telow $12,0(0)$ feet $(3,6,50 \mathrm{~m})$ in or near the Florida Keys. Of these 17 wells, the Gulf No. I State 826 Y sested 1.5 barrels of $22^{\circ}$ API gravity oil in Sumnilandequivalent rocks, and the Repuolic Robinson 
No. I State 11-F also encountered oil and gas shows in Sunniland-equivalent rocks.

\section{Resource Estimates for the Atlantic OCS Region}

Table $1-5$ (p. 39) presents the current undiscovered economically recoverable oil and gas resource estimates for Atlantic OCS planning areas.

\section{Gulf of Mexico OCS Region}

The Gulf of Mexico OCS Region is divided into three planning areas for the purpose of OCS oil and gas leasing. The region lies offshore the States of Texas, Louisiana, Mississippi, Alabama, and Florida. Geologically, the Gulf of Mexico OCS planning areas contain a complex of basins, depocenters, and structural uplifts. Figures 1.4 and $1-5$ (p. 40 and p. 41) show the basins, depocenters, and major structural feature in the northern Gulf of Mexico. Table 1-6 (p. 42) provides a list of the COST wells drilled on the Gulf of Mexico OCS.

\section{Geology and Petroleum Poteritial of the Gulf of Mexico Region}

\section{Eastern Gulf of Mexico Planning Area}

The Eastem Gulf of Mexico (GOM) Planning Area lies offshore Alabama and Florida. Physiographically, this planning area consists of the West Florida shelf and escarpment, which constitute the Florida carbonate platform, and is composed of a thick Mesozoic-Cenozoic sequence of primarily carbonate bank deposits. The most conspicuous features the South Florida Basin, the Tampa Basin, and the Destin Salt Basin) lie beneath the West Florida Shelf and are separated by the Desoto CanyonMiddle Ground Arch and the Sarasota Arch. Seaward, the West Florida Basin is an enlongated, northwest-southeast-trending basin, which is sep arated from other basins by the Cretaceous Shelf Edge Reef trend along the Florida escarpment. The Eastern Gulf basins were formed by subsidence and cooling of transitional rust after rifting began. Early sedimentation in these basins (South Florida, Tampa, and Destin Salt) consisted generally of basal clastics followed by evaporites and carbonates. Additioral clastic sedimentation occurred during Late Jurassic breaching the Middle Ground and Desoto Canyon Arches and spreading clastic sediments as far south as the Sarasota Arch. During Early Cretaceous time, reefs developed at the shelf-slope break around the rim of the Gulf.

The South Florida Basin is approximately 60,000 square miles long, one-third of which is onshore. The basin is bounded by the Peninsula Arch to the east, the Pine Key Arch to the south, Sheffieid Arch to the west, and Sarasota Arch to the north. The sedimentary section in the basin attains a maximum thickness of 25,000 feet and is composed of cyclic limestones, dolomites, and anhydrites. Where such cycles are over 250 feet thick, hydrocarbon shows have been reported. These cycles include the Dollar Bay Formation, Sunniland Formation, and Brown Dolomite Zone of the Lehigh Acres Formation. The only production from this basin is found in the Sunniland Formation. The entire Sunniland productive trend is onshore with 14 fields discovered to date; 11 are still active. The fields are associated with patch reefs and algal mounds on the northeastern part of the basin. Production occurs between 11,320 and 11,890 feet $(3,450-3,620 \mathrm{~m})$. Original recoverable oil reserves for the Sunniland ficlds were estimated to be $142 \mathrm{MMbbl}$, of which $92 \mathrm{MMbbl}$ have been produced from 1943 to 1989. Drilling on the Sarasota and Pine Key Arches have not yielded the patch reef and algal mounds, a characteristic of the productive part of the trend. Only the margins of the offshore part of the basin have been tested, whereas the center of the basin itself is untested and is considered highly prospective. The depth of the oil window for the central portion of the South Florida Basin is thought to be between 9,500 and 15,000$)$ feet. 
Table 1-5. Estimates of undiscovered aconomically recoverable oil and gas resources in the Atlantic OCS Region as of January 1990

[Oil and BOE in billion barrels; gas in trillion cubic feet]

\begin{tabular}{|c|c|c|c|c|c|c|c|c|c|c|}
\hline \multirow[b]{2}{*}{ Planning area } & \multicolumn{3}{|c|}{ Conditlonal oll(1) } & \multicolumn{3}{|c|}{ Conditional gas } & \multirow{2}{*}{$\begin{array}{l}\text { MP } \\
\text { (2) }\end{array}$} & \multirow[b]{2}{*}{$\begin{array}{l}\text { Rlsked } \\
\text { mean } \\
\text { oll(3) }\end{array}$} & \multirow[b]{2}{*}{$\begin{array}{c}\text { Rlsked } \\
\text { mean } \\
\text { gas }\end{array}$} & \multirow[b]{2}{*}{$\begin{array}{l}\text { Rlsked } \\
\text { BOE(4) }\end{array}$} \\
\hline & $\begin{array}{l}95 \% \\
\text { case }\end{array}$ & $\begin{array}{c}\text { Mean } \\
\text { case }\end{array}$ & $\begin{array}{l}5 \% \\
\text { case }\end{array}$ & $\begin{array}{l}95 \% \\
\text { case }\end{array}$ & $\begin{array}{c}\text { Mean } \\
\text { case }\end{array}$ & $\begin{array}{l}5 \% \\
\text { case }\end{array}$ & & & & \\
\hline \multicolumn{11}{|l|}{ North Atlantlc } \\
\hline Leased and unleased & 0.05 & 0.11 & 0.27 & 1.12 & 2.54 & 6.06 & 0.39 & 0.04 & 1.00 & 0.22 \\
\hline Unleased & 0.05 & 0.11 & 0.27 & 1.12 & 2.54 & 6.06 & 0.39 & 0.04 & 1.00 & 0.22 \\
\hline Leased & 0.00 & 0.00 & 0.00 & 0.00 & 0.00 & 0.00 & 0.00 & 0.00 & 0.00 & 0.00 \\
\hline \multicolumn{11}{|l|}{ Mld-AtlantIc } \\
\hline Leased and unleased & 0.08 & 0.22 & 0.47 & 2.36 & 5.35 & 11.46 & 0.44 & 0.10 & 2.36 & 0.52 \\
\hline Unleased & 0.04 & 0.17 & 0.38 & 2.08 & 4.40 & 9.05 & 0.44 & 0.08 & 1.95 & 0.43 \\
\hline Leased & 0.02 & 0.08 & 0.22 & 0.29 & 1.61 & 4.16 & 0.32 & 0.03 & 0.51 & 0.12 \\
\hline \multicolumn{11}{|l|}{ South Atlantlc } \\
\hline Leased and unleased & 0.07 & 0.21 & 0.52 & 1.69 & 4.60 & 10.38 & 0.23 & 0.05 & 1.06 & 0.24 \\
\hline Unleased & 0.07 & 0.20 & 0.49 & 1.69 & 4.39 & 9.68 & 0.23 & 0.05 & $1.0 i$ & 0.23 \\
\hline Leased & $\star$ & 0.01 & 0.02 & 0.15 & 0.26 & 0.52 & 0.09 & $\star$ & 0.02 & $\star$ \\
\hline \multicolumn{11}{|l|}{ Stralts of Florlda } \\
\hline Leased and unleased & 0.18 & 0.34 & 0.63 & 0.24 & 0.57 & 1.47 & 0.19 & 0.06 & 0.11 & 0.08 \\
\hline Unleased & 0.18 & 0.34 & 0.63 & 0.24 & 0.57 & 1.47 & 0.19 & 0.06 & 0.11 & 0.08 \\
\hline Leased & 0.00 & 0.00 & 0.00 & 0.00 & 0.00 & 0.00 & 0.00 & 0.00 & 0.00 & 0.00 \\
\hline \multicolumn{11}{|l|}{ Total Atlantlc Reglon } \\
\hline Leased and unleased & 0.02 & 0.32 & 1.17 & 2.63 & 5.65 & 10.22 & 0.80 & 0.25 & 4.51 & 1.05 \\
\hline Unleased & 0.01 & 0.34 & 1.32 & 2.62 & 6.03 & 11.36 & 0.67 & 0.23 & 3.99 & 0.95 \\
\hline Leased & 0.01 & 0.08 & 0.29 & 0.34 & 1.47 & 3.75 & 0.36 & 0.02 & 0.52 & 0.10 \\
\hline \multicolumn{11}{|c|}{ 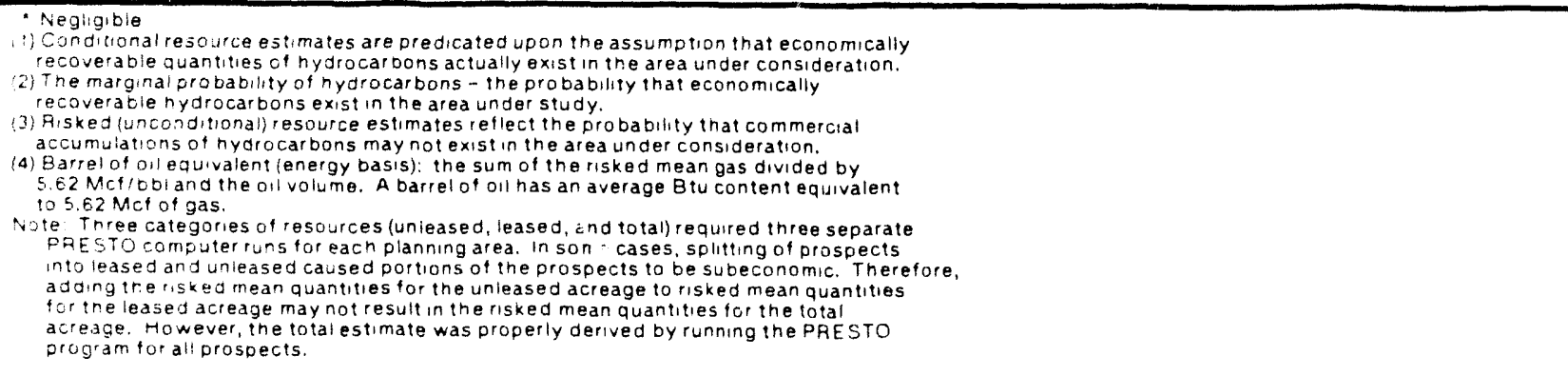 } \\
\hline
\end{tabular}

To the north, the Tampa Basin is located offishore between the Sarasota and Middle Ground-Desoto Canyon Arches and covers a 20,(K)()-square-mile ared. Wells have been drilled in the Tampa Basin; houever, no hydrexarbon shows have been recorded. Sediment thicknesses are over $18,()(K)$ feet, with the section containing more clastics than the South Florida Basin.
North of Tampa Basin is the Apalachicola and Destin Salt basins. Separating these two basins is the Florida Lineament. The Destin Anticline is a large (12- x 5()-mile [2()- $\mathrm{x} 8($ )-km]), northwest-southeasttrending structure fonmed over a salt swell within the Destin Salt Basin. Several wells have been drilled to, test the structure, and hydrocarbon discoveries have been declared on Amoxoss Destin Dome Block 111, G(18333 Well No. 1. Also, excellent reservoir rexks were encounterel in the Norphlet Fomation I Upper 


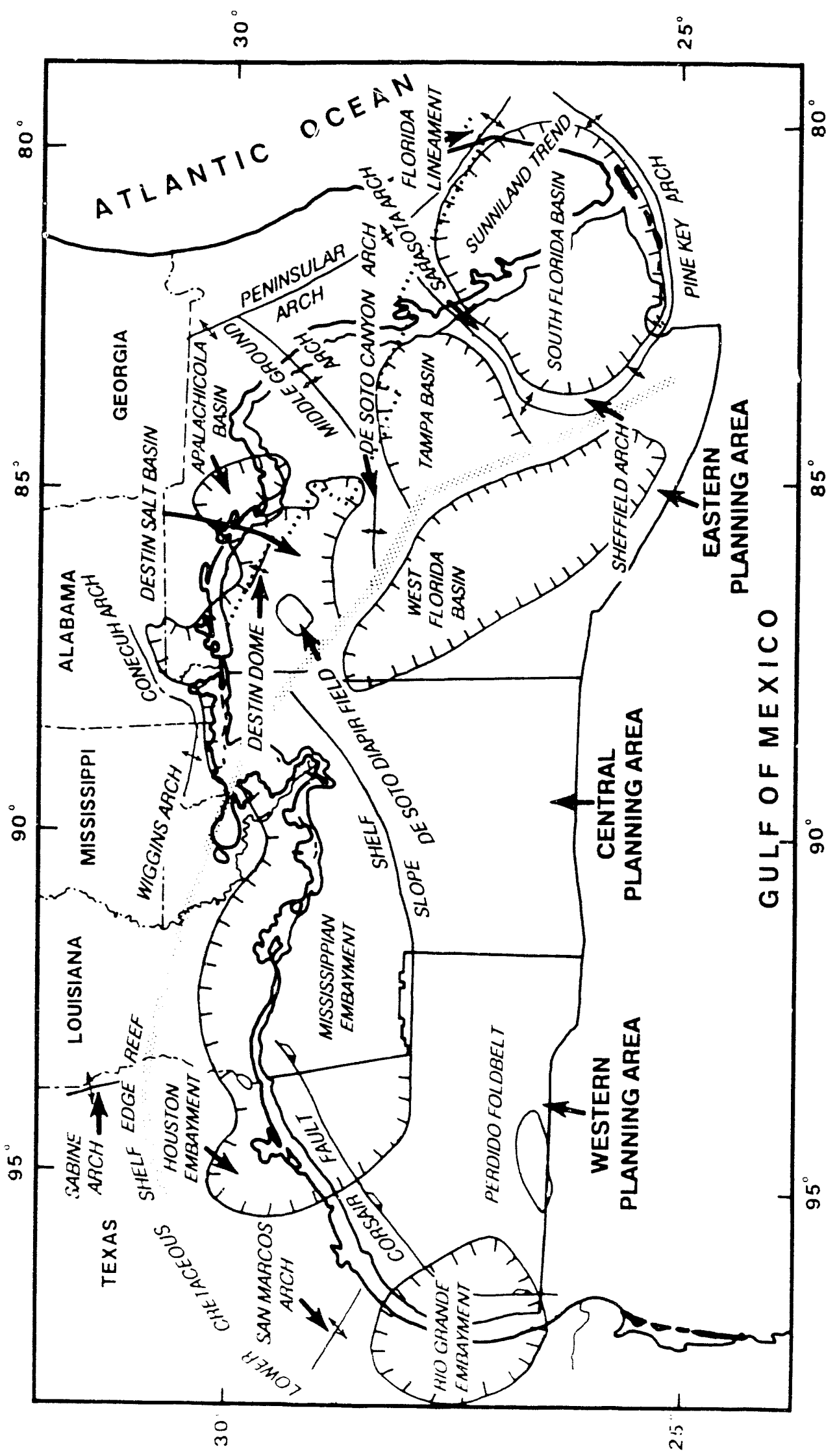

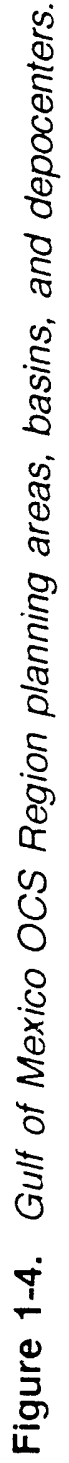




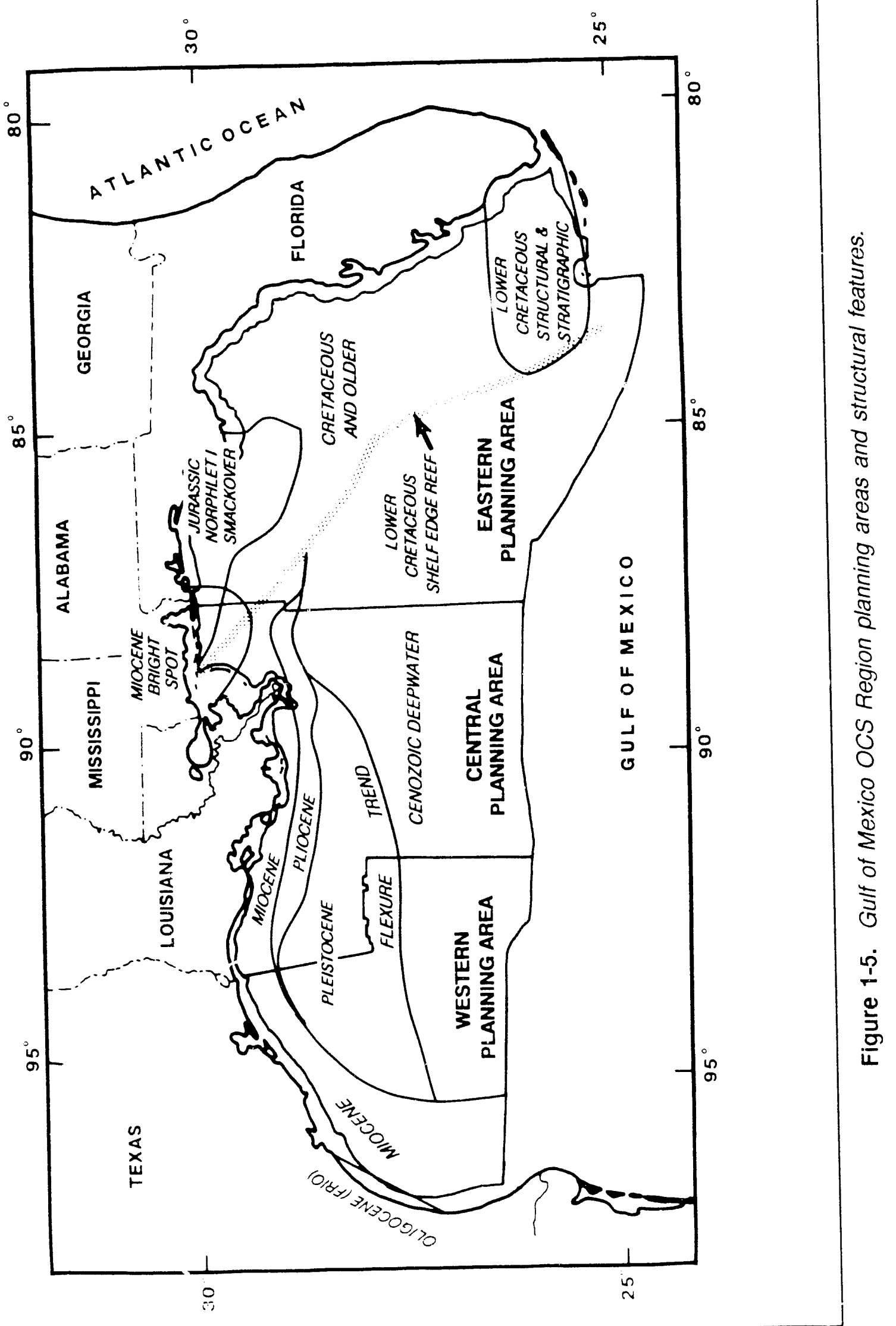


Table 1-6. COST wells drilled on the Gulf of Mexico OCS

\begin{tabular}{|c|c|c|c|c|c|c|}
\hline $\begin{array}{l}\text { Planning area/ } \\
\text { well number }\end{array}$ & $\begin{array}{r}\text { Lease/block } \\
\text { number }\end{array}$ & Operator & $\begin{array}{l}\text { Spud } \\
\text { date }\end{array}$ & $\begin{array}{c}\text { Total } \\
\text { depth }(\mathrm{ft})\end{array}$ & $\begin{array}{l}\text { Date total } \\
\text { depth reached }\end{array}$ & $\begin{array}{l}\text { USGS open-flle } \\
\text { report number }\end{array}$ \\
\hline \multicolumn{7}{|c|}{ Western Gulf of Mexico } \\
\hline $\begin{array}{l}\text { South Padre Islanid } \\
\text { Cost } 1\end{array}$ & $1076-\mathrm{L}$ & Phillips & $08 / 25 / 74$ & 15,763 & $11 / 13 / 74$ & $75-174$ \\
\hline $\begin{array}{l}\text { Mustang Island } \\
\text { Cost } 2\end{array}$ & $A-29$ & Superior & $12 / 06 / 74$ & 13,000 & $02 / 19 / 75$ & $75-259$ \\
\hline \multicolumn{7}{|l|}{ Central Gulf of Mexlco } \\
\hline $\begin{array}{l}\text { Viosca Knoll } \\
\text { Cost } 1\end{array}$ & 774 & Marathon & $08 / 27 / 89$ & 853 & $09 / 04 / 89$ & \\
\hline
\end{tabular}

Jurassic). The structure is undergoing continued exploration, and the potential for additional hydrocarbon discoveries is considered good. The Norphlet and Smackover formations of Jurassic age are potentially the most produciive sediments in the Destin Salt and Apalachicola basins.

Three depth-related productive zones within the Jurassic (Smackover/Norphlet) have been established onshore (Mississippi, Alabama, and Floridal: (1) an oil trend at $11,0(0)(15,000) \mathrm{fect}$; 12) an oil and gas-condensate trend, 16,000$19 .(1)(1$ feet; and (3) a deep natural gas trend below $19,(0)(0)$ feet.

These productive zones extended into the offisore with Mobil is Mary Ann Field deep gas discovery (Mobile Bay Block 76. Alabama State Lease 347, Well No. 1) in 1979, and into the OCS waters with MOEPSIs. Mobile Block 823. G05057. Well $\mathrm{No}$. 1, in 1983. The decp gas play was extended into the Eastern Gulf of Mexico Planning Area in 1987 and 1988, with discoveries by Amoco (Destin Dome Block 111, G(1)33x. Well Vo. 1) and Chevron (Destin Dome Block 56. G(164t)6. Well No. 1).

The source beds for these trends are lime mudene facies of the Lower Smackover Formation. Reservoir yuality rocks are present in the Smachover an the Norphlet formations.
Smackover reservoir rocks are primarily grainsupported wackestones, packstones, grainstones, and dolomites, whereas Norphlet reservoir rocks are colian sands. Prospective Cretaceous reservoir rocks are found and described as deltaic and turbidite sandstones, carbonate reefs developed on the landward side of uplifted blocks, and shell zoncs.

In early 1989, three Cenozoic discoveries in the Eastern Gulf from shallow $(1,3()()-3,()()() \mathrm{ft})$ Miocene sediments extended the known limits of the Miocene Bright Spot play into the Eastern GOM from the Central GOM Planning Area and onshore Alabama. The Miocene is represented by the Pensacola Clay, consisting of four unnamed clay members and four sund members: the basal Amos, Luce, Escambia, and uppermost Meyer Sands. Thicknesses range from 30) to 1.45 feet, with average pay thickness reaching from 15 to 20 feet.

Seaward of these shelf basins is the Lower Cretaceous shelf-edge reef trend that is productive onshore at Black Lake, Louisiana, and offshore in the Central GOM Planning Area at Muin Pass Block 254 Field. It is comidered a prospective play in the Eastern ( 30.11 . but has not been cirilled within this planning ared.

Further seaward is the Went Florida Basin in water depths greater than 1 (n) meters. The 
prospective play within this basin is considered to be an extension of the Central GOM Planning Area Lower Slope Play. Discoveries have been announced within 2 miles of the Eastem GOM Planning Area (Shell's Mississippi Canyon Block 657, G08469, Well No. 1). The prospective section is Late Cenozoic in age, and the reservoir rocks are most likely basin floor fan deposits from the ancestral Mississippi River.

Potential traps in the Eastern GOM Planning Area include (1) anticlines and faulted anticlines, (2) salt-related structural closure against normal and growth faults, and (3) a variety of stratigraphic traps. Regional growth faults parallel to the shelf edge in the Desoto Canyon area may contain traps on the downthrown side. Peripheral and radial faulting associated with salt structures may contain potential traps. Structural and stratigraphic traps in Jurassic strata that onlap basement rocks are possible targets.

\section{Central Gulf of Mexico Planning Area}

The Central GOM Planning Area encompasses (1) the continental shelf off the Louisiana coast, (2) the area east of the Mississippi Delta off the Mississippi and Alabama coasts to the eastern edge of Mobile Bay, and (3) the deeper water areas of Viosca Knoll, Mississippi Canyon, Atwater Valley, Lund, Green Canyon, and Walker Ridge. The area is largely a Mesozoic-Cenozoic basin with a series of Late Cenozoic depocenters that have shifted seaward with time. The Pleistocene depccenter is at the shelf edge. The Cenozoic province of the Central GOM Planning Area is composed of a thick sequence of clastic sediments deposited in offlapping wedger that have been deformed by the movement of salt and under-compacted shale during Cenozoic time. The Cenozoic sediment thickness could approach 47,000 feet $(14,329 \mathrm{~m})$ locally offshore southeast Louisiana. The Mesozoic province in the planning area is offshore southeast Louisiana, Mississippi, and Alabama and is composed of both clastic and carbonate rocks of Jurassic to recent age.
Structural deformation in the Gulf of Mexico since mid-Cretaceous time has been primarily in response to heavy sediment loading. Mesozoic and Cenozoic sediments have been upwarped, folded, and penetrated by diapiric structures created by the plastic flow of thick Jurassic Louann Salt deposits. Large contemporaneous growth faults are also major structural features of the Central GOM Planning Area, along with peripheral and radial faulting typically associated with diapirism.

Cenozoic clastic sediments proured into the Gulf of Mexico from the north and 'west. There are nine major producing trends in the Central GOM Planning Area: lower Miocene; middle Miocene; ujper Miocene; lower and upper Pliocene; lower, middle, and upper Pleistocene trends of the Cenozoic; and Jurassic (Norphlet) trend of the Mesozoic. Before the Miocene, the major source of sediment supply was from the west, carried by the ancestral Rio Grande and Brazos River systems. As the major supply of sediment shifted to the north and east, the Mississippi River system became the major sediment carrier; the major depocenters also shifted to the northern rim of the Gulf.

Source rocks for the Central GOM Planning Area consist primarily of organic-rich shales, which range in age from early Cenozoic through Pleistocene. However, potential Mesozoic source rocks, mostly organic rich carbonates, occur in the planning area east of the Mississippi Delta. East of the delta, reservoir rocks include sandstones, limestones, dolomite, and reef deposits of Jurassic, Cretaceous, Miocene, Pliocene, and Pleistocene ages, whereas reservoir rocks in the remainder of the planning area south of Louisiana consist primarily of sands ranging in age from Miocene through Pleistocene. The producing horizons become progressively younger in age in a seaward direction. Types of traps include anticlines and faulted anticlines formed by deep-seated salt and shale ridges, salt and shale domes and salt massifs, and structural closure against normal faults and anticlinal rollovers associated with growth faults. Stratigraphic traps include sands onlapping salt and shale domes and anticlines, and facies changes from sands to impermeable shales in updip directions and at angular unconformities. 
Older Mesozoic trends extend across southern Mississippi and Alabama and into State waters near Dauphin Island, Alabama. These trends dip and continue southeastward into the Federal Outer Continental Shelf (OCS). In the portion of the Central Gulf of Mexico Planning Area, east of the delta, prospective traps occurring in the Jurassic and Cretaceous include (1) updip sections where sands or porous carbonates pinch out or truncate updip, (2) anticlinal structures developed on the downthrown sides of growth faults over deep-seated salt domes and pillows, and (3) subtle fault closures. These trends include (1) the Jurassic Smackover, a limey mudstone and dolomitized limestone that accumulated in supratidal to subtidal environments, and (2) the Cretaceous deep Tuscaloosa (deep gas play), a geologic trend consisting of eroded clastics that may extend southeastward from onshore southern Louisiana, across the continental shelves of Louisiana and Mississippi. In addition, a current exploration trend is the Jurassic Norphlet play. Offshore, the Norphlet is a deep gas play (greater than 20,000 feet $[6,100 \mathrm{~m}]$ ) of primarily eolian sands found in a series of cast-westtrending anticlinal traps in the Mobile Bay area. Tests have run as high as 32.9-36.4 MMcfd.

The first Federal Norphlet discovery was Mobil Oil's Block 823, G05057, Well No. 1, which is being developed as a five-block field. Since then, 10 additional Norphlet field discoveries have been reported in the Region. Exxon Corporation has recently announced two development plans: one for Mobile Block 867 Unit, consisting of blocks 867,868 and 911 , and another for Mobile Block 827 Unit, consisting of blocks 827,828 , and 829 in Federal waters. Offshore Norphlet is expected to produce approximately $500 \mathrm{MMcfd}$ of gas by mid-1992 from as many as five offshore projects.

The oldest producing Cenozoic horizon in the Central GOM Planning Area is lower Miocene in age. Miocene production extends from east of the Mississippi Delta into the Western GOM Planning Area. Production is primarily from deltaic sands. A current, highly successful, exploration target is a shallow Miocene play $(1,500-5,000$ feet depth) based on seismic amplitude anomalies (bright spots) east of the Mississippi Delta resulting in numerous discoveries of gas reserves in economically payable quantities. The first offshore shallow Miocene discovery was made in 1982 by Getty on Chandeleur Block 25, followed by Mobil on Viosca Knoll Block 204. Tenneco found the shallow Miocene to be productive on Mobile Block 864 in 1983. Since then, there have been more than 35 shallow Miocene fields discovered to date in the Mobile, Viosca Knoll, and Chandeleur areas, offshore Louisiana, Mississippi, and Alabama.

Pliocene production extends from southeast of the Mississippi Delta towards the High Island area in the Western GOM Planning Area. Pliocene production also continues beneath the Pleistocene in a Pliocene-Pleistocene producing trend.

Pleistocene production extends from offshore southeast of Louisiana into the Western GOM Planning Area on the outer shelf margin and continental slope. Pliocene and Pleistocene production has already been established at several locations in water depths over 3,000 feet $(915 \mathrm{~m})$. Pleistocene production will probably exceed all other producing horizons in the Gulf of Mexico. About one-half of the shelf west of the Mississippi Delta is Pleistocene productive.

An important current exploratory play is the Pliocene-Pleistocene deep-water flexure trend. It extends along the Louisiana-Texas continental slope in deep water where salt features control the deposition of thick Pliocene-Pleistocene deltaic sediments. Most reservoirs containing oil and gas occur between 3,000 and 14,000 feet $(900-4,270 \mathrm{~m})$ in depth. These deeper water reservoirs slope more gently off of the salt than do sands on the shelf in the piercement salt dome setting. As a result, there is a larger horizontal component to these reservoirs as compared with those on the shelf where steeply dipping beds limit the areal extent. In- 
dividual tests have approached 4 Mbpd of oil and 13.1 MMcfd of gas.

\section{Western Gulf of Mexico Planning Area}

The Western Gulf of Mexico Planning Area includes the entire Texas shelf and slope, including the decp-water areas of Corpus Christi, Port Isabcl, East Breaks, Alaminos Canyon, Garden Banks, and Keathley Canyon. This area is primarily a late Cenozoic depocenter that overlies decp Paleocene and Eocene strata of carly Cenozoic age. Sedimentation in the planning area continued throughout the Cenozoic, but the sediment supply was far less than that in the Central GOM. Geophysical studies show that sediment thickness may locally approach $30,(0)(0)$ feet $(9,144 \mathrm{~m})$ in the Western GOM Planning Area.

Structurally, the Western GOM has been subjected to essentially the same tectonic forces that shaped the Central GOM. However, in contrast to the salt tectonics that controlled the deltaic depositional environment of the Central GOM, the Western GOM is characterized by an abundance of down-to-the-basin fault systems with rollover strata into the faults and linear sands deposited in offshore bar facies. The Western GOM delta systems are more tidal or wave dominated as compared with the fluvial dominated Mississippi River delta systems. Masses of undercompacted shales of Eocene or older age have flowed into younger sediments to form ridges, swells, and diapirs similar to the salt-related structures in the Central GOM. However, structurally there is less diapiric activity in the Western GOM and growth faults dominate the structural fabric. Louann Salt deposits of Middle to Late Jurassic extend beneath the Texas-Louisiana shelf and along the continental slope southerly into Mexican waters.

The hydrocarbon potential of Paleocene and older strata in the Western GOM is low because the main depositional area for these rocks lies well inland from the Western GOM. Encene deposits grade from lower axial sedi- ments onshore into bathyal sediments in the WGOM and are extremely deep and marginal. Studies indicate that Oligocene turbidites and deep-sea fan deposits may exist in the presentday shelf region.

Lower Miocene reservoir sands in the Western GOM were deposited in settings ranging from shallow water strand plain sands interfingering with marine shales to abyssal-depth basin floor fan sediments along the Texas shelf. Several delta systems existed during the carly Miocene supplying sediment along the entire Western GOM margin. Locally, the lower Miocene section may exceed 10,000 feet $(3,048$ iil).

Middle Miocene sediments were deposited in settings similar to those of lower Miocene strata, and the producing horizons, generally, become progressively younger in a seaward direction. In the Brazos area, which was downthrown to the Corsair Fault System, more than 1()$,()()()$ feet $(3,() 48 \mathrm{~m})$ of the middle Miocene section has been penetrated.

Upper Miocene strata, in general, were subjected to the same types of depositional regimes as the middle and lower Miocene strata. However, the major axis of deposition had shifted eastward into the Central GOM by late Miocene time. Upper Miocene production is scattered across the Texas shelf, but is minor and less productive than the older Miocene section because of a lesser sediment supply.

The Pliocene strata, in general, are even more limited than the upper Miocene in the Western GOM. Pliocene production occurs in the Higi Island portion of the Western GOM, but is minor and less productive than off Louisiana because of a lesser sediment supply.

The Pleistocene sequence is characterized by large quantities of sand deposited under predominantly marine conditions. Although punctuated by minor transgressions, it was dominantly a regressive period. Pleistocene production is prolific in the southern half of the High Island 
area and extends into the Galveston area of the Western GOM. Pleistocene production also extends southward into deep water as an extension of the flexure trend of the Central GOM.

Petroleum development in the Western GOM has progressed similarly with that in the Central GOM, though not as rapidly. Production extends as far south as North Padre Island where there are six fields. Exploration and development have, in general, progressed from north to southwest along the shelf and southward into deeper water.

Source rocks consist chicfly of organic-rich Cenozoic shales. Studies indicate the possibility of Oligocene reservoir rocks in decper waters. Miocene reservoirs extend the length of the continental shelf in narrow depositional bands. Although there is a perceived lack of good quality reservoir rocks in the Miocene in the southernmost part of the Texas shelf because of the narrowness of the shelf, this band widens to the northeast. There are Pleistocene reservoirs in the northern part of the Western GOM that extend to the southern part of the Galveston area and also contain considerable accumulations of gas and condensate in the High lsland area. Trapping mechanisms are the same as those in the Central GOM except that (1) traps associated with rollover into growth faults are more prevalent and (2) there is less salt diapirism. Numerous anticlinal shale ridges provide structures for traps through most of the Western GOM, but salt-related features (domestridges), extending from the Central (jO.M, are present bencath the southeast Texas shelf (High Istand) and adjacent continental slope areas of Western GOM.

Major exploration trends include the westward extension of the Pliocene-Pleistocene flexure trend into the Garden Banks East Breaks deep-water areas and the Corsair trend. The pliys in the Corsair trend involve a $10(1)$ mile $116(1)-\mathrm{km}$ ) listric growth fault system with anticlinal rollower features trending northeastsouthuest through the Galveston, Brazos, Matagrorda liand, and Mustang Island areas. The productive sands are middle Miocene in age and are deposited in a deltaic environment containing gas. Prospective objectives are as deep as $16,0(0)-18,0(0)$ fect $(4,900-5,500 \mathrm{~m})$. Tests approached up to 70 MMcfd. Another exploration trend is developing in deep-water areas exceeding 4,000 feet $(1,220 \mathrm{~m})$ in Alaminos r...yon. Through seismic surveys, several giant closures were identified that are similar to overthrusts where salt-thrust compressional structures basinward of the salt have been identificd.

\section{Resource Estimates for the Gulf of Mexico OCS Region}

Table $1-7$ (p. 47) presents the current undiscovered economically recoverable oil and gas resource estimates for Gulf of Mexico OCS planning arcas.

\section{Pacific OCS Region}

The Pacific OCS Region is divided into four planning areas for the purpose of OCS oil and gas leasing. These areas, as well as basins and depocenters, are depicted in figure 1-6 (p. 48). The region lies offshore Washington, Oregon, and California.

\section{Geology and Petroleum Potential of the Pacific OCS Region}

\section{Scittitern California Planning Area}

The Southern California Planning Area includes the offshore portions of Santa Maria Basin, Santa Barbara-Ventura Basin, Los Angeles Basin, and other banks and basins of the California Continental Borderland.

The Santa Maria Basin is part of the Central Coastal Basins Province. It is separated from the Santa Barbara Channel to the south by uplifted pre-Tertiary sedimentary rocks, which caused truncation of the Paleogene sediments 
Table 1-7. Estimates of undiscovered economically recoverable oil and gas resources in the Gulf of Mexico OCS Region as of January 1990

[Oil and BOE in billion barrels; gas in trillion cubic feet]

\begin{tabular}{|c|c|c|c|c|c|c|c|c|c|c|}
\hline \multirow[b]{2}{*}{ Plannlng area } & \multicolumn{3}{|c|}{ Condlional oll (1) } & \multicolumn{3}{|c|}{ Condltlonal gas } & \multirow{2}{*}{$\begin{array}{l}\text { MP } \\
\text { (2) }\end{array}$} & \multirow[b]{2}{*}{$\begin{array}{l}\text { Risked } \\
\text { mean } \\
\text { oll(3) }\end{array}$} & \multirow[b]{2}{*}{$\begin{array}{l}\text { Risked } \\
\text { mean } \\
\text { gas }\end{array}$} & \multirow[b]{2}{*}{$\begin{array}{l}\text { Risked } \\
\text { mean } \\
\text { BOE(4) }\end{array}$} \\
\hline & $\begin{array}{l}95 \% \\
\text { case }\end{array}$ & $\begin{array}{l}\text { Mean } \\
\text { case }\end{array}$ & $\begin{array}{l}5 \% \\
\text { case }\end{array}$ & $\begin{array}{l}95 \% \\
\text { case }\end{array}$ & $\begin{array}{l}\text { Mean } \\
\text { case }\end{array}$ & $\begin{array}{l}5 \% \\
\text { case }\end{array}$ & & & & \\
\hline \multicolumn{11}{|l|}{ Eastern Gulf of Mexico } \\
\hline Leased and unleased & 0.44 & 0.95 & 1.72 & 1.27 & 1.68 & 1.84 & 1.00 & 0.95 & 1.68 & 1.25 \\
\hline Unleased & 0.31 & 0.80 & 1.54 & 0.85 & 1.11 & 1.35 & 1.00 & 0.80 & 1.11 & 1.00 \\
\hline Leased & 0.03 & 0.15 & 0.35 & 0.23 & 0.56 & 0.81 & 1.00 & 0.15 & 0.56 & 0.25 \\
\hline \multicolumn{11}{|l|}{ Central Gulf of Mexico } \\
\hline Leased and unleased & 1.63 & 3.82 & 6.70 & 17.61 & 37.66 & 63.40 & 1.00 & 3.82 & 37.66 & 10.52 \\
\hline Unleased & 0.30 & 1.87 & 4.05 & 3.34 & 18.36 & 38.57 & 1.00 & 1.87 & 18.36 & 5.14 \\
\hline Leased & 0.78 & 1.94 & 3.29 & 7.99 & 19.29 & 32.29 & 1.00 & 1.94 & 19.29 & 5.37 \\
\hline \multicolumn{11}{|l|}{ Western Gulf of Mexico } \\
\hline Leased and unleased & 0.33 & 1.58 & 3.41 & 7.26 & 25.40 & 51.31 & 1.00 & 1.58 & 25.40 & 6.10 \\
\hline Unleased & 0.09 & 1.22 & 3.13 & 1.73 & 17.95 & 44.98 & 1.00 & 1.22 & 17.91 & 4.41 \\
\hline Leased & 0.09 & 0.35 & 0.77 & 2.17 & 7.53 & 15.90 & 1.00 & 0.35 & 7.53 & 1.69 \\
\hline \multicolumn{11}{|c|}{ Total Gulf of Mexlco Reglon } \\
\hline Leased and unleased & 1.24 & 6.34 & 17.16 & 27.90 & 64.74 & 122.68 & 1.00 & 6.34 & 64.74 & 17.86 \\
\hline Unleased & 0.49 & 3.89 & 11.99 & 10.88 & 37.38 & 86.38 & 1.00 & 3.89 & 37.38 & 10.54 \\
\hline Leased & 0.28 & 2.44 & 7.71 & 10.98 & 27.35 & 53.99 & 1.00 & 2.44 & 27.35 & 7.31 \\
\hline \multicolumn{11}{|c|}{$\begin{array}{l}\text { (1) Conditional resource estimates are predicated upon the assumption that economically } \\
\text { recoverable quantities of hydrocarbons actually exist in the area under consideration. }\end{array}$} \\
\hline \multicolumn{11}{|c|}{$\begin{array}{l}\text { (2) The marginal probability of hydrocarbons. The probability that economically } \\
\text { recoverable hydrocarbons exist in the area under study. }\end{array}$} \\
\hline \multicolumn{11}{|c|}{$\begin{array}{l}\text { (3) Risked (unconditional) resource estimates reflect the probability that commercial } \\
\text { accumulations of hydrocarbons may not exist in the area under consideration. }\end{array}$} \\
\hline \multicolumn{11}{|c|}{$\begin{array}{l}\text { (4) Barrel of oil equivalent (energy basis): the sum of the risked mean gas divided by } \\
5.62 \mathrm{Mcf} / \mathrm{b} \text { bland the oll volume. A barrel of oll has an average Btu content equivalent } \\
\text { to } 5.62 \mathrm{Mcf} \text { of gas. }\end{array}$} \\
\hline \multicolumn{11}{|c|}{$\begin{array}{l}\text { Note: Three categories of resources (unleased, leased, and total) required three separate } \\
\text { PRESTO computer runs for each planning area. In some cases, splitting of prospects } \\
\text { into leased and unleased caused portions of the prospects to be subeconomic. Therefore, } \\
\text { adding the risked mean quantities for the unleased acreage to risked mean quantities } \\
\text { for the leased acreage may not result in the risked mean quantities for the total } \\
\text { acreage. However, the total estimate was properly derived by running the PRESTO } \\
\text { program for all prospects. }\end{array}$} \\
\hline
\end{tabular}

of the westernmost Santa Barbara Channel. The Santa Barbara Channel is part of the Transverse Range province. South of the Transverse Ranges lies the California Continental Borderland province. It is informally divided into the "Inner Banks and Basins" and the "Outer Banks and Basins." The boundary is arbitrarily chosen at the Santa Cruz--Catalina Ridge.

In the oftshore Santa Maria Basin, middle and late Neogene sediments overlie Cretaceous and older sediments and metamorphic rocks.
Rocks of Paleogene age are largely offshore. The few reported occurrences may represent erosional remnants or faulted slivers. The maximum thickness of Neogene sediments exceeds $10,000)$ feet $(3,000 \mathrm{~m})$. Structural trends are generally northwest-southeast.

Sedimentary rocks in the Santa Barbara Channel include a thick section of pre-Neogene marine and nommarine clastic rocks overlain by a sequence of Neogene sandstones, shales, volcanics, and tine-grained silicenus rexks. Neogene 


\section{EXPLANATION}

\section{BASINS}

1 Santa Cruz Basin

2 San Nicolas Basin

3. East Cortes Basin

4 San Clemente Basin

5. San Diego Trough

6 Capistrano Basin

7 Catalina Basin

8 Los Angeles Basin

9 Santa Monica Basin

10 Ventura Basin

11 Santa Barbara Basin

12 Santa Maria Basin

13 Sur Basin

14 Ano Nuevo Basin

15 La Honda Basin

16 Bodega Basin

17 Point Area Basin

18 Eei River Basin

19 Santa Lucia Basin

\section{\#EPOCENTERS}

A Cape Flattery Basin

B Willapa Basin

C Astoria Basin

D Newport Basin

E Coos Bay Basin

\section{STRUCTURAL FEATURE}

Alluvial Fan

- Santa Cruz/Catalina Ridge

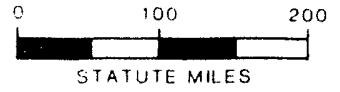

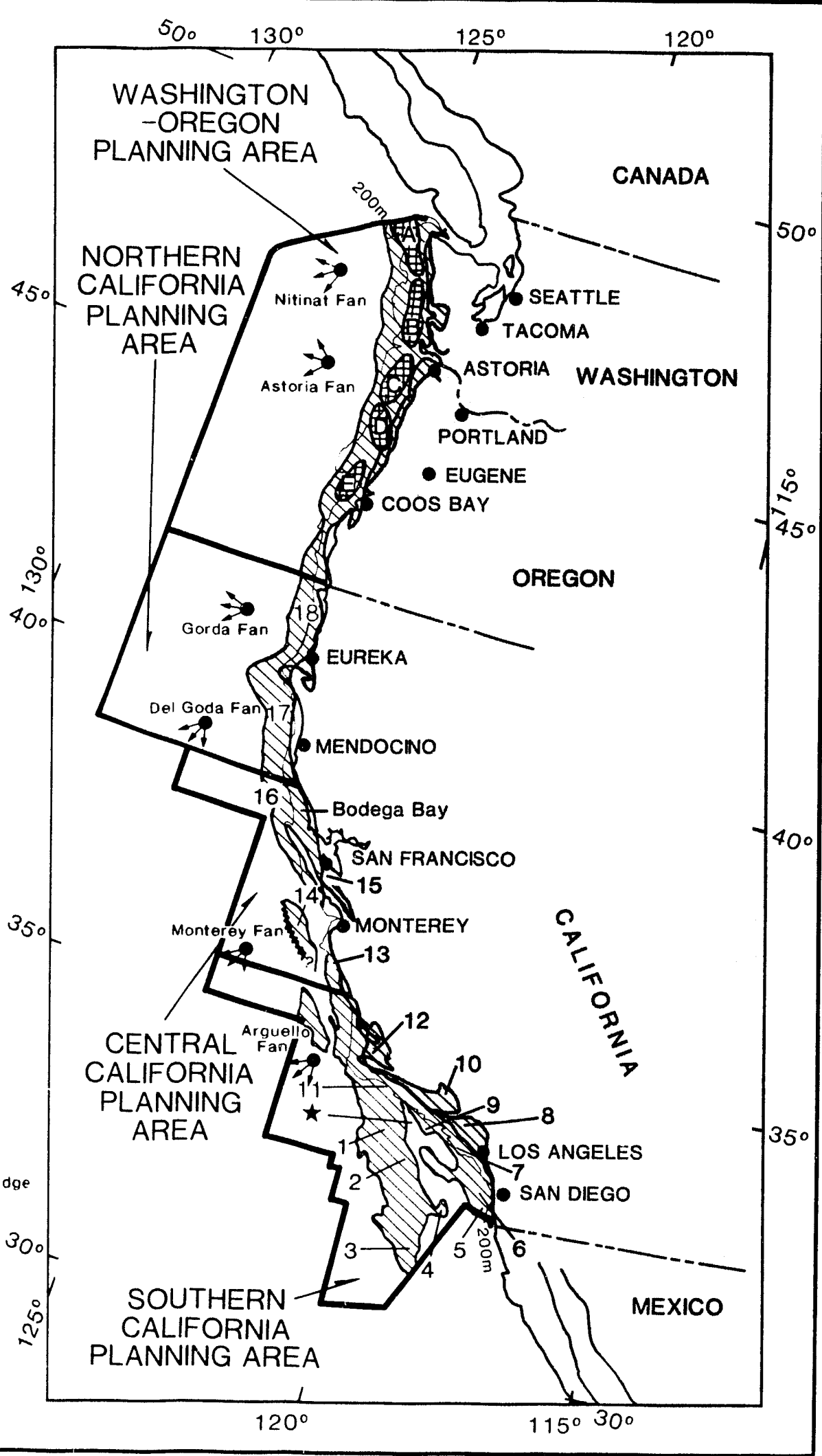

Figure 1-6. Pacific OCS Region planning areas, basins, and depocenters. 
sandstones and, to a lesser extent, shales thicken toward the northeast. In this area, sodiment thickness exceeds $20,000)$ feet $(6,000 \mathrm{~m})$. Stuctural trends are generally east-west.

The stratigraphic sequences throughout the Borderland area show remarkable uniformity, although individual sequences are missing in some places. Where complete, or nearly complete, stratigraphic sequences are preserved, they constitute evidence of common depositional environments, similar lithologies, and equivalent ages. This is especially true of the Neogene rocks. Less is known about the distribution of Paleogene rocks; however, Paleogene sequences observed in the Outer Banks are similar to those in the Santa Barbara Channel. It is not uncommon for the Neogene section to have been severely eroded, or not deposited, on the basin flanks and uplifted banks. Regionwide unconformities are seen in the upper Cretaceous and Oligo-Miocene sequences, and to a lesser degree, in the MioPliocene sedimentary rocks.

Two COST wells have been drilled, in 1975 and 1978. (Sec table 1-8 on p.50 for a detailed listing of the COST wells drilled on the Pacific OCS.) The first corehole drilled in what is now recognized as Federal waters was spudded in 1955 near San Pedro Bay. Other coreholes were drilled in the Santa Barbara Channel as early as 1956 under California State permits. About 35 coreholes were drilled in the San Pedro Bay, about 15 in the Santa Monico Bay area, one off the San Clemente coast, and over 100 in the Santa Barbara Channel area. In 1964, the first federally permitted exploratory well within the Southern California Planning Area was drilled off of Oceano in the Santa Maria Basin.

The State of California recognizes 16 fields (2 abandoned) within the onshore and State waters portion of the Santa Maria Basin. The Federal Government identifies 14 fields within the Federal Offshore Santa Maria Basin capable of production (one of which is presently producing oil).
Twenty fields capable of production have been discovered in the Federal waters of the Santa Barbara Channel area since drilling began there in 1967. Some of the discoveries may not be economically viable, and therefore may never be produced. Within the State waters and onshore portions of the Santa Barabara-Ventura Basin, over 60 fields have been discovered (including the supergiant Ventura Avenue trend).

Two fields have been discovered in Federal offshore, extension of the prolific Los Angeles Basin in the San Pedro Bay area. These fields are currently being produced from four platforms. In close proximity to Federal acreage are the supergiant Wilmington trend and the giant fields of the Newport-Inglewood fault trend. The Newport-Inglewood trend extends into untested Federal blocks of the Inner Basins area to the south.

Nine additional exploratory wells and one COST well have been drilled since 1975 on the Outer Banks. These wells penetrated a very thin Neogene section. The deep-water basins have never been tested.

Most fields in southern California are faulted anticlinal traps. The primary reservoirs in the planning area can be grouped into four broad categories: (1) Pliocene sandstones; (2) middle Miocene fractured siliceous shales; (3) lower Miocene sandstones; (4) Paleogene sandstones.

The Pliocene sandstones are composed primarily of stacked turbidite sands of the Repetto and Pico formations. In the offshore areas these units can approach a total of 10,000 fect $(3,000 \mathrm{~m})$ in thickness. The Repetto Formation is productive in the offshore Beta Field.

Miocene-age shale and sandstones are ubiquitous in the Southern California Planning Area. In the Santa BarbaraVentura Basin, the middle Miocene Monterey Formation and, to a lesser degree, the late Miocene Sisquoc Formation are composed of calcareous and siliceous shales and siltstones. Fractured reservoirs have 
Table 1-8. COST wells drilled on the Pacific OCS

\begin{tabular}{lllllll}
\hline $\begin{array}{l}\text { Planning area } \\
\text { well number }\end{array}$ & $\begin{array}{c}\text { Leaseblock } \\
\text { number }\end{array}$ & Operator & $\begin{array}{c}\text { Spud } \\
\text { date }\end{array}$ & $\begin{array}{c}\text { Total } \\
\text { depth (t) }\end{array}$ & $\begin{array}{c}\text { Date total } \\
\text { depth reached }\end{array}$ & $\begin{array}{c}\text { Report } \\
\text { number }\end{array}$ \\
\hline OCS-CAL $75-70$ & $\begin{array}{l}\text { N1 10-6 } \\
\text { Block } 463\end{array}$ & $\begin{array}{l}\text { Exploration } \\
\text { Services }\end{array}$ & $08 / 23 / 75$ & 10,920 & $12 / 02 / 75$ & OCS-0237 \\
No. 1 & $\begin{array}{l}\text { N1 } 11-10 \\
\text { Block } 553\end{array}$ & $\begin{array}{l}\text { Exploration } \\
\text { Services }\end{array}$ & $10 / 07 / 78$ & 10,571 & $12 / 18 / 78$ & 0 OCS-0222 \\
$\begin{array}{l}\text { OCS-CAL } 78-164 \\
\text { No. } 1\end{array}$ & & & & & \\
\hline
\end{tabular}

developed in these brittle formations, particularly in the cherty sections, due to tectonic deformation. Occasional coarse clastic units, such as the Santa Margarita Sand, provide additional reservoir potential locally.

In the Los Angeles Basin area, the Modelo and Puente formations are coeval with the Monterey and Sisquoc formations. Important productive sandstone units and the sand-rich zones of the Puente Formation are known to extend offishore.

Important Paleogene coarse clastic reservoirs include the nonmarine Oligocene Sespe Formation, the Eocene to Oligocene Gaviota Formation, the late Eocene Sacate Formation, and the early Eocene Matilija Formation. Some of these sandy sections have proven productive in the Federal offshore, and all have productive analogs in the State off shore of the Santa Barbara Channel area. Only very minor production has been obtained from Cretaceous-aged rocks in southern California, although it is believed sandstones of the late Cretaceous Jalama Formation may be potential reservoirs.

The Pico formation consists of turbidite sands in the Ventura Basin and shallow-water sands in the Los Angeles Basin. The Repetto Formation is composed of decp-water sandstones interbedded with abundant siltstones and mudstomes. The Santa Margarita consists of marine shelf and slope sands that interfinger with silty to diatomaceous shales of the Sisquoc Formation. Miocene sandstones, such as the Vaqueros Formation, a fine- to coarsegrained basal transgressive sandstone, and the fractured fine-grained siliceous and calcareous reservoirs of the Monterey Formation are the primary targets in most of the southern California Continental Borderland and in the southern and western Santa Barbara Channel. In the Santa Maria Basin, the Monterey is the primary target. The Monterey Formation is composed of highly organic beds of siliceous shale, interbedded with calcareous shale, chert, and phosphatic dolomite.

Paleogene sandstone reservoirs are additional targets in the Channel, in the southern portion of the Inner Basins, and in the Outer Basins. Miocene shales, such as the diatomaceous, deep-marine Sisquoc Formation and especially the highly organic shales of the Monterey Formation, are considered to be the major source rocks of petroleum in southern California Pliocene and late Paleogene shales may also be source rocks. High-gravity oil in the Sespe and Vaqueros formations is probably sourced from Eocene-aged shales.

\section{Central California Planning Area}

The Central California Planning Area includes the Bodega Basin, the offshrure extension of the La Honda Basin, the Año Nuevo Basin, and the Sur Basin. The Central California Planning 
Area is the offshore portion of the Central Coastal Basins Provinces, and structural folds and faults trend northwest-southeast approximately parallel to the basin trends.

The Año Nuevo Basin, named for its only coastal exposure at Point Año Nuevo, near Santa Cruz, trends northwest from the Monterey Bay area. It is on trend with and may represent an offshore extension of the Salinas Basin. Two wells were drilled in this basin in the 1960's. Total sediment thickness approaches 12,000 feet $(3,600 \mathrm{~km})$. The La Honda Basin was originally described onshore as a structural, fault-bounded basin with Paleogene to recent sedimentation. Uniquely for this area, the remnants of the Paleogene forearc basin were preserved. It is believed that the older rocks trend of shore to the northwest and are present west of the San Gregorio fault in the Federal OCS. The offshore La Honda Basin area has never been drilled. Sediment thickness may exceed 20,000 feet $(6,000 \mathrm{~m})$ in parts of the basin.

The Bodega Basin lies on trend with the La Honda Basin. The Bodega Basin has a thicker Neogene section and a thinner Paleogene section than the La Honda Basin. Some seismic data suggest that a slight basement warp may exist between the basins. At its thickest, the sedimentary section in the Bodega Basin exceeds 15.000 feet $(4,500 \mathrm{~m})$. Sedimentary rocks of the basin are exposed in the Point Reyes and Bolinas Peninsula area and were drilled offshore in the 1960 's.

Distribution of Paleogene and older sediments in the basins varies considerably. In the Sur (northern Santa Maria) and Año Nuevo basins, Paleogene strata appear to be absent. Late Cretaceous sediments are overlain by Miocene sediments and volcanics in the Año Nuevo Basin. The onshore La Honda and Bodega basins, however, contain Paleogene sediments, although late Paleogene sediments in the Bodega Basin are absent because of erosion.

In contrast to the Paleogene, Neogene sediments are widely distributed over the basins, and fine-grained calcareous and siliceous rocks of the Monterey Formation are present in all the basins located within the planning area. In the Sur Basin, the Monterey Formation apparently rusts on basement rocks, but in the Año Nuevo Basin, a thick section of Monterey Formation rocks overlies early Neogene sediments and volcanics. Early to late Neogene sediments and volcanics are present throughout the $\mathrm{La}$ Honda and Bodega basins, although late Miocene erosion remoyed much of the Monterey Formation in some portions of the basins. In the basins, rocks of the Monterey Formation are overlain by varying thicknesses of late Neogene mudstone, shale, and minor amounts of sandstone.

Following the issuance of leases resulting from the 1963 OCS lease sale, 10 wells were drilled in the Bodega Basin, beginning in 1963, and 2 wells were drilled in the Año Nuevo Basin, beginning in 1967. In both Año Nuev? Basin wells, drill cuttings throughout the nearly 3,000 feet $(900 \mathrm{~m})$ of Monterey Formation were coated with free tarry oil, but no drillstem tests were run. Oil shows, including stains, fluorescence, and oil bleeding, were encountered in six of the Bodega Basin wells, one of which (P-027 No. 1) was tested. How ever, only gas-cut drilling mud and water were recovered.

Some of the earliest oil and gas production in California (circa 1880) came from onshore fields adjoining the Central California Planning Area. The size and number of the fields discovered, however, proved to be small, and their ultimate production will probably be less than $10 \mathrm{MMbbl}$ of oil $\left(16^{\circ}-45^{\circ}\right.$ API gravity) and $10 \mathrm{Bcf}$ of gas. Production was derived from reservoirs of Eocene through Pleistocene age.

Whereas the primary source and reservoir rocks in the basins within the planning area are in the Monterey Formation of middle and late Miocene age, reservoir potential exists within sandy facies of the Pliocene Purisima Formation and the late Miocene Santa Margarita Sandstone. The middle Miocene Laird and 
Lompico Sandstones (basal Monterey Formation sandstone) and early Miocene Mindego Formation (which includes the basal Vaqueros Sandstone) also provide additional reservoir potential. The prominent Eocene Butano Sandstone and sandy facies of the Oligocene San Lorenzo Formation may provide potential reservoir in the offshore La Honda Basin area, especially if they are fractured. The Paleocene and late Cretaceous sections are not generally considered to have reservoir potential.

The mudstones and shales of the Oligocene San Lorenzo Formation are considered to have fair source rock potential. They are the probable source rocks for at least one of the onshore La Honda Basin fields. The early Miocene shale members of the Mindego Formation, which are cocval to the Rincon Formation of the Santa Barbara area, are potentially source rocks. The late Miocene Santa Cruz Mudstone (the shaley equivalent of the Santa Margarita Sandstone) is also thought to have source potential. Pliocene and younger rocks of the region are probably thermally immature. These source rocks are oil prone.

\section{Northern California Planning Area}

The Northern California Planning Area includes two offshore basins: the Point Arena Basin and the Eel River Basin. Point Arena Basin is part of the Central Coastal Basins Provinces. Eel River Basin is part of the Coast Ranges Province. These provinces are separated by the San Andreas Fault onshore and the Mendocine Fracture zone offshore.

The Point Arena Basin formed during the Oligo-Miocene changes at the North American plate boundary. The basin is underlain by basement rocks that have been attributed to the granitic Salinian block, metamorphic Franciscan complex, or the basal metasedimentary Great Valley Group. Overlying the basement complex are remnants of the Paleogene forearc basin, which includes latest Cretaceous, Paleocene, and Eocene rocks of the Stewart's Point. Anchor Bay, and German Rancho formations.
The Eel River Basin is a modem-day foreare hasin. The basin is underlain by the Paleogene Coastal Belt Complex and the Eocene Yager Complex. The Coastal Belt Complex is similar in nature to, but younger than, the typical sheared Franciscan melange. It may range in age from as old as latest Cretaceous to as young as Miocene. It represents the Cenozoic accretionary prism. The Yager Complex represents slope sediments that are generally less disrupted than the Coastal Belt Complex.

Eros:on has removed younger Paleogene rocks, and the remaining sediments are overlain by a thick section of Neogene rocks whose age varies from early Miocene through Quaternary in the Point Arena Basin and MiocenePliocene(?) through Quaternary in the Eel River Basin. Neogene sediments attain a thickness of as much as 12,000 feet $(3,600 \mathrm{~m})$ in the Point Arena Basin and 11,500 feet $(3,500$ $m$ ) in the Eel River Basin.

Structural trends in the planning area are northwest-southeast to north-south, parallel to the alignment of the basin axes. Moreover, the basin axes occur subparallel to the coastline of the planning area, as is the case for most of the basins in the Pacific OCS planning areas.

Seven exploratory wells were drilled in the planning area between 1964-66, as a result of the 1963 OCS lease sale. Three wells were drilled by Shell in 1965-66 in the Point Arena Basin. One well, P-(030 No. 1, drilled on a tightly folded structure. recovered drill cuttings coated with free tarry oil. In a wireline formation test, 50 cubic centimeters of $29^{\circ}$ API gravity oil was recovered. In the other two wells, weak oil shows were noted. The P-033 No. 1 well, drilled on a broad, gentle structure, encountered shows of tarry oil and fluorescence occurring in the Point Arena Formation, a Monterey Formation equivalent consisting of thinly laminated cherts, siliceous and sandy shales, and sandstones. Porosity ranged from 18 to 34 percent and permeability from 0.4 to $145.2 \mathrm{mD}$. The P (032 No. I well, drilled about 4 miles northeast of $P(133$ No. 1, encountered 
tar on fractures and cut fluorescence in the Point Arena Formation and oil-stained shale in the Gallaway Formation, the lithologic equivalent of the lower Miocene Rincon Formation consisting primarily of shales with interbedded sands.

The primary source and reservoir rocks in the Point Arena Basin are in the Point Arena Formation of middle and late Miocene age. This formation is coeval and lithologically similar to the Monterey Formation to the south. Additional hydrocarbon source and reservoir rocks occur in the Gallaway Formation. Other polential reservoir rocks exist (1) in the Skooner Gulch Formation, a transgressive sandstone lithologically, depositionally, and stratigraphically equivalent to the lower Miocene Vaqueros Formation and (2) younger units of the Paleogene. The Paleogene sandstones generally lack porosity and permeability (due to cementation) and some potential exists for fractured Paleogene reservoirs. Oil-stained rocks, including tar sands, crop out onshore in the Point Arena Formation.

In the offishore Eel River Basin, four exploratory wells were drilled in 1964 and 1965. Thero were no hydrocarbon shows in any of the wells. Two of the wells. P-()/4 No. I and $P$-1)ly No. I, encountered the sands of the Pliocene "Wildeat Group" turbidites from which gas is proluced onshore. However. the other two wells, P. (1) : 1. encountered Franciscan basement at 897 feet $1273 \mathrm{~m}$ ) and 2.964 feet $(90.3 \mathrm{~m})$, respectively.

Gas has been produced commercially from thin Pliocene turbidite sandstone reservoirs in two fields in the onshore Eel River Basin, and minor amounts of high gravity oil have been produced from thin sandstones in Upper Crelaceous rocks near the lown of Petrolia, 10 miles $(16 \mathrm{~km})$ south of the Eel River Basin. Hydrocarbon source rocks in the siltstones of the ('retaceous to lower Paleogene Yager Formation may contribute gas to the reservoir rocks in the Pliocene Wildeat Group and the potential Miocene reservoirs in the Monterey(?) age-equivalent Bear River Beds.

The oldest rocks in the Eel River Basin are the Bear River Beds. Unconformab!y above the Bear River Beds is found the Wildcat Group. This group has been divided into five recognized formations that span from late Miocene to Pleistocene in age. The oldest unit of the Wildcat Group is the Pullen Formation. It consists of deep-marine siliceous shales overlying a prominent basal sandstone. The formation dates from late Miocene to early Pliocene. The Pliocene Eel River Formation conformably overlies the upper Pullen Formation. It is a deep-water unit that consists of sandstones and mudstones deposited in a fan environment.

The late Pliocene to early Pleistocene Rio Dell Formation represents a shoaling depositional environment. It contains both decp- and shallow-water facies, consisting of marine sandstones, siltstones, and mudstones. Sandstones in the Rio Dell Formation are the productive reservoir in the Tompkins Hill and Table Blutf gas fielk.

The Pleistocene to Holocene Scotia Bluffs and Carlotta Formation represent the transition from shallow marine to fluvial and nonmarine facies. In the oifshore Eel River area, the Quaternary section is unusually thick, due to the tremendous volume of sediments carried by the Eel River during floods.

The wells drilled offshore during the $1960 \% \mathrm{~s}$ were not sited in prospective locations. Two wells were drilled on basement highs and the others were located in flank positions. The Eel River Basin is considered to be gas prone.

\section{Washington-Oregon Planning Area}

The Washington-Oregon Planning Area includes the northernmost extension of the Eel River Basin and five depocenters located off shore of the Coos Bay, Newport, and Astoria areas of Oregon, and the Willapa and Cape Flattery areas of Wasthington. These depocenters 
are thick accumulations within an elongate depositional trough containing rocks of late Paleogene and Neogene. The statigraphic section consists of more than 23,000 feet $(7,000 \mathrm{~m})$ of sedimentary and volcanic rocks composed of Neogene silty and tuffaceous mudstones with minor sandstones, overlying early Paleogene volcanics and sediments.

Washington-Oregon stratigraphy and hydrocarbon potential are not comparable to those of southern California. The tectonic setting and sedimentation history north of the Mendocino Fracture Zone is significantly different than south of the fracture zone.

The stratigraphic section from Eocene to Pliocene can be divided into four major depositional cycles or sequences: early Paleogene (early to mid-Eocene), late Paleogene (late Eocene to Oligocene), early Neogene (early to late Miocene), and late Neogene (late Miocene to Pliocene). The depositional phase of each cycle was separated by orogeny. The continuing Plio-Quaternary Cascadian Orogeny followed the fourth cycle. The depositional environment of each of the four sequences was nonmarine in the east and marine in the west.

The Eel River Basin, a Neogene depositional basin, extends northward from Cape Mendocino in California to offshore Cape Blanco in Oregon. Upper Neogene rocks within the basin overlie deeply eroded Paleogene basement rocks. Lower Neogene rocks are missing. In the Coos Bay depocenter, north of Cape Blanco, lower Neogene rocks are also absent, but here the upper Neogene rocks uverlie a nearly complete Paleogene section. Similar stratigraphic conditions exist offshore $W$ ashington where the Paleogene and lower Neogene sections consist of a melange of Eocene, Oligocene, and Early Miocene sediments called the Hoh Rock assemblage or Hoh River Beds that are composed of bedded turbidites, sandstones, siltstones, conglomerates, and volcanics.

Throughout most of the planning area, econovinit basement is considered to be volicanic rocks of early Eocene age. Neogene rocks, equivalent in age to the Monterey, Rincon, and Vaqueros formations of southern California, but dissimilar in lithology, are well represented offshore central Oregon.

A total of 12 exploratory wells (11 original wells and 1 redrill) were drilled on leases in the planning area between 1965 and 1967. The leases were issued following the 1964 oil and gas lease sale, the only sale held in the planning area to date; all leases were relinguished by November 30, 1969. Eight wells were drilled offshore Oregon. One well tested two gas zones at 50 thousand cubic feed per day (Mcfd) and $70 \mathrm{Mcfd}$ of gas; another well encountered shows of oil and gas; and a third yielded samples which indicated the presence of high-gravity oil in upper Neogene rocks. No significant shows were noted in the remaining wells offshore Oregon.

Four exploratory wells were drilled from three sites offshore Washington. The northernmost well had no significant shows. One well in the Willapa de pocenter tested two zones with hydracarbon shows and had additional shows which were not tested. The deeper zone in this well yielded 10-20 Mcfd of gas. Samples in another well, near Grays Harbor, had fluorescence indicating medium- to high-gravity oil, possibly similar to the 38.90 API gravity oil produced in the onshore Ocean City field. No wells were drilled in the Eel River Basin in the planning area.

Onshore, the Mist gas field was discovered in 1979 in the northwest corner of Oregon. The reservoirs are in the Eocene Cowlitz Formation, which may extend offshore to the Astoria depocenter. In southwestern Washington, minor amounts of oil have been produced from Hoh Rocks of Eocene, Oligocene, and Miocene age in the abandoned Ocean City oil field.

Potential reservoir rocks may be present in upper Paleogene and Neogene sandsiones such as deep-water turbidites. Tuffaceous sediments, resulting from the prevalent volcanic activity 
in the area during much of Tertiary time, may have degraded the reservoir quality of the rocks. Decomposition of the volcanic minerals to clay may plug the pore spaces of the sediments. Geochemical studies indicate potential hydrocarbon source rocks may be present in the upper Paleogene and Neogene shales.

Potential hydrocarbon traps may occur along the flanks and orests of large, asymmetrical. elongate, doubly plunging, faulted anticlines that have been mapped throughout the planning area. Traps may also exist in closures against major faults and may be associated with onlap and crosional truncations. Elongate diapiric structures and shale "pillows" have been identified on seismic profiles. Potential stratigraphic traps may occur along the flanks of these structures. Most of these potential traps have not been drilled.

\section{Resource Estimates of the Pacific OCS Region}

Table 1-9 (p. 56) presents the current undiscovered economically recoverable oil and gas resource estimates for Pacific OCS planning areas. 
Table 1-9. Estimated undiscovered economically recoverable oil and gas resources in the Pacific OCS Region as of January 1990

[OII and BOE in billion barrels; gas in trillion cubic feet]

\begin{tabular}{|c|c|c|c|c|c|c|c|c|c|c|}
\hline \multirow[b]{2}{*}{ Planning Area } & \multicolumn{3}{|c|}{ Conditlonal oll } & \multicolumn{3}{|c|}{ Condltlonal gas } & \multirow{2}{*}{$\begin{array}{l}\text { MP } \\
\text { HC } \\
(1)^{-1}\end{array}$} & \multirow[b]{2}{*}{$\begin{array}{c}\text { Risked } \\
\text { mean } \\
\text { oll }\end{array}$} & \multirow[b]{2}{*}{$\begin{array}{c}\text { Risked } \\
\text { mean } \\
\text { gas }\end{array}$} & \multirow[b]{2}{*}{$\begin{array}{l}\text { Risked } \\
\text { BOE(2) }\end{array}$} \\
\hline & $\begin{array}{l}95 \% \\
\text { case }\end{array}$ & $\begin{array}{c}\text { Mean } \\
\text { case }\end{array}$ & $\begin{array}{l}5 \% \\
\text { case }\end{array}$ & $\begin{array}{l}95 \% \\
\text { case }\end{array}$ & $\begin{array}{l}\text { Mean } \\
\text { case }\end{array}$ & $5 \%$ & & & & \\
\hline \multicolumn{11}{|l|}{ Southern Callfornla } \\
\hline Leased and unleased & 0.61 & 1.31 & 2.23 & 1.10 & 3.01 & 6.24 & 1.00 & 1.31 & 3.01 & 1.84 \\
\hline Unleased & 0.35 & 0.97 & 1.73 & 0.62 & 2.21 & 4.81 & 1.00 & 0.97 & 2.21 & 1.36 \\
\hline Leased & 0.12 & 0.32 & 0.73 & 0.28 & 0.86 & 2.88 & 1.00 & 0.32 & 0.86 & 0.47 \\
\hline \multicolumn{11}{|l|}{ Central Callfornla } \\
\hline Leased and unleased & 0.15 & 0.50 & 0.94 & 0.31 & 0.82 & 1.40 & 0.90 & 0.45 & 0.74 & 0.58 \\
\hline Unleased & 0.15 & 0.50 & 0.94 & 0.31 & 0.82 & 1.40 & 0.90 & 0.45 & 0.74 & 0.58 \\
\hline Leased & 0.00 & 0.00 & 0.00 & 0.00 & 0.00 & 0.00 & 0.00 & 0.00 & 0.00 & 0.00 \\
\hline \multicolumn{11}{|l|}{ Northern Callfornla } \\
\hline Leased and unleased & 0.21 & 0.89 & 1.54 & 1.25 & 2.45 & 4.18 & 0.78 & 0.69 & 1.91 & 1.03 \\
\hline Unleased & 0.21 & 0.89 & 1.54 & 1.25 & 2.45 & 4.18 & 0.78 & 0.69 & 1.91 & 1.03 \\
\hline Leased & 0.00 & 0.00 & 0.00 & 0.00 & 0.00 & 0.00 & 0.00 & 0.00 & 0.00 & 0.00 \\
\hline \multicolumn{11}{|l|}{ Washlngton-Oregon } \\
\hline Leased and unleased & 0.07 & 0.19 & 0.30 & 0.80 & 1.97 & 3.11 & 0.25 & 0.05 & 0.49 & 0.14 \\
\hline Unleased & 0.07 & 0.19 & 0.30 & 0.80 & 1.97 & 3.11 & 0.25 & 0.05 & 0.49 & 0.14 \\
\hline Leased & 0.00 & 0.00 & 0.00 & 0.00 & 0.00 & 0.00 & 0.00 & 0.00 & 0.00 & 0.00 \\
\hline \multicolumn{11}{|l|}{ Total Pacific Reglon } \\
\hline Leased and unleased & 0.63 & 2.49 & 6.12 & 2.46 & 6.12 & 12.14 & 1.00 & 2.49 & 6.15 & 3.58 \\
\hline Unleased & 0.50 & 2.16 & 5.48 & 2.05 & 5.35 & 10.81 & 1.00 & 2.16 & 5.35 & 3.11 \\
\hline Leased & 0.12 & 0.32 & 0.73 & 0.28 & 0.86 & 2.88 & 1.00 & 0.32 & 0.86 & 0.47 \\
\hline \multicolumn{11}{|c|}{$\begin{array}{l}\text { (1) The marginal probability of hydrocarbons. The probablity that economically } \\
\text { recoverable hydrocarbons exist in the area under study. } \\
\text { (2) RIsked barrels of oil equivalent (BOE) in billions of BOE. } \\
\text { Note: Three categories of resources (unleased, leased, and total) required three separate } \\
\text { PRESTO computer runs for each planning area. (See U.S. Department of the Interior, } 1989 \text {. } \\
\text { "Estimates of Undiscovered Conventional Oil and Gas Resources in the United States-- } \\
\text { A Part of the Nation's Energy Endowment," } 44 \mathrm{p} \text {.) In some cases, splitting of prospects } \\
\text { into leased and unieased caused portions of the prospects to be subeconomic. Therefore, } \\
\text { adding the risked mean quantities for the unleased acreage tr risked mean quantities } \\
\text { for the leased acreage may not result in the risked mean quantities for the total } \\
\text { acreage. However, the totai estimate was properly derived by running the PRESTO } \\
\text { program for all prospects. }\end{array}$} \\
\hline
\end{tabular}




\section{OCS Oil and Gas Leasing Program}

\section{Lease Sale Process}

The Secretary of the Interior has the statutory authority and responsibility to plan for and conduct the offering of leases for OCS acreage as directed in the OCS Lands Act, as amended 143 U.S.C. 1331, et seq.). Within DOI, MMS has primary responsibility for the management of OCS mineral operations. Numerous other State and Federal agencies participate throughout the process. Figure 2-1 (p. 58) displays each of the steps involved in the prelease phase and the partics involved at each step. (This figure does not show the Coastal Zone Management Act reauthorization changes; see ch. $5, \mathrm{p}$. 157. for more information.)

\section{Five-Year OCS Oil and Gas Leasing Program}

Section is of the OCS Lands Act (OCSLA) Amendments of $197 x$ (43 L.S.C. 1344) states that the Secretury of the Interior shall prepare, periodically revise. and maintain an oil and gas leasing program to implement the policies of the OCSLA. The leaving program consists of a schedule of proposed lease sales that indicates, as precisely as pussible, the sire, timing, and lexation of leasing attivity that the Secretary determines will best meet national energy needs for the 5-year period following the shedule's approvil. Before 1978, OCS leasing programs had been issued as a discretionary act of the Secretary of the Interior. To date, three 5 Year OCS Oil and Gar Leasing Program have been approwat by the Secretary under section is of the OCSLA. as amended.

The tirs prowram was approsed in June 1980 . That pregram included if sales in 16 OCS planning areds for the period September $19 x^{\circ}$ through June lyxs. The se sales were held ung the tract chation approich. Trade selection sales were

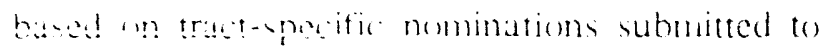

MMS from the oil and gas industry, and gencrally offered up to 2 million acres. The actual acreage offered in these sales depended on the magnitude of the nominations, hydrocarbon potential, and environmental and multiple-use considerations.

The 1980 Five-Year Program was challenged in the U.S. Court of Appeals for the District of Columbia Circuit (California v. Watt, 668 F. 21 1290 (D.C. Cir. 1981), decided October 6, 1981). In its 1981 decision, the court eritiqued certain parts of the analysis performed for that program, but allowed leasing to continue and provided guidance for the fomulation of the second program. which was then being developed.

Under the 1980) Five-Year Program, MMS held 12 lease sales and offered 12.2 million acres. As a result of these 12 lease sales, the DOI leased 792 tracts. 4.1 million acres, and received $\$ 12.2$ billion in high bonus bids.

In July 1982, the second 5-year program developed under section 18 was given final approval by the Secretary. This program scheduled 41 sales in 18 OCS planning areas between August 1982 and June 1987. A number of sales held after April 1983 used a new leasing approach known as areawide. This approach was designed to offer much more acreage than the previous tract selection method had offered. (For a detailed description of areawide leasing, see the Secretarial Issue Document for the 5-Year OCS Oil and Gas Leasing Program for mid-1987 to mid-1992, dated April 1987. This document is available from MMS s Office of Offshore Program Development \& Planning, MS 4400, $1849 \mathrm{C}$ St., NW., Washington. D.C. 2(1)24); telephone: 12(12) 2(1)8-3(1)72.) Figure 2-2 (p. 59) illustrates the impact of areawide leasing on the number of acres leased by MMS. In 1983, the first year of areawide lease sales. MMS leased over 6.5 million acres, as compared with an average of less than 2 million acres a year leased by tract selection. 


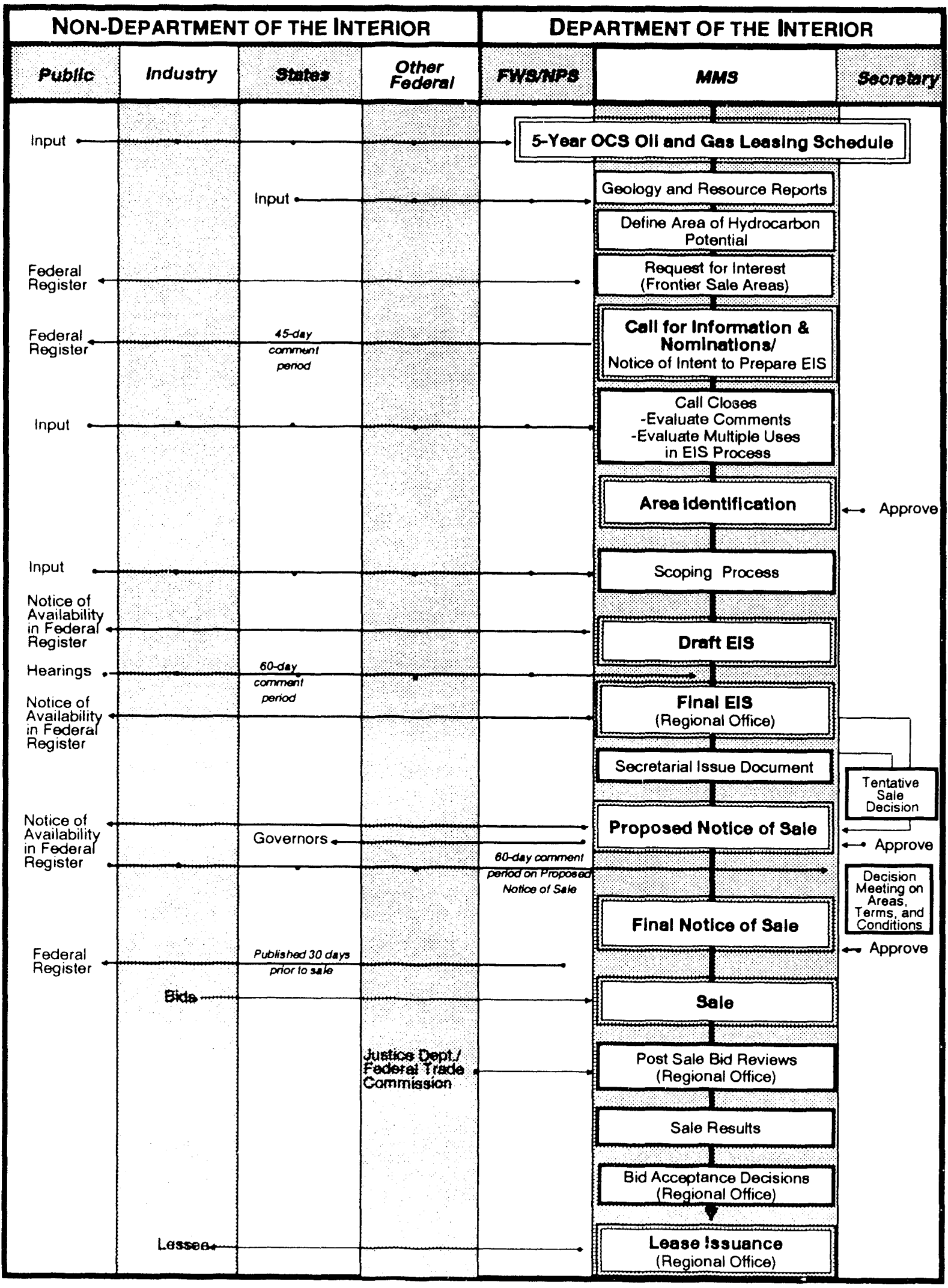

Figure 2-1. The prelease phase of the OCS oil and gas leasing process. 


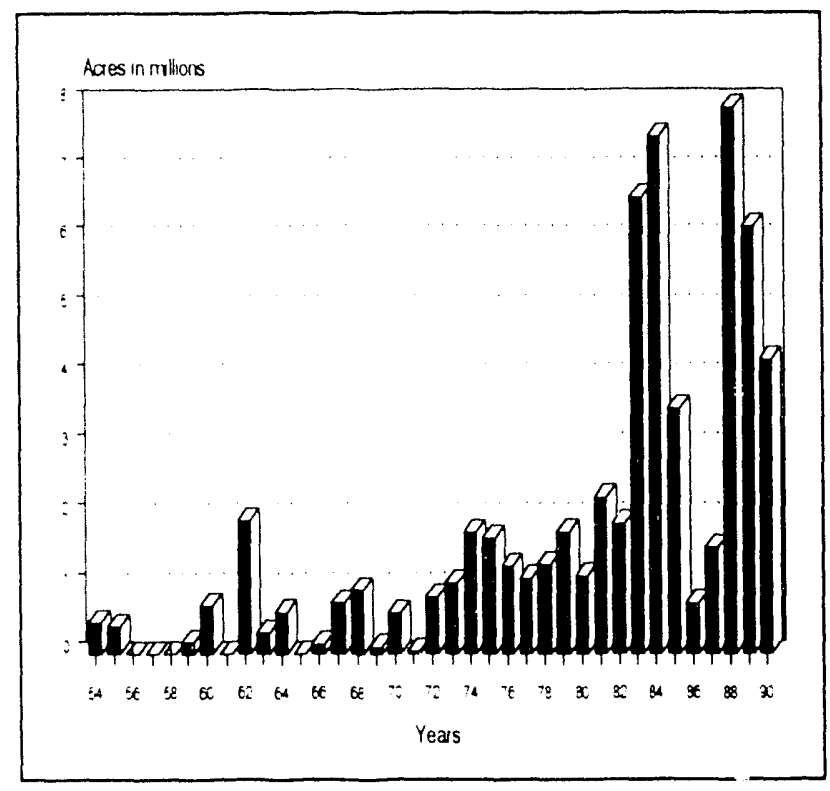

Figure 2-2. Acres leased under tract selection, areawide, and focused leasing programs, 1954 through October 1990.

The July 1982 Five-Year Program was also challenged in court (California v. Walt [II] at 611). In a July 1983 opinion, the U.S. Court of Appeals for the District of Columbia Circuit upheld the Secretary of the Interior's formulation of the 1982-87 program as having fully complied with the OCSLA and the guidance the court set forth in its 1981 opinion.

In January 1984, Secretary Clark instituted a new approach - focused leasing - which aimed at the early resolution of conflicts by the deletion of acreage with low industry interest but high environmental concern.

Under the July 1982 Five-Year Program, MMS held 23 lease sales and offered 457.4 million acres. Under this program, the DOI leased 3,973 tracts, 21 million acres, and received over $\$ 14.4$ billion in high bonus bids. (See Block Versus Tract sidebar at right.)

On July 2, 1987, the third 5-year program developed under section 18 was given final approval by the Secretary of the Interior. This program, currently in effect, scheduled 39 sales in 21 of the 26 OCS planning areas between mid-1987 and mid-1992. In addition to these 39 sales, 3 small supplemental sales of selected blocks had been scheduled; however, none of these supplemental sales have taken place. (See the Supplemental Sales sidebar on the next page for more information.)

Sales conducted under the current program use a modified leasing approach known as focusing on promising acreage to determine the size of lease sales. The DOI uses an extensive consultation and balancing process to offer acreage where OCS leasing would be environmentally sound and would potentially lead to exploration for oil and gas resources. To identify the size of the lease suie area, the DOI uses information and nominations obtained from affected States, local governments, other Federal agencies, the public, and potential bidders, as well as MMS analyses.

In addition to the modifications made to the lease sale process, two policy changes made in the past several years have effected the current

\section{Block Versus Tract}

A block is defined as a numbered area on an OCS leasing map or official protraction diagram. Blocks are portions of OCS leasing maps and official protraction diagrams that are themselves portions of OCS planning areas. Blocks vary in size, but typically are 5,000-5,760 acres (approximately $9 \mathrm{mi}^{2}$ ). Each block has a specific identifying number, area, and latitude and longitude coordinates that can be pinpointed on a leasing map or official protraction diagram.

A tract is a designation assigned for administrative and statutory purposes to a block or combination of blocks that are identified on a leasing map or official protraction diagram prepared by MMS. A tract may not exceed 5,760 acres unless it is determined that a larger area is necessary to comprise a reasonable economic production unit. 
5-year program: (1) the addition of a third lease term (sec Lease Terms sidebar below) and (2) a change in the minimum bid level.

In April 1987, the MMS used the sale-bysule reconsideration element of the 5-year program to lower the minimum bid for OCS tracts from $\$ 150$ per acre to $\$ 25$ per acre. The MMS incorporated this policy to encourage exploration and development of the OCS. The oil-price decline of 1985-86 lowered expectations of future oil and gas prices. The lower prices, combined with the large inventory of unexplored leases from previous sales, resulted in a 90 percent decline in the number of acres leased by MMS from 1984 to 1986. As was seen in figure $2-2$ on the previous page, the number of acres leased by MMS declined from 7.5 million acres in $198+$ to less than 1 million acres in 1986. Following the reduction in the minimum-bid level in 1987, along with a stabilization of oil prices. MMS leased over 2 million acres in

\section{Supplemental Sales [30 CFR 256.12]}

Effective September 8,1988 , the MMS regulations provide for the conducting of supplemental OCS lease sales (53 FR 29884). These sales are designed to give the MMS the flexibility to accelerate the leasing process, on the basis of new geological and geophysical data, where there is a need.

Supplemental sales will be limited to (1) blocks for which previously offered bids have been rejected; (2) blocks for which high bids have been forfeited, generally during the previous calendar year; and (3) blocks designated as developmental, including those susceptible to drainage. This designation indicates that a biock is located on the same geologic structure as an existing lease having a well with indicated njoccarbons.

Supplemental sales are designed to be limited in scope and to exclude blocks from the central and western Gulf of Mexico where annual OCS lease saies are conducted. The procedures for supplemental sales are similar to those for regular ocs tease saies.
1987 and a record 8.4 million acres in 1988 and 5.6 million acres in 1989. As of October 1990 , MMS has offered over $3(02$ million acres in the 11 OCS lease sales conducted under the current 5 -ycar program. Over $\$ 2.7$ billion has been received in high bonus bids for the 3,768 tracts (20.1 million acres) leased as a result of these sales.

\section{Draft Supplement to the Final Environmental Impact Statement}

Following approval of the July 1987 Five-Year Oil and Gas Leasing Program, petitioners filed suit in the U.S. Court of Appeals for the District of Columbia Circuit. Petitioners included the Natural Resources Defense Council (NRDC);

\section{Lease Terms}

Effective December 30, 1985, the Department of the Interior revised its policy on lease terms (50 FR 49041). This revised policy established a new category of leases that carry a primary lease term of 8 years. This policy revision was instituted to compensate offshore operators for the increased expense and time required for exploration of deep-water leases.

Currently, all leases let in water depths of up to $400 \mathrm{~m}(1,312 \mathrm{ft})$ carry a primary term of 5 years; leases let in water depths of from 400 to $900 \mathrm{~m}$ $(1,312-2,953 \mathrm{ft})$ carry a primary term of 8 years; and all leases let in water depths greater than 900 $\mathrm{m}(2,953 \mathrm{ft})$ carry primary terms of 10 years. Leases in areas of unusually adverse conditions may also carry a lease term of 10 years regardless of water depth.

All leases let in water depths between 400 and 900 in carry a primary term of 5 years with a right of automatic extension to 8 years upon the spudding of an exploratory well within the first 5 years. The exploratory well must be drilled to the depth, and according to other criteria, established in an approved exploration plan. 
the States of California, Florida, Massachusetts, Oregon, and Washington; and various environmental groups. They challenged the Secretary of the Interior's OCS program on a variety of grounds, including alleged violations of the National Environmental Policy Act (NEPA), section 18 of the OCSLA, and section III of Public Law 99-591, which imposed special procedures for considering leasing offshore California. The petitioners' cases were consolidated on January 29, 1988. The American Petroleum Institute, among others, intervened as respondents.

On October 30, 1988, the U.S. Court of Appeals for the District of Columbia found for DOI on 13 of the 14 grounds on which the program was challenged. The court held that in the Final Environmental Impact Statement (EIS), the Secretary failed to perform an adequate analysis of the leasing program's potential cumulative impacts on migratory species. The court remanded that matter to the Secretary for further attention and for any revision to the 5-year program that the Secretary might deem necessary as a result of this new analysis.

To respond to the court's remand and to achieve the objectives outlined by the court, the MMS prepared a supplement to the EIS. This Supplemental EIS analyzed only the cumulative impacts of OCS development on migratory specics whose migration routes traverse more than one planning area in the Alaska and Pacific Regions. The analysis was based on the court's premise that the Secretary did not consider the effects of simultaneous interregional development on migratory species.

On August 24, 1989, the MMS published a Notice of Availability of the draft EIS to the Final EIS for the Proposed 5-Year OCS Oil and Gas Leasing Program for mid-1987 to mid1992 in the Federal Register (54 FR 35256). One week later, on August 31, 1989, the MMS announced in the Federal Register (54 FR $36(061)$ that public hearings would be held the last week in September 1989 in the States of Alaska, California, and Oregon. Comments resulting from reviews of the draft of the Sup- plemental EIS and from written materials prepared as part of testimony at the public hearings were submitted to the MMS in October 1989.

Following the review of the public hearing testimony and the written comments submitted to MMS on the draft of the Supplemental EIS, a final Supplemental EIS was prepared. The Notice of Availability of the Final Supplement to the Final EIS was published in the Federal Register (55 FR 34353) on August 22, 1990.

\section{Development of the 5-year OCS Oil and Gas Leasing Program (Mid-1992 to Mid-1997)}

On July 14, 1989, the MMS published a Notice of Request for Comments on the Development of a New 5-Year OCS Oil and Gas Leasing Program in the Federal Register (54 FR 29833). As stated in section 18 of the OCSLA, the Department to the Interior is required to solicit suggestions from Federal Agencies, coastal States, and others during the preparation of a new 5-Year OCS Oil and Gas Leasing Program. The current leasing program, approved in July 1987, scheduled lease sales through June 1992. The July 14, 1989, Federal Register notice announced that MMS intends to prepare a new program for the period mid-1992 to mid-1997.

Stcps required by statute in the program development process, following the initial Notice of Request for Comments, include the development of (1) a draft proposed program, (2) a proposed program, (3) a proposed final program, and (4) a final program. An Environmental Impact Statement (EIS) will also be prepared. Initiation of the EIS process was announced in the Federal Register on July 14, 1989 (54 FR 29832). 


\section{Presidential OCS Task Force}

On February 9, 1989, in a specch to Congress, President Bush called for the "indefinite postponement of three lease sales": Sale 91 in Northern California, Sale 95 in Southern California, and Sale 116 (Part II) in the Eastern Gulf of Mexico. These sales were scheduled to occur in fiscal year 1990. The President stated "action on these three sales will await the conclusion of a special task force set up to measure the potential for environmental damage."

President Bush named the Secretary of the Interior, Manuel Lujan, as chairman of the task force. Other members of the task force are the Secretury of Energy, the Administrators of the Environmental Protection Agency (EPA), the National Oceanic \& Atmospheric Administration (NOAA), and the Director of the Office of Management and Budget. The National Academy of Sciences is providing scientific and technical review. Robert Kallman, former Director of MMS, was chosen by Secretary Lujan to be Executive Director of the task force.

The task force held its first meeting on April 14, 1989, and agreed to a set of objectives including the following: (1) review concerns over adverse environmental impacts in cach of the three areas, (2) identify and investigate environmental concerns, (3) explore leasing proposals (including no leasing), (4) review the Administration's energy goals, (5) make recommendations to the President concerning the three sales, and (6) review information regarding the oil spill in Prince William Sound and cleanup efforts that may aid in raching the above objectives. The task force held a series of nine public meetings and workshops in the areas adjacent to those sales, to obtain technical information and public opiniom on the sale proposals.

On August 11, 1989, the task force issued a notice in the Federal Register (54 FR 3315()), which outlined the staft summary of environmemal concems, presented a range of leasing options, and provided numerous specific options that may reduce potentially negative ef fects to environmental and economic resources. The notice also solicited comments on additional concerns not identified. The task force incorporated into a final report for the President the information that was received in response to the Federal Register notice and gathered at the public meetings.

The task force report was presented to the President, in January 1990. The President announced his decision on June 26, 1990. As part of these decisions, the following lease sales were canceled:

- Sales 91 and 128-Northern California;

- Sales 95 and 138-Southern California;

- Sale 116, Pt. II-Eastern Gulf of Mexico;

- Sales 96 and 134 North Atlantic;

- Sale 119-Central California; and

- Sale 132-Washington/Oregon.

In addition, the following decisions were also made:

California.-In the Southern California Planning Area, 87 tracts with high resource potential close to currently producing areas have been identified for future leasing considerations. These tracts are in the Santa Barbara Channel and the Santa Maria Basin. None of these tracts will be offered for lease before January 1, 1996, when additional oceanographic and socioeconomic studies, as recommended by the National Academy of Sciences, will have been completed. No additional leasing will occur in any other areas offshore California before the year $200(0$. The NOAA recommendation to permanently exclude oil and gas activiites in the Proposed Monterey Bay $\mathrm{Na}$ tional Marine Sanctuary has been approved. 
Air-quality controls for offshore facilities that are equivalent (1) the onshore controls will be adopted.

Florida.-No additional leasing will occur off the southern tip of Florida before the year 2f()(). The DOI will work with the State of Floricla (o) buy back existing leases in the Eastern Gulf of Mexico adjacent to the southern tip of Florida and to conduct additional oceanographic, ecological, and sociocconomic studies as recommended by the National Acadeny of Sciences, over the next 5 to 6 years.

National.-The Federal 5-year oil and gas leasing program. currently being developed by M.MS, will incorporate the President is decision. Industry and the Federal Government should immediately begin efforts to increase oil-spill response capabilities. These efforts should not be limited by spill source, but should include all pusible sourees, especially tankers. This hould begin by moving tanker routes further what from sensitive coustal resources, such as the Florida Keys and the Everglades. Environmental and resource evaluation studies will be continued in all the OCS Regions.

For further information on or for copies of any of the documents discussed above, please contat the following office:

Oflice of Program Development \& Plamning

Mneral, Management Service, MS 4400)

Ixty C Si. NW

Wahmeton, D.C. 2(1)

Telephenc: (20) 2(1k-3072

As the next 5-year OCS oil and gas leasing program in developed. working groups repreenting the various offehore interests will assist the adminintration in making policy decisions revarding the leasing and development process and will provide input on the direction of envormmental sudies. There groups consist of an oc's Avisory Bourd and its components the (x) Policy Committee, the Scientific Committe. and the Regumal Technical Working Croupst.

\section{OCS Advisory Board}

The OCS Advisory Board was established in October 1975 to provide DOI with a formal mechanism to receive comments and recommendations from coastal State officials, Federal agencies, and other public and private interests involved in OCS development. Composed of a broad-based panel of experts on the various aspects of the offshore leasing and development process, the board has three key components: the OCS Policy Committee, the Scientific Committec, and the Regional Tichnical Working Groups. Figure 2-3 (p. 64) presents an organizational outline of these component:.

\section{OCS Policy Committee}

Through the Director of MMS, the OCS Policy Committee of the OCS Advisory Board provides advice on all aspects of leasing, exploration, development, and protection of OCS resources to the Secretary of the Interior and other DOI officials. Representatives include senior officials from the offices of the coastal State governors, discretionary members from the public and private sectors appointed by the Secretary for their expertise in disciplines related to the OCS Program, and Federal members.

In 1986, the Committec began using subcommittees to examine specific issues in greater depth. There have been four subcommittees:

- Subcommittce to develop fundings and recommendations concerning policies to avert future energy crises;

- Subcommittec to develop recommendations to improve the process for developing the 5-Year OCS Oil and Gas Leasing Program;

- Subcommittee to review analysis of the Exxon Valde\% oil spill; and

- Subcommitte on oil-spill recommendations implementation.

The policy Committee generally meets twice a year. or more often when appropriate. 


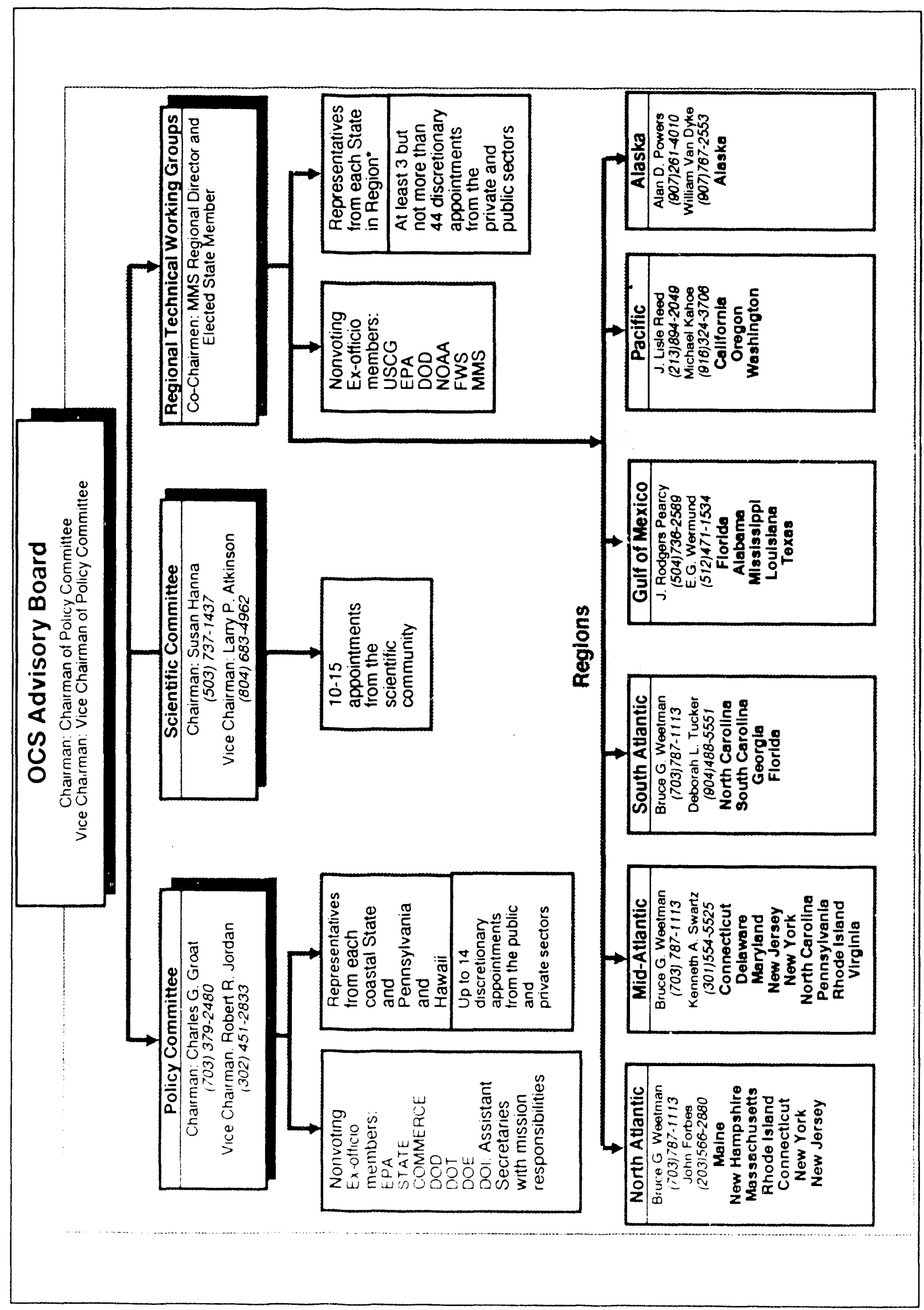

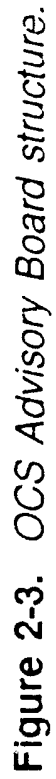




\section{OCS Scientific Committee}

The wend element of the OCS Adrinory Buard is the OCS Scientitic Committee, which is compuned of scientius from disciplines relevant to RiMS's Envirunnental Studies Pro. gram. The commintee reports directly to the Directur of MMS and advises on the appropriateness, feasibility, and scientific value of the Environmental Studies Program. (See p. 80 for more information on the Environmental Studies Program.) In addition (o) the OCS Sci. entific Committee input, each OCS region holds annual scientific information transfer meetings open to the public to review the ongoing environmental studies in the regions.

\section{Regional Technical Working Groups}

The Regional Technical Working Groups IRTWG S) are the third conponent of the OCS Advisory Board. Currently, there are six RTW'G's, one each in the Gulf of Mexico, Pacific, and Alaska OCS Regions and one in each of the three Allantic planning areas. The RTWG's review and comment on technical matters of regional concern regarding prelease and postlease activities and on environmental study requirements for each offshore leasing region. Each RTWG is composed of representatives with technical expertise from the affected States, MMS, other Federal agencies (e.g., the U.S. Fish \& Wildlife Service, EPA, NOAA, the U.S. Coast Guard, the Army Corps of Engineers, and the Department of Energy), the oil and gas industry, and other special and private interests that exist in the leasing region.

Every RTWG is co-chaired by the MMS Regional Director (or designee) and a State representative. The State representative is elected by all the State representatives on the committee; if une is not elected, then the chair is ro. cuted anment the state members. 


\section{National Overview of OCS Leasing}

Since 1954, the DOl has leased over 63 million acres in 102 lease sales and has received over $\$ 55$ billion in high bonus bids. Figure 2.4 (right) breaks these totals down by region. As seen by the figure, the Gulf of Mexico Region has received the most interest. This interest is further highlighted by the percentage of the total number of leases currently active on the OCS. Figure 2-5 (below) shows that as of October 31, 1990, the Gulf of Mexico Region held approximately 86 percent of the 7.904 existing leases on the OCS.

As discussed in the introduction, the price of crude oil has influenced the U.S. economy since the oil embargo of 1973. This influence can be seen within the OCS leasing program. Figure 2.6 (right) shows how the price of oil affected the cotal amount of high bonus bids received per year.

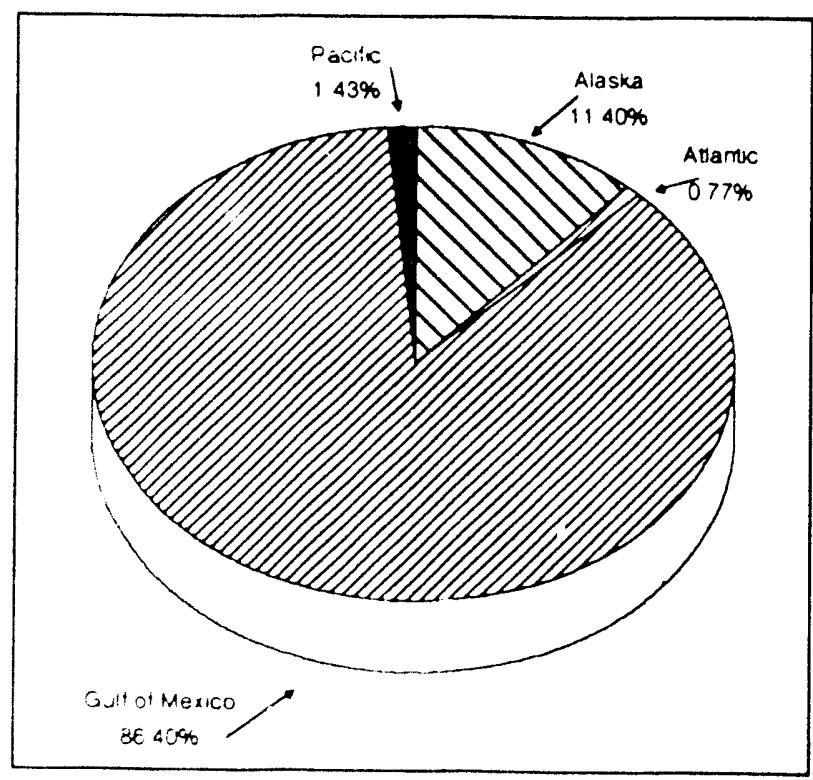

Figure 2-5. Existing leases by OCS region as of October 31, 1990.

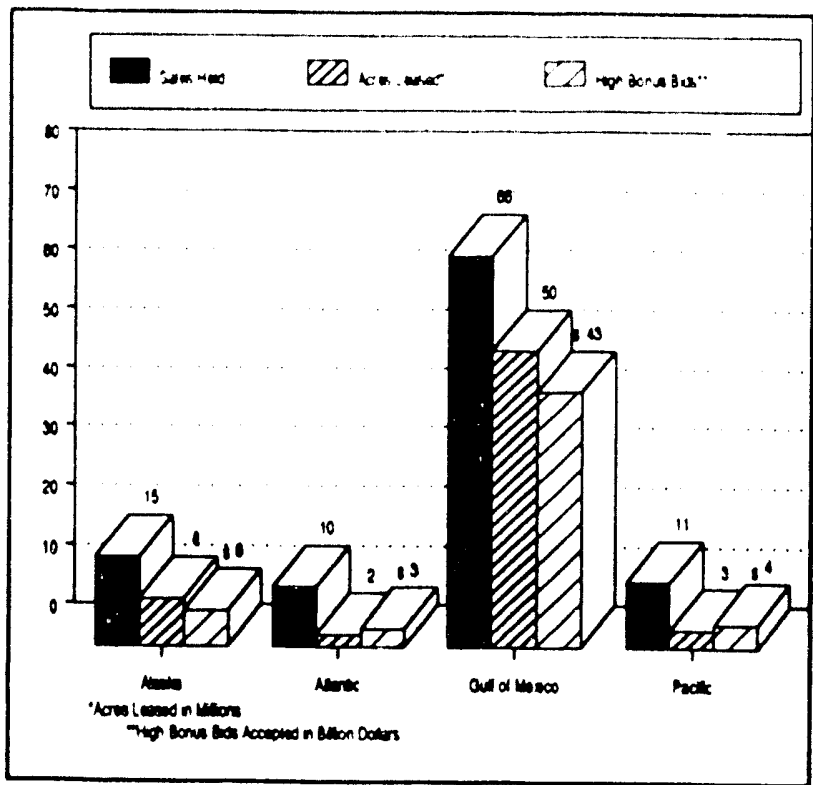

Figure 2-4. Number of sales held, acres leased, and high bonus bids accepted by OCS region, 1954-October 31, 1990.

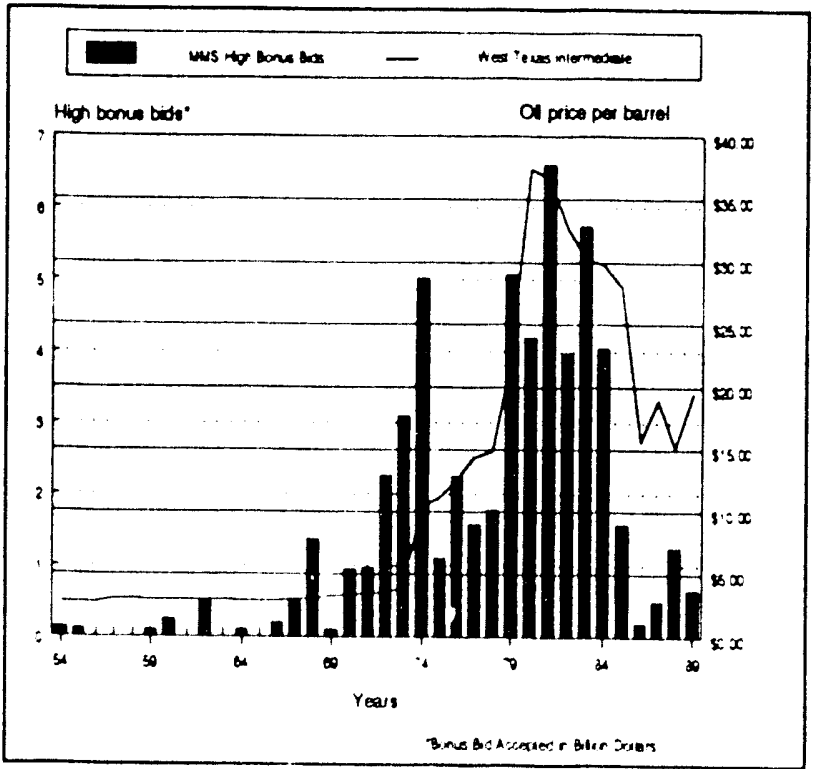

Figure 2-6. Comparison of oil price and high bonus bid accepted, 1954-89. 


\section{Alaska OCS Region}

The firs lease sale for OCS acreage offshore Alaska was held in 1976. Since that time. a twal of 15 sales hate been held. The DOI has leand 1.466 tracts 18.1 million acres) and has recised over $\$ 6 .+$ billion in high bonus bids. Mine of these sales were held under the auspices of previous 5-year OCS oil and gas leasing shedules. Of the 12 sales scheduled under the current July 1987 Final 5-Year Program, 2 have already cecurred; Lease Sale 97 (Beaufort Sea) was held on March 16, 1988, and Lease Sale llly (Chukchi Sea) was held on May 25 , $19 \times 8$

In addition to these sales, bids for one lease sale. OCS Lease Sale 92 (North Alcutian Basin), originally held January 13, 1986, were upened on October 11, 1988. MMS received 23 bid on 23 tracts and accepted over $\$ 95$ million in high bonus bids. For more information (n) thir leave sule, refer to the Alaski Ledate. September 198x-January 1990 (.M.MS 9010121 . This report is available from MMS at the addres linted in the Preface of this document. Alwo, 17 bid submitted by four oil companie, for tracts offered in February 1984 - OCS Lease Sale 8. . Navarin Basin) were returned in December 1988. The MMS returned Sil).3 million, the one-fifth bonus submitted at the lease sale plus interest, to four of the oil companies that bid at the sale. The 17 leases are involved in a boundary dispute with the Sovet (nion. During the summer of 1990), a final agrement was reached between the State Department and the Soviet Lnion regarding this di-pute. The agreement has been sent to the L.S. Senate for ratification.

An of Ocwber 31, 1990, there were 901 actide leases un ned by 32 companies. Figure $2-7$ tright bust the top 10 Alastia OCS leasehold or by percomatge of acreage held. Specific information on each of the Alarka OCS lease ale is presented in tables $2-1(p .6 x)$ and $2-2$ u. 6 .
The MMS Alaska OCS Region developed a chart that graphically depicts the stipulations that have been used for oil and gas lease sales in the Alaska OCS Region. The chant is categorized into the Gulf of Alaskal Cook Inlet Region, the Bering Sea Region, and the Arctic Region. Table 2-3 (p.7(1) presents the information provided on the chart. The wording of the stipulations can be tound in the Notice of Sile for each of the sales listed in the table. A narrative publication that will include the wording is fortheoming, and will be distributed as soon as it is available.

For further information or copies of the chart. contact the MMS at the following address and telephone number. The chart comes in two cizes: 19 $x 15$ inches and $4 \times 3$ feet.

Minerals Management Service

Alaska OCS Region

949 E. 36 th Ale., Room 110

Anchorage, Alaskid 495()$x-4302$

Telephone: $19(17) 261-4+35$

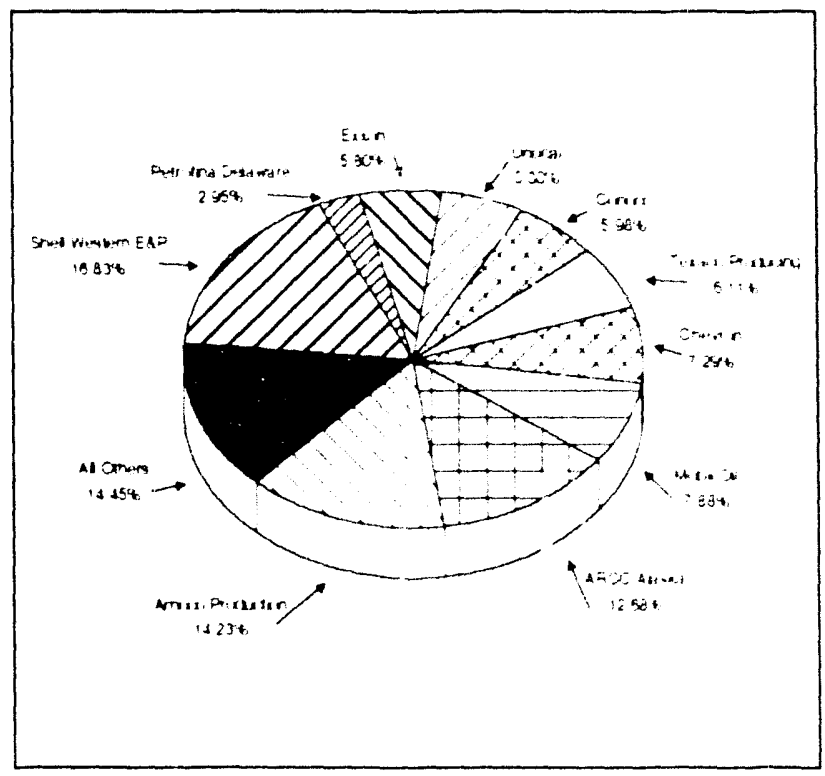

Figure 2-7. Top 10 Alaska OCS leaseholders by percentages of acreage held as of October 31, 1990. 
Table 2-1. Lease sale history of the Alaska OCS Region as of October 31,1990

\begin{tabular}{|c|c|c|c|c|c|c|c|c|c|c|}
\hline $\begin{array}{l}\text { Planning } \\
\text { Area }\end{array}$ & $\begin{array}{l}\text { Lease } \\
\text { Sale }\end{array}$ & $\begin{array}{l}\text { Date } \\
\text { Held } \\
\text { (Proposed) }\end{array}$ & $\begin{array}{l}\text { Blocks } \\
\text { Offered }\end{array}$ & $\begin{array}{l}\text { Acres } \\
\text { Offered }\end{array}$ & $\begin{array}{l}\text { Leases } \\
\text { Issued }\end{array}$ & $\begin{array}{l}\text { Acres } \\
\text { Leased }\end{array}$ & $\begin{array}{l}\text { Wells } \\
\text { Drllled }\end{array}$ & $\begin{array}{l}\text { OCS } \\
\text { Order } \\
\text { No.4 }\end{array}$ & $\begin{array}{l}\text { Existing } \\
\text { Leases }\end{array}$ & $\begin{array}{l}\text { Existing } \\
\text { Acreage }\end{array}$ \\
\hline \multicolumn{11}{|l|}{ ARCTIC } \\
\hline \multirow[t]{2}{*}{ DIAPIR FIELD } & 71 & $10 / 1=/ 82$ & 338 & $1,825,770$ & 121 & 662,860 & 7 & $2^{\star \star}$ & 71 & 398,445 \\
\hline & 87 & $08 / 22 / 84$ & 1.419 & $7,773.447$ & 227 & $1,207,714$ & 6 & $1 * \star$ & 201 & $1,074,418$ \\
\hline \multirow[t]{3}{*}{ BEAUFORT S:A } & SF & $12 / 11 / 79$ & 46 & 173.423 & 24 & 85,776 & 8 & $5 \star \star$ & 2 & 7.495 \\
\hline & 97 & $03 / 16 / 88$ & 3,344 & $18,277,805$ & 202 & $1,110,764$ & & & 202 & $1.110,912$ \\
\hline & 124 & $(04 / 91)$ & & & & & & & & \\
\hline BARFOW ARCH & 85 & CANCELED & $(03 / 09 / 84)$ & & & & & & & \\
\hline \multirow[t]{2}{*}{ CHUKCHI SEA } & 109 & $05 / 25 / 88$ & 4.694 & $25,531,122$ & 339 & $1,914,285$ & \multirow{2}{*}{\multicolumn{2}{|c|}{$4 \#$}} & 350 & $1,976,872$ \\
\hline & 126 & $(08 / 91)$ & & & & & & & & \\
\hline HOPE BASIN & 133 * & $(05 / 92)$ & Deferred & & & & & & & \\
\hline \multicolumn{11}{|l|}{ BERING SEA } \\
\hline \multirow[t]{3}{*}{ NORTON } & 57 & $0.3 / 45 / 03$ & 418 & $2,379,751$ & 59 & 335,898 & 6 & & 0 & 0 \\
\hline & 100 & CANCELED & $(04 / 07 / 86)$ & & & & & & & \\
\hline & $120 *$ & Deferred & & & & & & & & \\
\hline \multirow[t]{3}{*}{ NAVARIN } & 83 & $04 / 17 / 84$ & 5.036 & 28.048 .995 & 163 & 927,989 & 8 & & 22 & 125,253 \\
\hline & 107 & $07 / 90$ & & & & & & & & \\
\hline & $130 *$ & $(06 / 92)$ & Deferred & & & & & & & \\
\hline \multirow[t]{3}{*}{ ST. GEORGE } & 70 & $04 / 12 / 83$ & 479 & $2,688,187$ & 96 & 540,917 & 10 & & 30 & 170,798 \\
\hline & 89 & CANCELEO & $(05 / 02 / 86)$ & & & & & & & \\
\hline & $101 *$ & Deferred & & & & & & & & \\
\hline \multirow[t]{2}{*}{ NOFTH ALEUTIAN } & 92 & ENJOINED & 990 & 5.603 .472 & 23 & 121,754 & & & 23 & 121,756 \\
\hline & 117 & Deferred & & & & & & & & \\
\hline \multicolumn{11}{|l|}{ GULF OF ALASKA } \\
\hline \multirow[t]{4}{*}{ COOKINLET } & $\mathrm{Cl}$ & $10: 27 / 77$ & 135 & 768,580 & 87 & 495.307 & 10 & & 0 & 0 \\
\hline & 60 & $09 / 29 / 81$ & 153 & 858,247 & 13 & 73,157 & 3 & & 0 & 0 \\
\hline & RS2 & $08 / 05 / 82$ & 140 & 785.091 & 0 & 0 & 0 & & 0 & 0 \\
\hline & 136 & Deterred & & & & & & & & \\
\hline \multirow[t]{4}{*}{ GULF OF ALASKA } & 39 & $04 / 13 / 76$ & 189 & 1.008 .499 & $7 \widehat{0}$ & 409,058 & 11 & & & \\
\hline & 55 & $10 / 21 / 80$ & 210 & 1.195 .569 & 35 & 199,261 & 1 & & & \\
\hline & RS 1 & $06 / 30 / 81$ & 175 & 996,300 & 1 & 5.693 & & & & \\
\hline & 88 & CANCELED & $(05 / 02 / 86)$ & & & & & & & \\
\hline $\begin{array}{c}\text { [GULF OF ALASKA } \\
\text { NOOK INLET] }\end{array}$ & 114 * & Deterred & & & & & & & & \\
\hline \multirow[t]{2}{*}{ SHUMAGIN } & 86 & CANCELED & $(02 \cdot 2686)$ & & & & & & & \\
\hline & $129^{*}$ & Deterred & & & & & & & & \\
\hline MOCAK & 127 & CANCELED & $(0+27 / 87)$ & & & & & & & \\
\hline \multirow{3}{*}{$\begin{array}{l}\text { SUPPLEMENTAL } \\
\text { SALES*** }\end{array}$} & SU-1 & 109831 & & & & & & & & \\
\hline & Su-2 & $109.90)$ & & & & & & & & \\
\hline & $\mathrm{Si}-3$ & $10991)$ & & & & & & & & \\
\hline \multicolumn{2}{|c|}{ TOTAL } & & 17.760 & 87914859 & 1.456 & 8.090 .433 & 74 & $8^{\star \star}$ & 901 & 4985949 \\
\hline \multirow{2}{*}{\multicolumn{11}{|c|}{ 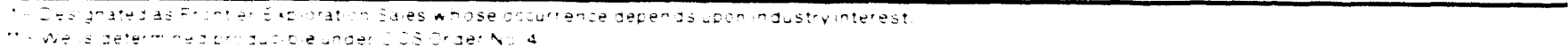 }} \\
\hline & & & 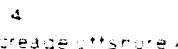 & & & & & & & \\
\hline \multirow{2}{*}{\multicolumn{11}{|c|}{ 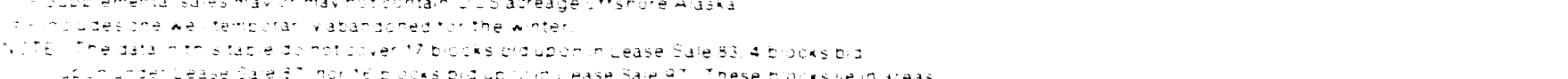 }} \\
\hline & & & & & & & & & & \\
\hline 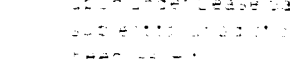 & ases-ats & a $\cdots \cdots+$ gn & 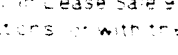 & $=5: 3$ & & & & & & \\
\hline
\end{tabular}


Table 2-2. Dates of and Federal Register notices for signiikunt prelease steps for proposed Alaska OCS lease sales from January 1987 througn October 31, 1990

\begin{tabular}{|c|c|c|c|c|c|c|c|c|}
\hline \multirow{2}{*}{$\begin{array}{l}\text { Lease Sale } \\
\text { number/area }\end{array}$} & \multirow{2}{*}{$\begin{array}{l}\text { Pre-Step } \\
\text { Request for } \\
\text { Interest }\end{array}$} & \multicolumn{7}{|c|}{ Prelease steps $(1)$} \\
\hline & & $\bar{C}$ & $\bar{A}$ & $\bar{E}$ & $F$ & $\bar{P}$ & $N$ & $\mathrm{~S}$ \\
\hline $\begin{array}{l}\text { SU-1, } \\
\text { Supplemental Sales \# }\end{array}$ & & & & & & & & $\begin{array}{c}\text { Proposed } \\
09 / 89+ \\
\text { Deferred }\end{array}$ \\
\hline $\begin{array}{l}107, \\
\text { Navarin Basin }\end{array}$ & & $\begin{array}{c}04 / 24 / 84 \\
49 \mathrm{FR} 17686 \\
04 / 28 / 86^{\star \star \star} \\
51 \text { FR } 15851\end{array}$ & $07 / 27 / 84$ & $\begin{array}{c}05 / 23 / 90 \\
55 \text { FR } 21262\end{array}$ & $12 / 07 / 90$ & $01 / 30 / 91$ & $06 / 07 / 91$ & $\begin{array}{l}\text { Proposed } \\
07 / 91\end{array}$ \\
\hline $\begin{array}{l}\text { 101. } \\
\text { St. George Basin }\end{array}$ & $\begin{array}{c}06 / 19 / 87 \\
52 \text { FR } 23418\end{array}$ & $\begin{array}{c}10 / 08 / 87 \\
52 \text { FR } 37756\end{array}$ & $02 / 02 / 88$ & & & & & $\begin{array}{l}\text { Proposed } \\
\text { Deferred }\end{array}$ \\
\hline $\begin{array}{l}114, \\
\text { Gulf of Alaska }\end{array}$ & $\begin{array}{c}10 / 31 / 85 \\
50 \text { FR } 45574 \\
\text { O1/26/88 } \\
53 \text { FR } 2208^{\star \star}\end{array}$ & $\begin{array}{c}05 / 18 / 88 \\
53 \text { FR } 17902\end{array}$ & $09 / 01 / 88$ & & & & & $\begin{array}{l}\text { Proposed } \\
09 / 90 \\
\text { Deferred }\end{array}$ \\
\hline $\begin{array}{l}117 . \\
\text { North Aleutian Basin }\end{array}$ & & & & & & & & Deferred \\
\hline $\begin{array}{l}\text { 124, } \\
\text { Beauton Sea }\end{array}$ & & $\begin{array}{c}09 / 14 / 88 \\
53 \text { FR } 35632\end{array}$ & $12 / 23 / 88$ & $\begin{array}{c}03 / 14 / 90 \\
55 \text { FR } 9513\end{array}$ & $09 / 28 / 90$ & $11 / 19 / 90$ & $03 / 22 / 91$ & $\begin{array}{l}\text { Proposed } \\
04 / 91+\end{array}$ \\
\hline $\begin{array}{l}126 \\
\text { Chukchi } S \in \lambda\end{array}$ & & $\begin{array}{c}01 / 13 / 89 \\
54 \text { FR } 1633\end{array}$ & $05 / 09 / 89$ & $\begin{array}{l}07 / 20 / 90 \\
5 \text { FR } 29680\end{array}$ & $01 / 25 / 91$ & $03 / 27 / 91$ & $07 / 26 / 91$ & $\begin{array}{l}\text { Proposed } \\
05 / 91+\end{array}$ \\
\hline $\begin{array}{l}120, \\
\text { Norton Basin }\end{array}$ & $\begin{array}{c}04 / 30 / 87 \\
52 \text { FR } 15932 \\
\text { O5/15/87 } \\
52 \text { FR } 18495^{\star} \\
01 / 13 / 89 \\
54 \text { FR } 1627\end{array}$ & & & & & & & Deferred \\
\hline $\begin{array}{l}\text { 129, } \\
\text { Shumagin }\end{array}$ & $\begin{array}{c}06 / 13: 89 \\
54 \text { FR } 25218\end{array}$ & & & & & & & $\begin{array}{l}\text { Proposed } \\
\text { Deferred }\end{array}$ \\
\hline $\begin{array}{l}\text { 133, } \\
\text { Hope Basin }\end{array}$ & & & & & & & & $\begin{array}{l}\text { Proposed } \\
\text { Deferred }\end{array}$ \\
\hline $\begin{array}{l}130, \\
\text { Navarin Basin }\end{array}$ & & & & & & & & $\begin{array}{l}\text { Proposed } \\
\text { Deferred }\end{array}$ \\
\hline 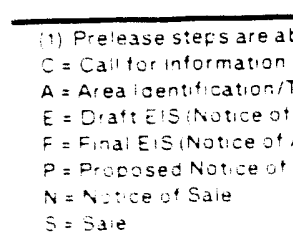 & $\begin{array}{l}\text { boreviated for brevi } \\
\text { \&N minations \& No } \\
\text { Tentative Tract SelE } \\
\text { Avaliability) } \\
\text { Avallability) } \\
\text { Sale (Notice of Aval }\end{array}$ & $\begin{array}{l}\text { Jityin this table as } \\
\text { lotice of intent to Pr } \\
\text { ectic. Pubic Anno } \\
\text { allability: }\end{array}$ & $\begin{array}{l}\text { follows: } \\
\text { repare an EIS } \\
\text { uncement) }\end{array}$ & $\begin{array}{l}\text { - Correction } \\
\text { - Date chang } \\
\text { *. Request fo } \\
\text { * Supplemen } \\
\text { + Contact Ch } \\
\text { formore in }\end{array}$ & $\begin{array}{l}\text { ge } \\
\text { or supplement } \\
\text { ntal sales may } \\
\text { hief. Otfshore } \\
\text { nformation. }\end{array}$ & $\begin{array}{l}\text { alintormation } \\
\text { or maynot cont } \\
\text { Leasing Manag }\end{array}$ & $\begin{array}{l}\text { ain OCS acreag } \\
\text { ement Division }\end{array}$ & $\begin{array}{l}\text { e offshore Alaska } \\
\text { (202) 208-6906 }\end{array}$ \\
\hline
\end{tabular}




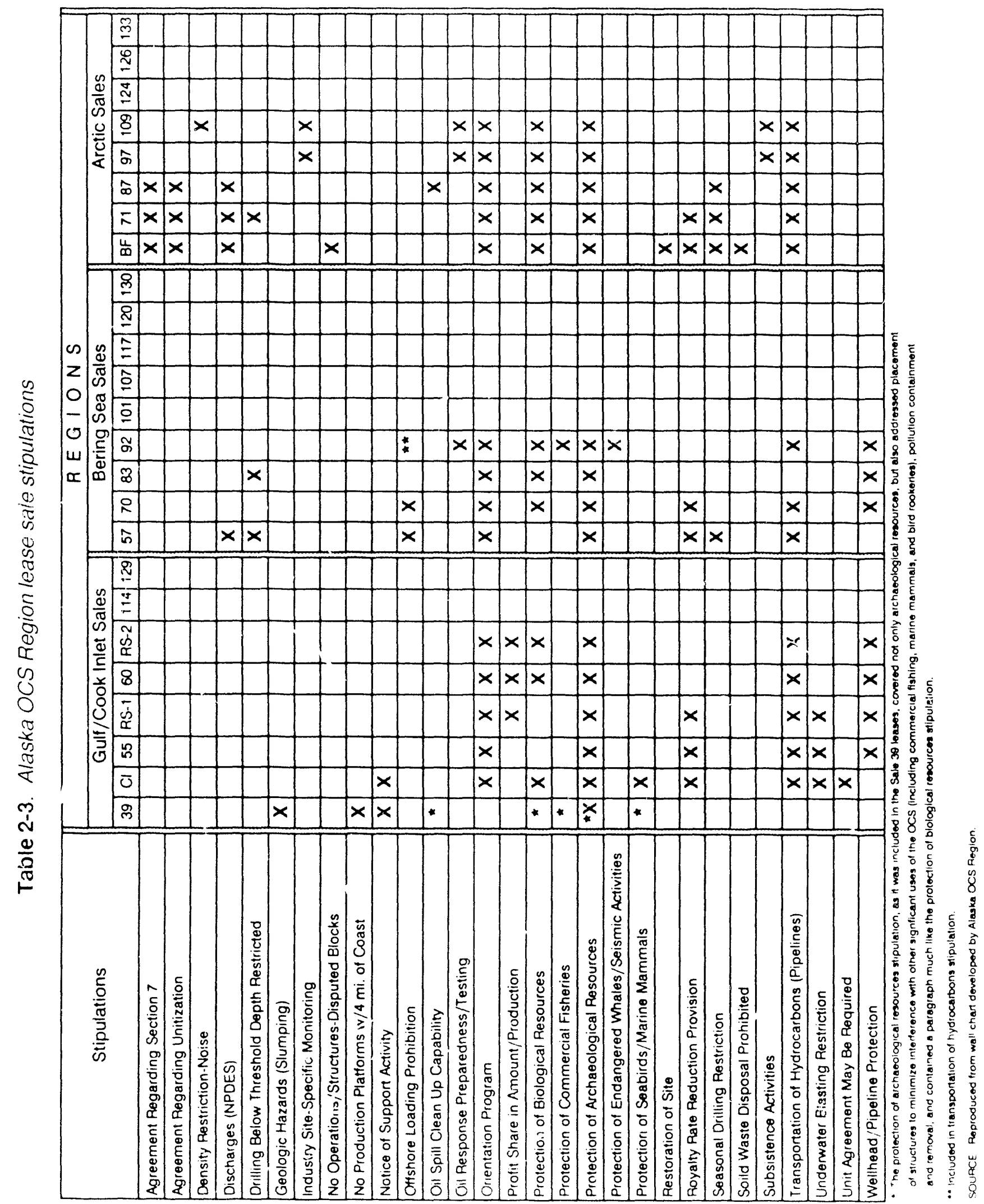




\section{Atlantic OCS Region}

Ten OCS lease sales have occurred in the Atlantic OCS Region; the first, Lease Sale 5, was held in 1959. The 10) sales offered over $51 \mathrm{mil}$ lion acres, leased 433 tracts, and received over $\$ 2.8$ billion in high bonus bids. One of the 10 sales, Lease Sale RS-2, reoffered acreage from two previous Atlantic lease sales, South Atlantic Lease Sale 56 and Mid-Atlantic Lease Sale 59. Thirteen offshore oil companies owned 61 Icase:; on the Atlantic OCS as of October 31 , 199 (). Figure $2-8$ (right) shows the top 10 Atlantic OCS leascholders by percentages of acreage held. Detailed information on Atlantic OCS lease sales is presented in tables 2-4 $1 \mathrm{p}$. 72) and $2-5$ (p. 73).

Industry interest in the Atlantic has decreased becatise of (1) leasing moratoria and numerous subarea deferrals. (2) failure to locate commercial yuantities of oil or natural gas, and (3) growing local opposition making permitting more difficult and costly. The last lease sale, Sale 78, was held in 1983. The current 5-year program scheduled five sales for the Atlantic OCS Region. Sale 140 in the Straits si Florida Planning Ared and Sale 96 in the North Atlantic Planning Area have been canceled. Sale 96 $w$ as part of the Presidential decision announced on June 26, 199(), in which several other sales in other planning areas were also canceled. As part of the decision to cancel Sale 96, located in the Georges Bank area off New England, it was also decided that no sales would occur in this area before the year 2000 , but the environmental studies in the area will continue.

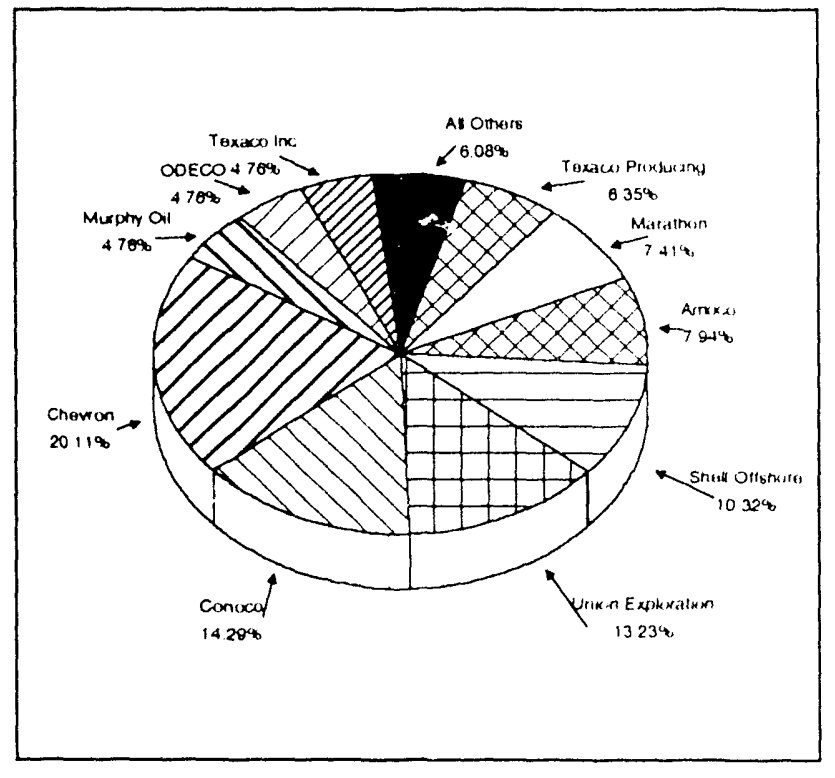

Figure 2-8. Top Atlantic OCS leaseholder by percentage of acreage held as of October 31, 1990. 
Table 2-4. Dates of and Federal Register notices for significant prelease steps for Atlantic OCS lease sales through October 31, 1990

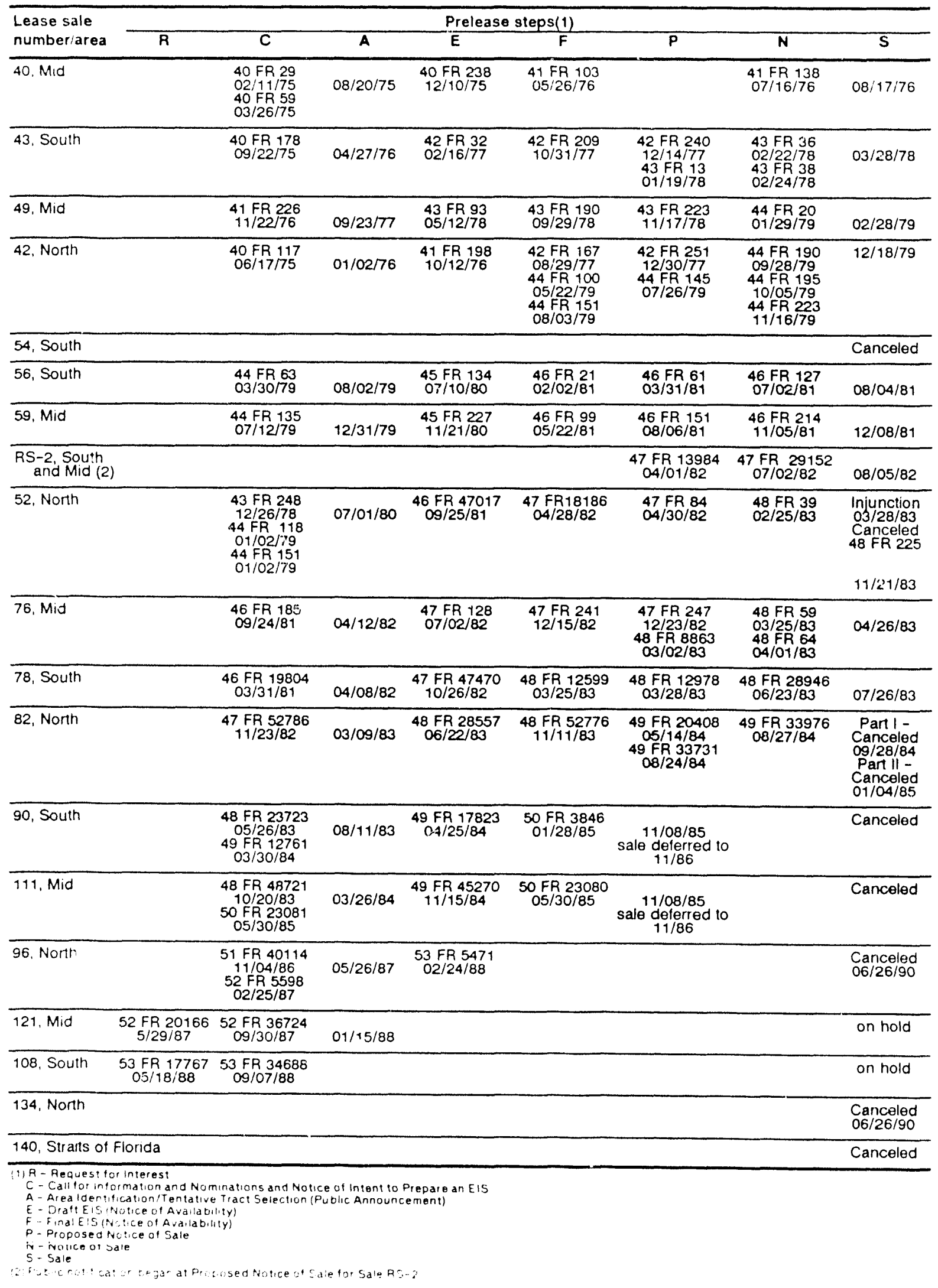


Table 2-5. Lease sale history of the Atlantic OCS Region as of October 31, 1990

\begin{tabular}{|c|c|c|c|c|c|c|c|c|c|c|}
\hline $\begin{array}{l}\text { Lease } \\
\text { sale }\end{array}$ & $\begin{array}{l}\text { Sals } \\
\text { date }\end{array}$ & $\begin{array}{l}\text { Tracts } \\
\text { offered }\end{array}$ & $\begin{array}{l}\text { Acres } \\
\text { otfered } \\
\text { (1) }\end{array}$ & $\begin{array}{l}\text { No. of } \\
\text { blds } \\
\text { rec'd }\end{array}$ & $\begin{array}{l}\text { Tracts } \\
\text { leased }\end{array}$ & $\begin{array}{c}\text { Acres } \\
\text { leased } \\
\text { (1) }\end{array}$ & $\begin{array}{c}\text { Total \$ bonus } \\
\text { leased tracts } \\
\text { (2) }\end{array}$ & $\begin{array}{c}\text { Average \$ } \\
\text { bonus } \\
\text { per acre } \\
\text { (2)(3) }\end{array}$ & $\begin{array}{l}\text { Existing } \\
\text { leases }^{\star}\end{array}$ & $\begin{array}{c}\text { Explor- } \\
\text { atory } \\
\text { wells } \\
\text { drilled }\end{array}$ \\
\hline \multicolumn{11}{|c|}{ North Atlantlc } \\
\hline \multirow[t]{2}{*}{42} & $12 / 18 / 79$ & 116 & 660,409 & 189 & 63 & 358,671 & $816,516,546$ & $\$ 2,277$ & 0 & 8 \\
\hline & Subtotal & 116 & 660,409 & 189 & 63 & 358,671 & $816,516,546$ & $\$ 2,277$ & 0 & 8 \\
\hline \multicolumn{11}{|c|}{ Mld-Atlantlc } \\
\hline 40 & $08 / 17 / 76$ & 154 & 876,750 & 410 & 93 & 529,466 & $1,: 27,936,425$ & $\$ 2,130$ & 0 & 27 \\
\hline 49 & $02 / 28 / 79$ & 109 & 620,557 & 74 & 39 & 222,034 & $40,001,631$ & $\$ 180$ & 0 & 1 \\
\hline 59 & $12 / 08 / 81$ & 253 & $1,440,376$ & 240 & 51 & 290,352 & $323,659,000$ & $\$ 1,115$ & 0 & 4 \\
\hline RS-2 & $08 / 05 / 82$ & 155 & 882,444 & 19 & 18 & 102,477 & $3,920,828$ & $\$ 38$ & 1 & 0 \\
\hline \multirow[t]{2}{*}{76} & $04 / 26 / 83$ & 4,050 & $22,664,991$ & 53 & 37 & 210,641 & $68,410,240$ & $\$ 325$ & 8 & 0 \\
\hline & Subtotal & 4,721 & $26,485,118$ & 796 & 238 & $1,354,970$ & $1,563,928,124$ & $\$ 1,154$ & 9 & 32 \\
\hline \multicolumn{11}{|c|}{ South Atlantlc } \\
\hline 43 & $03 / 28 / 78$ & 224 & $1,275,273$ & 99 & 43 & 244,807 & $100,743,443$ & $\$ 412$ & 0 & 6 \\
\hline $56^{\star}$ & $08 / 04 / 81$ & 285 & $1,621,901$ & 120 & 47 & 267,580 & $342,766,174$ & $\$ 1,281$ & 40 & 0 \\
\hline $\mathrm{RS}-2^{*}$ & $08 / 05 / 82$ & 232 & $1,320,819$ & 9 & 8 & 45,545 & $2,859,150$ & $\$ 63$ & 1 & 0 \\
\hline \multirow[t]{2}{*}{$78^{\star}$} & $07 / 26 / 83$ & 3,582 & $20,156,426$ & 12 & 11 & 62,625 & $13,362,040$ & $\$ 213$ & 11 & 0 \\
\hline & Subtolur & 4,323 & $24,374,419$ & 240 & 109 & 620,557 & $459,730,807$ & $\$ 741$ & 52 & 6 \\
\hline \multicolumn{11}{|c|}{ Stralts of Florlda } \\
\hline \multirow[t]{2}{*}{5} & 05/26/59 & 80 & 458,000 & 23 & 23 & 132,480 & $1,711,872$ & $\$ 13$ & 0 & 3 \\
\hline & Subtotal & 80 & 458,000 & 23 & 23 & 132,480 & $1,711,872$ & $\$ 13$ & 0 & 3 \\
\hline \multicolumn{2}{|c|}{ Total All Sales } & 9,240 & $51,977,946$ & 1,248 & 433 & $2,466,678$ & $2,841,887,349$ & $\$ 1,152$ & 61 & 49 \\
\hline
\end{tabular}




\section{Gulf of Mexico OCS Region}

The Gulf of Mexico OCS Region is the most active region in the offshore leasing program. Since 1954, the Gulf of Mexico OCS Region has held 66 oil and gas lease sales, offered over 6.51 million acres, and received approximately $\$ 43$ billion dollars in high bonus bids for the 9.927 tracts leased. In addition to the oil and gas lease sales, the Gulf of Mexico OCS Region has held two sulphur lease sales, two salt lease sales, and one sulphur and salt lease sale. A total of 6,829 leases within the Gulf of Mexico OCS Region were owned by 472 companies as of October 31, 1990. Figure 2-9 (right) show's the top 10 Gulf of Mexico OCS leaseholders by percentages of acreage held. Table 2-6 (p. 75) summarizes all of the oil and gas lease sales held in the Gulf of Mexico OCS Region.

Twelve OCS lease sales were scheduled under the July 1987 Five-Year Program for the Gulf of Mexico OCS Region. Of these 12 sales, 8 have already been held. Detailed information on the most recent sales, Lease Sale 123, Central Gulf of Mexico, held March 21, 1990, and Lease Sale 125, Western Gulf of Mexico, held August, 22, 199(), is presented in the sidebars on page 76. Table 2-7 (p. 76) shows the dates of the public notices for the prelease steps that have already occurred for these upcoming sales, as well as some recently held sales.

Specific information on past Gulf of Mexico lease sales can be obtained from the following office:

Depmey Chief, Office of Program Services

Gull of Mexico OCS Office

Mnincrals Management Service

1201 Elmwood Park Blid.

Nill Orleans, LA 70123-2394

Telephone: $15(1) 4 ; 736-2617$

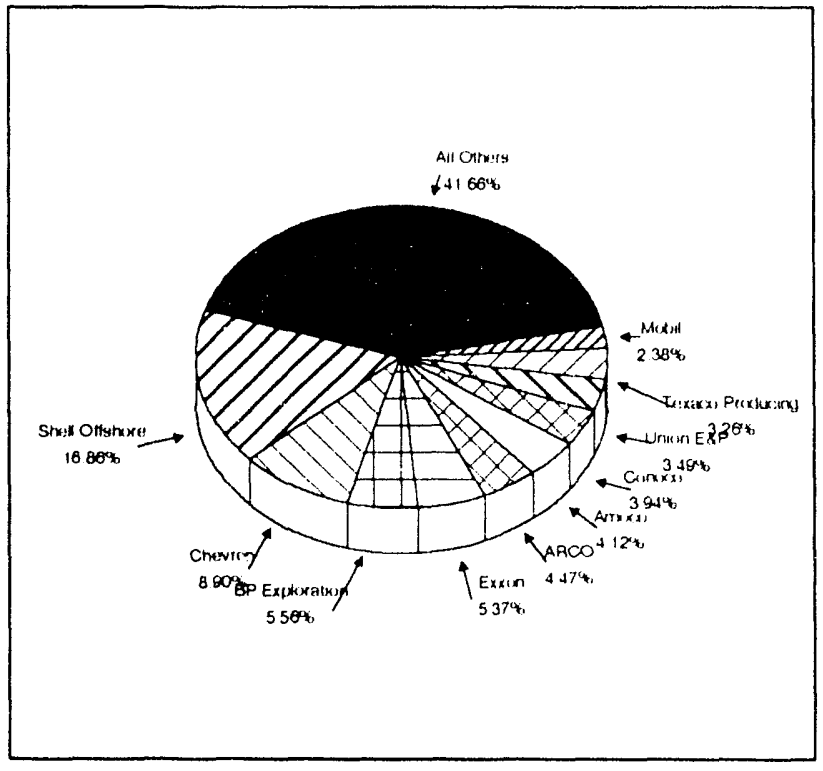

Figure 2-9. Major Gulf of Mexico OCS leaseholders by percentage of acreage held as of October 1990. 
Table 2-6. Lease sale history of the Gulf of Mexico OCS Region as of October 31, 1990

\begin{tabular}{|c|c|c|c|c|c|c|c|c|c|c|}
\hline $\begin{array}{c}\text { Lease } \\
\text { sale }\end{array}$ & $\begin{array}{c}\text { Sale } \\
\text { area } \\
(1) \\
\end{array}$ & $\begin{array}{l}\text { Sale } \\
\text { date }\end{array}$ & $\begin{array}{l}\text { Tracts } \\
\text { offered }\end{array}$ & $\begin{array}{c}\text { Acres } \\
\text { offered } \\
(2) \\
\end{array}$ & $\begin{array}{l}\text { No. of } \\
\text { blds } \\
\text { rec'd }\end{array}$ & $\begin{array}{l}\text { Tracts } \\
\text { leased }\end{array}$ & $\begin{array}{l}\text { Acres } \\
\text { leased } \\
(2)\end{array}$ & $\begin{array}{c}\text { Total } \$ \text { bonus } \\
\text { leased tracts } \\
(3)\end{array}$ & $\begin{array}{c}\text { Average } \$ \\
\text { bonus } \\
\text { per acre (3) }\end{array}$ & $\begin{array}{l}\text { Existing } \\
\text { leases } \\
(4) \\
\end{array}$ \\
\hline 1 & C & $10 / 13 / 54$ & 199 & 748,819 & 336 & 90 & 394,721 & $116,378,476$ & 295 & 32 \\
\hline 2 & W & $11 / 09 / 54$ & 38 & 111,789 & 90 & 19 & 67,149 & $23,357,029$ & 348 & 6 \\
\hline 3 & $C / W$ & $07 / 12 / 55$ & 210 & 674,095 & 384 & 121 & 402,567 & $108,528,726$ & 270 & 23 \\
\hline 5 & $E$ & $05 / 26 / 59$ & 80 & 458,000 & 23 & 23 & 132,480 & $1,711,872$ & 13 & 0 \\
\hline 6 & C & $08 / 11 / 59$ & 38 & 81,813 & 56 & 19 & 38,820 & $88,035,120$ & 2,267 & 7 \\
\hline 7 & $C / W$ & $02 / 24 / 60$ & 385 & $1,610,254$ & 444 & 147 & 704,526 & $282,641,815$ & 350 & 63 \\
\hline 9 & C & $03 / 13 / 62$ & 401 & $1,808,276$ & 538 & 206 & 956,407 & $177,260,305$ & 185 & 73 \\
\hline 10 & C/W & $03 / 16 / 62$ & 410 & $1,875,984$ & 666 & 205 & 956,592 & $268,333,397$ & 281 & 67 \\
\hline $1 i$ & C & $10 / 09 / 62$ & 19 & 33,855 & 26 & 9 & 16,178 & $43,887,359$ & 2.713 & 4 \\
\hline 12 & C & $04 / 28 / 64$ & 28 & 34,028 & 69 & 23 & 32,671 & $60,340,626$ & 1,847 & 15 \\
\hline 14 & C & $03 / 29 / 66$ & 18 & 35,993 & 64 & 17 & 35,056 & $88.845,963$ & 2,534 & 11 \\
\hline 15 & C & $10 / 18 / 66$ & 52 & 227,898 & 79 & 24 & 104,717 & $99,164,930$ & 947 & 10 \\
\hline 16 & C & $06 / 13 / 67$ & 206 & 971,489 & 743 & 158 & 744,456 & $510,079,178$ & 685 & 43 \\
\hline 18 & $W$ & $05 / 21 / 68$ & 169 & 728,551 & 556 & 110 & 541,304 & $593,899,046$ & 1,097 & 10 \\
\hline 19 & C & $11 / 19 / 68$ & 26 & 46,824 & 38 & 16 & 29,679 & $149,868.789$ & 5,050 & 4 \\
\hline $19 \mathrm{~A}$ & $\mathrm{C}$ & $01 / 14 / 69$ & 38 & 96,389 & 40 & 20 & 48,504 & $44,037,339$ & 908 & 6 \\
\hline $19 B$ & C & $12 / 16 / 69$ & 27 & 93,764 & 58 & 16 & 60,153 & $66,908,196$ & 1,112 & 10 \\
\hline 21 & C & $07 / 21 / 70$ & 34 & 73,360 & 59 & 19 & 44,642 & $97,769,013$ & 2,190 & 9 \\
\hline 22 & C & $12 / 15 / 70$ & 127 & 593,485 & 1,043 & 119 & 553,898 & $847,295,760$ & 1,530 & 56 \\
\hline 23 & C & $11 / 04 / 71$ & 18 & 55,872 & 33 & 11 & 37.222 & $96,304,523$ & 2,587 & 6 \\
\hline 24 & C & $09 / 12 / 72$ & 78 & 366,682 & 324 & 62 & 290,321 & $585,827,925$ & 2,018 & 11 \\
\hline 25 & C & $12 / 19 / 72$ & 132 & 604,029 & 690 & 116 & 535,874 & $1,665,519,631$ & 3,108 & 48 \\
\hline 26 & $\mathrm{C} / \mathrm{W}$ & $06 / 19 / 73$ & 129 & 697,643 & 551 & 100 & 547.173 & $1,591,397,380$ & 2.908 & 40 \\
\hline 32 & $E$ & $12 / 20 / 73$ & 147 & 817,297 & 373 & 87 & 485,397 & $1,491,065,231$ & 3,072 & 2 \\
\hline 33 & C & $03 / 28 / 74$ & 206 & 930.918 & 402 & 91 & 421,218 & $2,092,510,854$ & 4,968 & 52 \\
\hline 34 & $W$ & $05 / 29 / 74$ & 245 & $1,355,678$ & 352 & 102 & 565,112 & $1,471,851,831$ & 2,605 & 46 \\
\hline S1 & $\mathrm{C} / \mathrm{W}$ & $07 / 30 / 74$ & 258 & $1,298,739$ & 57 & 19 & 100,241 & $30,236,800$ & 302 & 3 \\
\hline 36 & C & $10 / 16 / 74$ & 287 & $1,370,031$ & 330 & 136 & 634.832 & $1,427,242,455$ & 2,248 & 75 \\
\hline $36(R)$ & C & $10 / 16 / 74$ & 10 & 51,515 & 57 & 8 & 40,755 & $1,018,875$ & 25 & 0 \\
\hline 37 & $W$ & $02 / 04 / 75$ & 515 & $2,870,344$ & 281 & 113 & 626,585 & $274,690,955$ & 438 & 20 \\
\hline 38 & $C / W$ & $05 / 28 / 75$ & 283 & $1,346,432$ & 191 & 86 & 406,942 & $232,916,050$ & 572 & 35 \\
\hline $38 \mathrm{~A}$ & $C: W$ & $07 / 29 / 75$ & 345 & $1,772,958$ & 179 & 66 & 336,301 & $163,214,006$ & 485 & 29 \\
\hline 41 & GOM & $02 / 18 / 76$ & 132 & 687.604 & 81 & 34 & 161,286 & $175,976,493$ & 1,091 & 13 \\
\hline 44 & C.W & $11 / 16 / 76$ & 61 & 254,488 & 117 & 43 & 178,127 & $379,148,962$ & 2,129 & 26 \\
\hline 47 & GOM & $06 / 23 / 77$ & 223 & $1,074,536$ & 424 & 124 & 605,427 & $1,170,093,432$ & 1,933 & 50 \\
\hline 45 & CW & $04 / 25 / 78$ & 145 & 709,727 & 283 & 90 & 438,756 & $733,656,893$ & 1,672 & 22 \\
\hline 65 & GOM & $10 / 31 / 78$ & 89 & 511,709 & 62 & 35 & 201,295 & $61,176,730$ & 304 & 0 \\
\hline 51 & C:W & $12 / 19 / 78$ & 128 & 643,987 & 288 & 81 & 412.416 & $871,464,998$ & 2,113 & 36 \\
\hline 58 & GOM & $07 / 31 / 79$ & 123 & 577,517 & 316 & 81 & 391,183 & $1,247,489,022$ & 3,189 & 39 \\
\hline $58 \mathrm{~A}$ & GOM & $11 / 27 / 79$ & 124 & 588,601 & 322 & 90 & 421,519 & $1,913,337,938$ & 4.539 & 31 \\
\hline A62 & GOM & $09 / 30 / 80$ & 192 & 909,575 & 506 & 116 & 551,654 & $2,676,927,673$ & 4,853 & 44 \\
\hline 62 & GOM & $11 / 18 / 80$ & 81 & 458,308 & 268 & 67 & 383,323 & $1,417,961,511$ & 3,699 & 23 \\
\hline A66 & GOM & $07 / 21 / 81$ & 212 & $1,077,931$ & 419 & 156 & 799,912 & $2,649,628,752$ & 3,312 & 53 \\
\hline 66 & GOM & $10 / 20 / 81$ & 209 & $1,081,364$ & 233 & 102 & 508,301 & $1,243,468,752$ & 2,446 & 29 \\
\hline 67 & GOM & $02 / 09 / 82$ & 234 & $1,219,847$ & 290 & 115 & 590,265 & $1,193,654,719$ & 2,022 & 43 \\
\hline $69 \mathrm{Pt} 1$ & GOM & $11 / 17 / 82$ & 144 & 732,570 & 151 & 56 & 281,213 & $609,178,223$ & 2,166 & 25 \\
\hline $69 \mathrm{Pl} 2$ & GOM & $03 / 08 / 83$ & 125 & 665,478 & 20 & 11 & 58.120 & $37,570,900$ & 646 & 4 \\
\hline 72 & C & $05 / 25 / 83$ & 7,050 & $37,867,762$ & 1,015 & 623 & $3,089,872$ & $3,367,606,134$ & 1,090 & 261 \\
\hline 74 & $W$ & $08 / 24 / 83$ & 5,848 & $32,620,248$ & 773 & 406 & $2,246,005$ & $1,501,712,517$ & 668 & 122 \\
\hline 79 & $E$ & $01 / 05 / 84$ & 8,868 & $50,631,513$ & 226 & 156 & 897,786 & $310,586,261$ & 346 & 146 \\
\hline 81 & C & $04 / 24 / 84$ & 6,502 & $34,743,780$ & 793 & 453 & $2,278,179$ & $1,323,036,649$ & 581 & 401 \\
\hline 84 & $W$ & $07 / 18 / 84$ & 5,446 & $30,038,593$ & 593 & 361 & $1,949,213$ & $844,850,488$ & 433 & 289 \\
\hline 98 & C & $05 / 22 / 85$ & 4,531 & $24,006,157$ & 644 & 409 & $2,076,908$ & $1,079,377,760$ & 520 & 401 \\
\hline 102 & $W$ & $08 / 14 / 85$ & 4,879 & $27,199,074$ & 265 & 195 & $1,075,189$ & $3.9,175,656$ & 334 & 192 \\
\hline 94 & $E$ & $12 / 18 / 85$ & 6.344 & $35,823,478$ & 114 & 77 & 421,464 & $i 19,097,298$ & 283 & 77 \\
\hline$: 04$ & C & $04 / 30 / 86$ & 5.837 & $31,382,152$ & 129 & 101 & 504,814 & $130,276,757$ & 258 & 101 \\
\hline 105 & $W$ & $08 / 27 / 86$ & 4.887 & $27,287,952$ & 52 & 41 & 229,613 & $56,817,990$ & 247 & 41 \\
\hline 110 & C & $04 / 22 / 87$ & 5,881 & $31,818,472$ & 385 & 293 & $1,539,626$ & $262,971,486$ & 171 & 291 \\
\hline 112 & $W$ & $08 / 12 / 87$ & 5,045 & $27,943,606$ & 519 & 347 & $1,908,199$ & $234,275,520$ & 116 & 347 \\
\hline 113 & C & $03 / 30 / 88$ & 6,229 & $33,580,661$ & 931 & 662 & $3,416,759$ & $388,730,457$ & 114 & 662 \\
\hline 115 & $W$ & $08 / 31 / 88$ & 5,053 & $27,911,790$ & 370 & $25 \overline{5}$ & $1,412,764$ & $125,352,889$ & 89 & 255 \\
\hline 116 & $E$ & $11 / 16 / 88$ & 8,149 & $46,417,392$ & 135 & $\$ 15$ & 657,348 & $41,582,298$ & 63 & 115 \\
\hline 118 & C & $03 / 15 / 89$ & 5.970 & $32,123,675$ & 821 & 574 & $2,892,535$ & $388,422,537$ & 134 & 574 \\
\hline 122 & $W$ & $08 / 23 / 89$ & 5.043 & $27,973,997$ & 676 & 475 & $2,688,394$ & $257,224,333$ & 96 & 475 \\
\hline 123 & C & $03 / 21 / 90$ & 5,667 & $30,493,461$ & 840 & 525 & $2,604,259$ & $424,334,314$ & 163 & 525 \\
\hline 125 & W & $08 / 22 / 90$ & 4.792 & $26,295.305$ & 465 & 300 & $1,659.187$ & $159,967,604$ & 96 & 300 \\
\hline \multicolumn{3}{|c|}{ Grand Total All Sales } & 119,401 & $651,195,114$ & 22,658 & 9,927 & $50,423,404$ & $42,548,273,401$ & & 6,829 \\
\hline
\end{tabular}

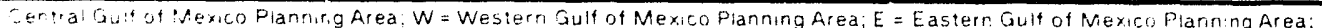

C: $W=$ entra: Q Western Plarning Area; GOM = Entire Gulf of Mexico

Dm arie ale rounded to nearestarre.

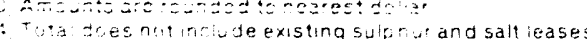

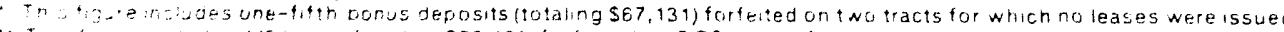

$\ldots .3$... 
Table 2-7. Dates of and Federal Register notices for significant prelease steps for recent Gulf of Mexico OCS lease sales through October 31, 1990

\begin{tabular}{|c|c|c|c|c|c|c|c|}
\hline \multirow{2}{*}{$\begin{array}{l}\text { Lease Sale } \\
\text { number/area }\end{array}$} & \multicolumn{7}{|c|}{ Prelease steps (1) } \\
\hline & $c$ & $\bar{A}$ & $\bar{E}$ & $F$ & $\bar{P}$ & $\bar{N}$ & $\mathbf{S}$ \\
\hline 118. Central & $\begin{array}{c}52 \text { FR } 21210 \\
06 / 04 / 87\end{array}$ & $08 / 28 / 87$ & $\begin{array}{c}53 \text { FR } 10299 \\
\text { C3/30/88 } \\
\star 53 \text { LR } 13332 \\
04 / 22 / 88\end{array}$ & $\begin{array}{c}53 \text { FR } 33553 \\
08 / 31 / 88\end{array}$ & $\begin{array}{c}53 \text { FR } 38364 \\
09 / 30 / 88\end{array}$ & $\begin{array}{c}54 \text { FR } 3373 \\
01 / 23 / 89\end{array}$ & $03 / 15 / 89$ \\
\hline 122, Western & $\begin{array}{c}52 \text { FR } 21210 \\
06 / 04 / 87\end{array}$ & $08 / 28 / 87$ & $\begin{array}{c}53 \text { FR } 10299 \\
03 / 30 / 88 \\
\star 53 \text { FR } 13332 \\
04 / 22 / 88\end{array}$ & $\begin{array}{c}53 \text { FR } 33553 \\
08 / 31 / 88\end{array}$ & $\begin{array}{c}54 \text { FR } 8404 \\
02,28 / 89 \\
\text { *5 FR } 29828 \\
07 / 14 / 89\end{array}$ & $\begin{array}{c}54 \text { FR } 28513 \\
07 / 06 / 89\end{array}$ & $08 / 23 / 89$ \\
\hline 123, Central & $\begin{array}{c}53 \text { FR } 18034 \\
05 / 19 / 88\end{array}$ & $08 / 09 / 88$ & $\begin{array}{c}54 \text { FR } 10738 \\
03 / 15 / 89\end{array}$ & $\begin{array}{c}54 \text { FR } 35943 \\
08 / 30 / 89\end{array}$ & $\begin{array}{c}54 \text { FR } 43342 \\
10 / 24 / 89\end{array}$ & $\begin{array}{c}55 \text { FR } 4794 \\
02 / 09 / 90\end{array}$ & $03 / 21 / 90$ \\
\hline 125, Westen & $\begin{array}{c}53 \mathrm{FR} 18034 \\
05 / 19 / 88\end{array}$ & $08 / 09 / 88$ & $\begin{array}{c}54 \text { FR } 10738 \\
03 / 15 / 89\end{array}$ & $\begin{array}{c}54 \text { FR } 35943 \\
08 / 30 / 89\end{array}$ & $\begin{array}{c}55 \text { FR } 9372 \\
03 / 13 / 90\end{array}$ & $\begin{array}{c}55 \text { FR } 29321 \\
\text { O7/18/90 }\end{array}$ & $08 / 22 / 90$ \\
\hline 131. Central & $\begin{array}{c}54 \text { FR } 18828 \\
05 / 02 / 89\end{array}$ & $08 / 29 / 89$ & $\begin{array}{c}55 \text { FR } 10847 \\
03 / 23 / 90\end{array}$ & $\begin{array}{c}55 \text { FR } 38412 \\
09 / 18 / 90\end{array}$ & $\begin{array}{c}55 \text { FR } 42075 \\
10 / 17 / 90\end{array}$ & & $(03 / 91)$ \\
\hline 135, Western & $\begin{array}{c}54 \text { FR } 18828 \\
05 / 02 / 89\end{array}$ & $08 / 29 / 89$ & $\begin{array}{c}55 \text { FR } 10847 \\
03 / 23 / 90\end{array}$ & $\begin{array}{c}55 \text { FR } 38412 \\
09 / 18 / 90\end{array}$ & & & $(08 / 91)$ \\
\hline 137, Eastern & $\begin{array}{c}54 \text { FR } 18828 \\
05 / 02 / 89\end{array}$ & $08 / 29 / 89$ & $\begin{array}{c}55 \text { FR } 10847 \\
03 / 23 / 90\end{array}$ & $\begin{array}{c}55 \text { FR } 39412 \\
09 / 18 / 90\end{array}$ & & & $(11 / 91)$ \\
\hline 139, Central & $\begin{array}{c}55 \text { FR } 18292 \\
05 / 01 / 90\end{array}$ & $08 / 07 / 90$ & & & & & \\
\hline 142, Western & $\begin{array}{c}55 \text { FR } 18292 \\
\text { O5/01/90 }\end{array}$ & $08 / 07 / 90$ & & & & & \\
\hline $\begin{array}{l}\text { Correction } \\
\text { (1) Prelease ste } \\
C=\text { Callfor Info } \\
A=\text { Area Identif } \\
E=\text { Draft FiS }(N\end{array}$ & $\begin{array}{l}\text { e abbreviated for } \\
\text { ion \& Nomination } \\
\text { on/Tentative Trac } \\
\text { e of Avallability) }\end{array}$ & $\begin{array}{l}\text { evityin this } \\
\text { Notice of in } \\
\text { election (Put }\end{array}$ & $\begin{array}{l}\text { as follows: } \\
\text { to Prepare an EIS } \\
\text { innouncervent) }\end{array}$ & $\begin{array}{l}F=\text { Final EiS } \\
P=\text { Proposed } \\
N=\text { Notice of } \\
S=\text { Sale }\end{array}$ & $\begin{array}{l}\text { lotice of Availabilit } \\
\text { lotice of Sale (Noti } \\
\text { ale }\end{array}$ & of Availability) & \\
\hline
\end{tabular}

\begin{tabular}{|c|c|}
\hline \multicolumn{2}{|c|}{ Lease Sale 123 Statistics } \\
\hline 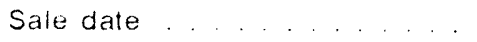 & March 21, 1990 \\
\hline 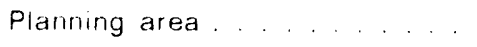 & Central GOM \\
\hline Number of tracts offered & 5,667 \\
\hline Toial acreage offered ....... & $30,493,461$ \\
\hline Number of bids received . . . . & .840 \\
\hline Number of tracts receiving bids & .538 \\
\hline Total bonuses from high bids. & $\$ 427,413,211$ \\
\hline Number of companies bidding & 96 \\
\hline $\begin{array}{l}\text { Highest bid received } \\
\text { (Vermilion, South 395) ... }\end{array}$ & $\$ 11,121,460$ \\
\hline Number of tracts leased... & .525 \\
\hline Total acreage leased . . . . . & $2,604,259$ \\
\hline Total bonuses from leased tracts & $\$ 424,334,314$ \\
\hline $\begin{array}{l}\text { Number of tracts receiving bids } \\
\text { in water depths of: }\end{array}$ & \\
\hline . $<400 \mathrm{~m}(1,312 \mathrm{tt}) \ldots$ & 401 \\
\hline - $400-900 \mathrm{~m}(1,312-2,953 \mathrm{ft})$ & 46 \\
\hline . $>900$ meters $(2,953 \mathrm{ft}) \ldots$ & 91 \\
\hline $\begin{array}{l}\text { Deepest block bid on } \\
\text { (Mississippi Canyon 977) . . }\end{array}$ & $8400 \mathrm{ft}$ \\
\hline
\end{tabular}

\section{Lease Sale 125 Statistics}

Sale date

Planning area

Number of tracts offered

August 22, 1990

Total acreage offered ..... 26,295,305

Number of bids received..... . 465

Number of tracts receiving bids. . 307

Total bonuses from high bids .... \$162,442,246

Number of companies bidding . . . 70

Highest bid received

(for Garde? Banks 117) . . . . \$ \$6,370,000

Number of tracts leased . . . . . 300

Total acreage leased . . . . . . 1,659,187

Total bonuses from leased tracts. . \$159,967,604.

Number of tracts receiving bids

in water depths of:

. $<400 \mathrm{~m}(1,312 \mathrm{ft}) \ldots 239$

- 400-900 m (1,312-2,953 H) . 41

. $>900$ meters $(2,953 \mathrm{ft}) \ldots 27$

Deepest block bid on ...... 5, 5, $125 \mathrm{ft}$

(Keathley Canyon 324)

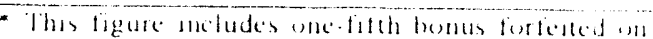
kease (; 12575 


\section{Pacific OCS Region}

Over the past 27 years, the Pacific OCS Region has held 11 lease sales, offering over 9.7 million acres. Over $\$ 3.9$ billion in high bonus bids was received for the 470 tracts $(2.5$ million acres) leased as a result of these sales. The last OCS lease sale held in the Pacific Region was Sale 80 in 1984. A total of 113 tracts were leased in the Pacific OCS Region as of October 31, 1990. Figure 2-10 (at right)) displays the top 10 leaseholders in the Pacific OCS Region by percentage of acreage held. Detailed information on Pacific OCS lease sales is presented in table $2-8$ on the next page.

The current 5-year program (1987-92) had six lease sales scheduled for the Pacific OCS Region. Five sales were proposed offshore California, and one sale was proposed offshore Washington and Oregon. As is the case in the Atlantic Region, extensive subarea deferrals have been made in the OCS planning areas offshore California as a result of 5-year program decisions. A congressionally imposed moratorium, through the appropriations process, continues to affect lease sales offshore northern California. Table 2-9 (p. 79) shows the dates of the public notices for the prelease steps that have already occurred for each of the Pacific OCS Region lease sales.

None of the Paific sales in the current 5year program have occurred. The Presidential decisions announced on June 26, 1990, canceled all Pacific sales until 1996 at the earliest. These decisions are discussed beginning on page 62 .

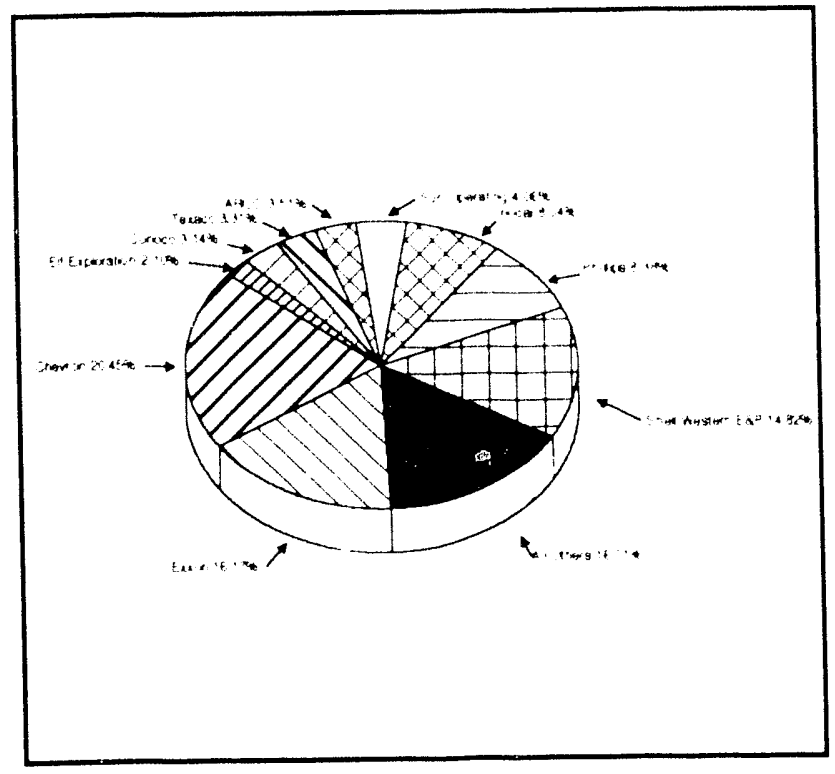

Figure 2-10. Top 10 Pacific ()CS leaseholders by percentage of acreage held as of October 31, 1990. 
Table 2-8. Lease sale history for the Pacific OCS Region as of October 31, 1990

\begin{tabular}{|c|c|c|c|c|c|c|c|c|c|c|c|c|}
\hline $\begin{array}{l}\text { Lease } \\
\text { sale }\end{array}$ & $\begin{array}{l}\text { Sale } \\
\text { area }\end{array}$ & $\begin{array}{l}\text { Sale } \\
\text { date }\end{array}$ & $\begin{array}{l}\text { Blocks } \\
\text { offered }\end{array}$ & $\begin{array}{l}\text { Acres } \\
\text { offered }\end{array}$ & $\begin{array}{l}\text { No. of } \\
\text { blds } \\
\text { rec'd }\end{array}$ & $\begin{array}{l}\text { Blocks } \\
\text { bld on }\end{array}$ & $\begin{array}{l}\text { Acres } \\
\text { bld on }\end{array}$ & $\begin{array}{l}\text { Blocks } \\
\text { leased }\end{array}$ & $\begin{array}{l}\text { Acres } \\
\text { leased }\end{array}$ & $\begin{array}{l}\text { Total } \$ \text { bonus } \\
\text { leased blocks }\end{array}$ & $\begin{array}{c}\text { Average } \\
\text { bonus } \\
\text { per acre }\end{array}$ & $\begin{array}{c}\text { Existing } \\
\text { leases }\end{array}$ \\
\hline P1 & $\begin{array}{l}\text { C. \& N. } \\
\text { CA }\end{array}$ & $05 / 14 / 63$ & 120 & 669,777 & 70 & 58 & 312,975 & 57 & 312,945 & $12,807,337$ & 41 & 0 \\
\hline P2 & WA-OR & $10 / 01 / 64$ & 196 & $1,090,074$ & 222 & 101 & 580,853 & 101 & 580,853 & $35,533,701$ & 61 & 0 \\
\hline P3 & S. CA & $2 / 15 / 66$ & 1 & 1,995 & 7 & 1 & 1,995 & 1 & 1,995 & $21,189,000$ & 10.619 & 1 \\
\hline$P_{4}$ & S. CA & $2 / 06 / 68$ & 110 & 540,609 & 164 & 75 & 383,341 & 71 & 363,181 & $602,719,262$ & 1,660 & 31 \\
\hline 35 & S. CA & $2 / 11 / 75$ & 231 & $1,257,593$ & 166 & 70 & 384,540 & 56 & 310,049 & $417,312,141$ & 1.346 & 4 \\
\hline 48 & S. CA & $6 / 29 / 79$ & 148 & 792,845 & 112 & 55 & 294,018 & 54 & 288,260 & $572,825,418$ & 1,987 & 13 \\
\hline 53 & C. $\mathrm{CA}\left(2^{\star}\right)$ & $5 / 28 / 81$ & 111 & 603,613 & 301 & 81 & 432,815 & 60 & 320,579 & $2,088,881,824 \quad(2)$ & 6,388 & 38 \\
\hline 68 & S. CA & $6 / 11 / 82$ & 140 & 716,866 & 66 & 35 & 176,253 & 29 & 147,066 & $117,875,281$ & 669 & 12 \\
\hline$R S-2(1)$ & C. $C A\left({ }^{\star}\right)$ & $8 / 05 / 82$ & 27 & 153,716 & 19 & 12 & 68,318 & 10 & 56,932 & $4,369,472$ & 77 & 2 \\
\hline 73 & c. $C A\left({ }^{\star}\right)$ & $1 / 30 / 83$ & 137 & 768,341 & 14 & 8 & 43,801 & 8 & 43,801 & $16,022,336$ & 366 & 4 \\
\hline 80 & S. CA & $0 / 17 / 84$ & 657 & $3,147,352$ & 30 & 25 & 125,100 & 23 & 114,367 & $62,121,252$ & 543 & 8 \\
\hline
\end{tabular}


Table 2-9. Dates of and Federal Register notices for significant prelease steps for Pacific OCS lease sales through October 31, 1990

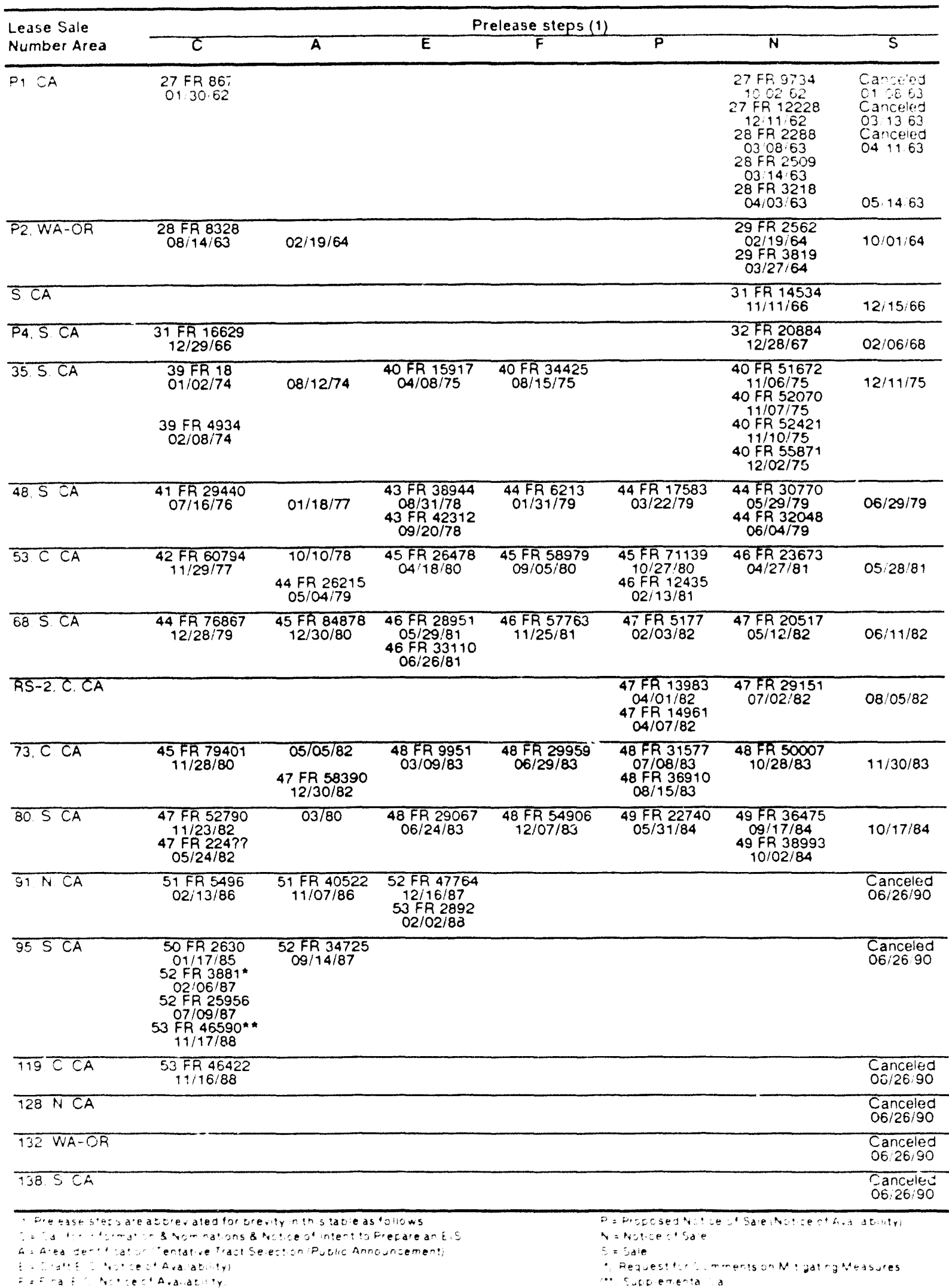




\section{Recent Lease Relinquishments}

On November 30, 1989, Conoco relinquished lease 0521, located in the Santa Barbara Channel between the cities of Santa Barbara and Ventura. The lease was issued as a result of Lease Sale 80.

On March 31, 1990, Exxon relinquished the Santa Rosa Unit, in the Santa Barbara Channel, south of Goleta. This unit included leases 0238 (from Sale P4), 0467 (Lease Sale 68, Sun), and leases 0231 and 0232 (Sale P4).

On May 22, 1990, the following Exxon leases were terminated: $0528,0529,0530$. All three were issued from Lease Sale 80 , and are located between Point Dume and Port Hueneme. Exxon also relinquished lease 0506, located in the Santa Maria Basin. This lease was issued as a result of Sale 73 . The lease term expired on July $31,1990$.

On July 31, 1990, Amoco relinquished leases 0489 anc 0490. These are located offshore San Diego and were issued as a result of Sale 68. For further information contact:

\author{
Minerals Management Service \\ Pacific OCS Region, MS-7000 \\ 770 Paseo Camarillo \\ Camarillo, CA 93010 \\ Telephone (805) 389-7502
}

\section{Environmental Studies Program}

The MMS Environmental Studies Program (ESP) was established in 1973 and was originally managed by the Bureau of Land Management. The objective of the ESP is "to establish information needed for prediction, assessment, and management of impacts on the OCS and the nearshore area which may be affected..." (43 CFR 3001.7). Contracts are dwarded for the collection and synthesis of environmental and socioxecononic infommtion to enable the Secretary to make informed OCS oil and gas leasing program decisions.
From 1973 through Fiscai Year 1990, the ESP invested over $\$ 500$ million on the collection, analysis, and dissemination of environmental and socioeconomic information. Initially, the program was designed for conducting largescale multidisciplinary baseline studies to document a variety of measurable characteristics of biological communities, the water column, and the seafloor of study areas before any OCS oil and gas activity occurs in that area. These baseline studies characterized the nature, abundance, and diversity of natural animal and plant populations, the physical characteristics of the seafloor and overlying marine waters, and the concentrations of certain trace metals and hydrocarbons in the water, sediments, and selected animals in the study areas.

The baseline or benchmark studies, in concept, were to be followed by monitoring studies to provide iniormation on environmental changes relative to the baseline data as CCS activities began in each area. During the yeais 1973-78, the ESP sponsored baseline/benchmark studies designed from an information base that was developed from literature summaries and syntheses, and supplemented with special studies for selected sites or discrete topics of special interest. During the years 1976-77, the program received its highest level of funding since studies were being initiated in the Alaska and Atlantic OCS Regions, two frontier OCS areas, in preparation for the first oil and gas lease sales in both regions. Figure 2-11 (p. 81) provides an annual comparison of the level of ESP funding received by each region from 1973 to 1990 . Figure 2-12 (p. 81) shows the percentage of the program's total 1973-90 funding expended in each OCS region, and by MMS headquarters, for generic studies. With 10 of the then 18 planning areas located in the Alaska OCS Region, nearly one-half of the ESP's funding has been expended in that region.

In late 1978, the program was redirected based on findings from both internal and external reviews, including the BLM-sponsored National Research Council (NRC) review. The 


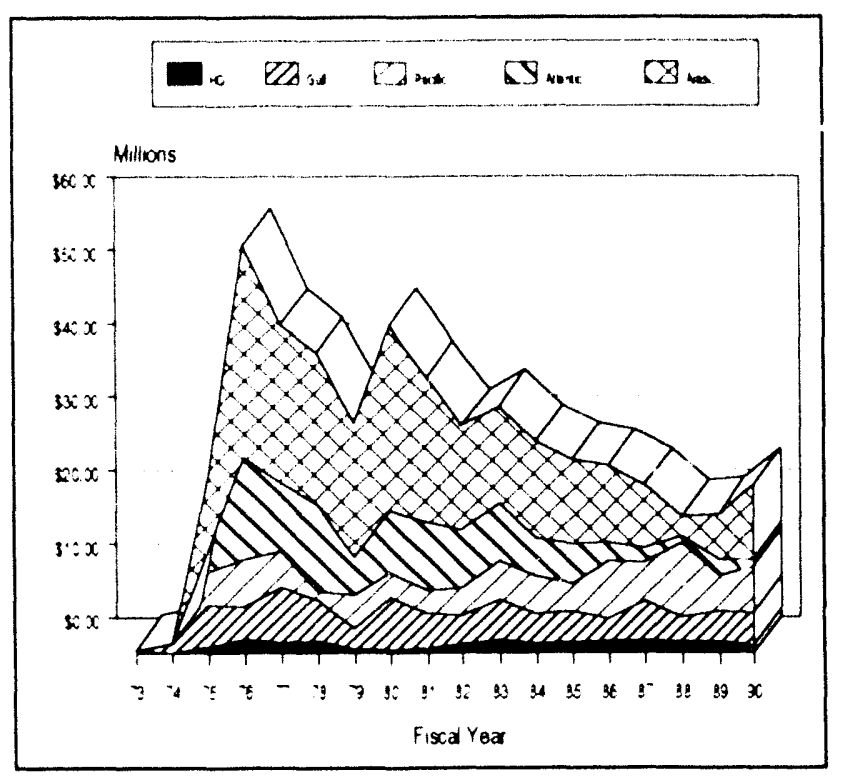

FIgure 2-11. OCS Environmental Studies Program annual level of funding received by each OCS Region, 1973-October 1990.

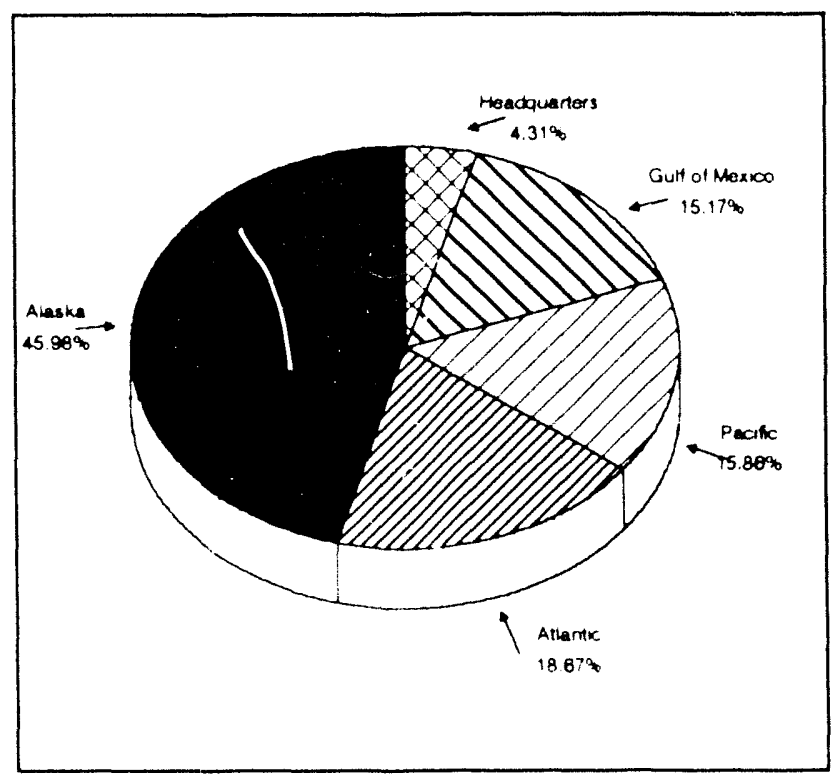

Figure 2-12. Percentage of OCS Environmental Studies Program funds distributed to each OCS Region, 1973-October 1990.
ESP was then oriented toward more immediate and useable results for leasing and lease-management decisions. A framework was developed for prioritizing study needs, and annual Regional Studies Plans were initiated. Regional Studies Plans are available from the MMS OCS regional and headquarters offices. This framework is still used in the MMS ESP, with studies plans prepared on a biannual basis beginning with Fiscal Year 1991.

From 1978 through 1985, the program's content was fairly consistent. Individual studies varied from year to year and regional emphasis changed, but there was little programmatic restructuring. Considerable emphasis was placed on field studies in physical oceanography and marine biology to characterize the ecological resources at risk in the various planning areas and to provide the data necessary for circulation modeling, and hypothetical oil-spill modeling. Toxicity studies were undertaken primarily to define lethal effects of both petroleum compounds and operational discharges from drilling rigs or production platforms. Monitoring programs were developed or initiated by all four regional oftices to determine the extent of operational impacts. Endingered species, marine mammals, and seabirds also received considerable attention. In Alaska, social and economic studies were also a significant part of the program.

In 1985, MMS initiated a major assessment of the ESP focus and future direction. Part of this reevaluation included reviewing the information generated by the ESP nn a historical basis. A draft of a report of ESP generated information from 1973-89 is being reviewed internally. The final report is expected in early 1991. In addition, the NRC was requested to review the ESP a second time and to offer advice on the future direction of the program. The NRC reports are expected to be received in 1991. For information on these reports, contact the following office: 
Ensironmental Policy \& Programs Division

Minerals Management Serice, MS 4300

381 Elden St.

Herndon, VA 22170

Telephone: (703) 787-1656

In June 1988, the General Acccunting Office (GAO) completed an audit that assessed the timeliness of studies results, user satisfaction, and efficiency of manpower utilization in the Alaska program. The report was generally favorable. Recommendations included changes in the MMS-NOAA Alaska OCS Environmental Assessment Program (OCSEAP) to consolidate project management and administrative functions within a single agency. The implementation plan for OCSEAP emphasizes in-house reseurch efforts rather than contract management activities.

At present. the ESP includes a wide variety of study approaches, including descriptive regional reconnaissance studies, site- or area-specitic studies. monitoring programs, information guthering and syntheses, and environmental process studies. The type of data and information gathered varies from study to study, but generally includes descriptive or quantitative characterizations of $(1)$ the seafloor and associated biological communities; (2) the nature and dynamics of water masses and their movement: 3 ) chemical constituents or contaminants of water, sediments. or organisms; (4) endangered or threatened species populations and their vulnerability to adverse impacts; (5) (u) atal socioeconomic structure and function and probable changes caused by OCS oil and gus activities; and (6) actual or potential cultural resource sites on the OCS. Environmental analyes are also used as part of the area evaluution process. including development of mitiguting measures and monitoring the effects of OCS uperations. Efforts are also funded to manuge available data and to provide information io interested parties. To facilitate disseminstion of information and widespread use of tudie, results, the ESP has prepared threepaye technical summaries for over $50(1)$ pro- jects. These summaries highlight the significant findings and refer the interested reader to additional references.

Figure 2-13 (below) shows the total level of funding from 1973 through 1990, by study discipline, for each OCS region and for MMS headquarters. The highest funded categories for the program through 1990 were biology and physical oceanography, and these categories will continue to be emphasized in the future.

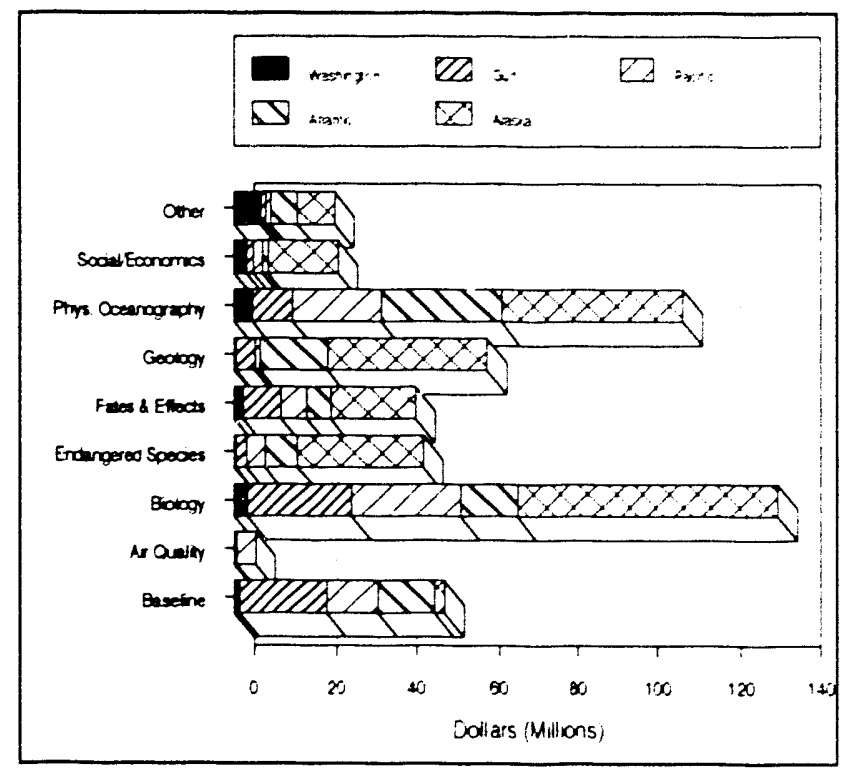

Figure 2-13. Expenditures, by discipline, for the OCS Environmental Studies Program, 1973-October 1990.

The current objectives of the ESP are as follows:

- Continue to emphasize the collection of environmental information for postlease decisions rather than prelease analyses. except in fronticr areas where environmental information is still scarce and where the potential for oil and gas leasing exists. 
- Focus studies in areas where oil and gas lease sales are being held and exploration activities are engoing or will be soon.

- Monitor, in areas where oil and gas development and production are occurring, the possible effects of such operations on the environment and local resources and concentrate on evaluating the long-term, low-level cumulative impacts of oil and gas development.

- Phase studies to provide information at the appropriate point in the decision-making process. Prelease studies emphasize more general characterizations while more site-specific studies are appropriate during postlease activities such as exploration, development, and production.

- Support studies of oil-spill impacts when appropriate and resources are available.

- Improve data accessibility, including synthesis reports, summaries, and technical position papers.

The following are the goals to be achieved through these efforts:

- Concentrate the ESP efforts in those areas where there is oil and gas activity or near-term potential for OCS development.

- Support additional pre-lease data requirements, but only after scrious evaluation of information already existing.

- Improve the flow, timeliness, and utility of information to the public, and to local, State, and Federal decisionmakers.

- Increase the efficiency of the analytical efforts including better use of existing data.

\section{Additional Readings}

Minerals Management Service. 1990. Fifteen Years of the Environmental Studies Program. Scheduled for final publication in early 1991.

Minerals Management Service. 1990. Five-Year OCS Oil and Gas Leasing Program. Draft Proposed Program. Scheduled for public release in December 1990. 


\section{Postlease Activities on the OCS}

The MMS is responsible for regulating and monitoring operations on Federal leases and for collecting all revenues due the Government. Figure 3-1 (p. 86) depicts the steps involved in the postlease phase from lease issuance through the exploration, development, and production phases to the relinquishment of a lease. On April 1, 1988, MMS consolidated all of the operational regulations related to the Offshore program into one document. The final rule was published in the Federal Register (53 FR 10596). This final rule governs all oil, gas, and sulphur exploration, development, and production operations in the OCS. The MMS laid out the following objectives in developing this rule:

- To restructure and consolidate into a single document the past lease operating requirements placed upon OCS oil, gas, and sulphur lessecs;

- To establish performance standards in preference to detailed technical standards to) the extent that protection of the environment and safety of operations permit;

- To update safety and environmental requirements, to recognize needs identified by technological advances, and to improve operating practices and experience:

- To eliminate unnecessary reporting and recordkeeping requirements; and

- To clarify and simplify the language of the rule and eliminate redundant and inappropriate provisions.

The current rule at 30 CFR 250 now contains the revised previous edition of 30 CFR 250, the individual OCS orders developed to govern operations conducted in each of the four MMS OCS Regions. and portions of selected Notices to Lessees and Operators previously issued by MMS in each of the OCS Regions.

Further information on this consolidated rulemaking is available from the following office:

Engincering \& Standards Branch

Minerals Management Service,

Room 3313A, MS 4700

381 Elden Si.

Herndon, VA 22070-4817

Telephone: (703) 787-16())

In a related effort. the MMS Office of Offshore Information \& Publications made available its publication entitled Compilation of OCS Regulations Related to Mineral Resource Activity on the Outer Continental Shelf. This loose-leaf publication compiles into one document most of the Federal regulations that affect development of the mineral resources of the OCS. For further information on, or for copies of, this publication, contact the following office:

\author{
Documents Distribution Center \\ Technical Communication Services \\ Minerals Management Service, MS 4530 \\ 381 Elden St. \\ Herndon, VA 22(07()-4817 \\ Telephone: (703) $7 \times 7-1080$
}

\section{Exploration Phase of Postlease Activities}

Following the issuance of an OCS lease, the lessee or the designated operator may apply to the MMS for approval of a lease exploration plan (EP). The EP may be for a single lease or multiple leases of the same lessec; it may also cross lease boundaries in cases where there is an approved unitization, pooling, or drilling agreement. The process that MMS employs in reviewing and approving or rejecting an applicant's EP is coutlined in figure $3-2 \mathrm{lp}$. 87). 


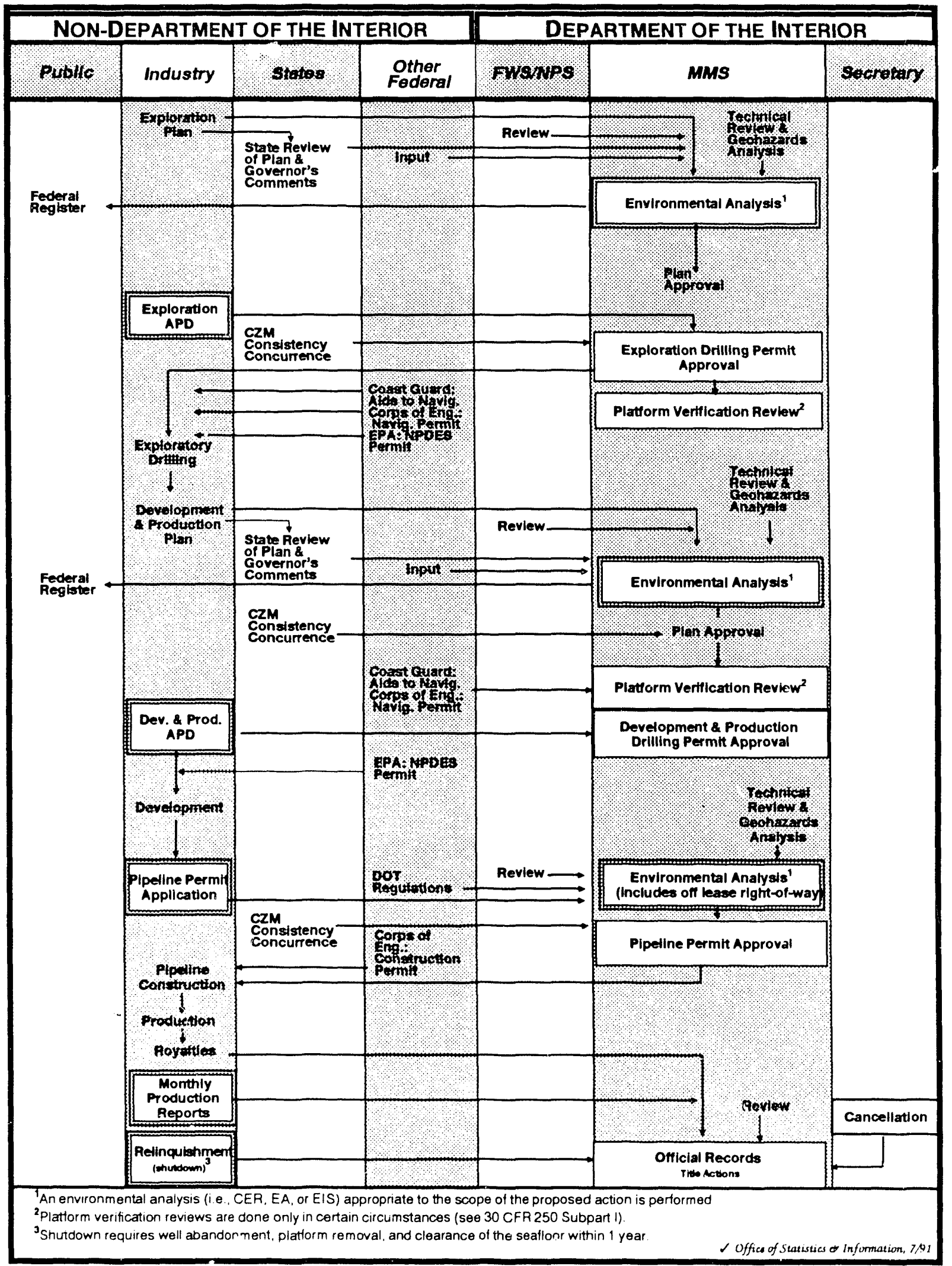

Figure 3-1. Postlease phase from lease issuance tinrough the exploration, development, and production phases to the relinquishment of a lease. 


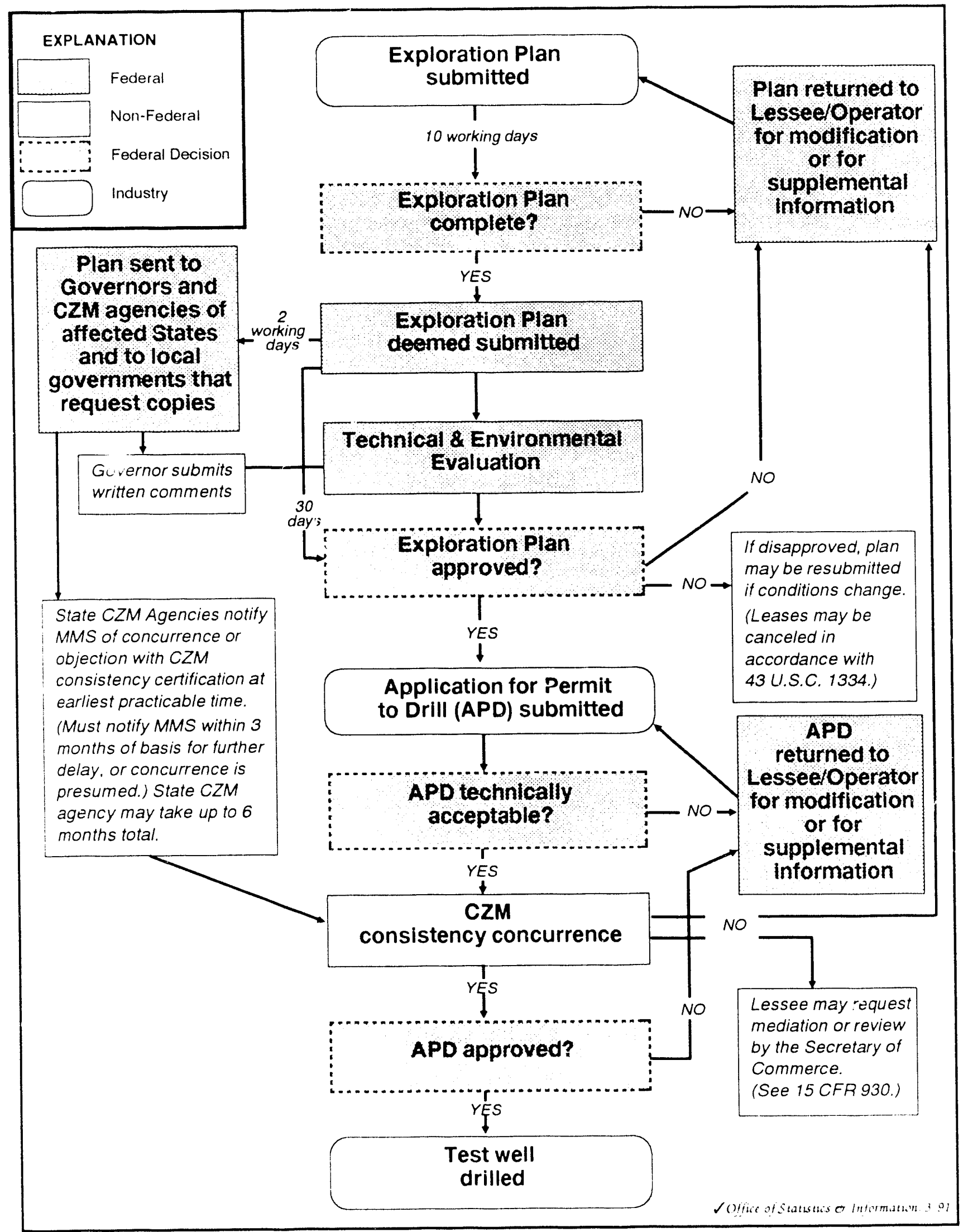

Figure 3-2. Exploration phase of postlease activities. 
Exploratory drilling on the Federal OCS reached a peak of 597 wells drilled in 1984. Following this peak, exploratory drilling declined in the mid- to late 1980 's, as the price of oil declined and operators switched their attention from exploration to development. How ever, in 1988, the level of exploratory drilling increased substantially, falling just short of the 1984 peak, with 554 wells drilled. The high level of exploratory drilling activity continued into 1989, with 498 wells drilled. This rise in exploratory drilling activity may have been due, in part, to (1) a stablization of oil prices during 1988 and 1989 and (2) an increase in exploratory drilling in the Gulf of Mexico OCS Region. The Gulf of Mexico activity was due, in part, to the large number of shallow water leases that were to expire in 1988 and 1989 (see p. 101 for more detailed information). Figure 3-3 (below) shows the number of exploratory wells drilled on the OCS from 1954 to 1989.

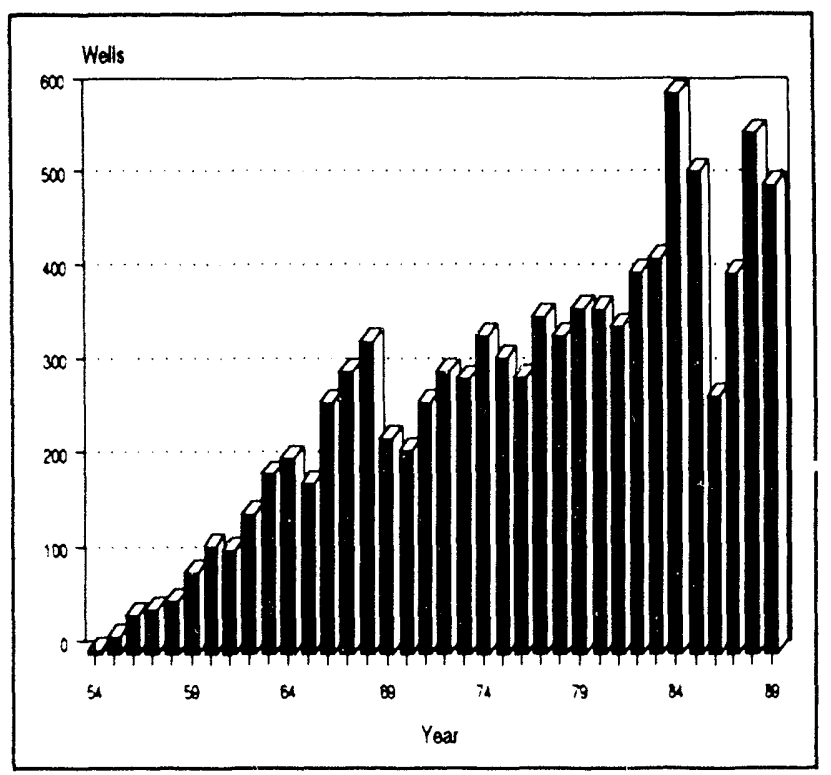

Figure 3-3. Exploratory wells drilled on the OCS, 1954-89.

\section{Alaska OCS Region}

As of October 31, 1990, a total of 73 exploratory wells had been spudded in the Alaska OCS Region. Figure 3-4 (below) graphically depicts the number of exploratory wells drilled by planning area and year on the Alaska OCS since the first well was spudded in September 1976. Table 3-1 (p. $89 \& 90$ ) lists the exploratory wells drilled in the Alaska OCS Region through October 1990. Figure 3-5 (p. 91) presents the location of each of the official protraction diagrams (OPD's) for the Alaska OCS Region. Each of these OPD's may be ordered through the Alaska OCS Regional Office at the following address:

Alaska OCS Regional Library Minerals Management Service

949 East 36th Ave., Room 110

Anchorage, AK 99508-4302

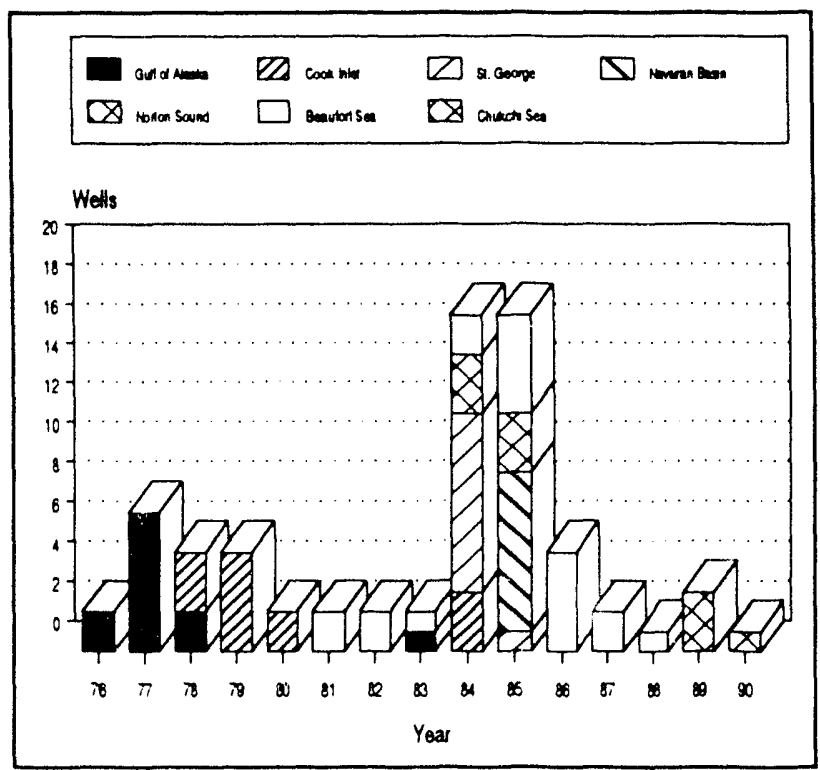

Figure 3-4. Exploratory wells drilled in the Alaska OCS Region by planning area, 1976-October 1990. 
Table 3-1. Alaska OCS drilling history as of October 31, 1990

\begin{tabular}{|c|c|c|c|c|c|c|c|c|c|c|c|c|}
\hline Sale & $\begin{array}{l}\text { Prospect } \\
\text { Unlt name } \\
\end{array}$ & Block & OPD no. & $\begin{array}{l}\text { Lease } \\
\text { no. }\end{array}$ & Operator & Rig & $\begin{array}{l}\text { Rig } \\
\text { type }\end{array}$ & $\begin{array}{l}\text { Well } \\
\text { no. }\end{array}$ & $\begin{array}{l}\text { Water } \\
\text { depth }\end{array}$ & $\begin{array}{l}\text { Spud } \\
\text { date }\end{array}$ & $\begin{array}{l}\text { P\&A } \\
\text { date }\end{array}$ & $\begin{array}{l}\text { Total } \\
\text { depth }\end{array}$ \\
\hline \multicolumn{13}{|c|}{ GULF OF ALASKA } \\
\hline & COST NO 1 & $196 \#$ & NO 7-1 & & $A R C O$ & Giomar Conception & $D$ & & 570 & $07-22-75$ & $10-09-75$ & $5 \cdot 5$ \\
\hline & KSST No. 1 & 573 & NO 5-8 & & $\mathrm{ESCl}$ & Zapata Trader & 0 & & 162 & $07-13-76$ & $08-01-76$ & 4205 \\
\hline & KSST NO 2 & 984 & NO 5-6 & & $\mathrm{ESCl}$ & Zapata Trader & $D$ & & 232 & $08-04-76$ & $08-23-76$ & 439 \\
\hline & KSST No 4 & 781 & NO 5-4 & & $\mathrm{ESCl}$ & Zapata Trader & $D$ & & 307 & $08-28-76$ & $09-19-76$ & 1391 \\
\hline 39 & Maria & 106 & & 0011 & SHEL.L & Sedco 706 & $\mathrm{~S}$ & 1 & 541 & $09-01-75$ & $01-28-77$ & 13505 \\
\hline 39 & Salome & 72 & & $\infty 007$ & ARCO & Ocean Ranger & $\mathrm{S}$ & 1 & 250 & $10-21-76$ & $06-03-77$ & 17.920 \\
\hline 39 & Yvonne & 111 & & $\infty 014$ & SHELL & Sedco 706 & $\mathrm{~S}$ & 1 & 485 & $02-11-77$ & $06-19-77$ & 13598 \\
\hline 39 & & & & & & & & $1 \mathrm{ST}$ & 485 & $06-20-77$ & $09-12-77$ & 15.390 \\
\hline 39 & Setter & 284 & & $\infty 050$ & EXXON & Alaskan Star & $\mathrm{S}$ & 1 & 585 & $03-08-77$ & $07-08-77$ & 12.995 \\
\hline 39 & Cape Suckling & 241 & & 0046 & TEXACO & Ocean Bounty & $\mathrm{S}$ & 1 & 599 & $04-15-77$ & $07-15-77$ & 15.031 \\
\hline \multirow[t]{2}{*}{39} & Wainus & 329 & & $\infty 059$ & GULF & Aleutian Key & $\mathrm{S}$ & 1 & 623 & $05-13-77$ & $08-16-77$ & 12.170 \\
\hline & KSSD No. 1 & 999 & & & SUN & Sedcc 708 & $\mathrm{~S}$ & & 600 & $05-25-77$ & $07-17-77$ & 8.517 \\
\hline 39 & Raccoon & 343 & NO 6-2 & $\infty 080$ & EXXON & Alaskan Star & $\mathrm{S}$ & 1 & 448 & $07-09-77$ & $01-04-78$ & 13.507 \\
\hline \multirow[t]{3}{*}{39} & Yakataga & 162 & NO 7-1 & $\infty 032$ & TEXACO & Ocean Bounty & $\mathrm{S}$ & 1 & 234 & $07-17-77$ & $02-20-78$ & 15.638 \\
\hline & KSSD No. 2 & 463 & NO $6-3$ & & SUN & Sedco 708 & $\mathrm{~S}$ & & 400 & $07-22-77$ & $09-08-77$ & 10.450 \\
\hline & KSSD No. 3 & 14 & NO 5-8 & & SUN & Sedco 708 & $\mathrm{~S}$ & & 280 & $09-13-77$ & $10-25-77$ & 9,355 \\
\hline 39 & Marmot & 414 & NO 7-1 & $\infty 72$ & EXXON & Alaskan Star & $\mathrm{S}$ & 1 & 863 & $01-09-78$ & $03-17-78$ & 9,835 \\
\hline 39 & Grizaly & 165 & & $\infty 035$ & EXXON & Alaskan Star & $\mathrm{S}$ & 1 & 184 & $03-23-78$ & $07-01-78$ & 11,731 \\
\hline 55 & Yakutat & 932 & NO 7-2 & 0211 & ARCO & Ocean Odyssey & & 1 & 450 & $04-10-83$ & $10-22-83$ & 17,810 \\
\hline \multicolumn{13}{|c|}{$\overline{\text { COOK }}$ INLET } \\
\hline & COST NO. 1 & 489 & NO 5-2 & & ARCO & Ocean Ranger & $S$ & & 216 & $06-10-75$ & $09-24-77$ & 12.387 \\
\hline $\mathrm{Cl}$ & Guppy & 318 & & 0086 & MARATHON & Diamond M Dragon & $D$ & 1 & 120 & $07-21-78$ & $12-22-78$ & 13.315 \\
\hline $\mathrm{Cl}$ & South Arch & 668 & & 0124 & PHILLIPS & Ocean Bounty & $S$ & 1 & 267 & $10-09-78$ & $10-19-78$ & 1,254 \\
\hline 81 & & & & & & & & $1 \mathrm{~A}$ & 267 & $10-20-78$ & $05-18-79$ & 11.294 \\
\hline $\mathrm{Cl}$ & Coho & 2 & NO 5-4 & 0168 & MARATHON & Diamond M Dragon & $D$ & 1 & 542 & $01-11-79$ & $04-27-79$ & 2,797 \\
\hline $\mathrm{Cl}$ & & & & & & & & 2 & 542 & $04-29-79$ & $08-21-79$ & 8,907 \\
\hline $\mathrm{Cl}$ & Bede & 798 & NO 5-2 & 0136 & PHILLIPS & Ocean Bounty & $S$ & 1 & 245 & $05-28-79$ & $09-18-79$ & 10.324 \\
\hline $\mathrm{Cl}$ & Hawk & 572 & NO 5-1 & 0161 & $A R C O$ & Dan Prince & $J$ & 1 & 133 & $07-15-79$ & $01-21-80$ & 14,975 \\
\hline $\mathrm{Cl}$ & Bowhead & 970 & NO 5-2 & 0152 & PHILLIPS & Ocean Bounty & $\mathrm{S}$ & 1 & 513 & $09-24-79$ & $04-26-80$ & 13,128 \\
\hline $\mathrm{Cl}$ & Raven & 401 & & 0097 & ARCO & Dan Prince & $\mathrm{J}$ & 1 & 192 & $04-06-80$ & $05-29-80$ & 7.471 \\
\hline $\mathrm{Cl}$ & Ibis & 576 & & 0113 & ARCO & Ocean Bounty & $\mathrm{S}$ & 1 & 202 & $05-09-80$ & $06-24-80$ & 7.012 \\
\hline 60 & Falcon & 225 & & 0243 & CHEVRON & Sedco 712 & $S$ & 1 & 115 & $n 9-19-84$ & $11-12-84$ & 5,574 \\
\hline 60 & Cardinal & 654 & NO 5-3 & 0248 & CHEVRON & Sedco 712 & $\mathrm{~s}$ & 1 & 550 & $11-21-84$ & $12-18-84$ & 1,890 \\
\hline 60 & & & & & & & & $1 A$ & 550 & $12-18-84$ & $03-13-85$ & 10.130 \\
\hline \multicolumn{13}{|c|}{ ST. GEORGE } \\
\hline & COST NO. 1 & $459 *$ & $N N 3-1$ & & ARCO & Ocean Ranger & $\mathbf{S}$ & & 440 & $07-02-76$ & $09-22-76$ & 13.771 \\
\hline & COST No. 2 & 390 & & & ARCO & Sedco 708 & $\mathrm{~S}$ & & 369 & $05-19-82$ & $09-02-82$ & 14,626 \\
\hline 70 & Tustemena & 809 & NO $3-7$ & 0530 & EXXON & Doo Sung & $\mathrm{S}$ & 1 & 420 & $06-29-84$ & $09-04-84$ & 8,800 \\
\hline 70 & Intrepid & 714 & & 0519 & CHEVRON & Sedco 712 & $\mathrm{~s}$ & 1 & 437 & $07-20-84$ & $09-25-84$ & 11,587 \\
\hline 70 & Rat & 889 & & 0537 & ARCO & Sedco 708 & $S$ & 1 & 436 & $08-04-84$ & $10-30-84$ & 12,456 \\
\hline 70 & Columbia & 764 & & 0527 & EXXON & Doo Sung & $\mathrm{S}$ & 1 & 421 & $09-13-84$ & $11-19-84$ & 12,433 \\
\hline 70 & Benha & 616 & NO 3-1 & 0466 & MOBIL & Sedco 712 & $\mathrm{~S}$ & 1 & 358 & $09-29-84$ & $11-03-84$ & 8.085 \\
\hline 70 & Wolf Lake & 631 & NO $3-7$ & 0511 & ARCO & Sedco 738 & $\mathrm{~S}$ & 1 & 390 & $11-07-84$ & $12-14-84$ & 10,862 \\
\hline 70 & & & & & & & & $1 A$ & 390 & $12-17-84$ & $02-14-85$ & 12.467 \\
\hline 70 & Fern & 467 & NN 3-1 & 0.454 & SHELL & Ocean Odyssey & $\mathrm{S}$ & 1 & 420 & $11-20-84$ & $01-24-85$ & 10.277 \\
\hline 70 & Camelot & 811 & & 0477 & GULF & Doo Sung & $\mathrm{S}$ & 1 & 476 & $11-27-84$ & $01-23-85$ & 9.592 \\
\hline 70 & Monkshood & 604 & & 0463 & SHELL & Ocean Odyssey & $\mathrm{s}$ & $i$ & 394 & $01-26-85$ & $03-31-85$ & 8.510 \\
\hline \multicolumn{13}{|c|}{ NOATH ALEUTIAN BASIN } \\
\hline & COST No. 1 & 666 & NO $4-7$ & & ARCO & Sedco 708 & & & 297 & $09-08-82$ & $01-14-83$ & 17,115 \\
\hline \multicolumn{13}{|c|}{ NORTON SOUND } \\
\hline & $\begin{array}{l}\text { COST No } 1 \\
\text { COST No. } 2\end{array}$ & $\begin{array}{l}197 \\
273\end{array}$ & $\begin{array}{l}\text { NP } 3-1 \\
\text { NP 3-2 }\end{array}$ & & $\begin{array}{l}\text { ARCO } \\
\text { ARCO }\end{array}$ & $\begin{array}{l}\text { Dan Prince } \\
\text { Key Singapore }\end{array}$ & $j$ & & $\begin{array}{l}065 \\
049\end{array}$ & $\begin{array}{l}06-14-80 \\
06-07-82\end{array}$ & $\begin{array}{l}09-28-80 \\
09-15-82\end{array}$ & $\begin{array}{l}14,683 \\
14,889\end{array}$ \\
\hline 57 & Chugach & 267 & & 0414 & EXXON & Middleton & J & 1 & 054 & $06-19-84$ & $07-23-84$ & 3,636 \\
\hline 57 & Birch & 949 & NQ 3-7 & 0436 & ARCO & Key Hawaii & $\mathrm{J}$ & 1 & 065 & $06-25-84$ & $08-19-84$ & 10,950 \\
\hline 57 & Teton & 448 & NP $3-2$ & 0430 & EXXON & Middleton & $\mathrm{J}$ & 1 & 035 & $07-25-84$ & $08-16-84$ & 4,951 \\
\hline 57 & Cascade & 54 & & 0398 & EXXON & Key Hawall & $\mathrm{J}$ & 1 & 058 & $07-02-85$ & $07-23-85$ & 6.913 \\
\hline 57 & Yellow Pup & 182 & & 0407 & EXXYN & Key Hawa॥ & $\mathrm{J}$ & 1 & 058 & $07-24-85$ & $08-11-85$ & 7.267 \\
\hline 57 & Chugach & 361 & NP $3-2$ & 0425 & EXXON & Key Hawaii & $J$ & 1 & 042 & $08-13-85$ & $08-24-85$ & 6.093 \\
\hline
\end{tabular}


Table 3-1. Alaska OCS drilling history as of October 31, 1990-continued

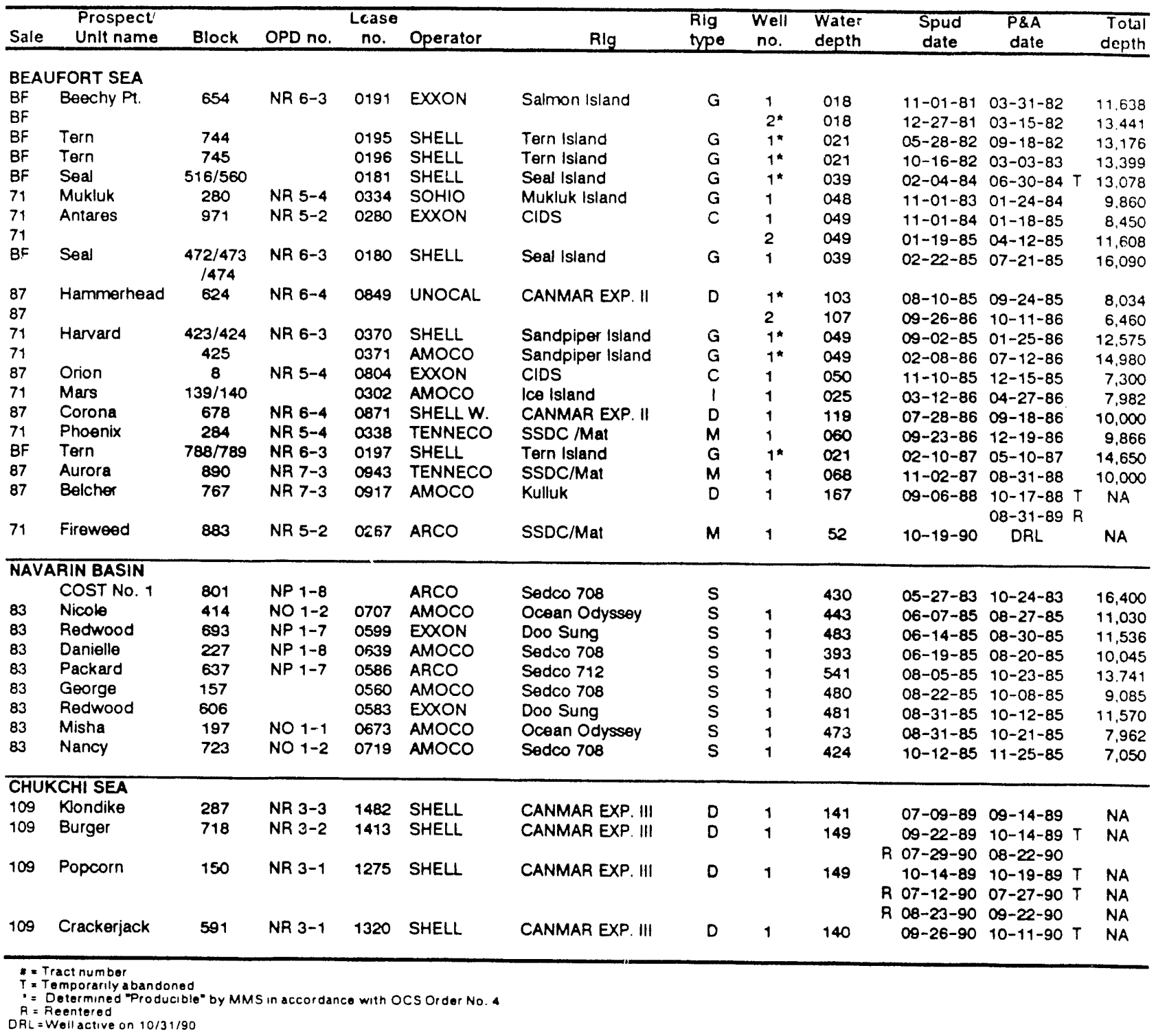

RIG TYPE KEY

$G=$ Gravelistands

1 - Spray-ice istands

$\mathrm{S}=$ Somisubm

$J$ Jackups

C Concrete island Drilling System

$M=$ Single Steol Drilling Caisson/Mal

NOTE: As used herein tho P a A date is defined as the date the casing is cut and removed from the sea lloor Repor and Lo form $9-330$. 


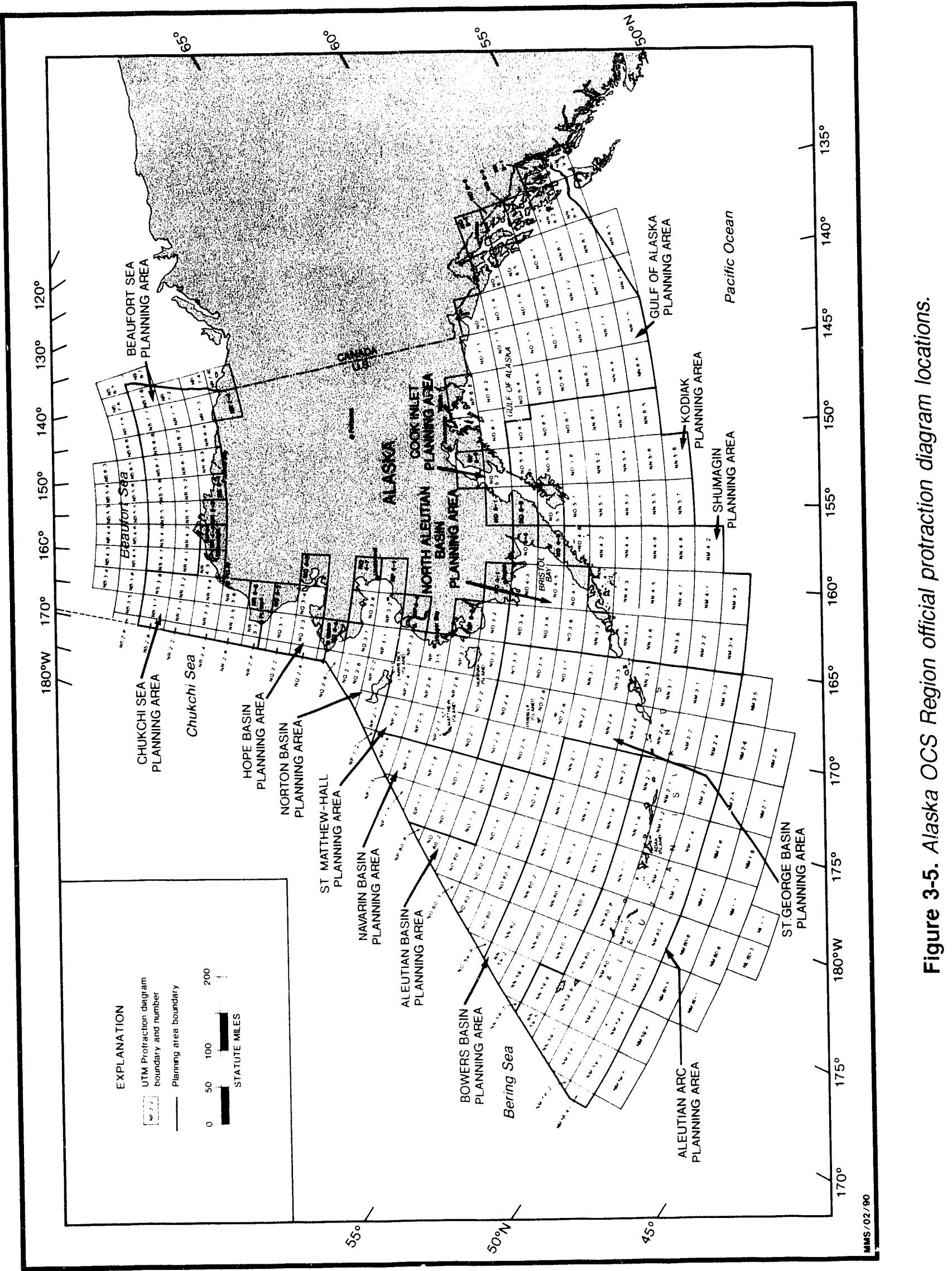


Shell Oil Company was the first to begin exploratory drilling on the Alaska OCS. Initial interest was focused in the northern Gulf of Alaska. Ten exploratory wells were drilled by five operators between 1976 and 1978, with the greatest exploratory activity occurring in the spring and summer of 1977. All of the wells were determined to be dry and were plugged and abandoned.

In 1978, interest on the Alaska OCS shifted to the lower Cook Inlet, where 10 exploratory wells were drilled between 1978 and 1980. Industry's interest in this area was high because production was occurring in nearby state waters in the upper Cook Inlet. Marathon Oil Corporation was the first to begin exploratory drilling on the lower Cook Inlet. The first well was spudded in July 1978 and had a show of oil in noncommercial volumes. The well was plugged and abandoned on December 22, 1978. Marathon drilled a second well in 1979. It was determined to be dry and was also plugged and abandoned.

Two companies other than Marathon were also active in the lower Cook Inlet. Phillips Petroleum Exploration drilled an exploratory well in three different blocks in 1978 and 1979; all three wells were dry. Atlantic Richfield Company (ARCO) also drilled three wells on the lower Cook Inlet. The first well, spudded in 1979, was dry. The second well had a show of oil that was not commercially significant, and the well was plugged and abandoned. The third well was dry and was plugged and abandoned in June 1980.

With the issuance of leases from the Joint Federal-State Beaufort Sea Lease Sale in December 1979, industry began to explore in the Salmon Island. Exxon was the first to explore in the Beaufort Sea, drilling two wells from Beechy Point, a gravel island. The gravel island was constructed during the 1981-82 drilling season and was 480) feet in diameter and 11 fect above mean high water. The first well was spudded on November 1, 1981, and was temporarily plugged and abandoned on March
31, 1982. The second well was spudded on December 27, 1981; it was temporarily plugged and abandoned on March 7, 1982. This well has been determined to be producible by MMS. (See the Determination of Well Producibility sidebar on this page for more information.) Salmon Island was abandoned by Exxon in October 1983, by permanently abandoning the wells and subsequently removing surface hardware and island slope-protection materials, allowing the island to erode naturally.

\section{Determination of Well Producibility}

Effective May 31, 1988, the MMS changed its procedures for determining well producibility. Prior to that time, an OCS operator was required to submit to MMS a well producibility determination for each exploratory well that it drilled. This requirement was articulated under what was known as OCS Order No. 4. This OCS Order, and all others, were incorporated into the MMS regulatory program effective May 31, 1988. OCS Order No. 4 became 30 CFR 250.11, "Determination of Well Producibility."

Under this new regulation, an operator is no longer required to submit an evaluation of every exploratory well drilled. However, in accordance with the terms of 30 CFR 250.11, an operator requesting an extension of lease term may request that a determination of well producibility be made for any well that the operator drills. Upon receiving a written request from the lessee, the MMS will determine whether a well is capable of producing in paying quantities (production of oil, gas, or both in quantities sufficient to yield a return in excess of the costs, after completion of the well, of producing the hydrocarbons at the wellhead). Such a determination shall be based upon a number of tests outlined within the new regulation.

These determinations are the basis of MMS's decision to extend a lease's term and are not intended to imply that a well has been determined to be commercial. The operator of the well makes the determination whether the well is commercial or noncommercial. 
Shell Western Exploration \& Production, Inc. (SWEPI) was the next operator to explore the Beaufort Sea, submitting a plan of exploration on September 25, 1981. The project, known as the Tern Prospect, received exploration plan approval on October 23, 1982. A gravel island was constructed, and two wells were drilled during the summer and fall of 1982. Both of these wells were determined producible by MMS and have been temporarily plugged and abandoned.

In 1983, two additional operators, ARCO Oil and Gas Company and Sohio, began exploration in the Alaska OCS in scarch of oil and gas. ARCO drilled a well in the Gulf of Alaska. This well, which was the last well drilled in the Gulf of Alaska, did not produce a commercial find, and was plugged and abandoned in October 1983.

On November 1, 1983, a Sohio-led consortium spudded the most expensive wildeat well in history. The Mukluk Prospect was drilled from the largest manmade gravel island in U.S. waters at a site further north (approximately 300 miles above the Arctic Circle) in deeper water (48 ft) than ever previously attempted. Results of the drilling showed no commercially producible hydrocarbons, and the well was plugged and abandoned on January 24, 1984. Mukluk Island was permanently abandoned in September 1988.

Exploratory drilling on the Alaska OCS peaked in 1984 and 1985 as the price of crude oil remained high, encouraging operators to explore new planning areas (sce fig. 3-4, p. 88). Exploration expanded to include 5 of the 15 Alaska OCS planning arcas, with a total of 34 wells being drilled by seven off shore operators (Amoco, ARCO, Chevron, Exxon, Gulf, Mobil, and Shell). The following is a listing of the number of wells drilled in each of the five Alaska OCS planning areas from 1984 to 1985 :

- In the St. George Basin, 10) wells were drilled by 6 operators. This area was the most active area off the coast of Alaska in 1984. All 10 wells were dry. The last well was plugged and abandoned on March 31, 1985.

- In the Cook Inlet, three wells were drilled by Chevron in 1984. All three were dry and were plugged and abandoned.

- In the Norton Sound, a total of six wells were drilled by two operators. ARCO drilled one well in 1984, and Exxon drilled five wells, two in 1984 and three in 1985. All six wells were dry and were plugged and abandoned.

- In the Navarin Basin, a total of eight exploratory wells were drilled by ARCO, Amoco, and Exxon. This area was the most active area off the coast of Alaska in 1985. All eight weils were dry and were plugged and abandoned.

- In the Beaufort Sea, a total of seven wells were drilled by Exxon, Shell, and Unocal. Three of these wells were determined producible by MMS, and two were temporarily abandoned. The other four wells were dry and were plugged and abandoned.

The Beaufort Sea Planning Area in 1984 and 1985 was the scene for many innovative exploration projects. The industry employed technologies from the Canadian Arctic as operators moved away from their early reliance on gravel island drilling platforms.

Exxon initiated drilling on the Antares Prospect on November 1, 1984, using the Glomar Beaufort Sea I, the Concrete Island Drilling System (CIDS). The structure and design of CIDS were discussed extensively in the Arctic Summary Report, January 1985 (Lynch, Slitor, and Rudolph, OCS Information Report MMS 8.5-(0)(22). The first well recovered noncommercial traces of oil and was plugged and abandoned. The second well, spudded in January 1985 , also showed no commercial reserves of hydrocarbons; it was plugged and abandoned on April 13, 1985. On November 10, 1985, a 
third well was spudded from CIDS, as Exxon initiated exploratory drilling of its Orion Prospect, a few miles off Point Halkett in the Beaufort Sea. This well was plugged and abandoned on December 15, 1985.

The most noteworthy facet of Exxon's work on the Antares project was the successful use of the CIDS mobile drilling structure. The Antares well was the first well drilled in the Alaskan Beaufort OCS from a platform other than a gravel island.

Shell Western E\&P, Inc. (SWEPI) initiated exploratory drilling on their Harvard Prospect on September 2, 1985. This well was drilled from the Sandpiper gravel island approximately 6 miles from shore. This well was temporarily abandoned on January 25, 1986, and has been determined producible by MMS.

SWEPI had also drilled two other wells on Seal Island in 1984 and 1985 from leases acquired during the joint Federal-State BF (Beaufort Sea) sale in 1979. The first well was spudded on February 4, 1984, and was temporarily abandoned; it has been determined producible by MMS. The second well was plugged and abandoned on July 21,1985 . As a result of drilling successes by SWEPI at Seal Island and Amerada Hess from Northstar Island 10cated to the northwest of Seal Island, a joint Federal-State Northstar Unit was formed with Amerada Hess as the designated operator with reserves under State and Federal lands. The unit agreement was approved by the State and MMS in January 1990.

Exploration drilling on the Hammerhead Prospect began on August 10, 1985, by Unocal, using the Canmar Explorer II. The Canmar drillship is a converted U.S. Navy storm class Cimari cargo ship with a steel-reinforced hull for work in waters pervaded with sea ice. This well has been determined producible by MMS; it was permanently abandoned on September 24, 1985.
For the period 1985 to 1988 , exploratory activities on the Alaska OCS focused on the Beaufort Sea. Work progressed on the Harvard, Mars, Corona, Hammerhead, and Phoenix Prospects with a total of five wells drilled in 1986 and on the Tern and Aurora Prospects with one well drilled in 1987 and one in 1988. Two of the seven wells drilled were determined producible by MMS. A total of eight wells on the Beaufort Sea OCS have been determined producible. (See table 3-1, p. 89, for a complete listing of these wells).

Two operators have announced discoveries resulting from their exploratory efforts on the OCS of the U.S. Beaufort Sea. Shell has announced that it has drilled discovery wells from both Seal and Sandpiper Islands. Shell has indicated that its Seal Island discovery appears to be commercial. Unocal has announced that both of its Hammerhead exploratory wells, located on the OCS offshore Flaxman Island, were successful. To date, Unocal has not indicated whether the Hammerhead discovery is commercial. Neither company has begun the permitting phase of development and production activities.

Amoco received approval for its exploration plan covering the Belcher Prospect. The plan covers blocks OCS-Y 917, 918, and 926. Amoco spudded the well September 6, 1988, on lease OCS-Y 917, Block 724. The well was drilled by Beaudril's Kulluk, a semisubmersible rig designed to withstand arctic sea ice. The well was spudded on September 5, 1988, and drilling was suspended on October 17, 1988, before the objective depth was reached. The Belcher Prospect well was reentered by Amoco on August 2, 1958, and plugged and abandoned after reaching total depth on August 31, 1989.

In 1989, SWEPI drilled the first exploratory wells in the Chukchi Sea planning area. SWEPI has submitted two exploration plans for the Chukchi Sea planning area. The first plan proposes 48 wells on 11 prospects located in remote areas (greater than 50 miles off shore); the second plan proposes 13 wells on 5 nearshore 
prospects (less than 50 ) miles offshore) over the next 9 years. It should be noted that while Shell's exploration plan includes 61 wells for the Chukchi Sea Planning Area, no more than 3 wells will probably be drilled per drilling season. It is also likely that the majority of the exploration wells listed will not be drilled because many of the prospects would be uneconomic on their own. On February 17, 1989, MMS approved the plan, and SWEPI spudded the first well in the summer of 1989. More information on SWEPIS Chukchi Sea prospects follows.

\section{Klondike ? rospect}

In September 1989, SWEPI completed the first of several possible exploratory wells planned for the Chukchi Sea planning area. The Klondike Prospect on lease OCS-Y 1482, Block $2 \times 7$. is located approximately 76 miles northwes of ky Cape in 140 teet of water. (Shell. whong with partners Elf Ayuitaine and Conoco. diquired $x 1$ Chukchi Sea leases for $\$ 2 \times 5.5 \mathrm{mil}$ lion at OCS Lease Sale 109 held May 25, 19x8,. The well. ipudded on July 7, 1989 , uning the Canmar Explorer III drillship, is the first of eight exploratury wells Shell proposes (1) drill on this prospect. The well was drilled (i) a depth just below $12.0(0)$ feet, and was plugged arad abandoned on September 14 , lyxy.

\section{Burger Prospect}

Shell Burger Prospect is licated approximately 5 () mile, northeast of its Klondike Prospect. in approximately 145 feet of water. The firnt of nine possible exploratory welis to be drilled on this prospect was spudded on September 22. 19xy. on lease OCS-Y 1413. Block $71 x$, using the Carmar Explorer $I / I$ drillship. The wall was emporarily abundoned on October $1+$ lyxy. nrior ... the ice encroachment. On July 2y. Iyyol. Shell reentered the hole and

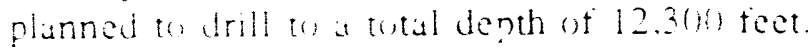
The wall was then plugged and abandoned on Aurut 22. 1yy!

\section{Popcorn Prospect}

The Popcom Prospect, located approximately 140 miles offshore Icy Cape, is the furthest offshore prospect drilled by Shell in the Chukchi Sea to date. Shell may drill a total of five wells on this prospect. The first well was spudded on October 14, 1989, on lease OCS-Y 1275, Block 150, and was temporarily abandoned on October 19, 1989, prior to ice encroachment. On July 12, 1990, Shell reentered the hole to continue drilling. After setting the surface casing, the Explorer III moved to the Burger Prospect (see previous discussion). After completing the Burger well, the drillship returned to this prospect and reentered the hole on August 23, 1990. The well was planned to be drilled to a total depth of 15,000 feet, and on September 22, 199(), the well was plugged and abandoned. Shell then moved the Explorer $I I /$ drillship to the south to start work on the Crackerjack Prospect.

\section{Crackerjack Prospect}

On September 26, 1990, Shell began work on its fourth Chukchi Sea Prospect. The Crackerjack Prospect, located approximately 20 miles south of the Popcorn Prospect, is approximately 120 miles of fshore Icy Cape. The first of nine possible exploratory wells was spudded on lease OCS-Y 1320. Block 591, in a water depth of approximately 140 fect. Shell plans to drill this well to a total depth of $15,(0)(0)$ feet. The well was temporarily abandoned on October 11, 1990, prior to ice encroachment. A series of map plates that depict offshore oil and gas activities and onshore facilities is available from the OCS Information Program. To order, contact the following office:

\footnotetext{
Document Distribution Center

Technical Communication Services

Minerals Management Service

$3 \times 1$ Elden St. MS 4530

Hendoni, VA 2207()-4ki7

Telephone: 1703) 787-1(180)
} 


\section{Other Recent Exploration Activitiy}

ARCO Alaska spudded their Fireweed Prospect OCS-Y 0267 Well No. 1 on October 19, 1990, located approximately 100 miles northwest of Prudhoe Bay and 16 miles north of Camp Lonely in approximately 50 feet of water. The well is being drilled from the CANMAR/Reading and Bates Single Steel Drilling Caisson/Mat (SSDC/Mat) which is a bottom-founded drilling structure specially designed for year-round operations in the shallow waters of the Beaufort Sea.

Texaco submitted an EP covering several Chukchi Sea Sale 109 leases and one western Beaufort Sea Sale 97 prospect. Texaco proposes to use the BeauDril Kulluk, a floating conical drilling unit, to drill beginning in the summer of 1991. The plan was approved by the MMS on June 6, 1990, subject to receiving State of Alaska coastal zone consistency certification.

Chevron submitted two EP's in July for drilling on Beaufort Sea Sale 87 leases; one plan for their Canvasback Prospect located approximately 50 miles east-northeast of Barrow and the other for the West Maktar Prospect located approximately 50 miles east of Prudhoe Bay. Both plans call for the use of the BeauDril Kulluk with operations beginning at the Canvasback location (in 120 feet of water) during summer 1991 and at West Maktar (in 100 feet of water) as carly as August 1991, but probably not until the 1992 or 1993 summer drilling season. The MMS approved the Canvasback plan on August 23, 1990, and the West Maktar plan on August 3(), 199(), subject to receiving State consistency.

Tern Island was permanently abandoned by SWEPI during August and September 199(). The three Tern wells were permanently plugged and abandoned, and the island surface hardware and slope protection was removed. The island was left to erode by the natural environmental forces.

\section{Bowhead Whale Monitoring Program}

Bowhead monitoring by the Enironmental Studies Unit, Alaska OCS Region, MMS has become an important component in mitigation of potential effects of offshore exploration, especially in determining the time and occurrence of the bowhead migration in arctic waters. The MMS has funded bowhead whale surveys in the Beaufort and Chukchi Seas since 1978. As approved by the MMS Associate Director, Alaska OCS Regional staff have assumed responsibility for conducting acrial surveys and monitoring of the bowhead whale migration in the Beaufort Sea since 1987.

The present goals of the ongoing program of endangered whale surveys and monitoring follow:

- Provide real-time data to MMS and the National Marine Fisheries Service (NMFS) on the fall migration of bowhead whales for use in implementing overall scasonal drilling restrictions and scasonal limitations on geological/geophysical expioration;

- Provide real-time site-specific data on endangered whales for use by the Regional Supervisor, Resource Evaluation, Alaska OCS Region, MMS, in day-to-day regulation of seismic-exploration operations;

- Continue collection of data to describe temporal and spatial trends in the distribution, relative abundance, habitat, and behavior of endangered whales in arctic waters;

- Continue data collection and betweenyear trend analysis of the median depth (or distance from shore) of the migration axis for bowhead whales;

- Record and map nonendangered marine mammals observed incidental to endangered whale surveys; and 
- Determine seasonal distribution of endangered whales in other planning areas of interest to MMS.

\section{Atlantic OCS Region}

Excluding the Straits of Florida Planning Area, there have been 49 exploratory wells drilled in the Atlantic OCS Region. Figure 3-6 (right) displays the number of wells drilled in the Atlantic OCS Region, by planning area and year. As the chart indicates, 65 percent of the wells were drilled in the Mid-Atlantic Planning Area, and 57 percent were spudded in 1978 and 1979. The last Atlantic exploratory well was plugged and abandoned in November 1984. Table 3-2 (p. 98) lists the exploratory wells drilled in the Atlantic OCS Region by planning area and lease sale. Figure 3-7 (p. 99 ) presents the 10cation of each of the official protraction diagrams for the Atlantic OCS Region. Each of these OPD's may be ordered from the following office:

\section{Allantic OCS Region}

Minerals Management Service

$3 \times 1$ Elden St., MS 61(0)

Herndon, VA 2207()-4817

Telephone: (703) 787-1118 or (FTS) 393-1118

The Florida Straits exploration leases were obtained from OCS Sale 5 in 1959, in which 23 blocks south of the Florida Keys were leased. Three wells were drilled by Gulf and Chevron in 1960) and 1961 between Dry Tortugas and Marquesas key. One well encountered oil shows.

Eight exploratory wells were drilled by five offshore operators within the Georges Bank Basin in the North Atlantic Planning Area between July 1981 and September 1982. The drilling sites ranged from 110 to 150 miles southeast of Nantucket Island, off the coast of Massachusetts. All eight wells were dry and were plugged and abandoned.

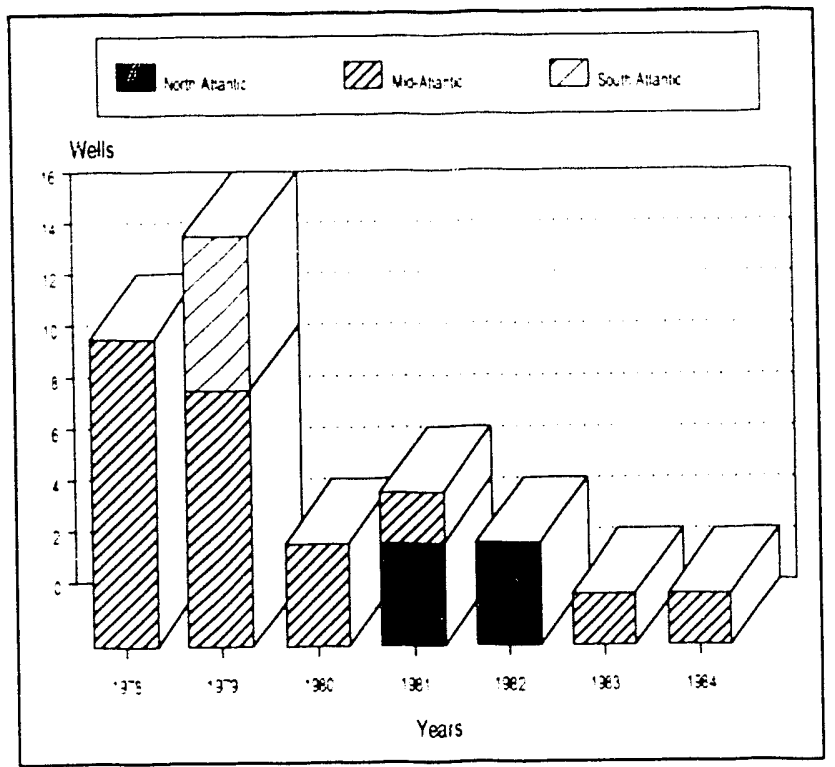

Figure 3-6. Exploratory wells drilled in the Atlantic OCS Region by planning area, January 1, 1978-October 31, 1990.

Exploratory drilling in the Mid-Atlantic Planning Area began on March 29, 1978, when Exxon drilled the first Atlantic OCS exploratory well in the Baltimore Canyon Trough. Since then, a total of 32 exploratory wells have been drilled by 9 offshore operators. Five wells, drilled on a single large structure (the Texaco-Tenneco Block 598-642 Unit), produced flows of gas and a small quantity of oil. However, the discovery was subeconomic owing to distance from shore and lack of production infrastructure. The most recent drilling, by Shell Offshore in 1983 and 1984, tested the ancient buried reef trend. Good carbonate rescrvoirs were found, but no hydrocarbons. All 32 wells have been plugged and abandoned.

Since 1979, six exploratory wells have been drilled by four offshore operators in the South Atlantic Planning Area. All of these wells were located in the Southeast Georgia Embayment. There were no commercial hydrocarbon discoveries, and the last well was plugged and abandoned on February 12, 198(). No exploratory wells have been drilled on the Atlantic OCS since 1984. 
Table 3-2. Exploratory wells drilled in the Atlantic OCS Region by planning area and lease sale

\begin{tabular}{|c|c|c|c|c|c|c|c|c|c|c|c|}
\hline $\begin{array}{l}\text { Lease } \\
\text { no. }\end{array}$ & $\begin{array}{l}\text { Block } \\
\text { no. }\end{array}$ & $\begin{array}{l}\text { OPD } \\
\text { no. }\end{array}$ & Status $^{1}$ & Operator & $\begin{array}{c}\text { POE } \\
\text { approval } \\
\text { date }\end{array}$ & Well no. & $\begin{array}{l}\text { APD } \\
\text { date }\end{array}$ & $\begin{array}{l}\text { Spud } \\
\text { date }\end{array}$ & $\begin{array}{l}\text { Comple- } \\
\text { tion } \\
\text { date }\end{array}$ & $\begin{array}{c}\text { Depth } \\
\text { drilled } \\
\text { (ft) }\end{array}$ & $\begin{array}{l}\text { Well } \\
\text { report } \\
\text { no. }\end{array}$ \\
\hline \multicolumn{12}{|c|}{ NORTH ATLANTIC } \\
\hline $\begin{array}{l}170 \\
218 \\
153 \\
200 \\
182 \\
210 \\
179 \\
196 \\
\end{array}$ & $\begin{array}{l}133 \\
410 \\
975 \\
312 \\
187 \\
357 \\
145 \\
273\end{array}$ & $\begin{array}{l}\text { NK } 19-12 \\
\text { NK } 19-12 \\
\text { NK } 19-9 \\
\text { NK } 19-12 \\
\text { NK } 19-12 \\
\text { NK } 19-12 \\
\text { NK } 19-12 \\
\text { NK } 19-12 \\
\end{array}$ & $\begin{array}{l}\mathrm{R} \\
\mathrm{R} \\
\mathrm{R} \\
\mathrm{R} \\
\mathrm{n} \\
\mathrm{B}\end{array}$ & $\begin{array}{l}\text { Exxon } \\
\text { Shell } \\
\text { Exxon } \\
\text { Mobil } \\
\text { Tenneco } \\
\text { Shell } \\
\text { Conoco } \\
\text { Mobil } \\
\end{array}$ & $\begin{array}{l}01-1581 \\
08-11-81 \\
08-12-81 \\
02-08-81 \\
08-1081 \\
08-26-81 \\
11-2781 \\
06-11-81\end{array}$ & $\begin{array}{l}133-1 \\
410-1 \\
975-1 \\
312-1 \\
187-1 \\
357-1 \\
145-1 \\
273-1 \\
\end{array}$ & $\begin{array}{l}01-12-81 \\
05-10-81 \\
09-02-81 \\
10-27-81 \\
06-08-81 \\
112781 \\
04-05-81 \\
03-26-82\end{array}$ & $\begin{array}{l}07-24-81 \\
08-10-81 \\
11-25-81 \\
12-08-81 \\
03-12-82 \\
04-14-82 \\
05-17-82 \\
06-30-82\end{array}$ & $\begin{array}{l}11-24-81 \\
03-31-82 \\
03-10-82 \\
06-27-82 \\
08-21-82 \\
09-27-82 \\
08-25-82 \\
09-13-82\end{array}$ & $\begin{array}{l}14,118 \\
15,568 \\
14,605 \\
20,000 \\
18,127 \\
19,427 \\
14,500 \\
15580 \\
\end{array}$ & $89-0007$ \\
\hline \multicolumn{12}{|c|}{ MID-ATLANTIC } \\
\hline 46 & 684 & $\mathrm{NJ} 18-3$ & $\mathbf{A}$ & Exxon & 060179 & $684-1$ & 0124.77 & $03-28 \div 8$ & $12-23-78$ & 17,620 & \\
\hline 28 & 598 & NJ $18-3$ & $\mathrm{n}$ & Texaco & 11,0077 & $598-1$ & $05-19-77$ & $04-16-78$ & $08-26-78$ & 15,025 & \\
\hline 24 & 590 & NJ 18-3 & $\mathrm{R}$ & Conoco & $12-21-77$ & $590-1$ & $02-27-77$ & $04-17-78$ & $06-07-78$ & 12,000 & \\
\hline 32 & 632 & NJ 18-3 & 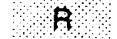 & Shell & $12-21-77$ & $632-1$ & $0922-77$ & $04-24-78$ & $07-14-78$ & 14,000 & \\
\hline 42 & 676 & NJ 18-3 & $\mathrm{R}$ & Houston Oil & $12-21-78$ & $676-1$ & 1200678 & $06-02-78$ & $09-22-78$ & 12,500 & \\
\hline 59 & 857 & NJ $18-3$ & $E$ & Gulf & 1100877 & $857-1$ & $07-26.77$ & $06-10-78$ & $01-29-78$ & 18,554 & \\
\hline 15 & 544 & NJ 18-3 & $E$ & Mobil & 11.0077 & $544-1$ & $02-15-77$ & $06-23-78$ & $12-29-78$ & 17,449 & \\
\hline 97 & 273 & NJ $18-6$ & $A$ & Shell & 1100,77 & $273-1$ & $05-18-77$ & $07-15-78$ & $12-16-78$ & 17,500 & \\
\hline 28 & 588 & NJ $18-3$ & n & Texaco & $1100-77$ & $598-2$ & $0828-78$ & $09-03-78$ & $03-20-79$ & 17,708 & \\
\hline 57 & 855 & NJ $18-3$ & $\mathrm{n}$ & Houston Oil & $09-0878$ & $855-1$ & 042478 & $09-24-78$ & 28.79 & 505 & \\
\hline 65 & 902 & NJ $18-3$ & $\mathrm{~A}$ & Exxon & $0420-78$ & $902-1$ & $12-27-77$ & $11-01-78$ & $04-15-79$ & 15,968 & \\
\hline 96 & 272 & NJ $18-6$ & $\mathrm{~F}$ & Sheil & 1100277 & $272-1$ & 0.78 & $12-30-78$ & $19-79$ & 13,500 & \\
\hline 46 & 684 & NJ 18-3 & 1 & Exxon & $11-0017$ & $684-2$ & $3-78$ & $01-05-79$ & $07-15-79$ & 16,800 & \\
\hline 75 & 17 & NJ $18-6$ & $\mathrm{E}$ & Mobil & $12+14-78$ & $17-1$ & $3-78$ & $01-06-79$ & $24-79$ & 1,200 & \\
\hline 48 & 718 & NJ $18-3$ & n & Gulf & $11108-77$ & $718-1$ & $6-77$ & $01-19-79$ & $31-79$ & 12,813 & \\
\hline 38 & 642 & NJ $18-3$ & $\mathrm{~A}$ & Tenneco & $12-10-78$ & $642-2$ & $11-15-78$ & $01-20-79$ & $08-10-79$ & 18,400 & $86-077$ \\
\hline 75 & 17 & NJ $18-6$ & $E$ & Mobil & $12-14-76$ & $17-2$ & $9-79$ & $01-26-79$ & $05-14-79$ & 13,992 & \\
\hline 38 & 642 & NJ $18-3$ & $\mathrm{~A}$ & Texaco & $12-10-78$ & $642-$ & $11-22-78$ & $03-23-79$ & $12-01-79$ & 17,807 & 89,027 \\
\hline 131 & 495 & NJ $18-6$ & $\mathrm{R}$ & Tenneco & $06-12-78$ & $495-1$ & $0509-79$ & $06-12-79$ & $1-79$ & 18,300 & \\
\hline 9 & 500 & NJ $18-3$ & $\mathrm{~A}$ & Exxon & $03-22-78$ & $500-1$ & $0-76$ & $07-18-79$ & $09-28-79$ & 12,253 & \\
\hline 28 & 598 & NJ $18-3$ & A & Texaco & $1109-77$ & $598-3$ & $10.09-79$ & $12-04-79$ & $05-25-80$ & 16,103 & $86-0129$ \\
\hline 29 & 598 & NJ $18-3$ & $\mathbf{R}$ & Exxon & $0601-79$ & $599-1$ & $03-24-80$ & $5-80$ & $11-02-80$ & 17,121 & \\
\hline 38 & 642 & NJ $18-3$ & $\mathrm{R}$ & Tenneco & $12-19-78$ & $642-3$ & $02-12-80$ & $27-80$ & $14-60$ & 16,475 & \\
\hline 81 & 108 & NJ $18-6$ & $E$ & Murphy & $1002-79$ & $106-1$ & $10-29-78$ & $12-27-79$ & $05-29-80$ & 18,405 & 88.0117 \\
\hline 28 & 598 & NJ $18-3$ & R & Texaco & 1190277 & $598-4$ & $07 / 1,80$ & $10-21-80$ & $24-81$ & 16,050 & \\
\hline 55 & 816 & NJ $18-3$ & R & Exxon & $08-10.70$ & $816-1$ & & $11-04-80$ & $05-07-81$ & 17,753 & \\
\hline 52 & 728 & NJ $18-3$ & A & Exxon & $0601-70$ & $728-1$ & $01-21-81$ & $05-09-81$ & $07-04-81$ & 15,205 & \\
\hline 15 & 544 & NJ $18-3$ & $E$ & Mobil & 0528,81 & $544-2$ & $0806-83$ & $08-28-81$ & $10-01-81$ & 8,312 & \\
\hline 337 & 557 & NJ $18-6$ & $\mathrm{~A}$ & Shell & $01-28-83$ & $587-1$ & $05-06-83$ & $08-02-83$ & & 14,500 & $87-0074$ \\
\hline 336 & 588 & NJ $18-6$ & $\mathrm{R}$ & Shell & $07-22-83$ & $586-1$ & $10-20-83$ & $12-30-83$ & $05-29-84$ & 00 & $86-0098$ \\
\hline 317 & 372 & NJ $18-6$ & $\mathrm{R}$ & Shell & $07-22-83$ & $372-1$ & $04-18-84$ & $05-26-84$ & $07-11-84$ & 11,631 & $87-0118$ \\
\hline 370 & 88 & NJ $18-9$ & $\mathrm{R}$ & Shell & $12-02-83$ & $93-1$ & $06-22-84$ & $07-14-84$ & $11-07-84$ & 17,740 & $80-0128$ \\
\hline \multicolumn{12}{|c|}{ SOUTH ATLANTIC } \\
\hline 3686 & 208 & $\mathrm{NH} 17-5$ & A & Tenneco & $10-3078$ & 28814 & $208-1$ & $05-29-79$ & $-09-79$ & & \\
\hline 3696 & 427 & $\mathrm{NH} 17-5$ & $\mathrm{P}$ & Tenneco & $04-27+78$ & 28947 & $427-1$ & $07-13-79$ & $15-79$ & 7,4 & \\
\hline 3664 & 913 & NH $17-2$ & $\mathrm{~A}$ & Getty & $01-05-7 \theta$ & 28935 & $913-1$ & $08-17-79$ & $09-14-79$ & 7,000 & \\
\hline 3671 & 1005 & $\mathrm{NH} 17-2$ & A & Transco & $04-12-70$ & 29000 & $1005-1$ & $09-19-79$ & $12-14-79$ & 11,635 & \\
\hline 3699 & 472 & NH $17-5$ & R & Exxon & $05.03-79$ & 28979 & $472-1$ & $10-08-79$ & $11-18-79$ & 7,578 & \\
\hline 3705 & 584 & NH 17-5 & $E$ & Exxon & $0921-79$ & $564-1$ & $08-20-78$ & $11-19-79$ & $02-12-80$ & 12,863 & \\
\hline \multicolumn{12}{|c|}{ STRAITS OF FLORIDA } \\
\hline & .44 & $N G-17-10$ & R & & & $44-1$ & $10-11$ & $2-60$ & $03-14-61$ & 4,686 & \\
\hline & -46 & NG-17-10 & $\mathrm{R}$ & Gulf-Chevron & & $46-1$ & $05-02-60$ & $07-31-60$ & $09-26-61$ & 7,871 & \\
\hline & 28 & $N G-17-10$ & $R$ & Gulf-Chevron & & $28-1$ & $01-12-60$ & $01-16-60$ & $05-24-60$ & 15,294 & \\
\hline
\end{tabular}

\footnotetext{
"These numbers do not represent actual block numbers as used in OPD's today;

the numbers were included as part of the sale areas' name designations.

${ }^{1} R=$ Relinquished; $E=$ Expired
} 


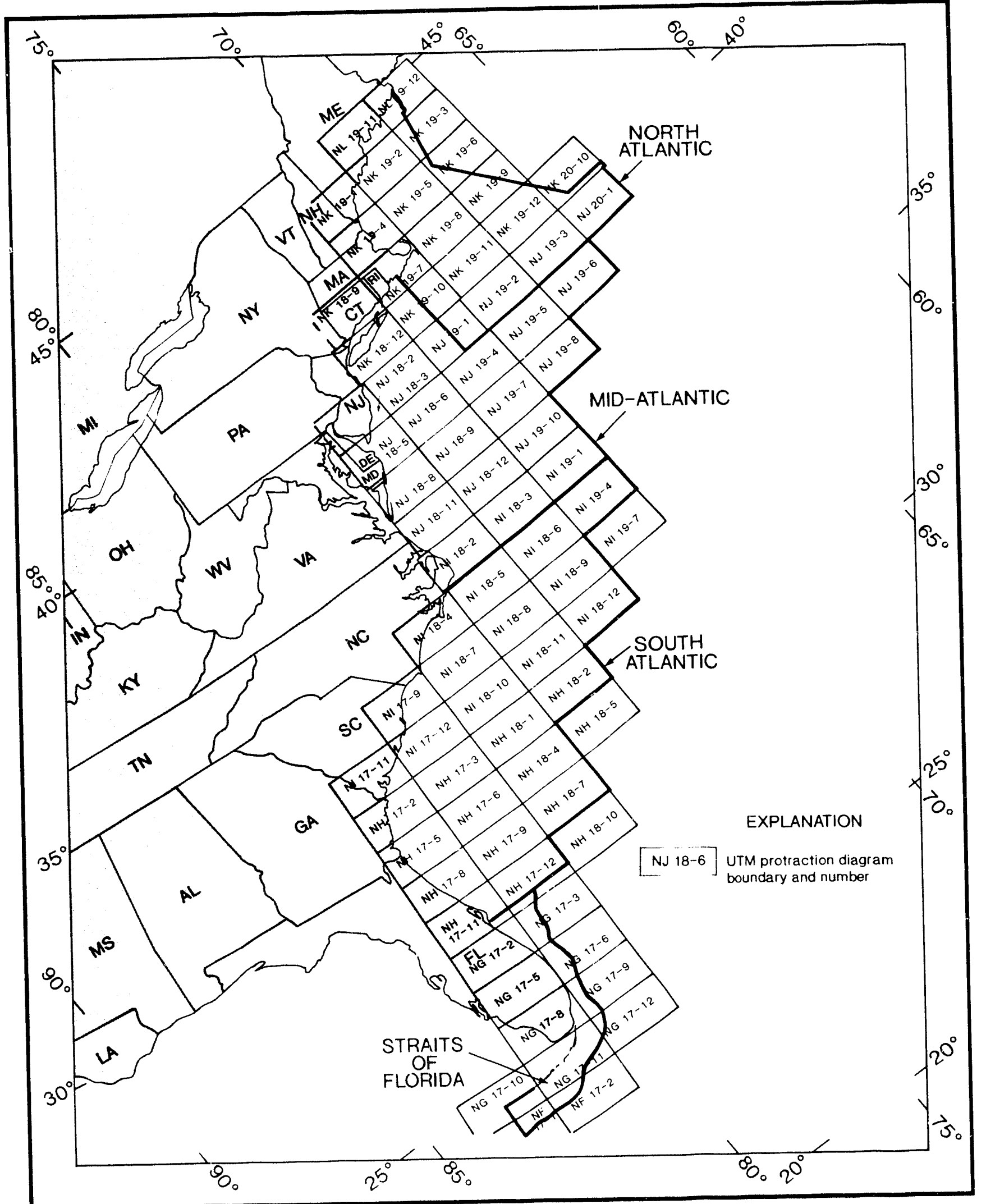

Figure 3-7. Atlantic OCS Region official protraction diagram locations. 


\section{Mobil Oil Company Manteo Exploration Well Offshore North Carolina}

On October 25, 1988, Mobil Oil Exploration \& Producing Southeast, Inc. (Mobil) announced its intention to file an exploration plan early in 1989 for drilling on Block 467 of the Manteo Prospect, which is 47 miles $(75.4 \mathrm{~km})$ off Cape Hatteras, North Carolina. The actual drilling date was anticipated to be in the spring or early summer of 1990 , but as of October 30, 1990, approval to drill the well has not been granted.

On July 12, 1989, a Memorandum of Understanding (MOU) was signed by Mobil, MMS, and the State of North Carolina. The MOU included an outline of the Environmental Report that the MMS would prepare and the timeline to be followed in reviewing the exploration plan. From August 8 to August 11, 1989, MMS conducted a series of seven public workshops and meetings in four North Carolina locations in order to identify the significant issues and areas of concern to be evaluated in the environmental report.

On September 1, 1989, Mobil filed its draft exploration plan with the MMS. The draft environmental report was issued by MMS on November 1, 1989, with a 45-day public comment period. MMS conducted eight public hearings from December 4 to December 7, 1989, in four North Carolina cities. The timeline for the project was revised at that time to more fully resolve concerns and issues on the draft document.

After working with the technical staffs of North Carolina State agencies, MMS issued a preliminary final environmental report on June 1, 1990. The State of North Carolina conducted public hearings on July 10 and July 11, 1990, in Manteo and Morehead City, North Carolina, and submitted formal comments to the MMS on July 30 , 1990 .

On August 20, 1990, Mobil submitted the final exploration plan to MMS. On August 30, 1990, MMS issued the final Environmental Report on the project. On August 30, 1990, the MMS Atlantic OCS Region determined that
Mobilss Exploration Plan (NI 18-2 Block 467) for a singie exploratory well approximately 39 miles offshore the Uuter Banks of North Carolina was "complete and submitted." The plan was distributed to various State and Federal agencies for review and comment. An Environmental Assessment was completed by the MMS on September 28, 1990, and a Finding of No Significant Impact was issued.

As of July 17, 1990, North Carolina determined the Draft NPDES (discharge) permit for Mobils proposal to be inconsistent with its approved Coastal Zone Management Program. Mobil filed an appeal of that decision with the Commerce Department on July 27, 1990, and a public hearing regarding this matter was scheduled for December 1990. The State's ruling on Mobil's consistency determination on the Exploration Plan is due November 19, 1990.

The Oil Pollution Act of 1990 (see the oil spill section in ch. 5) prohibits the MMS from approving any Exploration Plan for leases offshore North Carolina, including Mobil's Plan for Block 467. A scientific review panel is being formed to determine the aciequacy of the data base available to decisionmakers. The panel's report is due 6 months from the August 18, 1990, effective date of the Oil Pollution Act.

The OCS Information Report MMS 90-0060 Atlantic Update: July 1986-June 1990 includes a detailed section on the Mobil Manteo Prospect exploration project, including the MOU and the revised project timeline. For further information contact the following office:

Atlantic OCS Region

Minerals Management Service

381 Elden St., MS 6000)

Hemdon, VA 2207()-4817

Telephone: (7(1)3)787-1118 or (FTS)393-1118. 


\section{Gulf of Mexico OCS Region}

The search for hydrocarbons in the Gulf of Mexico has followed a natural progression from onshore sites, to coastal bays and estuaries, to the continental shelf, and recently to the upper continental slope. As of October 31 , 1990 , a total of 9.758 exploratory wells have been spudded in the Gulf of Mexico OCS Region. As shown on figure 3-8 (right), over 76 percent of these wells were drilled in the Central Gulf of Mexico Planning Area. Table 3-3 (p. 102) summarizes the number of exploratory wells drilled by planning area and year since 1954.

Offshore exploration in the Gulf of Mexico began in 1933 with the region's first attempt to drill an offshore well. This well was drilled at a site 6,00) feet of fshore in the Creole field off Louisiana by the Pure Oil Company and the Superior Oil Company. It was drilled from a small wooden platform on pilings in $13 \mathrm{fect}$ of water.

In 1947, the Kerr-McGec Oil Company, operating in the Ship Shoal Area off Terrebonne Parish, Louisiana, discovered the Gulf"s first commercial of fshore oil located completely out of sight of land. The installation consisted of a fixed platform for the rig plus basic machinery. Equipment, supplies, and crew quarters were provided by a small fleet of barges that moved between the platform and a support base at Berwick, Louisiana, 52 miles away. Following this success, the use of onshore support bases became the universal method of operation in offshore development.

Since 1947, exploration in the Gulf of Mexico OCS Region has procecded rapidly. From 1947 through the late 1970)s, exploratory activity focused on areas off the coast of Louisiand. In 1979, industry, while still actively exploring off the eorast of Louisiana, looked to other areas within the Gulf of Mexico off the coasts of Texas, Mississippi. Alabama, and Filoriclia.

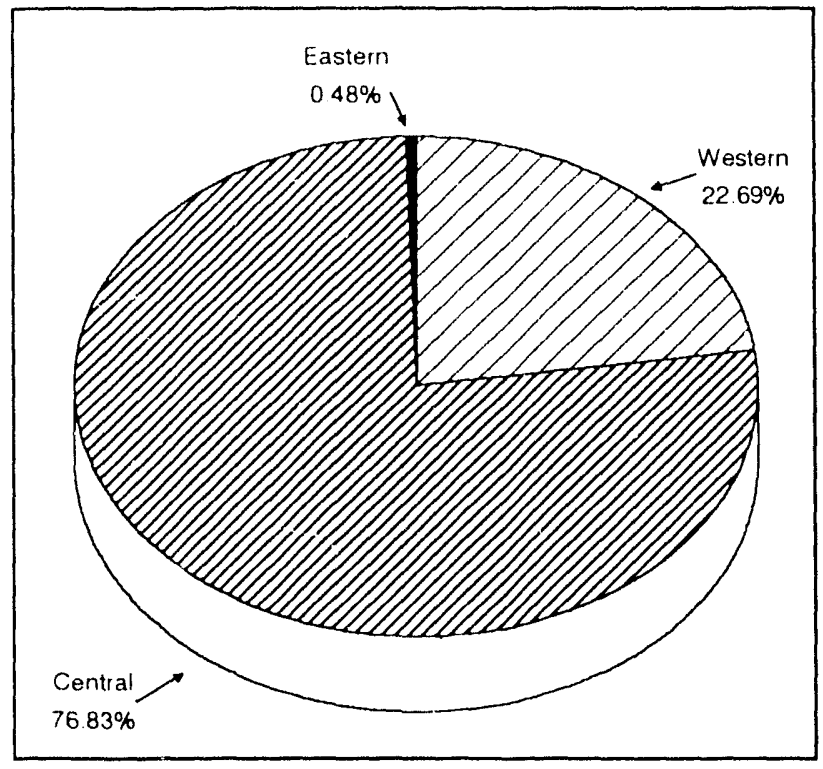

Figure 3-8. Total exploratory wells drilled in the Gulf of Mexico OCS Region by planning area and lease sale through October 31, 1990.

Most of the activity off Texas in the late 1970 's and early 1980's was in water depths less than 150 feet. This activity focused on the Sabine Pass area, on the upper Texas coastline near the Louisiana border, and on the Brazos Ridge, which runs through the south and central offshore area of Texas.

Exploratory wells were also drilled in the Destin Dome, Elbow, Vernon, Pensacola, and Charlotte Harbor areas off the coasts of Mississippi, Alabama, and Florida as industry continued to explore throughout the Gulf of Mexico in the carly 1980's. The geology of the Charlotte Harbor area differs from that of the rest of the Gulf of Mexico region. Operators hope that the Sunniland Trend, which is the productive formation in the onshore South Florida Basin, extends offshore. The same types of Cretaceous carbonates underlie both onshore and adjacent offshore areas.

With the introduction of areawide leasing in the Gulf of Mexico during 1983, offshore opcrators turned their attention to previously unexplored areas within the region. Among the 
Table 3-3. Exploratory wells drilled in the Gulf of Mexico OCS Region, by planning area, 1954-October 31, 1990

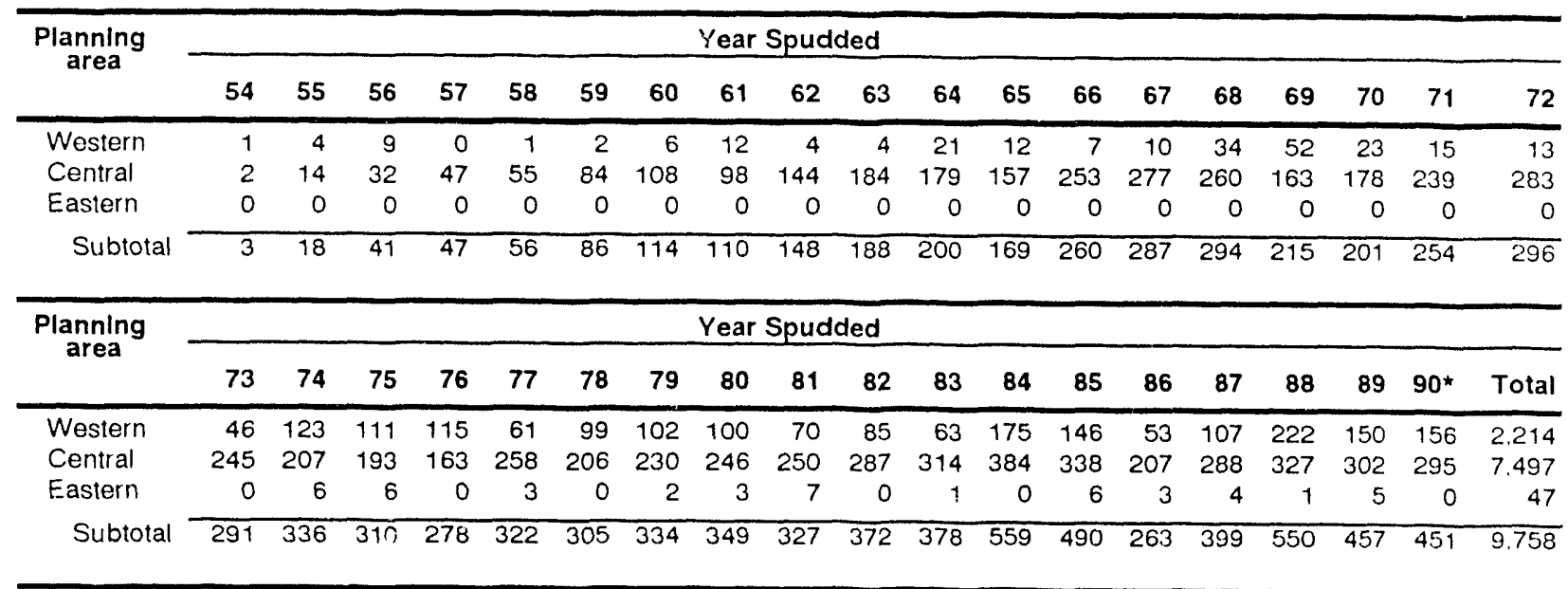

As of October 31, 1990

first areas to be considered for new exploration ventures were the deep-water areas of the Mississippi Canyon, Ewing Bank, and Green Canyon leasing areas. Industry interest in these areas stems from Shell Offshore, Inc.'s discovery along the deep-water Flexure Trend in the 1970 's. Geologists believe that this trend is an extension of formations found at the mouth of the Mississippi River.

Although oil prices declined in the late 1980 s, the deep-water areas of the central and western Gulf, the area adjacent to Mobile Bay, and portions of the cascern Gulf continued to experience high interest, as the industry scarched for large oil and gas finds in these relatively unexplored areas.

Representative of industrys interest in the deep-water areas of the Gulf of Mexico in the late 1980 's, Shell Offshore Inc. set a world drilling record when it drilled its No. I well on Mississippi Canyon Block 657. Using the Sonat drillship Discoverer Seven Seas. Shell spudded this well on November 4, 1987, in $7.521)$ feet of water. This well was later determined to be producible by MMS and, as such. ret a deep-water discovery record.
Since 1986, exploratory activities in the Eastern Gulf of Mexico OCS Planning Area have focused on areas offshore the panhandle of Florida. Plans of exploration were approved for acreage in the Destin Dome, Florida Middle Ground, and Pulley Ridge areas of the castern Gulf. A history of the exploratory wells drilled in the Eastern Gulf of Mexico Planning Area is provided in table 3-4 (p. 1(13).

In February 1988, two exploratory wells offshore Florida in the panhandle area were determined capable of producing hydrocarbons in paying quantities. Well No. 1 in Destin Dome Block 111 was drilled by Amoco; this was the first reported discovery in Federal waters in the castern Gulf of Mexico. Well No. 1 in Destin Dome Block 56 was drilled by Chevron.

An interesting trend revers al in drilling $心$ curred within the Gulf of Mexico in 1988 and 1989. Historically, 18-24 pereent of the wells drilled were exploratory in nature, but this trend began to change shortly after the first areawide lease sale was hold in 1983. An analysis of drilling trends for the past 5 years shows that 42 percent of the wells drilled were exp!eratory and 58 pereent were for development. The year 1988 brought a strong reversal of that trend. As the graph in figure $3.9 \mathrm{lp}$. 
Table 3-4. Exploratory wells drilled in the Eastern Gulf of Mexico DCS Planning Area as of October 31, 1990

\begin{tabular}{|c|c|c|c|c|c|c|c|c|}
\hline OPD & $\begin{array}{c}\text { Block } \\
\text { number }\end{array}$ & $\begin{array}{c}\text { Lease } \\
\text { number } \\
\text { (OCS-G) }\end{array}$ & Operator & $\begin{array}{c}\text { Well } \\
\text { number }\end{array}$ & $\begin{array}{l}\text { Water } \\
\text { dept } \\
\text { (ft) }\end{array}$ & $\begin{array}{l}\text { Spud } \\
\text { date }\end{array}$ & $\begin{array}{l}\text { Plugged \& } \\
\text { abandoned } \\
\text { date }\end{array}$ & $\begin{array}{l}\text { Total } \\
\text { depth } \\
\text { (ft) }\end{array}$ \\
\hline Destin Dome & 162 & 2486 & Exxon Corp. & 1 & 245 & $07 / 07 / 74$ & $09 / 03 / 74$ & 10,930 \\
\hline Destin Dome & 118 & 2492 & Exxon Corp. & 1 & 239 & $09 / 04 / 74$ & $09 / 29 / 74$ & 7,075 \\
\hline Florida Middle Ground & 252 & 2516 & Texaco, Inc. & 1 & 126 & $09 / 22 / 74$ & $01 / 26 / 75$ & 15,663 \\
\hline Destin Dome & 166 & 2490 & Fina Oil & 1 & 145 & $10 / 21 / 74$ & $03 / 09 / 75$ & 17,608 \\
\hline St. Petersburg & 7 & 2527 & Shell Oil & 1 & 126 & $10 / 24 / 74$ & $05 / 09 / 75$ & 18,443 \\
\hline Destin Dome & 162 & 2486 & Exxon Corp. & 2 & 262 & $11 / 27 / 74$ & $01 / 07 / 75$ & 10,418 \\
\hline Destin Dome & 118 & 2492 & Exiun Corp. & 2 & 232 & $01 / 08 / 75$ & $01 / 27 / 75$ & 7,507 \\
\hline St. Petersburg & 100 & 2523 & Texaco, Inc. & 1 & 107 & $01 / 27 / 75$ & $05 / 26 / 75$ & 17,388 \\
\hline Destin Dome & 250 & 2472 & Exxon Corp. & 1 & 296 & $01 / 30 / 75$ & $02 / 17 / 75$ & 6,634 \\
\hline Destin Dome & 207 & 2480 & Exxon Corp. & 1 & 280 & $02 / 18 / 75$ & $03 / 03 / 75$ & 4,800 \\
\hline Destin Dome & 162 & 2486 & Exxon Corp. & 3 & 258 & $03 / 02 / 75$ & $06 / 12 / 75$ & 17,938 \\
\hline Destin Dome & 360 & 2468 & Gult Oil Corp. & 1 & 300 & $04 / 21 / 75$ & $10 / 02 / 75$ & 20,988 \\
\hline The Elbow & 566 & 3344 & Mobil Oil E \& P & 1 & 220 & $04 / 05 / 77$ & $10 / 03 / 77$ & 15,865 \\
\hline Destin Dome & 617 & 2463 & Chevron USA, Inc. & 1 & 446 & $09 / 19 / 77$ & $10 / 15 / 77$ & 10,513 \\
\hline Destin Dome & 31 & 2502 & Amoco Production & 1 & 188 & $12 / 03 / 77$ & $12 / 14 / 77$ & 18,338 \\
\hline Destin Dome & 529 & 3888 & Shell Offshore, Inc. & 1 & 227 & $03 / 05 / 80$ & $06 / 28 / 80$ & 20,450 \\
\hline Charlotte Harbor & 144 & 3906 & Gulf Oil Corp. & 1 & 173 & $04 / 09 / 80$ & $08 / 14 / 81$ & 11,362 \\
\hline Charlotte Harbor & 672 & 3917 & Tenneco & 1 & 190 & $12 / 17 / 80$ & $04 / 08 / 81$ & 11,302 \\
\hline Charlotte Harbor & 265 & 3912 & Shell Offshore, Inc. & 1 & 324 & $01 / 02 / 81$ & $04 / 09 / 81$ & 12,362 \\
\hline The Elbow & 915 & 3341 & Mobil Oil E\& P & 1 & 370 & $01 / 03 / 81$ & $06 / 01 / 81$ & 18,128 \\
\hline Vernon Basin & 654 & 3903 & Mobil Oil E \& P & 1 & 455 & $01 / 28 / 81$ & $04 / 05 / 81$ & 10,768 \\
\hline Chailotte Harbor & 628 & 3915 & Mobil Oil E \& P & 1 & 200 & $03 / 29 / 81$ & $04 / 12 / 81$ & 1,270 \\
\hline Pensacola & 973 & 3886 & Mobil Oil E \& P & 1 & 90 & $04 / 17 / 81$ & $11 / 01 / 81$ & 23,264 \\
\hline Charlotte Harbor & 188 & 3909 & Odeco Oil \& Gas & 1 & 180 & $06 / 26 / 81$ & $09 / 04 / 81$ & 11.360 \\
\hline Destin Dome & 563 & 3890 & Sohio Petroleum & 1 & 275 & $11 / 19 / 81$ & $07 / 29 / 82$ & 21,068 \\
\hline Destin Dome & 160 & 6417 & Shell Offshore, Inc. & $1 \mathrm{TA}$ & 281 & $01 / 01 / 85$ & $05 / 02 / 85$ & 7,764 \\
\hline Pensacola & 948 & 6391 & Sohio Petroleum & 1 & 164 & $02 / 16 / 85$ & $10 / 14 / 85$ & 18,958 \\
\hline Destin Dome & 160 & 6417 & Shell Offshore, Inc. & 2 & 292 & $05 / 09 / 85$ & $08 / 16 / 85$ & 16,953 \\
\hline Gainesville & 707 & 6456 & Sohio Petroleum & 1 & 70 & $06 / 07 / 85$ & $11 / 08 / 85$ & 15,941 \\
\hline Destin Dome & 284 & 6428 & Exxon Corp. & 1 & 607 & $06 / 28 / 85$ & $11 / 15 / 85$ & 17.500 \\
\hline Destin Dome & 422 & 6438 & Chevron USA, Inc. & 1 & 591 & $07 / 01 / 85$ & $12 / 21 / 85$ & 22,222 \\
\hline De Soto Canyon & 512 & 6472 & Shell Offshore, Inc. & 1 & 1,976 & $04 / 26 / 86$ & $06 / 21 / 86$ & 12,300 \\
\hline Charlotte Harbor & 622 & 4950 & Shell Offshore, Inc. & 1 & 234 & $05 / 10 / 86$ & $06 / 21 / 86$ & 10,550 \\
\hline Florida Middle Ground & 455 & 8363 & Tenneco & 1 & 470 & $09 / 24 / 86$ & $11 / 08 / 86$ & 12,401 \\
\hline Pensacola & 948 & 6391 & Tenneco & $2 \mathrm{ST}$ & 159 & $06 / 07 / 87$ & $10 / 07 / 87$ & 19,200 \\
\hline Destin Dome & 111 & 8338 & Amoco Production & 1 & 389 & $06 / 10 / 87$ & $10 / 16 / 87$ & 19,240 \\
\hline Destin Dome & 56 & 6406 & Chevron USA, Inc. & $1 \mathrm{TA}$ & 187 & $06 / 12 / 87$ & $01 / 26 / 88$ & 22,572 \\
\hline Pensacola & 948 & 6391 & Tenneco & 2 TA & 159 & $10 / 14 / 87$ & $01 / 19 / 88$ & 19,200 \\
\hline Pensacola & 996 & 63.96 & Texaco, Inc. & 1 & 160 & $04 / 08 / 88$ & $09 / 07 / 88$ & 17,910 \\
\hline Destin Dome & 1 & 6397 & Gulfstar & $1 \mathrm{TA}$ & 105 & $01 / 09 / 89$ & $01 / 18 / 89$ & 2,000 \\
\hline Destin Dome & 2 & 6398 & Gulfstar & $2 \mathrm{TA}$ & 105 & $01 / 21 / 89$ & $01 / 27 / 89$ & 1,800 \\
\hline Pensacola & 881 & 6390 & Gulfstar & $1 \mathrm{TA}$ & 57 & $01 / 29 / 89$ & $02 / 07 / 89$ & 2.700 \\
\hline Desti, Dome & 167 & 6420 & Chevron & 1 & 133 & $03 / 22 / 89$ & $03 / 25 / 89$ & 17,259 \\
\hline Destin Dome & 56 & 6406 & Chevron & 2 & & $10 / 31 / 89$ & $03 / 25 / 89$ & \\
\hline
\end{tabular}

1(4) shows, the percentage of exploratory wells drilled began to increase steadily in 1983. In 1988 , the percentage of exploratory wells drilled passed the 5()-percent mark, accounting for over 61 percent of the wells drilled in the (iult of Mexico (Offshore, Pennwell Publishing (o). January 1989, vol. 49, no. 1, p. 2(1)-23).
This rise in exploratory activity continued into 1989 as the remainder of the 5 -year primary term leases issued during OCS areawide sales expired. Leases not drilled in accordance with a plan of exploration approved by MMS automatically expire ai the end of their primary term. Many of the shallow water, 5-ycar primary term leases from OCS Lease Sales 72 and 
74 were drilled in 1988. Leases from OCS Lease Sales 79, 81, and 84 were drilled during 1989. As the graph in figure 3-10 (below) shows, exploratory drilling in 1988 reached a record high of 55() wells in the Gulf of Mexico.

As discussed above, exploratory drilling in 1988 and 1989 focused on the shallow water leases that were due to expire in 1988 and 1989. However, some of the decp-water areas of the Gulf continued to be explored. Deepwater exploration continued to focus on the Flexure trend off Louisiana and Texas in the Westem and Central Gulf of Mexico. Plans of exploration submitted recently by a number of oil companies identified wells in water depths from 1,000 feet in Green Canyon Block 26 to over 6,90() feet in Mississippi Canyon Block 522. This trend to decper waters in the Gulf of Mexico is expected to continue through 1990 as well. Table $3-5$ (p. $105 \& 106$ ) provides more information on recent deep-water drilling activity.

Exploration on a salt and sulphur lease, which was issued in 1988 as a result of the first salt and sulphur lease sale since 1969 , led to a number of discoveries off the mouth of the Mississippi River. Freeport-McMoRan Resource Partners, which owns 62 percent of the lease, announced in January 1989 that they have "possibly discovered one of the largest Frasch (see sidebar below for definition) sulphur reserves in North America." The discoveries are located in the Central Gulf of Mexico Planning Area on Main Pass Block 299, located 20 miles east of the mouth of the Mississippi River. The company said that they have completed exploratory work on the lease and plan to start production in 1992 (Jay Handleman, Freeport-McMoRan, oral communication, September 199()).

\section{Frasch Process}

Herman Frasch, a Canadian chemist, developed a process for mining native sulphur, in which superheated water is forced into the deposits for the purpose of rielting the sulphur. The molten sulphur is then pumped to the surface.

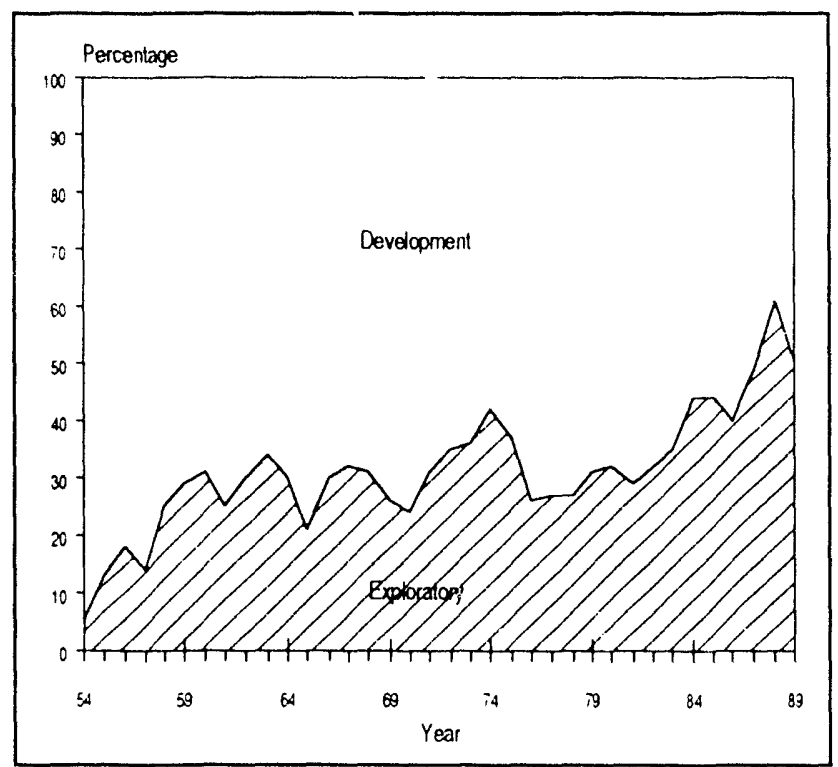

Figure 3-9. Percentage of exploratory wells drilled, by year, in the Gulf of Mexico OCS Region, 1954-89.

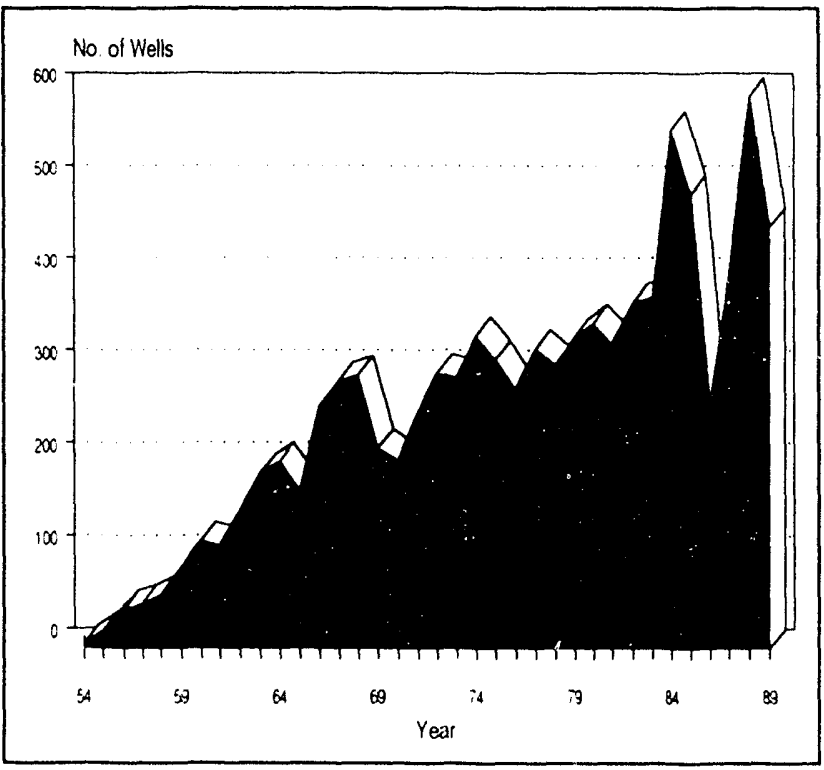

Figure 3-10. Exploratory wells drilled in the Gulf of Mexico OCS Region, 1954--89. 
Table 3-5. Deep-water drilling activity in the Gulf of Mexico OCS Region, January 1, 1989-October 31, 1990

\begin{tabular}{|c|c|c|c|c|c|c|c|c|c|}
\hline $\begin{array}{c}\text { Adminlstrative } \\
\text { area }\end{array}$ & $\begin{array}{c}\text { Block } \\
\text { number }\end{array}$ & $\begin{array}{c}\text { Lease } \\
\text { number } \\
\text { (OCS-G) }\end{array}$ & Operator & $\begin{array}{c}\text { Well } \\
\text { number }\end{array}$ & $\begin{array}{l}\text { Well } \\
\text { type }\end{array}$ & $\begin{array}{l}\text { Spud } \\
\text { date }\end{array}$ & & $\begin{array}{l}\text { Plugged and } \\
\text { abandoned } \\
\text { date }\end{array}$ & $\begin{array}{c}\text { Water } \\
\text { depth } \\
(\mathrm{ft})\end{array}$ \\
\hline \multirow[t]{2}{*}{ East Breaks } & 600 & 6322 & Exxon & 1 & $E$ & $03 / 25 / 89$ & & $04 / 29 / 89$ & 2,976 \\
\hline & 384 & 9171 & Shell Offshore & 1 & $E$ & $11 / 04 / 89$ & & $12 / 10 / 89$ & 2,110 \\
\hline \multirow[t]{2}{*}{ Ewing Bank } & 966 & 6925 & Oryx Energy & 3 & $\bar{E}$ & $05 / 27 / 89$ & & $06 / 01 / 89$ & 1,766 \\
\hline & 966 & 6925 & Oryx Energy & 4 & $E$ & $06 / 17 / 89$ & & $07 / 30 / 89$ & 1,766 \\
\hline \multirow[t]{11}{*}{ Garden Banks } & 378 & 8229 & Conoco & 1 & $\bar{E}$ & $07 / 05 / 89$ & & $11 / 21 / 89$ & 1,840 \\
\hline & 300 & 7472 & Elf Exploration & 1 & $E$ & $09 / 16 / 89$ & & $10 / 29 / 89$ & 1,550 \\
\hline & 343 & 7476 & Amoco Prod. & 1 & $E$ & $10 / 05 / 89$ & & $11 / 02 / 89$ & 1,719 \\
\hline & 594 & 11548 & Shell Offshore & 1 & $E$ & $12 / 22 / 89$ & & $03 / 04 / 90$ & 2,560 \\
\hline & 388 & 7486 & Exxon & 2 & $E$ & $01 / 27 / 90$ & $\because A$ & $04 / 07 / 90$ & 2,304 \\
\hline & 387 & 7485 & Exxon & 1 & $E$ & $04 / 22 / 90$ & & $07 / 04 / 90$ & 2,376 \\
\hline & 425 & 8241 & Shell Offshore & A001 & $E$ & $05 / 06 / 90$ & $T \lambda$ & $07 / 21 / 90$ & 2,861 \\
\hline & 426 & 8241 & Shell Otfshore & $\mathrm{AOO2}$ & $E$ & $05 / 08 / 90$ & & DRL & 2,860 \\
\hline & 426 & 8241 & Shell Offshore & $\mathrm{A} 003$ & $E$ & $08 / 04 / 90$ & & DRL & 2,861 \\
\hline & 426 & 8241 & Shell Offshore & $\mathrm{A} 004$ & $E$ & $08 / 05 / 90$ & & DRL & 2,861 \\
\hline & 302 & 9223 & Conoco & 1 & $E$ & $09 / 30 / 90$ & & DRL & 2,435 \\
\hline \multirow[t]{39}{*}{ Green Canyon } & 162 & 7025 & Oryx Energy & 1 & $\bar{E}$ & $05 / 05 / 8,3$ & $\overline{T A}$ & $07 / 11 / 89$ & 2,616 \\
\hline & 27 & 6992 & AGIP Petro. & 1 & $E$ & $05 / 2=/ 89$ & $T A$ & $06 / 05 / 89$ & 1,593 \\
\hline & 65 & 5900 & Shell Offshore & A031 & $D$ & $05 /: 25 / 89$ & DSI & $07 / 02 / 89$ & 1,353 \\
\hline & 166 & 7028 & Exxon & 2 & $E$ & 05/21ים & $T A$ & $10 / 31 / 89$ & 2,315 \\
\hline & 228 & 5912 & Conoco & 5 & $E$ & $06 / 02 / 8: 3$ & ST & $07 / 14 / 89$ & 1,588 \\
\hline & 65 & 5900 & Shell Offshore & $\mathrm{A} 032$ & D & $07 / 14 / 8^{\prime} 3$ & DSI & $10 / 29 / 89$ & 1,353 \\
\hline & 65 & 5900 & Shell Offshore & $\mathrm{A} 033$ & $D$ & $07 / 24,89$ & DSI & 08/30/89 & 1,353 \\
\hline & 228 & 5912 & Conoco & 5 & $E$ & $07 / 24 / 89$ & & $08 / 13 / 89$ & 1,588 \\
\hline & 197 & 11031 & Shell Offshore & 1 & $E$ & $09 / 07 / 89$ & & $10 / 22 / 89$ & 2,100 \\
\hline & 65 & 5900 & Shell Offshore & A005 & $D$ & $10 / 02 / 89$ & COM & $12 / 02 / 89$ & 1,353 \\
\hline & 65 & 5900 & Shell Offshore & $\mathrm{A} 034$ & $D$ & $11 / 06 / 89$ & DSI & $12 / 07 / 89$ & 1,353 \\
\hline & 71 & 11018 & Shell Offshore & 1 & $E$ & $11 / 27 / 89$ & & $12 / 21 / 89$ & 1,860 \\
\hline & 65 & 5900 & Shell Offshore & $A 035$ & $\bar{D}$ & $12 / 15 / 89$ & DSI & $01 / 14 / 90$ & 1,353 \\
\hline & 162 & 7025 & Oryx Energy & 2 & $E$ & $01 / 16 / 90$ & & $04 / 10 / 90$ & 2,580 \\
\hline & 65 & 5889 & Shell Offshore & A006 & $\mathrm{D}$ & $01 / 17 / 90$ & DSI & $01 / 19 / 90$ & 1,353 \\
\hline & 65 & 5900 & Shell Offshore & A036 & D & $01 / 20 / 90$ & DSI & $02 / 18 / 90$ & 1,353 \\
\hline & 908 & 11096 & Shell Offshore & 1 & $E$ & $01 / 27 / 90$ & & $01 / 29 / 90$ & 5,630 \\
\hline & 908 & 11096 & Shell Offshore & 2 & $\bar{E}$ & $02 / 06 / 90$ & & $04 / 20 / 90$ & 5,678 \\
\hline & 65 & 5889 & Shell Offshore & A060 & $\bar{D}$ & $02 / 09 / 90$ & COM & $03 / 01 / 90$ & 1,353 \\
\hline & 160 & 7996 & BP Exploration & 1 & $E$ & $02 / 13 / 90$ & TA & $05 / 13 / 90$ & 2,500 \\
\hline & 65 & 5900 & Shell Offshore & A037 & $\mathrm{D}$ & $02 / 24 / 90$ & DSI & $03 / 19 / 90$ & 1,353 \\
\hline & 65 & 5889 & Shell Offshore & $A 007$ & $D$ & $03 / 18 / 90$ & & $03 / 20 / 90$ & 1,353 \\
\hline & 65 & 5889 & Shell Offshore & $A 038$ & $D$ & $03 / 23 / 3 n$ & DSI & $04 / 14 / 90$ & 1,353 \\
\hline & 65 & 5889 & Shell Offshore & A059 & $D$ & $03 / 28 / 90$ & DSI & $10 / 01 / 90$ & 1,353 \\
\hline & 65 & 5900 & Shell Offshore & A039 & $D$ & $04 / 18 / 90$ & DSI & $05 / 13 / 90$ & 1,353 \\
\hline & 65 & 7005 & Shell Otfshore & $\mathrm{A} 040$ & $D$ & $05 / 20 / 90$ & DSI & $07 / 10 / 90$ & 1,353 \\
\hline & 65 & 5889 & Shell Offshore & $A 008$ & $D$ & $06 / 05 / 90$ & DSI & $07 / 29 / 90$ & 1,353 \\
\hline & 227 & 8001 & Conoco & 1 & $E$ & $06 / 30 / 90$ & & $09 / 17 / 90$ & 1,813 \\
\hline & 65 & 5900 & Shell Offshore & $A 041$ & $D$ & $07 / 15 / 90$ & DSI & $08 / 06 / 90$ & 1,353 \\
\hline & 65 & 5900 & Shell Offshore & $\mathrm{A} 042$ & $D$ & $08 / 11 / 90$ & ST & $09 / 30 / 90$ & 1,353 \\
\hline & 161 & 5909 & Chevron & 1 & $E$ & $08 / 27 / 90$ & ST & $09 / 06 / 90$ & 2,575 \\
\hline & 65 & 5900 & Shell Oftshore & $\mathrm{A} 042$ & $D$ & $10 / 06 / 90$ & DSI & & 1,353 \\
\hline & 65 & 5889 & Shell Ottshore & $A 009$ & $D$ & $10 / 12 / 90$ & DSI & & 1,353 \\
\hline & 260 & 11045 & BP Exploration & 1 & $E$ & $10 / 18 / 90$ & & DRL & 3,730 \\
\hline & 65 & 5889 & Shell Offshore & $\mathrm{A} 043$ & D & $10 / 26 / 90$ & & DRL & 1,353 \\
\hline & 161 & 5909 & Chevron & 1 & $E$ & $10 / 30 / 90$ & ST & $11 / 01 / 90$ & 2,575 \\
\hline & 65 & 5900 & Shell Offshore & $A 010$ & $D$ & $11 / 09 / 90$ & & DRL & 1,353 \\
\hline & 161 & 5909 & Chevron & 1 & $E$ & $11 / 13 / 90$ & & DRL & 2,575 \\
\hline & 228 & 5912 & Conoco & 6 & $E$ & $11 / 16 / 90$ & & DRL & 1.650 \\
\hline
\end{tabular}


Table 3-5. Deep-water drilling activity in the Gulf of Mexico OCS Region, January 1, 1989-October 31, 1990-continued

\begin{tabular}{|c|c|c|c|c|c|c|c|c|c|}
\hline $\begin{array}{c}\text { Adminlstratlve } \\
\text { area }\end{array}$ & $\begin{array}{l}\text { Block } \\
\text { number }\end{array}$ & $\begin{array}{c}\text { Lease } \\
\text { number } \\
\text { (OCS-G) }\end{array}$ & Operator & $\begin{array}{c}\text { Well } \\
\text { number }\end{array}$ & $\begin{array}{l}\text { Well } \\
\text { type }\end{array}$ & $\begin{array}{l}\text { Spud } \\
\text { date }\end{array}$ & & $\begin{array}{l}\text { Plugged and } \\
\text { abandoned } \\
\text { date }\end{array}$ & $\begin{array}{c}\text { Water } \\
\text { depth } \\
\text { (ft) }\end{array}$ \\
\hline \multirow[t]{30}{*}{ Mississippi Canyon } & 28 & 9771 & BP Exploration & 2 & $E$ & $06 / 09 / 89$ & $T A$ & $07 / 14 / 89$ & 1,830 \\
\hline & 546 & 6965 & Amoco Prod. & 2 & $E$ & $06 / 22 / 89$ & ST & $06 / 30 / 89$ & 2,500 \\
\hline & 401 & 5845 & Oryx Energy & 3 & $E$ & 07/07/89 & ST & $07 / 30 / 89$ & 1,372 \\
\hline & 807 & 7963 & Shell Offshore & 1 & $E$ & $07 / 26 / 89$ & ST & $11 / 30 / 89$ & 3,013 \\
\hline & 401 & 5845 & Oryx Energy & 3 & $E$ & $08 / 04 / 89$ & ST & $08 / 08 / 89$ & 1,372 \\
\hline & 401 & 5844 & Oryx Energy & 3 & $E$ & $08 / 09 / 89$ & ST & $09 / 05 / 89$ & 1,372 \\
\hline & 546 & 6965 & Amoco Prod. & 2 & $E$ & $09 / 06 / 89$ & & $09 / 10 / 89$ & 2,501 \\
\hline & 401 & 5845 & Oryx Energy & 3 & $E$ & $09 / 22 / 89$ & & $09 / 28 / 89$ & 1,372 \\
\hline & 28 & 9771 & BP Exploration & 3 & $E$ & $10 / 04 / 89$ & & $11 / 27 / 89$ & 1,494 \\
\hline & 118 & 7925 & ARCO & 1 & $E$ & $11 / 18 / 89$ & ST & $12 / 06 / 89$ & 2,782 \\
\hline & 28 & 9771 & BP Exploration & 3 & $E$ & $11 / 29 / 89$ & & $12 / 16 / 89$ & 1,494 \\
\hline & 118 & 7925 & ARCO & 1 & $E$ & $12 / 10 / 89$ & & $01 / 04 / 90$ & 2,782 \\
\hline & 807 & 7963 & Shell Offshore & 1 & $E$ & $12 / 13 / 89$ & & $01 / 11 / 90$ & 3,013 \\
\hline & 441 & 5080 & EP Operating & 3 & $E$ & $02 / 01 / 90$ & & $02 / 05 / 90$ & 1,438 \\
\hline & 211 & 8803 & Exxon Corp. & 1 & $E$ & $02 / 08 / 90$ & & $05 / 25 / 90$ & 4,356 \\
\hline & 72 & 8483 & BP Exploration & 1 & $E$ & $02 / 17 / 90$ & & $03 / 17 / 90$ & 1,978 \\
\hline & 441 & 5080 & EP Operating & 4 & $E$ & $02 / 25 / 90$ & ST & $03 / 02 / 90$ & 1,427 \\
\hline & 807 & 7963 & Shell Offshore & 2 & $E$ & $03 / 14 / 90$ & & $04 / 02 / 90$ & 2,925 \\
\hline & 441 & 5080 & EP Operating & 4 & $E$ & $03 / 26 / 90$ & TA & $04 / 12 / 90$ & 1,438 \\
\hline & 807 & 7963 & Shell Offshore & 3 & $E$ & $04 / 21 / 90$ & ST & $05 / 10 / 90$ & 2,930 \\
\hline & 952 & 9905 & Shell Offshore & 1 & $E$ & $05 / 02 / 90$ & & $06 / 27 / 90$ & 6,660 \\
\hline & 441 & 5080 & EP Operating & 5 & $E$ & $05 / 31 / 90$ & TA & $06 / 07 / 90$ & 1,431 \\
\hline & 243 & 7927 & Conoco & 1 & $E$ & $06 / 27 / 90$ & & 07/01/90 & 2,902 \\
\hline & 854 & 9883 & Shell Offshore & 1 & $E$ & $07 / 10 / 90$ & & $08 / 02 / 90$ & 4,020 \\
\hline & 807 & 7963 & Shell Offshore & 3 & $E$ & $07 / 23 / 90$ & & DRL & 2,930 \\
\hline & 441 & 5080 & EP Operating & 6 & $E$ & $07 / 24 / 90$ & TA & $08 / 21 / 90$ & 1,531 \\
\hline & 854 & 9883 & Shell Offshore & 2 & $E$ & $08 / 15 / 90$ & & DRL & 4,020 \\
\hline & 160 & 9787 & ARCO & 1 & $E$ & $09 / 06 / 90$ & & $11 / 06 / 89$ & 2,707 \\
\hline & 881 & 7967 & Exxon Corp. & 1 & $E$ & $09 / 14 / 90$ & & DRL & 1,964 \\
\hline & 807 & 7963 & Shell Offshore & 4 & $E$ & $10 / 30 / 90$ & & DRL & 2,956 \\
\hline \multirow[t]{6}{*}{ Viosca Knoll } & 869 & 5784 & Exxon Corp. & 2 & $E$ & $05 / 23 / 89$ & & $06 / 14 / 89$ & 2,050 \\
\hline & 957 & 8475 & Amoco Prod. & 1 & $E$ & $06 / 22 / 89$ & TA & 07/04/89 & 3,500 \\
\hline & 826 & 6888 & Oryx Energy & 2 & $E$ & $01 / 12 / 90$ & ST & $01 / 27 / 90$ & 1,726 \\
\hline & 826 & 6888 & Oryx Energy & 3 & $E$ & $01 / 14 / 90$ & & DRL & 2,000 \\
\hline & 826 & 6888 & Oryx Energy & 2 & $E$ & $02 / 03 / 90$ & & $02 / 26 / 90$ & 1,726 \\
\hline & 825 & 5778 & Exxon Corp. & 2 & $E$ & $07 / 18 / 90$ & & $09 / 01 / 90$ & 1,575 \\
\hline $\begin{aligned} E & =\text { exploration } \\
D & =\text { development } \\
D R L & =\text { drilling } \\
T A & =\text { temporarily aban } \\
S T & =\text { sidetrack } \\
O S I & =\text { drilling shut }-1 n \\
C O M & =\text { completed }\end{aligned}$ & & & & & & & & & \\
\hline
\end{tabular}




\section{Pacific OCS Region}

There have been 329 exploratory wells spudded on the Pacific OCS since the first exploratory well was spudded by Shell Oil Company in the Central California Planning Arca in 1963. From 1963 through 1967, a total of 38 exploratory wells were drilled by six offshore operators in all four of the Pacific OCS planning areas; this includes six wells drilled on drainage tract Lease OCS-P 0166 in the Carpinteria field.

Following Phillips Petroleum Company's delineation drilling in Federal waters of the extension of the Carpinteria Offshore oil field in 1967, exploration activities focused on the Southern Califomia Planning Arca, with a record number of 38 exploratory wells drilled on the Pacific OCS in 1968. This exploratory activity in 1968, which led to the discovery of the Dos Cuadras, Govermment Point, and Pitas Point fields in the Santa Barbara Channel, increased industrys interest in the oil and gas potential of the Pacific OCS Region.

On January 28, 1969, a blowout occurred at Union s Platform $A$ in the Dos Cuadras field, resulting in a major oil spill. This event caused a public outcry against oftshore drilling and prompted the Secretary of the Interior to suspend all operations on Federal leases in the Santa Barbara Channel for several years.

As a result of the first lease sale in the Pacific OCS Region following the Santa Barbara Channel oil spill, exploration activities increased from $197+$ through 1977, as industry further defined the oil and gas potential of the Southern California Planning Area. After a slight decline, exploration began a steady increase in the early 1980\%, as lease sales in both central and southern California offered new acreage for offshore operators to explore.

In 1983 and 1984. industry began an extensive search in the Monterey Formation off southern California. This search resulted in 18 wells being determined to be producible by MMS. Since this time. the pace of exploratory drilling in the Pacific OCS has declined, as offshore operators focused their attention on development and production operations.

The success of the Pacific OCS exploratory drilling program is evident with the discovery of 37 offshore fields in this region. Each of these fields is located in the five offshore development regions discussed in the next section. Figure 3-11 (below) displays the number of exploratory wells drilled by planning area per year on the Pacific OCS. Table 3-6 (p. 108) provides annual totals of wells drilled by map area on the Pacific OCS. Figure 3-12 (p. 109) depicts the location of these map areas. Each of these OPD's may be ordered from the following office:

\section{Pacific OCS Region \\ Mincrals Management Service \\ 1340) West 6th St. \\ Los Angeles, CA 90017}

An oversized map plate of southem California offshore oil and gas activities and related onshore facilities is available from the Document Distribution Center (see address in the Preface to this report).

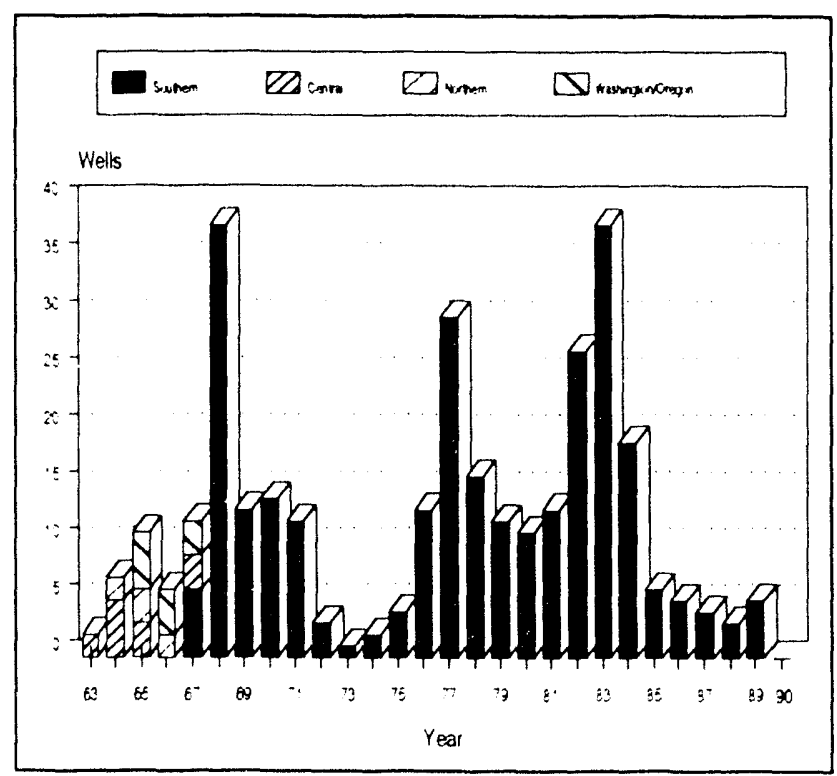

Figure 3-11. Exploratory wells drilled in the Pacific OCS Region by planning area, 1963-October 31, 1990. 
Table 3-6. Exploratory wells drilled in the Pacific OCS Region, by OPD location number, 1963-October 31, 1990

[Includes two deep stratigraphic test exploratory wells - 6D (1975) and N1 10-6 (1978)]

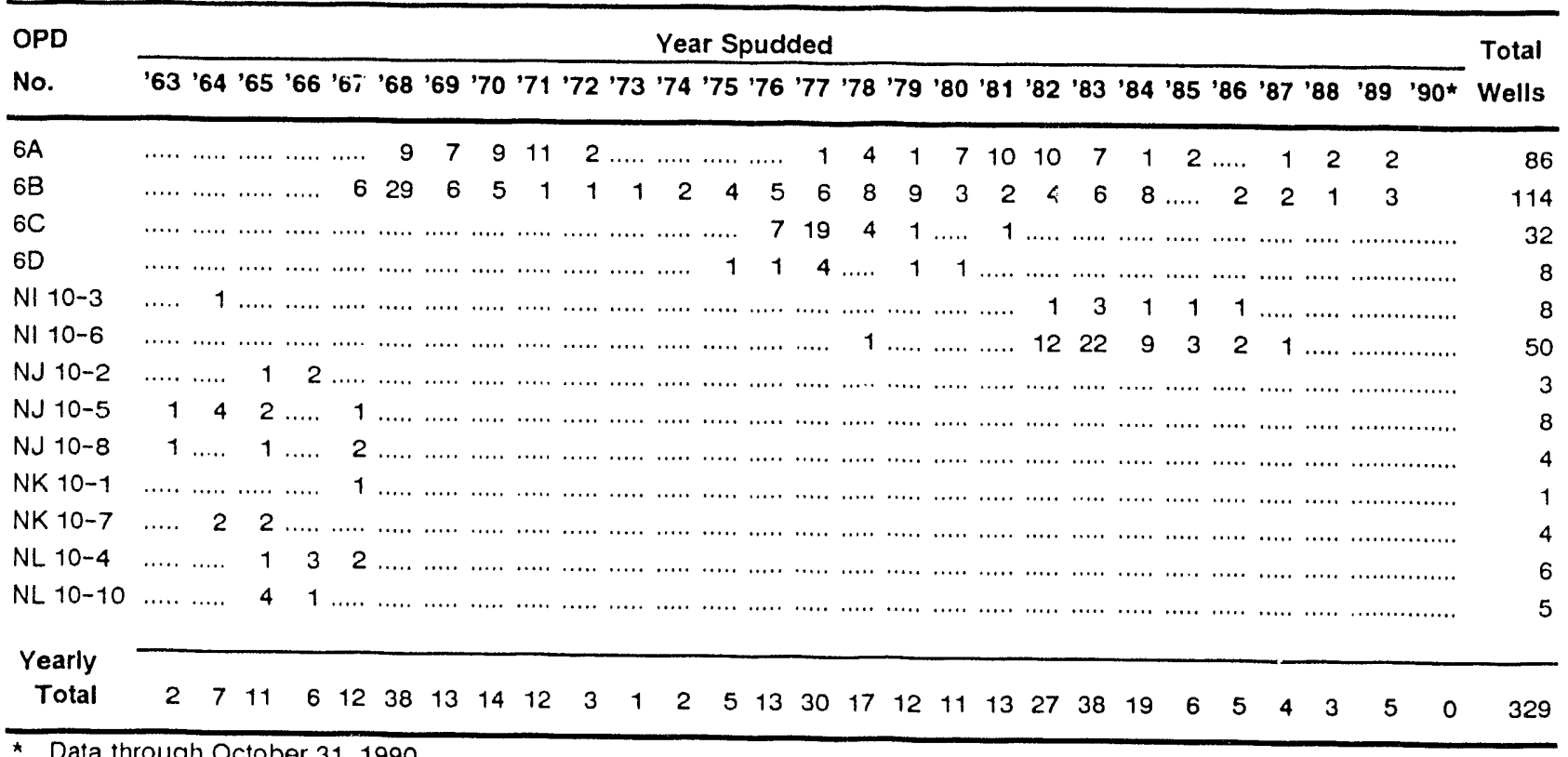




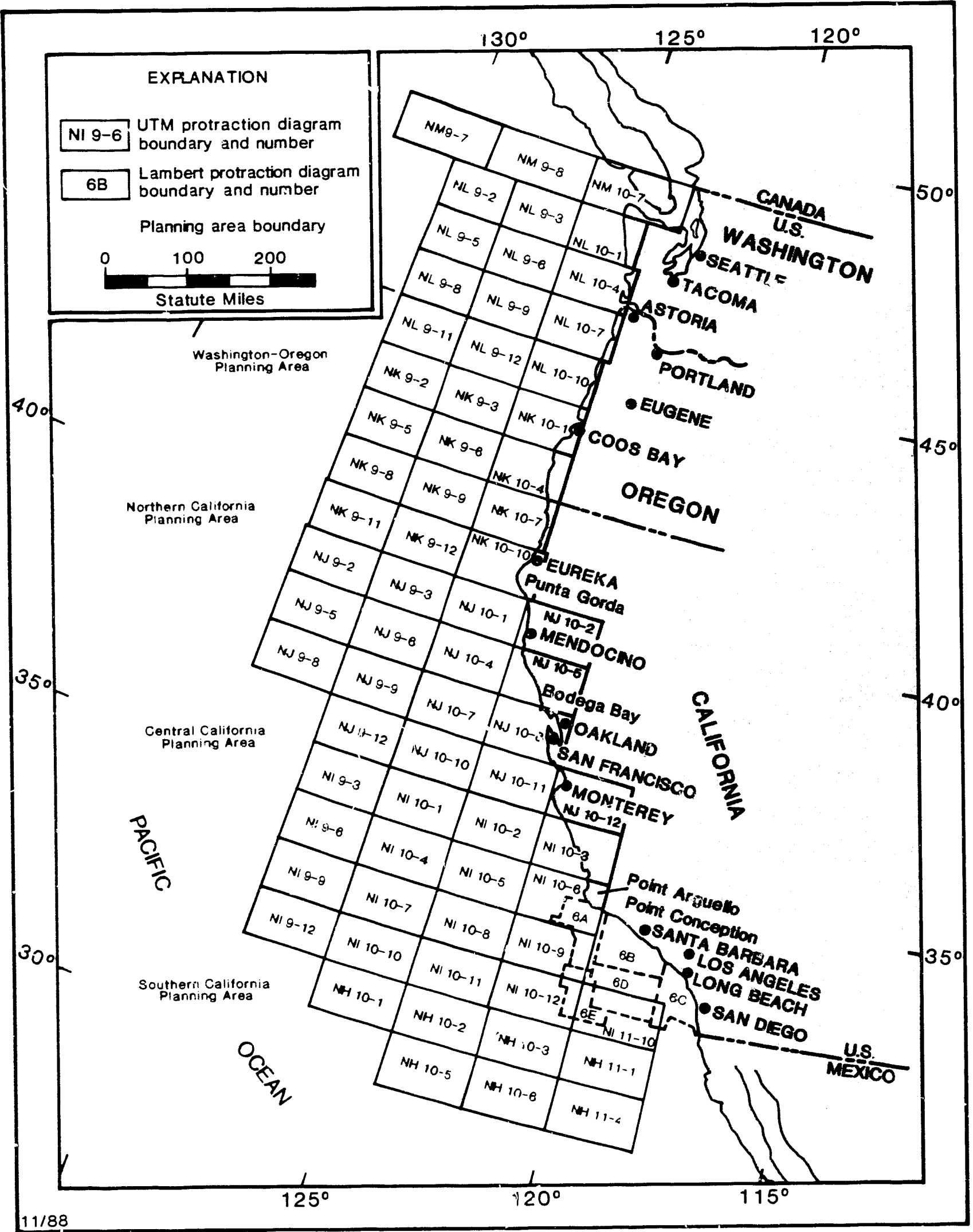

Figure 3-12. Pacific OCS Region official protraction diagram locations. 


\section{Development Phase of Postlease Activities}

The development phase of the postlease process begins when a company determines that production fiom a discovery is economically feasible. Before development can proceed, a detailed Development and Production Plan (DPP), or a Development Operations Coordination Docurnent (DOCD) for areas in the western Gulf of Mexico, is prepared by the company and reviewed and approved by MMS. A DPP must include (1) the specific work to be performed; (2) a description of drilling vessels, platforms, pipelines, or other facilities and operations located offshore and onshore, including safety and pollution prevention and control features and labor, material, and energy requirements; (3) the well locations; (4) current interpretations of all available relevant geological and geophysical data, which may include proprietary data; (5) a description of environmental safeguards and safety standards; (6) a time schedule of development and production activities; (7) an oil-spill contingency plan that sets forth the procedures, personnel, and equipment to be used for preventing, reporting, and cleaning up spills of oil and waste material; and (8) such data as the MMS Director may require. (For a more detailed description of what is required in a DPP, refer to the April 1, 1988, Federal Register notice, related to 30 CFR Parts 250 and 256, p. 10706.) A flow chart of the MMS development and production plan review process is presented in figure 3-13 (p. 111). After the necessary permits and approvals have been obtained, one or more platforms are installed to develop and produce the discovery.

\section{Alaska OCS Region}

Although several discoveries have been made on the Alaskan OCS, including eight wells receiving determinations of producibility by MMS within the Beaufort Sea Planning Area, no development or production activities have yet been undertaken. Because of the current uncertain market conditions and the high development and transportation costs, large field or multiple field discoveries in nearby leases may be necessary to justify the cost of codeveloping these areas. Once the offshore infrastructure is in place in the region, however, these discoveries, along with a number of the smaller discoveries, may then become commencially viable. This offshore infrastructure can then be linked to the onshore infrastructure already in place as a result of production from a number of large discoveries within the State of Alaska.

\section{Atlantic OCS Region}

As is the case in the Alaska OCS Region, there is no development or production in the Atlantic OCS Region. There have been a few small discoveries of oil and natural gas in the Mid-Atlantic Planning Area off the coast of New Jersey. If these discoveries had been made in a region having an established infrastructure, such as the Gulf of Mexico, these discoveries would have been determined commercial.

\section{Gulf of Mexico OCS Region}

Historically, development in the Gulf of Mexico, like all other aspects of the Federal OCS Program, is greatest in the central Gulf of Mexico. This trend is still continuing today. There have been no development activities in the Eastern Gulf of Mexico Planning Area. Figure 3-14 (p. 112) shows the number of development wells drilled in the Gulf of Mexico OCS Region by planning area and year. Table 3-7 (p.113) lists the number of development wells drilled by map area. Figures 3-15 and 3-16 (p. 114 \& p. 115) present the location of each of these map areas. Each of these maps may be ordered through the Gulf of Mexico OCS Regional office at the following address:

Gulf of Mexico OCS Region

Mincrals Management Services

1201 Elmwood Park Blvd.

New Orleans, LA 70123-2394 


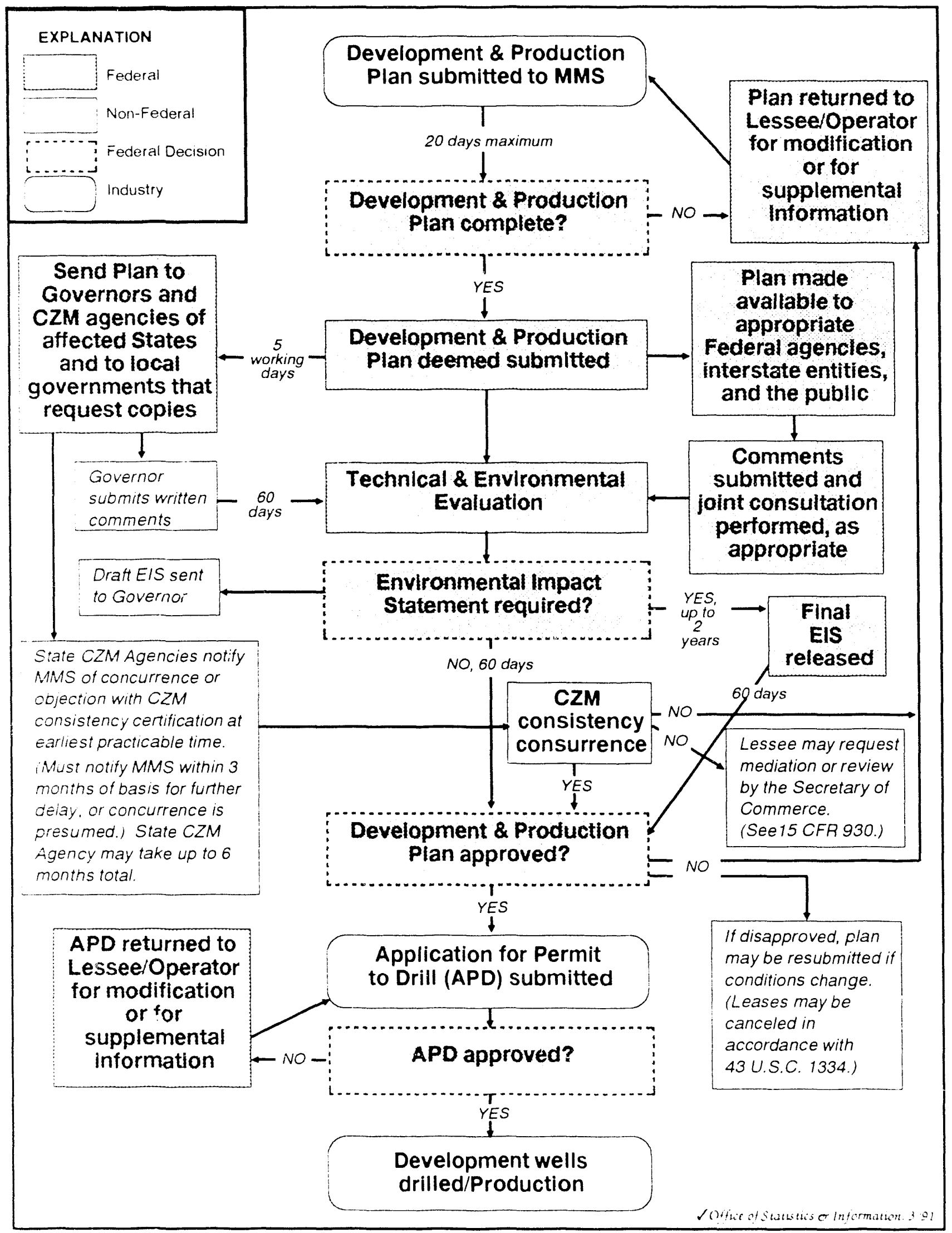

Figure 3-13. Development and production phase of postlease activities. 


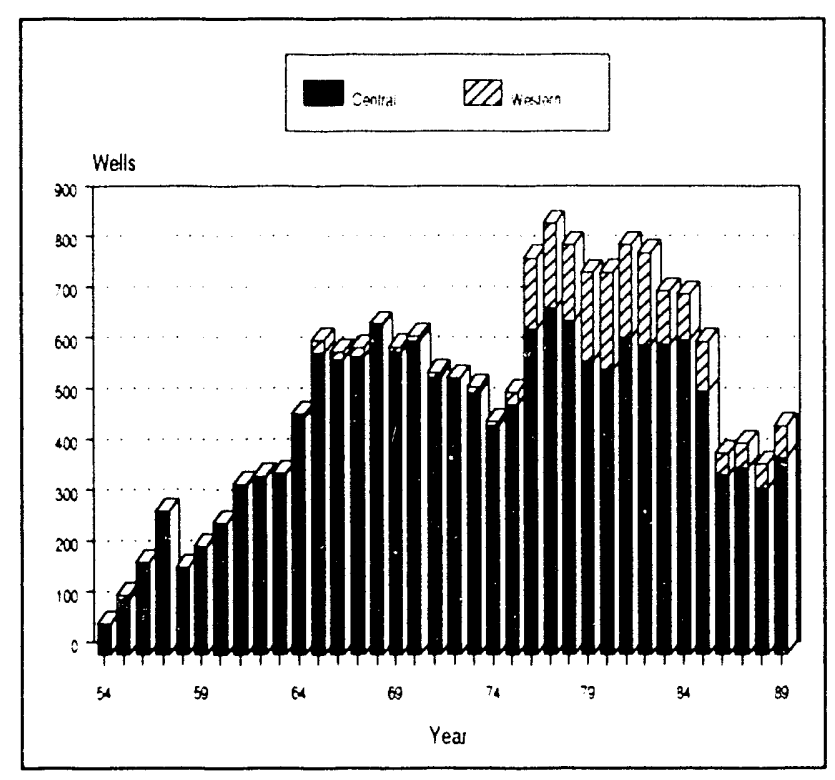

Figure 3-14. Total number of development wells drilled in the Gulf of Mexico OCS Region, by planning area, 1954-89.

Development of the oil and gas resources of the Gulf of Mexico OCS has declined significantly since 1985. In 1988, development activity reached a 25-year low, as many offshore operators placed development operations on hold and focused their attention on exploration activities. Development activity during this period was focused on tracts leased before 1979. This reflects operator's efforts (1) to enlarge production or (2) to extend the life of currently producing reservoirs or (3) to find decper zones within existing fields (Offshore, January 1989. Pennwell Publishing Co., vol. 49, no. 1, p. 20-23.).

While development activities were down, historical trends within the region continued. Twice as many plans covering proposed development activities were approved by MMS for the Central Gulf of Mexico OCS Planning Area during the period of 1988 through 1989 than there were for the Western Gulf.

As table 3-8 (p. 117) indicates, development in the deeper waters of the Gulf of Mexico is progressing. In 1988, 1989, and 1990, several companies submitted plans for additional deepwater development. Since 1988, several new deep-water records were set from development activities in the Central Gulf of Mexico.

Placid Oil Company set several new records as production from its Ewing Bank Block 999 and Green Canyon Block 31 started in October 1988. The project implemented the first floating/subsea production system composed of a modified semisubmersible that is linked by a pipeline system to a shallow-water processing platform. The Ewing Bank Block 999-1 subsea satellite well established a new Gulf of Mexico water-depth production record of 1,462 feet. This depth surpassed the 1,()25-foot mark held by Shell Offshore, Inc.'s Platform Cognac. However, this record-as well as the world record of 1,613 feet - held by Petroleo Brasilerio SA's 3-RJS-376-D well in Marimba field off Rio de Janciro, was shattered when Placid Oil Co. began production from its Green Canyon 31-4 well in 2,243 fect on October 13, 1988. On May 5, 1989, Placid tied this record when it brought on stream its Green Canyon 31-6 satellite well in 2,243 feet of water. In April 1990, after 18 months of production, Placid Oil announced that it was abandoning the project because of disappointing production performance of the wells. This setback to deepwater production in the Gulf of Mexico was not caused by the technology used to develop the prospect, it was caused by poor production from the geologic formation. It is believed that the technology used for this project will be used to develop future deep-water Gulf of Mexico prospects.

On June 1, 1988, Shell Offshore, Inc. broke the world record for tallest offshore structure when it installed its Platform Bullwinkle in 1,350 feet of water on Green Canyon Block 65. Bullwinkle stands 1,615 fect tall eclipsing Exxon's Platform Lena, which held the record at 1,305 feet. Production while drilling began in July 1989, and first production through permanent production facilities is scheduled for late 1991. 


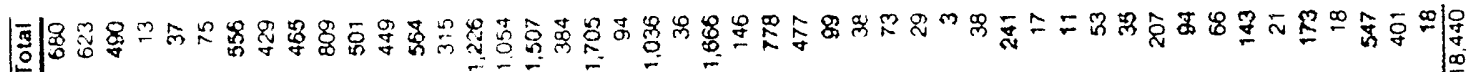

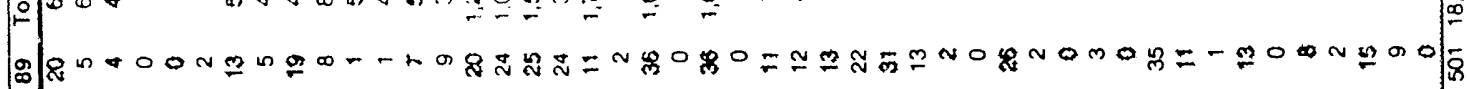
Da o mor

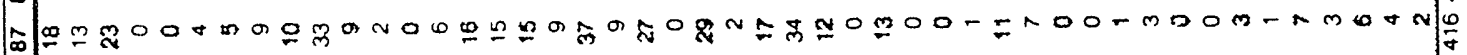

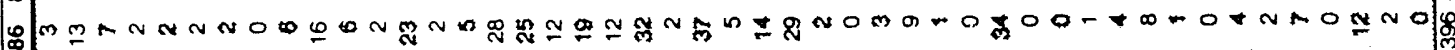

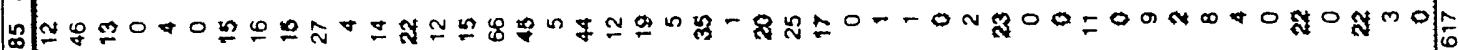
Б的- -

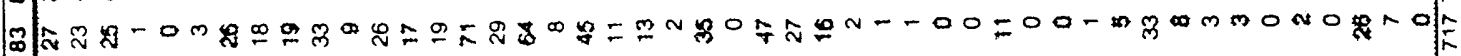

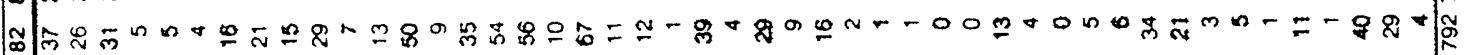

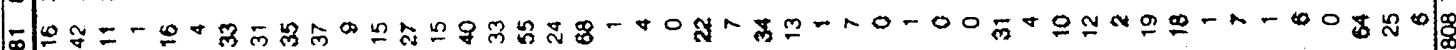

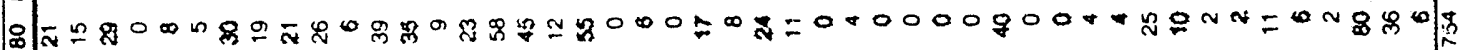

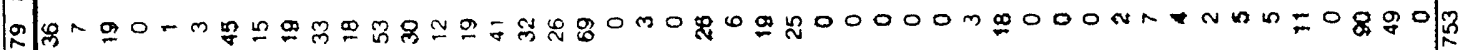

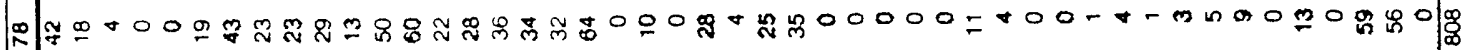

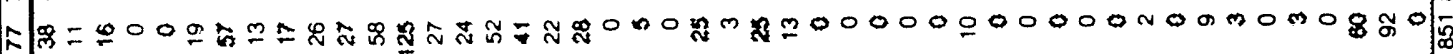
经 N $=\hat{s}$ О

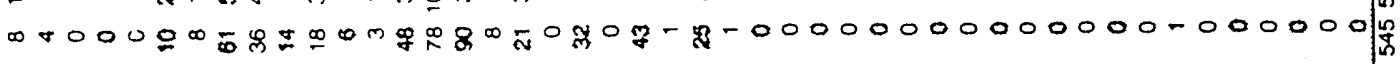
及

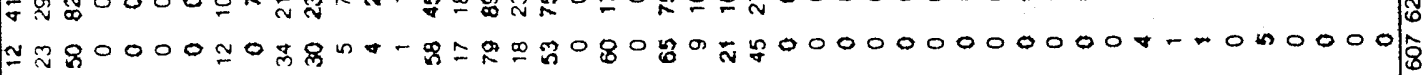
OND : Z

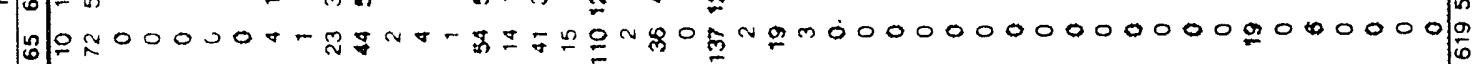




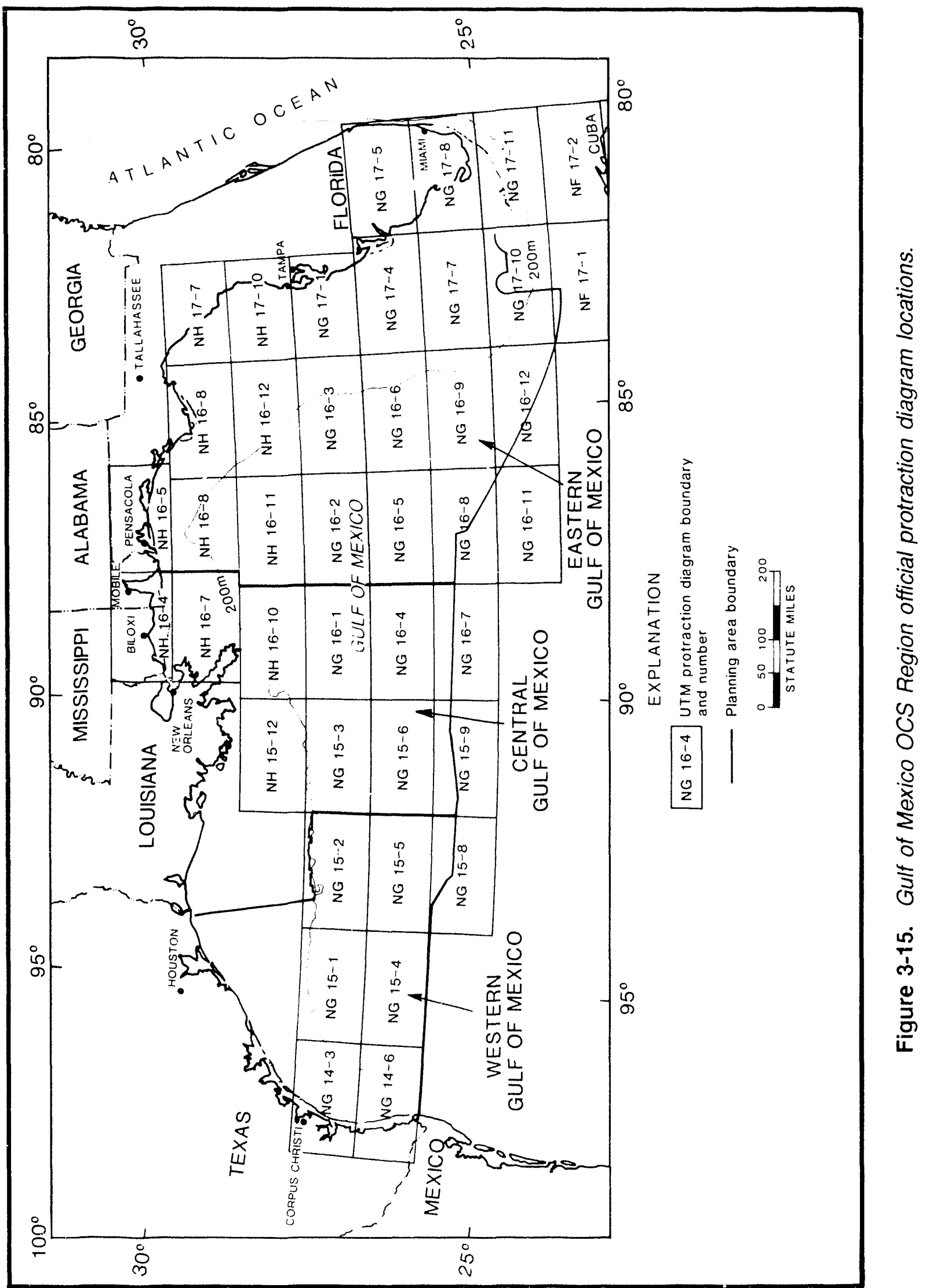




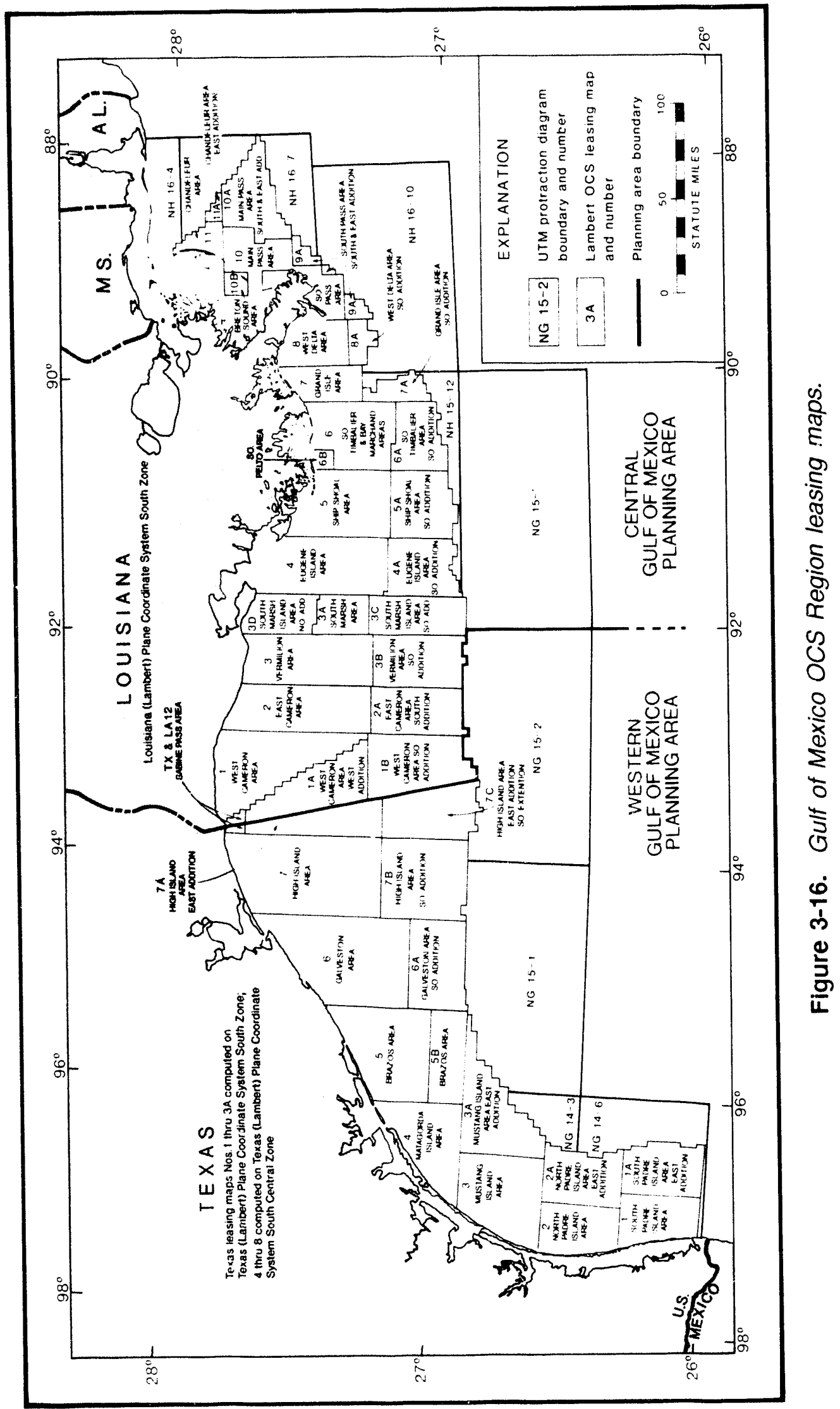


Conoco installed the first tension-leg well platform (TLWP) in the Gulf of Mexico on Green Canyon Block 184. In September 1988. Conoco, Inc. and partners landed the 1,4())-ton foundation template that will anchor its Jolliet ficld TLWP in 1,760 feet of water. Fabrication of the TLWP at Singapore's Far East-Levingston Shipyard was completed in April 1989. The platform arrived in the Gulf of Mexico on May 26, 1989, and installation began the week of June 19, 1989. On June 23, 1989, four of the structure's tendons sank in about 3,000 feet of water enroute to the Jolliet field installation site in Green Canyon Block 184. Following the incident, Conoco, MMS, and the Coast Guard met and reviewed a plan to temporarily install the TLWP with only eight tendons, until replacement tendons are built. On July 11, 1989, Conoco resumed installation of the TLWP after agreeing with MMS and the Coast Guard that production from the 20 wells already drilled would not begin until the four missing tendons were replaced. Conoco completed installation of the platform in October 1989, and production from the first TLWP in the Gulf of Mexico began in November 1989. Conoco has announced plans to begin preliminary engineering, late in 199(), on a second TLWP for an additional Gulf of Mexico deep-water prospect that the company is now exploring.
Shell Oil Company recently announced plans to develop its Auger Prospect located on Garden Banks Block 426. The prospect, located in 2,860 feet of water, will set a new world decpwater production record, when completed. Shell plans to use a TLWP similar to the one used by Conoco to develop its Jolliet field. In August 1990, Shell awarded the contract to two companies, McDermott, Inc., located in Louisiana and Belleli, Inc., an Italian company. Shell will begin delineation drilling in May 1991. Installation of the TLWP is planned for 1993, and production is scheduled to commence in late 1993.

Texaco has placed development plans for the deep-water Thor field encompassing Viosca Knoll Blocks 825, 869, and 870, which are on hold. The operator had filed a DOCD with MMS, which outlined plans for the installation of a TLWP in 1,850 feet of water by 1994 . Production from Blocks 825 and 869 was scheduled to begin in mid-1995. As of September 1990 , proposed installation and production dates were uncertain. 
Table 3-8. Selected Gulf of Mexico OCS Region deep-water projects as of October 31, 1990

\begin{tabular}{|c|c|c|c|c|}
\hline $\begin{array}{l}\text { Adminlstratlve area/ } \\
\text { block number }\end{array}$ & Operator & $\begin{array}{l}\text { Water } \\
\text { depth } \\
\text { (ft) }\end{array}$ & $\begin{array}{l}\text { Production structure/system } \\
\text { (Project name) }\end{array}$ & Status \\
\hline Green Canyon 184 & Conoco & 1,760 & $\begin{array}{l}\text { Tension-leg well platform } \\
\text { (Jolliet field) }\end{array}$ & Producing since November 1989. \\
\hline Green Canyon 21 & ODECO & 1,270 & Subsea System & $\begin{array}{l}\text { June } 1990 \text { commenced design } \\
\text { stage. Production startup } \\
\text { planned for December } 1992 \text {. }\end{array}$ \\
\hline Green Canyon 110 & Marathon & 1,300 & $\begin{array}{l}\text { Floating production, storage } \\
\text { and offloading (FPSO) platform }\end{array}$ & $\begin{array}{l}\text { Development feasibility study } \\
\text { completed November } 1990 \text {. } \\
\text { Engineering and design to start } \\
\text { December } 1990 \text {. Installation } \\
\text { planned for Fall 1992, production } \\
\text { planned for late 1992. }\end{array}$ \\
\hline Green Canyon 65 & Shell & 1,350 & $\begin{array}{l}\text { Fixed steel platform } \\
\text { (Bullwinkle) }\end{array}$ & $\begin{array}{l}\text { Platform installed June } 1988 . \\
\text { Production while drilling } \\
\text { started July } 1989 \text {. Full production } \\
\text { expected late } 1991 .\end{array}$ \\
\hline $\begin{array}{l}\text { Green Canyon 29, } 31 \\
\text { and Ewing Bank } 999\end{array}$ & Placid & $2,243^{\star}$ & Floating production platform & Project abandoned April 1990. \\
\hline $\begin{array}{l}\text { Mississippi Canyon } \\
335,354,398,399\end{array}$ & Exxon & $1,211-1,600$ & $\begin{array}{l}\text { Floating production plattorm } \\
\text { (Zinc Prospect) }\end{array}$ & $\begin{array}{l}\text { Planning/engineering - } \\
\text { delayed. }\end{array}$ \\
\hline Mississippi Canyon 39 & Shell & 5,000 & Unknown & Project on hold. \\
\hline Mississippi Canyon 280 & Exxon & 1,001 & $\begin{array}{l}\text { Guyed-tower platform } \\
\text { (Lena) }\end{array}$ & $\begin{array}{l}\text { Producing/drilling for new } \\
\text { horizons. }\end{array}$ \\
\hline Mississippi Canyon 194 & Shell & 1,025 & $\begin{array}{l}\text { Fixed steel plattorm } \\
\text { (Cognac) }\end{array}$ & Producing since 1982. \\
\hline Viosca Knoll 869 & Texaco & $1,850-2,400$ & $\begin{array}{l}\text { Tension-leg well platform } \\
\text { (Thor field) }\end{array}$ & On hold. \\
\hline $\begin{array}{l}\text { Garden Banks } \\
\text { Block } 426\end{array}$ & Shell & 2,860 & Tension-leg platform & $\begin{array}{l}\text { Delineation drilling. Installation } \\
\text { planned for } 1993 \text {. Production } \\
\text { startup planned for } 1993 \text {. }\end{array}$ \\
\hline $\begin{array}{l}\text { Mississippi Canyon } \\
\text { Block } 109\end{array}$ & $B P$ & 1,030 & Fixed steel platform & $\begin{array}{l}\text { Platform under construction. } \\
\text { Installation planned from Summer } \\
\text { 1991. Production startup } \\
\text { planned for late } 1991 .\end{array}$ \\
\hline
\end{tabular}




\section{Pacific OCS Region}

The first development well was drilled in the $\mathrm{Pa}$ cific OCS Region in 1968. As figure 3-17 (right) shows, the number of development wells drilled in the Pacific OCS Region peaked in 1969, and then again in 1982. As table 3-9 (p. 119) shows, a total of 705 development wells were drilled on the Pacific OCS as of October 31, 1990. This table also presents the name and location of each of the platforms used to drill these wells.

Because of the limited number of projects in the Pacific OCS Region as compared with the Gulf of Mexico OCS Region, the following detailed discussion is provided. Included in this section are discussions of the onshore support facilities necessary to complete these projects.

\section{Point Arguello and Gaviota Interim Marine Terminal}

The Point Arguello field, located in the southern Santa Maria Basin offshore Santa Barbara County, 10 miles off Point Conception, 55 miles northwest of the city of Santa Barbara, and 150 miles northwest of Los Angeles, was discovered by Chevron in 1981 . This field is the largest U.S. discovery since the giant Prudhoe Bay field was discovered in 1967. Chevron is the principal operator of the project, leading a consortium of 17 additional oil companies, including Texaco, Phillips, Pennzoil, and Oryx. After more than 5 years in the permitting process, Chevron and Texaco had secured the requisite permits for both the onshore and offshore components of their DPP for this project. Under the terms of their permits, Chevron and Texaco will funnel all production from the Point Arguello field to Chevron's Platform Hermosa from which production will be piped to shore in two pipelines. The landfall for these two pipelines lies just north of Point Conception; the onshore route parallels the coastal terrace from the landfall to a new oil and gas processing facility built at Gaviota by Chevron. Oil will be transported in a 24-inch line by the Point Arguello Pipeline Company (PAPCO), and natural gas will be transported in a 20 -inch line by

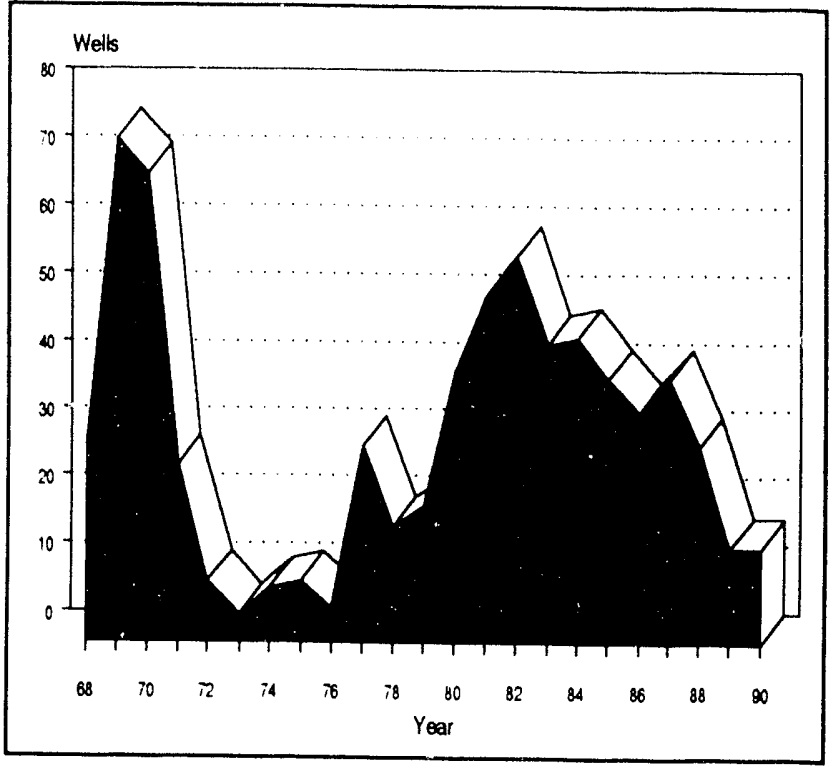

Figure 3-17. Number of development wells drilled in the Pacific OCS Region, 1968-October 31, 1990.

the Point Arguello Natural Gas Line Company (PANGL). The above two pipelines are known together as the Point Arguello Offshore System (PAOS). This project has gone through an extensive review process over the past 9 years, with several proposals presented. The following discussion provides a summary of some of the major events which have taken place to date.

As originally proposed, oil would be dehydrated at the Gaviota/PAPCO oil separation and treatment plant. After dehydration, up to $100 \mathrm{Mbpd}$ of the crude initially would be transported by tanker from Texaco's Gaviota Interim Marine 'Terminal to Chevron's and Texaco's refineries in the Los Angeles area (see discussion on the Gaviota terminal that follows). Crude would be transported by pipeline to Los Angeles in the future if the Southern California Pipeline System (SCPS) is built. Plans also called for the PAPCO oil plant to be connected to the new consolidated marine terminal proposed for offshore Las Flores Canyon, if it is built. 


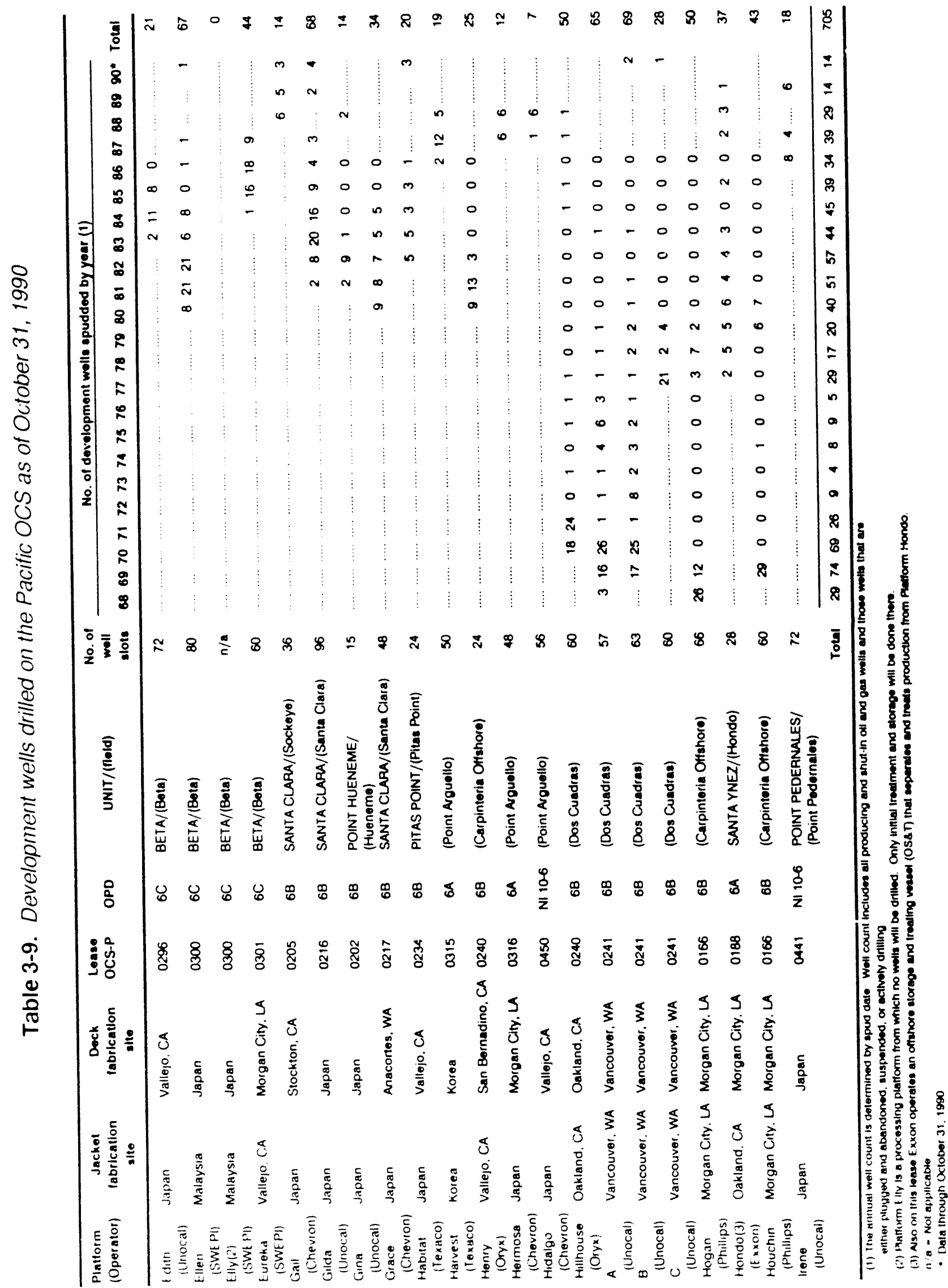


Natural gas would be processed at an adjoining facility operated by the Gaviota Gas Plant Company (GGPC). Clean sales-gas processed by the GGPC would be sold to the Southern California Gas Company (SoCal) and tied into one of SoCal's existing distribution pipelines that crosses the plant property. Natural gas liquids (NGL) and liquid petroleum gases (LPG) would be blended with the crude oil for transport to markets in the Los Angeles and Bakersficld areas by truck until a pipeline could be built for this purpose.

As a condition established by the Joint Review Pancl, the combined EIR/EIS that was prepared for the Point Arguello project included a southern Santa Maria Basin area study that attempted to consider foresecable development through 1993. As a result of this study, the offshore pipeline network and the PAPCOGGPC plant at Gaviota are sized to accommodate future production up to $250 \mathrm{Mbpd}$ of crude oil emulsion and $120 \mathrm{MMcfd}$. Chevron is studying development of its Rocky Point Unit that would entail installation of Platform $\mathrm{Ha}$ cienda on Lease OCS-P ()451. This platform was the only one projected by the Southern Santa Maria Basin area study. If Platform Hacienda is erentually installed, resulting production would be ticd into the PAPCO and PANGL lines and transported to Gaviota for separation and treatment and processing.

Chevron and Texaco installed Platform Hermosa on Lease OCS-P 0316 and Platform Harvest on Lease OCS-P (1)315, respectively, during 1985; Chevron subsequently installed Platform Hidalgo in 1986. The PAPCO and PANGL pipelines were installed during 1986 and early 1987 from Platform Hermosa to the PAPCO-GGPC facility at Gaviota.

Initial startup of this project was delayed because of concern over onshore pipeline safety. In May of 1988, the County decided to prepare a supplemental environmental impact report (SEIR) to assess the potential public safety and environmental impacts caused by the higher levels of hydrogen sulfide in the produced gas.
The draft SEIR was published on August 5, 1988. The public comment period for the draft SEIR closed September 9, 1988.

Initial permitting for an expansion of the existing Gaviota Marine Terminal as a multipleuse industry facility was undertaken by Getty Oil in early 1983 before its merger with Texaco. On February 26, 1985, the Santa Barbara County Planning Commission, and later the Board of Supervisors, conditionally approved Gaviota as the preferred site for a consolidated marine terminal on the County's south coast. This decision was made in response to an alternative marine terminal siting study conducted as part of the draft EIR for the Gaviota proposal. On April 4, 1985, Exxon, Texaco, and Chevron (later joined by Sun and Phillips) asked the County Board of Supervisors to withdraw the Texaco application in favor of establishing the consolidated marine terminal at a site offshore Las Flores Canyon. As part of this proposal, the companics proposed using the Gaviota terminal on an interim basis until pipelines to Texas and to the Los Angeles area were built, or until the proposed new consolidated marine terminal was built at the Las Flores site (see related development in the Santa Ynez Unit). The companies proposed to own and operate the facility through the Gaviota Terminal Company.

In October 1985, the County approved proposals for both the Gaviota Interim Marine Terminal and the Las Flores Consolidated Marine Terminal. This approval authorized facility expansion and loading eperations at the Gaviota terminal until July 1,1990 . At that time, neither the aforementioned pipelines nor the consolidated marine terminal was constructed; therefore, the Gaviota Terminal Company had to petition the County to continue operations. If either of these options were available, the offshore moorings would have been removed and offshore pipelines would have been sealed and abandoned in place. The company could have retained the newly approved tanks for use as a pipeline storage station, but other storage facilities would have been removed. Neither 
option was available. The permit has been ex tended to July 1991, when it will be reviewed by the Santa Barbara County Board of Supervisors for permit compliance. The company can operate now on a temporary basis, if permit conditions are met.

As approved in May 1987 by the County Planning Commission and the Board of Super visors, the Gaviota Interim Marine Terminal consists of (1) total onshore oil storage tank capacity of $753 \mathrm{Mbbl}$, including existing capacity of $275 \mathrm{Mbbl}$, an addition of two new 239-Mbbl tanks and, if needed, a later addition of one new $8(0-\mathrm{Mbbl}$ tank: (2) a relocated 6 point offshore mooring situated $3,5(0)$ feet offshore in water about 60 feet deep at mean tide; and (3) a dedicated fleet of tankers that average 4).(1)(0) deadweight tons (dwt) and are specially modified to work with the vapor-recovery system at the terminal and will transport the crude sil mainly to Los Angeles area retineries.

On July 9, 1987, the county issued a Coastal Develepment Permit and Building Permit to Gaviota Terminal Company, a general partnership managed by Texaco Trading and Transportation, Inc. Onshore construction of the Gaviota Interim Marine Terminal began on July 10, 1987. Initial capacity of the terminal is expected to be about $43 \mathrm{Mbpd}$ with expansion up to 100) Mbpd, if needed.

The proposed onshore pipeline from Santa Barbara County to the Los Angeles Basin retineries near Long Beach was rejected by Los Angeles and other municipalities several years ago. Chevron then requested a permit w tanker the oil wo the Los Angeles refineries on a temporary basis, until a pipeline can be built or existing pipelines used. Santa Barbara County issued such a permit in 19x9. The Calitornia Coastal Commission revolied the permit after communty groups appealed the permit. Chevron then filled suit against the Codstal Commisson. The suit is still pending. Chevron issued a new tankering request. Santa Barbara County released a new environmental report on tankering in August 1990. Public review and hearings will follow. A final county vote on temporary tankering is expected in November 1990).

As of October 1990, production has not occurred. The three offshore drilling platforms, the connecting offshore pipelines and pipeline to shore, and the onshore treatment facility at Gaviota, have been completed and reary to begin operation since late 1987. The project has been estimated to cost $\$ 2.5$ billion, and contain between 200 and $3(0)$ MMbbl of oil. The project could produce as much as $100 \mathrm{Mbpd}$ of oil and 60 MMcfd of natural gas. Currently the project has been mothballed, after over 8 years of permitting reviews from 44 regulatory agencies and compliance with 160 permit conditions. The Department of Energy offered assistance in resolving the project conflicts after the August 2, 1990). Iraqi invasion of Kuwait and the subsequent rise in oil prices and concern for the domestic oil supply. Chevron prefers to wait until the November 1990 county decision. Chevron is considering adding either heaters to move the heavy, viscous Point Arguello crude oil to the existing Four Corner's Line 90 miles into Los Angeles or building a new line along the Sante Fe Southern Pacitic railway corridor from Gaviota through the San Fernando Valley to Los Angeles. For either alternative it is expected to take $24-30$ months (1) obtain all the necessary permits. Chevron hopes to tanker the crude to Los Angeles temporarily, until a pipeline is available. Chevron cstimates that even with a speedy approval of the temporary tankering, it will take at least 6 months for the project to start producing.

\section{Santa Ynez Unit and Las Flores Canyon}

The Santa Ynez Unit is currently composed of 20 leases covering 97.437 acres that were acquired by Exxon and others in the 1968 Santa Barbara Channel lease sale. The first discovery in this area occurred in August 1968 on lease OCS-P 0197. Additional drilling has resulted in the discovery and delineation of four oil and gas fields within the unit. These are the Sacate, Pescado, Hondo, and Government Point fields. A DPP for the Santa Ynez Unit was approved 
by the U.S. Geological Survey (USGS) in 1974. Exxon subsequently installed Platform Hondo in June 1976; production from Hondo began on April 2, 1981. The first of a series of revised DPP's was submitted to the MMS in 1982. The revised DPP proposed (1) three or four additional offshore platforms to develop the three remaining unit fields, (2) consolidated processing facilities at Las Flores Canyon, (3) a consolidated marine terminal at Las Flores, (4) a consolidated storage facility in Corral Canyon, and (5) subsea and onshore pipelines to connect these components.

In 1984, the Santa Barbara County Board of Supervisors gave preliminary approval to all portions of Exxon's Preliminary Development Plan for the onshore components of the project except for the marine terminal. The County attached a condition to the project, however, requiring oil to be transported by pipeline out of the County. Exxon sued the County on this condition, claiming the County lacked jurisdiction to impose this requirement. Exxon subsequently agreed to drop the lawsuit when the County gave final approval of their project. In October 1985, the County approved the use of the existing Texaco (formerly Getty) Gaviota Marine Terminal on an interim basis until pipeline transportation to Los Angeles and Texas was available, or until the Las Flores (Exx.on) Marine Terminal was operational.

In December 1985, the Santa Barbara County Board of Supervisors and Exxon began meetings in an effort to resolve air-quality disagreements on the project. Exxon revised the project by reducing the number of proposed off shore platforms from four to three and by dropping their plans to build a gas-processing facility in Las Flores Canyon. By February 1986, Exxon had agreed to abandon using the offshore storage and treating (OS\&T) vessel and process production onshore in exchange for renegotiating the conditions of its onshore permit.

On March 19, 1986, Exxon and the County reached a tentative agreement on the Santa
Ynez Unit project. Exxon agreed (1) to build a 140-Mbpd processing plant in Las Flores Canyon, (2) to ship oil out by pipeline, and (3) to not expand the existing Pacific Offshore Pipeline Company plant from its current permitted capacity of 60-135 MMcfd. In return, the County agreed (1) that photochemical modeling for air quality would not be employed unless required; (2) that removal of the OS\&T could be used as an emissions offset to the extent allowed by the Clean Air Act; (3) on a definition of net air-quality benefit; (4) on a reopener clause that would allow future review of the effectiveness of air-quality mitigation and allow for additional measures if reasonable and feasible; and (5) to defer the County versus Hodel lawsuit, which the County had filed against the Department for not imposing what the County considers to be feasible mitization measures on Exxon's proposed offshore platforms. Finally, the two sides agreed (1) that the County could halt or slow onshore oil processing if the air quality worsens as a result of offshore oil production and (2) on steps that would give the County a reopener clause after 3 years of monitoring nitrous oxide $\left(\mathrm{NO}_{\mathbf{x}}\right)$.

Subsequent to negotiations between Santa Barbara County and Exxon, the Santa Barbara County Planning $\mathrm{C}$.mmission approved Exxon's Final Development Plan for the Santa Ynez Unit on September 15, 1987. The California Coastal Commission (CCC) reviewed the Final Development Plan and granted its concurrence to Exxon's consistency determination on February 23, 1988. After the review by various Federal and State agencies, MMS approved Exxon's revised DPP for the Santa Ynez Unit on April 4, 1988. On April 8, 1988, Exxon began initial construction for the onshore components of its Santa Ynez Unit DPP in Las Flores Canvon. Construction activities over the next 18 months entailed excavation for facility pad space and the LPG/NGL loading facility pad. Installation of the onshore pipelines was near completion in Juiy 1990). As of October 31,1990 , both the onshore and nearshore pipelines have been completed. Corstruction of the offshore pipelines will begin in January 
1991. The jackets for Platforms Harmony and Heritage have been installed; however, the topsides have not been installed yet. Construction of the Las Flores Canyon main facilicies will begin when the land-use plan permits are issued. This is expected in the near future. Construction is expected to be completed in October 1992. On July 10, 1990, the California Coastal Commission issued the permit for the removal of the El Capitan Marine Terminal facilities.

Exxon was required to develop and comply with an Environmental Quality Assurance Program (EQAP). This program`s goals are to assure compliance with environmental protection permit conditions while facilitating project construction. The recently released Environmental Compliance Report indicated that the EQAP was an environmental success for all parties during the first phase of construction iSanta Barbara County Offshore Oil and Gas Status Report, August 1990).

\section{Point Pedernales Unit and Lompoc}

The Point Pedernales Unit is composed of six leases covering approximately 19,844 acres. After Unocal submitted a development application to Santa Barbara County in 1982 covering this unit, an areawide study was conducted to assess the cumulative effects of development in the Santa Maria Basin area. The areawide study included an analysis of cumulative impacts of Unocal's proposal and Exxon's proposed platform on adjacent lease OCS-P 0440.

Initial field development calls for production from Lnocal's Platform Irene on lease OCS-P $0+41$. Production from Platform Irene is transported by a pipeline that has its landfall north of the Santa Ynez River at the Vandenberg Air Force Base. The pipeline then runs inland 6 miles to a new $36-\mathrm{Mbpd}$ oil heating. separation, and pumping facility in Lompoc, and then on to two separate existing facilities for final processing of the oil and natural gas. The traatad oil is sent to Lnocal's Santa Maria refinery. Most of the cruus $: \because 1$ is then sent to
Unocal's Rodeo refinery in San Francisco for further processing. The natural gas is sent to Unocal's Batiles gas-processing plant near Santa Maria. From there the clean gas is sold and injected into a distribution network for local consumption. Unocal has agreed to limit throughput of OCS gas to $13 \mathrm{MMcfd}$ at the Battles facility, which was constructed in 1937. If expanded capacity is needed, the plant will be reconstructed or moved elsewhere. Unocal agreed to electrify the platform and obtain this power from a Pacific Gas \& Electric onshore substation located at Surf.

Exxon has a 100-percent interest in neighboring lease OCS-P 0440, where a discovery was made on October 8, 1983. Installation of Platform Iris (originally called Independence) on this lease is tentatively scheduled for 1992 . Under a recent agreement between Exxon and Unocal, Unocal will operatc the Platform Iris project. Plans call for production from Iris to use Platform Irf is pipelines to the treatment facility at Lompoc. From Lompoc, the County approved the crude oil to be transported in Exxon's proposed Lompoc pipeline that parallels an existing southern California gas pipeline right-of-way to a Celeron pipeline interconnect. Because of the recent Unocal-Exxon agreement mentioned above, it is doubtful whether this pipeline will be built.

On August 7, 1985, Unocal launched the 72slot Platform Irene jacket in 242 feet of water. This is the first platiorm to be set in the Lease Sale 53 area of the Santa Maria Basin. Unocal began construction on the Surf electrical substation 7 months later on: March 20, 1986. On April 27, 1986, develne 7t drilling began on Platform Irene.

Unocal began transporting production from Platform Irene to Lompoc on April 13, 1987, at approximately $10 \mathrm{Mbpd}$. Problems with sour gas were encountered, but Unocal and the County of Santa Barbara devised minor project modifications to overcome these. Production quickly reached approximately $20 \mathrm{Mbpd}$ of oil and 10 MMcfd of gas. 


\section{San Miguel and South Nipomo Mesa}

The discovery of the San Miguel field resulted from exploratory drilling by Cities Service on Lease OCS-P ()409. In July 1987, Shell Western Exploration \& Production. Inc., (SWEPI) became the designated operator and has subsequently purchased Cities Service's interest in this lease. The DPP proposed installation of the 72 -slot Platform Julius in 478 feet of water, 9.5 miles west of Point Sal. It was proposed that some separation and treatment occur on the platform and that the gas be reinjected. SWEPI currently has no plans to seli commercial gas. The DPP :' atifies a need for three pipelines to shor: an sil pipeline, a produced water pipeline, ind a service fuel pipeline. The operator's preferred location for the onshore oil separation and treatment facility is the South Nipomo Mesa area on Unocal land near the existing Unocal Santa Maria refinery. The DPP also calls for a 24-mile pipeline from the South Nipomo Mesa site to a Celeron pump station at Sisquoc in Santa Barbara County. This 24mile segment is known as the Celeron Interconnect and lies primarily within Santa Barbara County.

The Joint Review Panel established to guide preparation of the EIR/EIS for what is now Shell's project was chaired by San Luis Obispo County and consisted of three voting members (MMS. San Luis Obispo County, and the State Lands Commission) and three nonvoting members i Santa Barbara County, the CCC. and the Governor's Office of Offishore Development).

On June 7. 1988, San Luis Obispo County voters rejected the San Miguel development project. Through the legal basis for "Measure $A$ " and other similar locul oil initiatives is being tested in court. SWEPI has been furced (1) postpone the San Miguel project preferred altemative. SWEPI has since put Plattorn Julius up tor sale in korea, where it was built. It was originally built for Cities Services but desnt meet SWEPl's design specifications. SWEPI had an MMS-approved DPP for the offshore portion of the project, hut not for the on- shore support facilities due to the San Luis Obispo County referendum rejecting it. SWEPI may consider bringing the production ashore to Santa Barbara County instead. MMS has recently temporarily suspended the DPP permit until the rest of the project scenario is resolved.

\section{Santa Clara Unit}

In 1973, the Santa Clara Unit was approved by MMS s predecessor, the Conservation Division of the USGS, and Chevron was designated the unit operator. Chevron is the designated lease operator for seven of the eight leases in this unit. all of which were acquired by the lessees in OCS Lease Sale P4. The Santa Clara Unit contains two known fields: the Santa Clara field and the Sockeye field. Two platforms currently are producing the Santa Clara field: Chevron operates Platform Grace on Lease OCS-P (0217 and Unocal operates Platform Gilda on Lease OCS-P .216.

Chevron discovered the Sockeye field in 1970 on Lease OCS-P 0205. On January 29, 1986, MMS deemed Chevron's DPP for this lease acceptable. On November 14, 1986. MMS approved Chevron's DPP for development of the Sockeye field using Platform Gail located on Lease OCS-P 0205. Initial construction of this platform began on April 5, 1987. Chevron spudded its first development well from Platform Gail on June 16, 1988. Since that time Chevron has spudded several development wells; sustained production testing began in September 1988.

As a result of these projects, development well drilling in the Pacific OCS Region is likely to increase in the future as each of the proposed platfonms listed in table 3-10)( p. 125) is completed.

Chevron traneports production from Platform Sail to Platform Grace by a new pipeline. Produced oil and natural gas accompanies that of Plattorm Grace to Chevron's onshore separation and treatment and gas-processing facilities at Carpinteria in southern Santa Barbara County. Treated oil is transported (1) Chevron's 
Table 3-10. Platforms proposed to be installed in the Pacific OCS Region as of October 31, 1990

\begin{tabular}{llcccccccc}
\hline Platform & Operator & $\begin{array}{c}\text { Orlgln of } \\
\text { Jacket } \\
\text { fabrlcation }\end{array}$ & $\begin{array}{c}\text { Origln of } \\
\text { deck } \\
\text { fabrication }\end{array}$ & $\begin{array}{c}\text { Lease } \\
\text { OCS-P }\end{array}$ & UNIT/(fleld) & $\begin{array}{c}\text { Number } \\
\text { of well } \\
\text { slots }\end{array}$ & $\begin{array}{c}\text { Water } \\
\text { depth } \\
\text { (ft) }\end{array}$ & $\begin{array}{c}\text { Flrst } \\
\text { productlon }\end{array}$ \\
\hline Heritage & Exxon & Korea & Korea & 0182 & SANTA YNEZ/(Pescado) & 60 & 1,075 & 1992 \\
Heather & Exxon & $\left({ }^{\star \star}\right)$ & $\left({ }^{\star \star}\right)$ & 0193 & SANTA YNEZ/(Sacate) & 28 & 620 & $?$ \\
Julius & SWEPI & Korea & & 0409 & (San Miguel) & 70 & 478 & $?$ \\
Iris(1) & Unocal & $\left({ }^{\star \star}\right)$ & $\left({ }^{\star \star}\right)$ & 0440 & PT. PEDERNALES/ & 60 & 285 & $?$ \\
& & & & (Pt. Pedernales) & & & &
\end{tabular}

(1) Previous operator (Exxon) called it Independence.

(*) Jacket installed October 7, 1989.

(") Construction has not commenced.

El Segundo refinery in the Los Angeles area by pipeline. Cleaned sales gas is sold to SoCal Gas Company and tied into an existing SoCal line that crosses Chevron's Carpinteria facility.

On July 25, 1990, the Santa Clara Unit was contracted, relinquishing the nonproducing portions of leases within the unit. The north portion of the Santa Clara Unit includes the Santa Clara field, and platforms Gilda and Gina. The south portion of the Santa Clara Unit includes the Sockeye field and Platform Gail. The unit is operated by Chevron and includes seven leases.

\section{Cavern Point Unit}

On July 1, 1990, Chevron formed the Cavern Point Unit. The unit is composed of leases 0210 and 0527. The unit is located in the eastem Santa Barbara Channel, adjacent to the Santa Clara Units. Previously, these leases were part of the Santa Clara Unit. This unit is not currently producing.

\section{Production Phase of Postlease Activities}

As figure 3-18 (next page) indicates, annual production of crude oil and condensate from the U.S. OCS increased steadily from 1954 through 1971 when crude oil and condensate production reached its peak of $418.5 \mathrm{MMbbl}$. Following nearly a decade of decline, OCS crude oil and condensate production began to increase in 1981 and then leveled out in 1985 and 1986 at approximately $389 \mathrm{MMbbl}$ per year. Since 1985, OCS production of crude oil and condensate has declined over 21 percent to just over $305 \mathrm{MMbbl}$ in 1989.

It is important to note that the OCS still makes up over 10 percent of the total domestic crude oil and condensate production. As discussed in the introduction, the amount of crude oil the United States must import is on the rise (see fig. $I-1$, p. 4). As a result, the need for increased domestic production becomes more important. Figure 3-19 (next page) shows that the OCS contribution increased from 1954 to 1971 to a peak of 12.1 percent of all domestic crude oil and condensate production. Since 1971, the OCS contribution decreased for 9 years, as pro- 


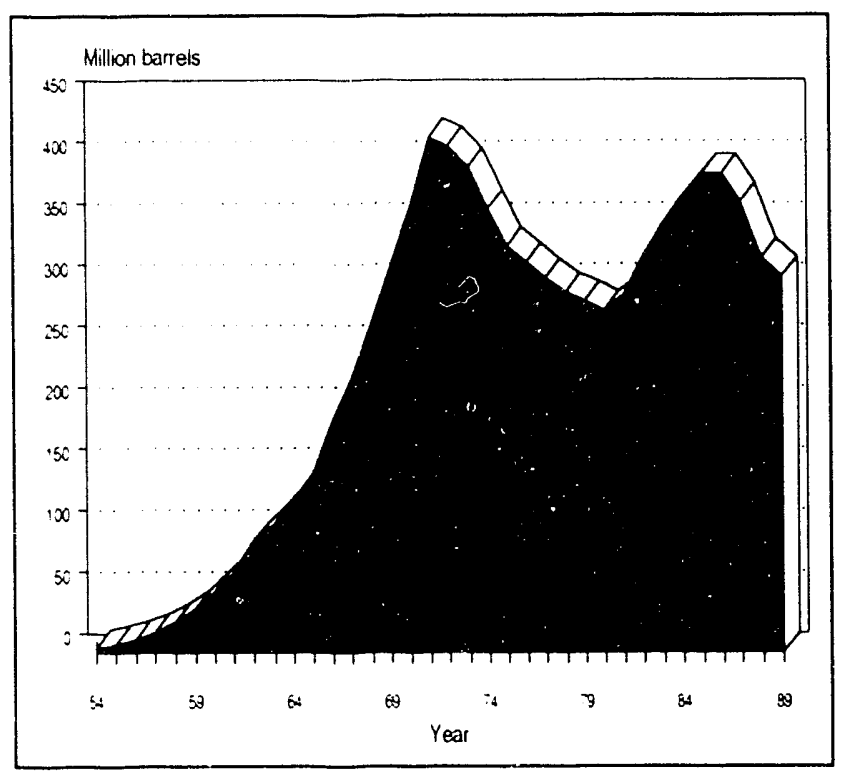

Figure 3-18. Federal offshore crude oil and condensate production, 1954-89.

duction decreased, and then in 1981 started a steady yearly increase, and peaked in 1986 at 12.3 percent. The yearly increase from 1981 to 1986 resulted from both the increase in production off the coast of California, as well as a decrease in both onshore and State offshore production. The OCS contribution fell slightly in 1987 to 12.0 percent, fell again in 1988 to 10.79 percent, and increased slightly in 1989 to 10.95 percent.

In 1989, the top 10 offshore operators produced over 76 percent of the total oil and condensate obtained from the OCS (see fig. 3-20). Chevron USA, Inc. was the top producer of oil from the OCS in 1989 , accounting for over 18 percent of the total.

As figure 3-21 (p. 127) indicates, OCS natural gas production increased steadily since 1954, and reached a peak in 1981. From 1981 to 1987, natural gas production fluctuated, and

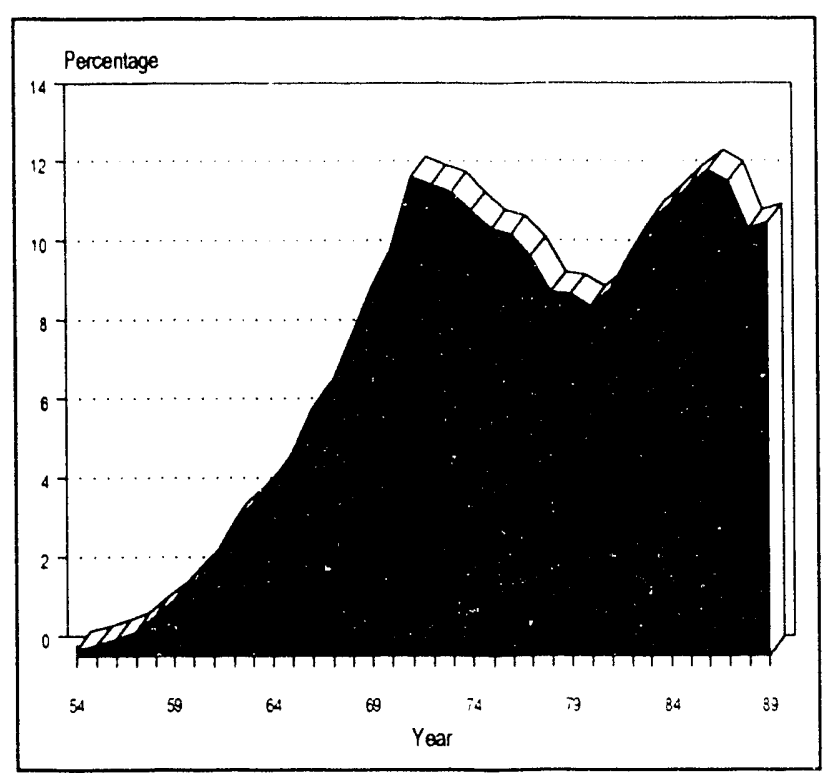

Figure 3-19. Federal offshore crude oil and condensate production as a percentage of total U.S. production, 1954-89.

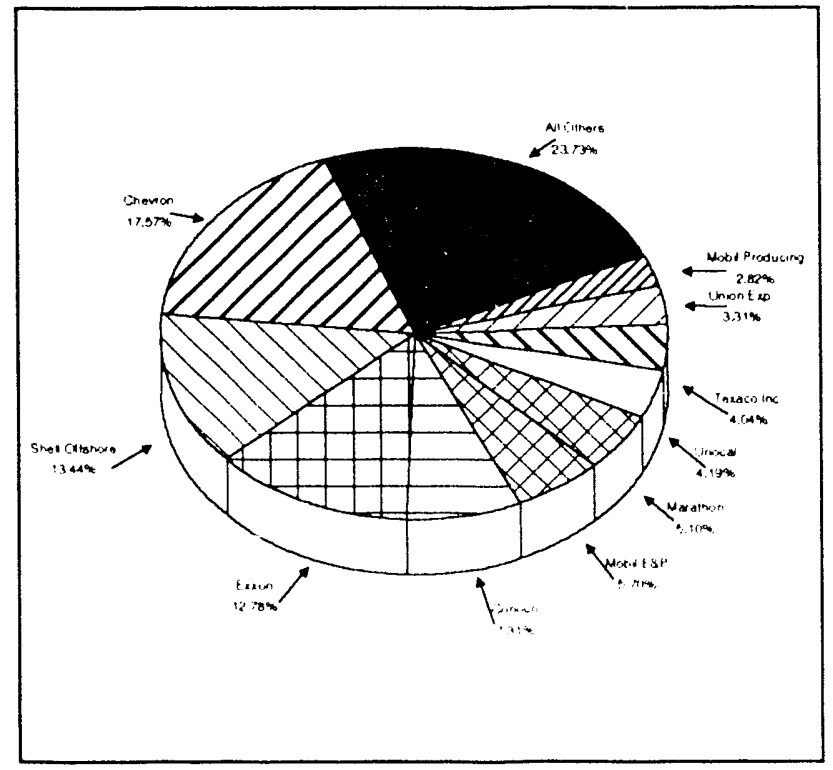

Figure 3-20. Top 10 producers by percentage of oil and condensate from the Federal OCS for 1989. 


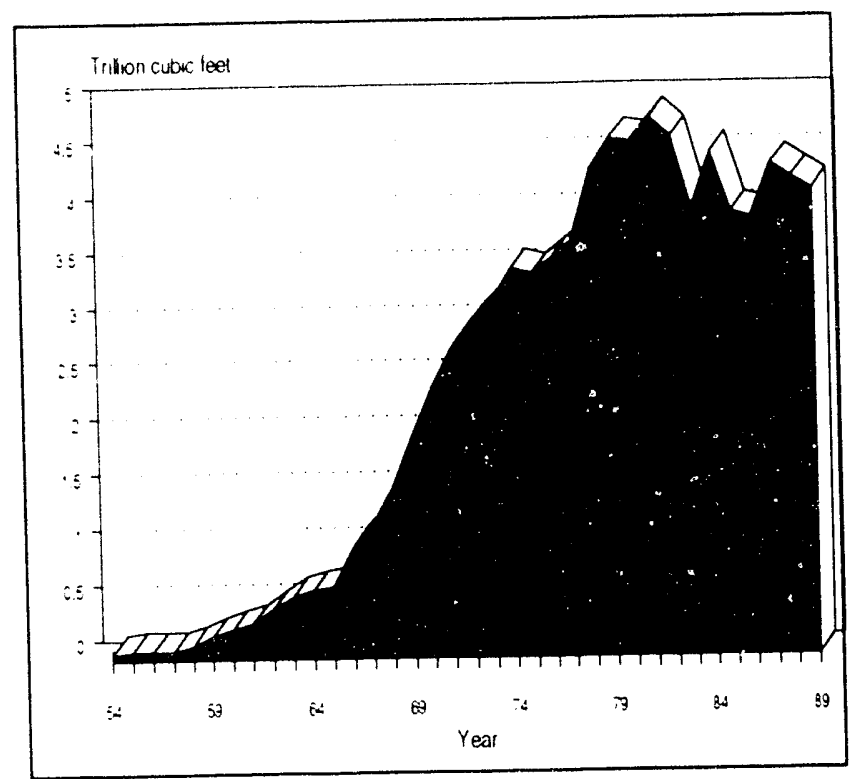

Figure 3-21. Federal offshore natural gas production, 1954-89.

since 1987, OCS natural gas production has declined. Figure $3-22$ (above) displays the percentage of the total domestic natural gas production that the Federal OCS contributed yearly. In 1987, the percentage reached an all time high, with Federal OCS natural gas production accounting for over 25 percent of the total domestic natural gas production. Since 1987. the OCS contribution has declined slightly each year to just over 23 percent in 1989. Figure 3-23 (right) displays the top 10 natural gas producers by percentage of the total Federal OCS natural gas production.

As was the case for oil, Chevron USA, Inc. was the top prolucer, accounting for 12 percent of the totial.

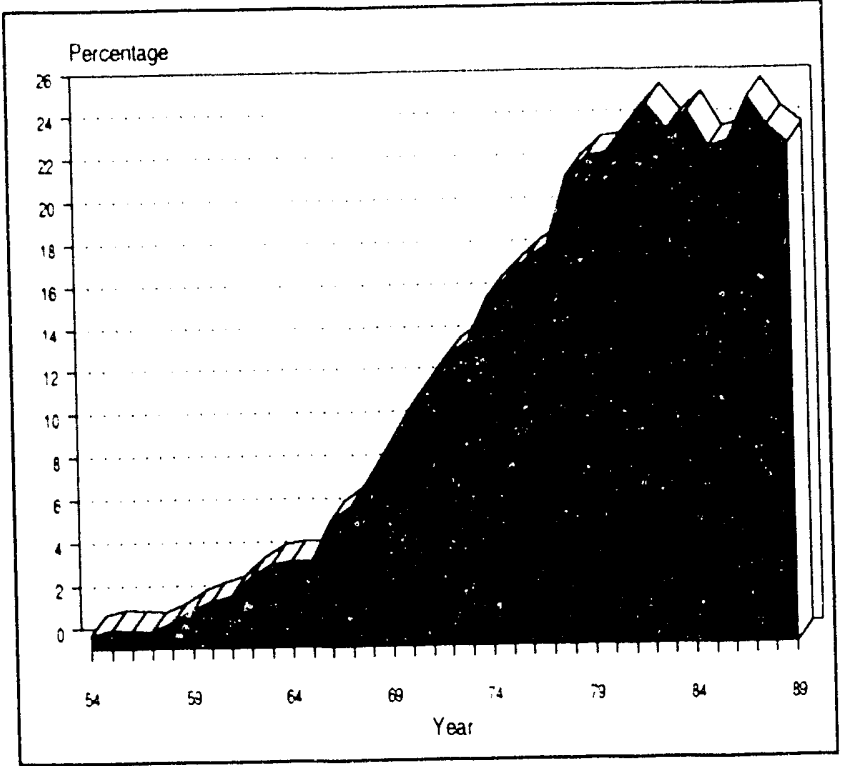

Figure 3-22. Federal offshore natural gas production as a percentage of total U.S. production, 1954-89.

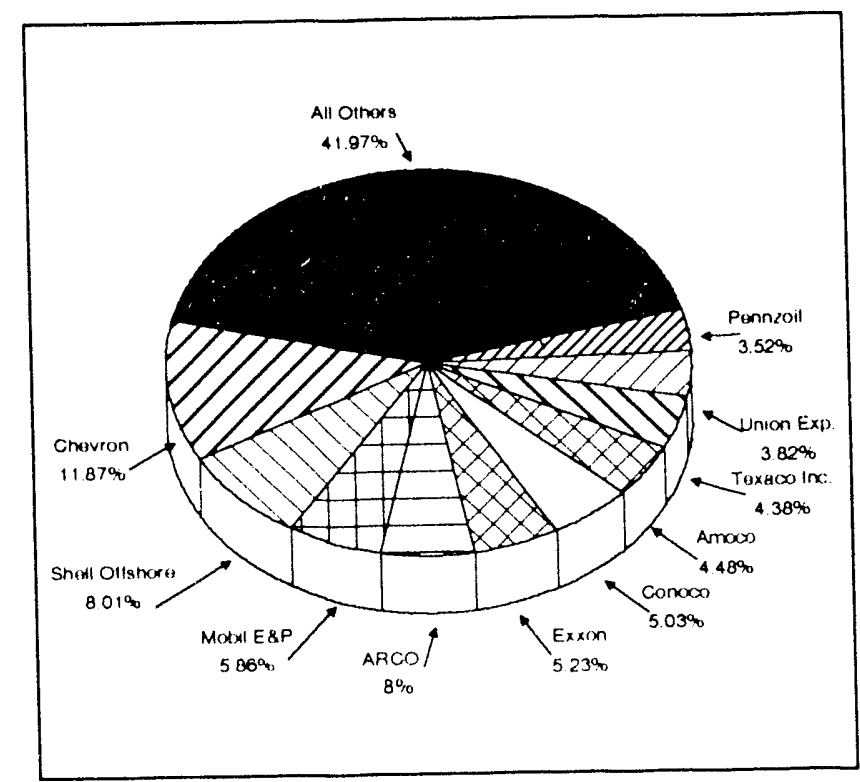

Figure 3-23. Top 10 producers by percentage of natural gas from the Federal oCS for 1989. 


\section{Gulf of Mexico OCS Region}

Production in the Gulf of Mexico OCS Region accounted for over 94 percent of the total Federal OCS production of oil, and over 99 percent of natural gas production in 1989. As figures 3-24 and 3-2.5 show, the Gulf of Mexico OCS Region was the only producing region from 1954 to 1967. In 1968, the Pacific OCS Region began to contribute to OCS production, but the Gulf of Mexico OCS has continued to account for the majority of the OCS production.

Oil and gas reserves and cumulative production at year end are shown in table 3-11 (next page) for the years 1975 through 1989. Figure 3-26 (next page) displays the number of proved fields and remaining recoverable reserves in the Central Gulf grouped by area(s); figure 3 27 (p. 130) shows the same for the Western Gulf. (See fig. 3-16, p. 115, for a map of the Gulf of Mexico OCS Region leasing maps with complete area names.)

Production from the Central Gulf of Mexico Planning Area accounts for the bulk of production in this region (see fig. 3-28, p. 130, and fig. 3-29, p. 130). As of December 31, 1989, the Central Gulf of Mexico Planning Area had produced over $7.6 \mathrm{Bbbl}$ of oil and condensate and over $76.8 \mathrm{Tcf}$ of natural gas. The Western Gulf of Mexico Planning Area had produced $229 \mathrm{MMbbl}$ of oil and condensate, and 12.1 Tcf of natural gas. No oil or natural gas has been produced from the Eastern Gulf of Mexico Planning Area.

As of December 31, 1989, there were 739 active fields in the Gulf of Mexico OCS Region. As shown in table 3-12 (p. 131), 682 of those fields were considered sufficiently developed to permit a reasonably accurate measure of reserves. Another 114 were not sufficiently developed to permit a reasonably accurate estimate of reserves; therefore, no estimates have been attempted. In addition to the 796 active fields, 57 depleted fields that were abandoned after production were included in the table in order to give a complete record of cumulative oil and

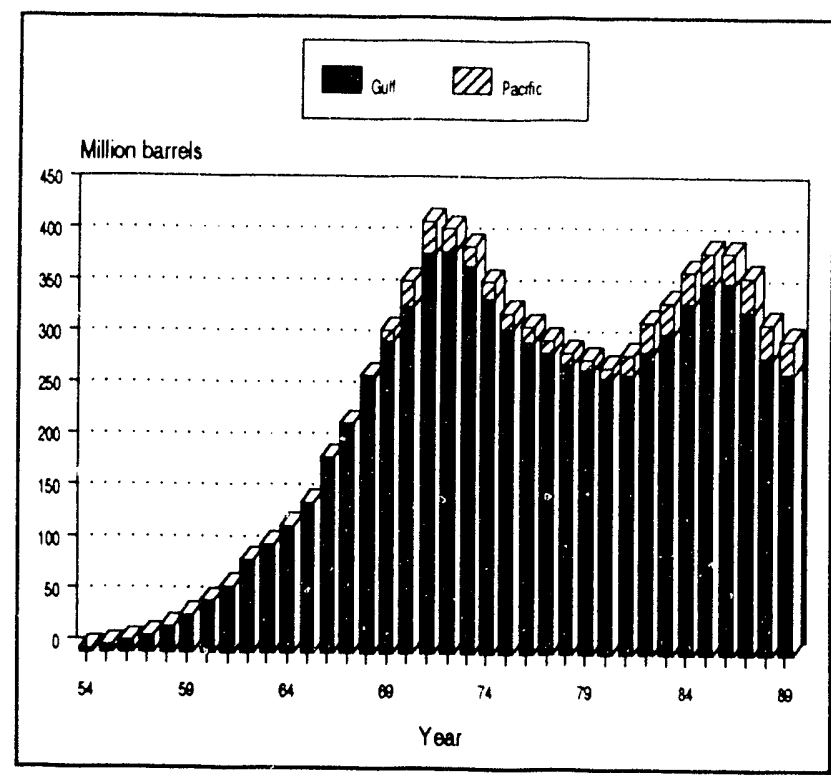

Figure 3-24. National OCS oil and condensate production, 1954-89, showing relative amounts produced in the Gulf of Mexico and Pacific OCS Regions.

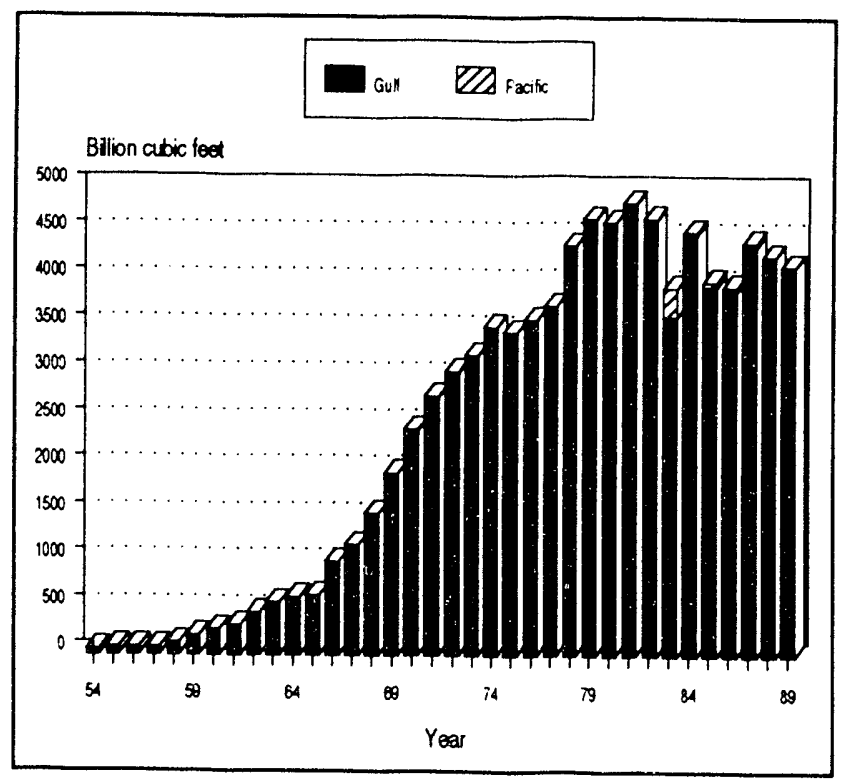

Figure 3-25. National OCS gas production, 1954-89, showing relative amounts produced in the Gulf of Mexico and Pacific OCS Regions. 
Table 3-11. Oil and gas reserves and cumulative production at end of year for the Gulf of Mexico outer continental shelf and slope, 1975-89

[Oil and BOE in billion barrels; gas in trillion cubic feet]

\begin{tabular}{|c|c|c|c|c|c|c|c|}
\hline \multirow[t]{2}{*}{ Year } & \multirow[t]{2}{*}{$\begin{array}{l}\text { No. of } \\
\text { fields }\end{array}$} & \multicolumn{2}{|c|}{$\begin{array}{c}\text { Original } \\
\text { recoverable } \\
\text { reserves }\end{array}$} & \multicolumn{2}{|c|}{$\begin{array}{l}\text { Cumulative } \\
\text { production }\end{array}$} & \multicolumn{2}{|c|}{$\begin{array}{c}\text { Remaining } \\
\text { recoverable } \\
\text { reserves }\end{array}$} \\
\hline & & Oil & Gas & Oil & Gas & Oil & Gas \\
\hline 1975 & 255 & 6.61 & 59.9 & 3.82 & 27.2 & 2.79 & 32.7 \\
\hline 1976 & 306 & 6.86 & 65.5 & 4.12 & 30.8 & 2.74 & 34.7 \\
\hline 1977 & 334 & 7.18 & 69.2 & 4.47 & 35.0 & 2.71 & 34.2 \\
\hline 1978 & 385 & 7.52 & 76.2 & 4.76 & 39.0 & 2.76 & 37.2 \\
\hline $1979^{\star}$ & 417 & 7.71 & 82.2 & 4.83 & 44.2 & 2.88 & 38.0 \\
\hline 1980 & 435 & 8.04 & 88.9 & 4.99 & 48.7 & 3.05 & 40.2 \\
\hline 1981 & 461 & 8.17 & 93.4 & 5.27 & 53.6 & 2.90 & 39.8 \\
\hline 1982 & 484 & 8.56 & 98.1 & 5.58 & 58.3 & 2.98 & 39.8 \\
\hline 1983 & 521 & 9.31 & 106.2 & 5.90 & 62.5 & 3.41 & 43.7 \\
\hline 1984 & 551 & 9.91 & 111.6 & 6.24 & 67.1 & 3.67 & 44.5 \\
\hline 1985 & 575 & 10.63 & 116.7 & 6.58 & 71.1 & 4.05 & 45.6 \\
\hline 1986 & 645 & 10.81 & 121.0 & 6.93 & 75.2 & 3.88 & 45.8 \\
\hline 1987 & 704 & 10.76 & 122.1 & 7.26 & 79.7 & 3.50 & 42.4 \\
\hline $1988^{\star \star}$ & 678 & 10.95 & 126.7 & 7.56 & 84.3 & 3.39 & 42.4 \\
\hline 1989 & 739 & 10.87 & 129.1 & 7.84 & 88.9 & 3.03 & 40.2 \\
\hline
\end{tabular}

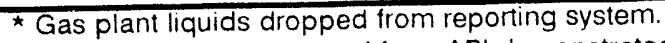

$\star \star$ Basis of reserves changed from API demonstrated to Society of Petroleum Engineers proved.

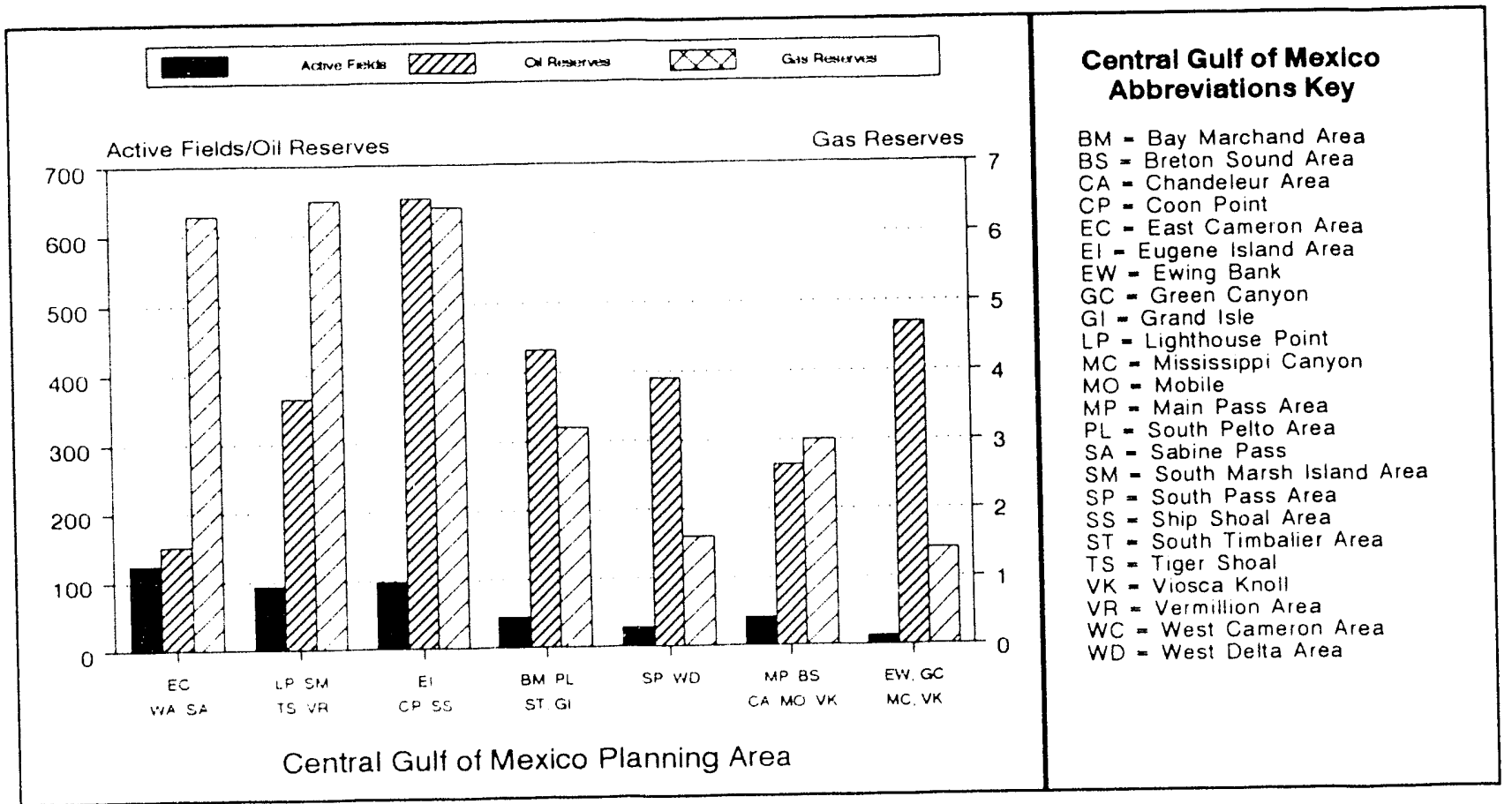

Figure 3-26. Number of proved fields and remaining recoverable reserves in the Central Gulf of Mexico, by area, as of December 31, 1989. 


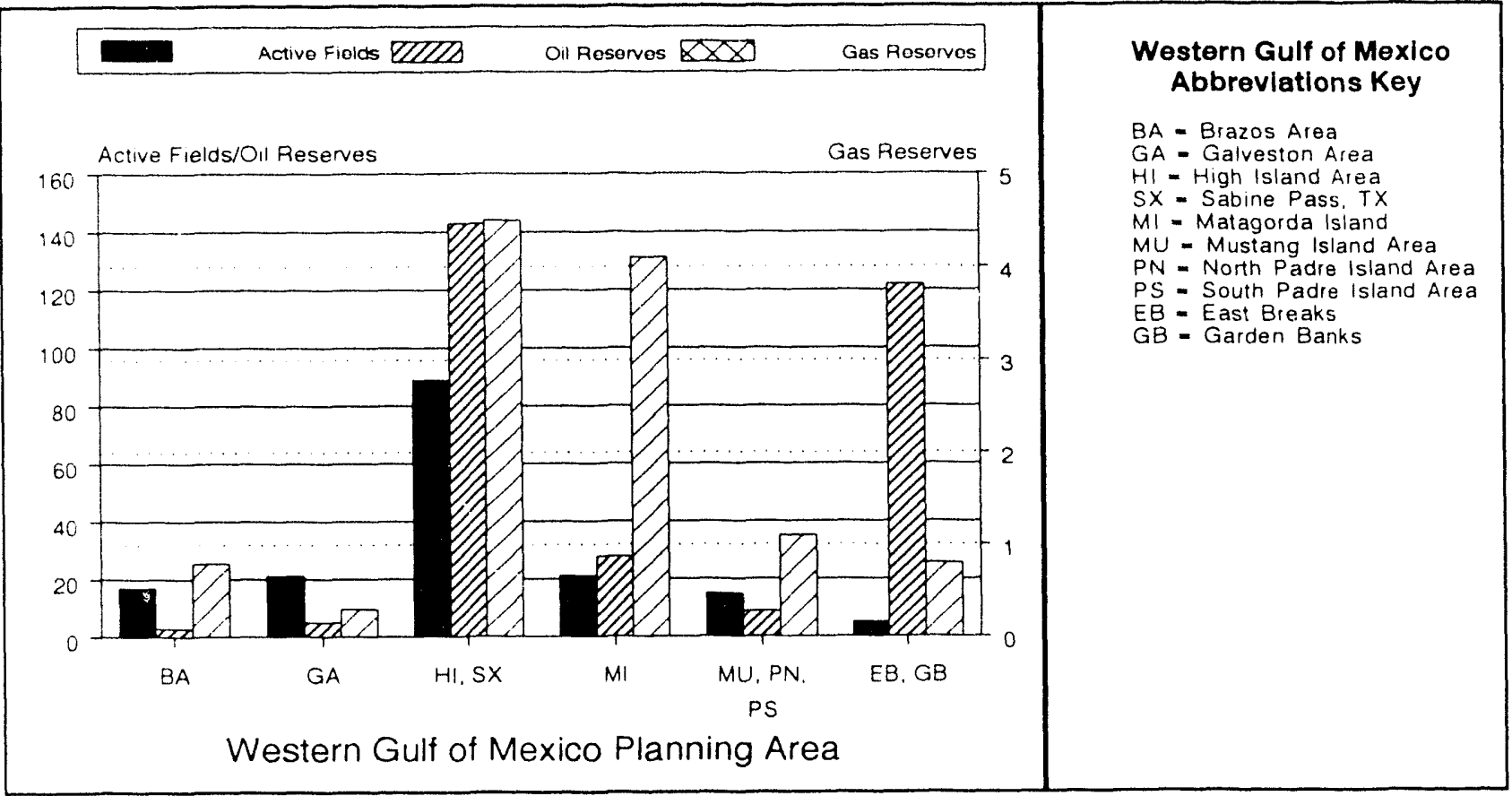

Figure 3-27. Number of proved fields and remaining recoverable reserves in the Western Gulf of Mexico, by area, as of December 31, 1989.

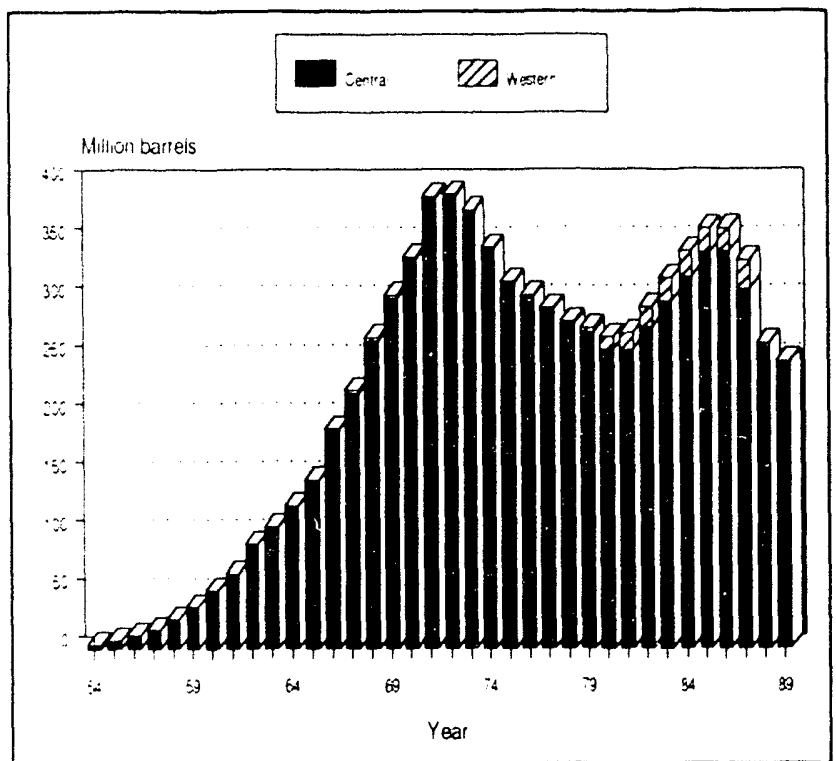

Figure 3-28. Crude oil and condensate production in the Gulf of Mexico OCS Region, 1954-89.

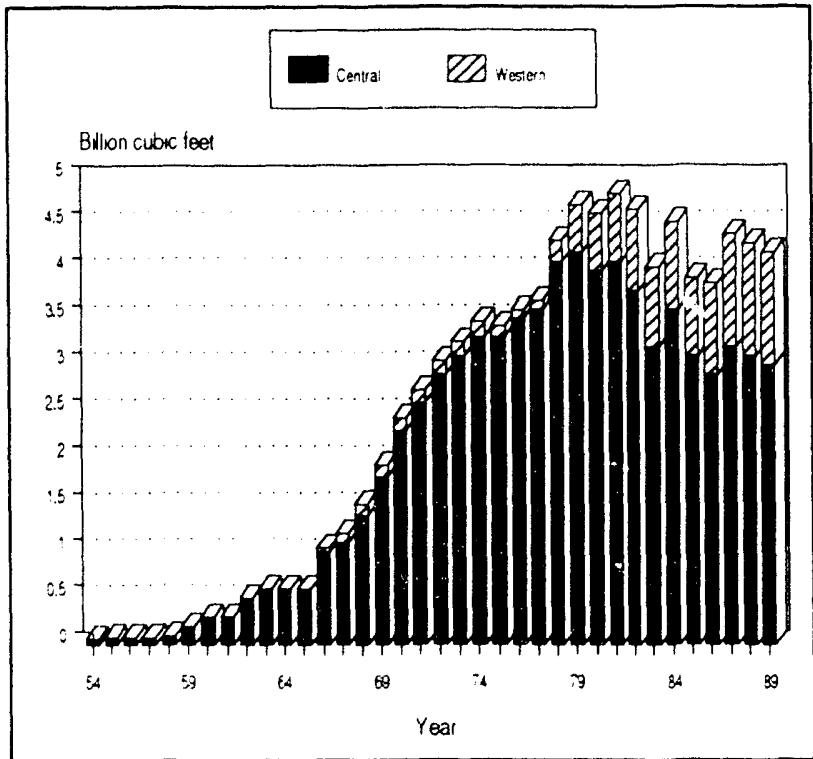

Figure 3-29. Vatural gas production in the Gulf of Mexico OCS Region, 1954-89. 
Table 3-12. Estimated demonstrated oil and gas reserves for 739 fields in the Gulf of Mexico OCS Region, by planning area, as of December 31, 1989

[Oil expressed in millions of barrels: gas in billions of cubic feet]

\begin{tabular}{|c|c|c|c|c|c|c|c|c|c|c|c|}
\hline \multirow{3}{*}{ Areas (s) } & \multirow{2}{*}{\multicolumn{3}{|c|}{$\frac{\text { Number of flelds }}{\text { Proved }}$}} & & & \multirow{2}{*}{\multicolumn{2}{|c|}{$\begin{array}{l}\text { Origlnal } \\
\text { recoverable } \\
\text { reserves }\end{array}$}} & \multirow{2}{*}{\multicolumn{2}{|c|}{$\begin{array}{l}\text { Cumulative } \\
\text { productlon } \\
\text { through } 1989\end{array}$}} & \multirow{2}{*}{\multicolumn{2}{|c|}{$\begin{array}{l}\text { Remalning } \\
\text { recoverable } \\
\text { reserves }\end{array}$}} \\
\hline & & & & \multicolumn{2}{|c|}{ Unproved } & & & & & & \\
\hline & Prod. & Non-Prod. & $\begin{array}{l}\text { Explred/ } \\
\text { Depleted }\end{array}$ & & 1989 & Oll & Gas & OII & Gas & OII & Gas \\
\hline \multicolumn{12}{|c|}{ Western Plannlng Area } \\
\hline Brazos & 17 & 3 & 4 & 2 & 0 & 8 & 2,091 & 5 & 1,210 & 3 & 881 \\
\hline Galveston & 21 & 2 & 2 & 2 & 1 & 27 & 1,181 & 22 & 855 & 5 & 326 \\
\hline \multicolumn{12}{|l|}{ High Island \& } \\
\hline Sabine Pass & 89 & 3 & 5 & 5 & 6 & 317 & 12,389 & 174 & 7.840 & 143 & 4,549 \\
\hline Matagorda Island & 21 & 6 & 0 & 1 & 1 & 35 & 5,521 & 7 & 1,419 & 28 & 4,102 \\
\hline \multicolumn{12}{|l|}{ Mustang Island \& } \\
\hline Padre Island & 15 & 4 & 3 & 3 & 0 & 11 & 1,739 & 2 & 632 & 9 & 1,107 \\
\hline Western Slope * & 5 & 1 & 0 & 9 & 1 & 141 & 966 & 19 & 135 & 122 & 831 \\
\hline Subtotal & 168 & 19 & 14 & 22 & 9 & 539 & 23,887 & 229 & 12,091 & 310 & 11,796 \\
\hline \multicolumn{12}{|c|}{$\begin{array}{l}\text { Central Planning Area } \\
\text { Chandeleur. Mobile \& }\end{array}$} \\
\hline Viosca Knoll & 6 & 20 & 0 & 14 & 0 & 1 & 1,889 & 0 & 177 & 1 & 1,712 \\
\hline East Cameron & 44 & 1 & 8 & 5 & 1 & 264 & 8,830 & 183 & 6,780 & 81 & 2,050 \\
\hline Eugene Island & 50 & 4 & 7 & 4 & 2 & 1,340 & 15,395 & 1,017 & 11,582 & 323 & 3,813 \\
\hline $\begin{array}{l}\text { Grand Isle } \\
\text { Main Pass \& }\end{array}$ & \multicolumn{10}{|c|}{ Main Pass \& } & 729 \\
\hline Breton Sound & 35 & 7 & 1 & 6 & 0 & 871 & 4,230 & 609 & 2,902 & 262 & 1,328 \\
\hline South Pelto & 6 & 0 & 1 & 0 & 0 & 132 & 707 & 94 & 458 & 38 & 249 \\
\hline South Marsh Island & 33 & 5 & 4 & 2 & 1 & 782 & 12,048 & 563 & 9.064 & 219 & 2,984 \\
\hline South Pass & 10 & 1 & 0 & 2 & 0 & 935 & 2,817 & 699 & 2,045 & 236 & 772 \\
\hline Ship Shoal & 47 & 4 & 4 & 4 & 2 & 1,248 & 10,561 & 918 & 8,000 & 330 & 2,561 \\
\hline South Timbalier & 29 & 4 & 1 & 5 & 2 & $i, 302$ & 6,950 & 1,059 & 4,731 & 243 & 2,219 \\
\hline Vermillion & 60 & 3 & 5 & 4 & 2 & 474 & 14,781 & 329 & 11,287 & 145 & 3,494 \\
\hline \multicolumn{12}{|l|}{ West Cameron \& } \\
\hline Sabine Pass & 80 & 2 & 8 & 5 & 4 & 185 & 16,488 & 115 & 12,253 & 70 & 4,235 \\
\hline West Delta & 17 & 1 & 1 & 3 & 0 & 1,201 & 4,395 & 1,047 & 3.585 & 154 & 810 \\
\hline Central Slope $e^{\star \star}$ & 12 & 3 & 0 & 33 & 7 & 678 & 2,203 & 209 & 776 & 469 & 1,427 \\
\hline Subtotal & 439 & 55 & 43 & 89 & 21 & 10,335 & 105,211 & 7,614 & 76,828 & 2,721 & 28,383 \\
\hline \multicolumn{12}{|c|}{ Eastern Planning Area $\star \star \star$} \\
\hline Subtotal & 0 & 1 & 0 & 3 & 0 & 0 & 0 & 0 & 0 & 0 & 0 \\
\hline $\begin{array}{c}\text { Subtotal } \\
\text { Total }\end{array}$ & 607 & $\frac{75}{739}$ & 57 & 114 & 30 & 10,874 & 129,098 & 7,843 & 88,919 & 3,031 & 40,179 \\
\hline
\end{tabular}

"Western Slope includes Alaminos Canyon, Corpus Christi, East Breaks, Garden Banks, Keathiey Canyon. and Port!sabel.

" Central Slope includes Atwater Valley, Ewing Eank. Green Canyon, Mississippi Canyon, Viosca Knoll (slope) and Walker Riage.

* Eastern Planning Area inciudes Crartotte Harvor. Destin Dome, Pensacola, Pulley Ridge andothers.

gas production. As has been the case for decades, the Central Gult of Mexico Planning Area has the majority of the region's fields, 90 percent of the remaining recoverable oil reserves, and 71 pereent of the remaining recovcrable gas reserves. 


\section{Pacific OCS Region}

Production in the Pacific OCS Region began in 1968 when Platform Hogan began producing oil from the Carpinteria Offshore field. As table 3-9 (p. 119) showed, 21 production platforms have been installed in the Southern California Planning Area. As of December 31, 1989, production from these platforms has totaled over $468 \mathrm{MMbbl}$ of oil and approximately $346 \mathrm{Bcf}$ of natural gas. See table 3-1 on the next page for more information.

As shown on figure 3-30 (next page), annual production of crude oil in the Pacific OCS Region increased rapidly from 1968 to 1971, when production exceeded $31 \mathrm{MMbbl}$ of oil per year. Production of oil then declined until 1980, when Platform Grace in the Santa Clara field and Platform Henry in the Carpinteria field began producing. In 1981, Pacific OCS crude oil production increased over 92 percent from 1980, as Platform Hondo (in the Santa Ynez Unit), Platform Gilda (in the Santa Clara Unit) and Platform Ellen (in the Beta Unit) were brought on line. (See Unitization sidebar for more information.) Annual production continued to increase from 1980, to a record level of over $33.5 \mathrm{MMbbl}$ in 1987 . In 1988, production declined to $32.6 \mathrm{MMbbl}$ and then rebounded in 1989 to $33.1 \mathrm{MMbbl}$.

Natural gas production on the Pacific OCS rose steadily from 1968 through 1971 and then went through a period of decline until it leveled off in 1975 (see fig. 3-31 on the next page). From 1975 through 1980, natural gas production on the Pacific OCS remained fairly constant at approximately $3.5 \mathrm{Tcf}$ per year. As a result of production from Hondo and Santa Clara fields, production increased over 310 percent from 1980 to 1981 , and then, following a slight decrease in 1983, natural gas production in the Pacific increased to a record level of 49.2 Tcf in 1985. This increase was caused, in part, by initial production from Platforms Edith and Eurcka in the Beta Unit. Since 1985, natural gas production has been on the decline. In 1989, gas production on the Pacific OCS was 28.6 Bcf.

\section{Unitization}

Unitization is the practice of pooling all interests, ownership, and control in a producing field or part of a field to ensure conservation of natural resources and to protect correlative rights in the national interest. A unit agreement provides for a single operator or company to develop and operate several leases as if they were one. The purpose of the agreement is to maximize oil and gas recovery from reservoirs with multiple owners, while eliminating the drilling of unnecessary wells, reducing development and production costs, and ensuring the orderly development of petroleum resources as well as the equitable distribution of revenues to all owners of correlative rights.

As part of its supervisory role in the OCS production process, MMS encourages voluntary unitization. When operators fail to enter into unit agreements voluntarily, MMS may initiate the formation of units where it is deemed necessary for conservation and protection of public resources. Once a unit has been formed, an operator of a lease within the unit can request a suspension of operations from MMS. If a suspension is granted, the term of the lease can be extended beyond its primary term for a period of time specified by the suspension agreement.

Table 3-14 (p. 134) lists the original reserves, cumulative production, and the remaining reserves for the 37 fields that MMS identified as producible in the Pacific OCS Region as of December 31,1989 . Note that this is an increase of 13 fields from the previous year and is attributed to the evaluation of wells analyzed subsequent to the change in reserves definitions and determined to have tested unproved possible oil reserves. Of the total of 37 fields, 13 have been determined to have proved reserves of oil and gas, and 24 were determined to have unproven reserves of oil and gas. Nine fields were producing as of December 31, 1989. Figure 3-32 (p. 135) displays the locations of these fields. 
Table 3-13. Pacific OCS Region's contribution to national production, 1968-89

\begin{tabular}{|c|c|c|c|c|c|c|c|c|c|}
\hline \multirow[b]{2}{*}{ Year } & \multicolumn{4}{|c|}{ Oll and Condensate (bbl) } & \multicolumn{4}{|c|}{ Natural Gas (Mcf) } & \multirow[b]{2}{*}{ Year } \\
\hline & $\begin{array}{l}\text { Natlonal } \\
\text { OCS } \\
\text { productlon }\end{array}$ & $\begin{array}{l}\text { Callfornia } \\
\text { OCS } \\
\text { production }\end{array}$ & $\begin{array}{c}\text { Percent } \\
\text { of } \\
\text { natlonal }\end{array}$ & $\begin{array}{l}\text { Production } \\
\text { change } \\
(+/-)(*)\end{array}$ & $\begin{array}{c}\text { National } \\
\text { OCS } \\
\text { production }\end{array}$ & $\begin{array}{l}\text { Callfornia } \\
\text { OCS } \\
\text { production }\end{array}$ & $\begin{array}{c}\text { Percent } \\
\text { of } \\
\text { natlonal } \\
\end{array}$ & $\begin{array}{l}\text { Production } \\
\text { change } \\
(+/-)\left({ }^{\star}\right)\end{array}$ & \\
\hline $1968(1)$ & $268,995,890$ & $2,059,889$ & 0.77 & & $1,524,178,078$ & 799,685 & 0.05 & & (1) 1968 \\
\hline $1969(2)$ & $312,859,987$ & $9,940,844$ & 3.18 & 382.59 & $1,954,486,975$ & $4,845,851$ & 0.25 & 505.97 & (2) 1969 \\
\hline $1970(3)$ & $360,646,168$ & $24,987,628$ & 6.93 & 151.36 & $2,418,676,591$ & $12,229,147$ & 0.51 & 152.36 & (3) 1970 \\
\hline 1971 & $418,548,946$ & $31,103,548$ & 7.43 & 24.48 & $2,777,043,418$ & $15,671,479$ & 0.56 & 28.15 & 1971 \\
\hline 1972 & $411,885,893$ & $22,562,213$ & 5.48 & -27.46 & $3,038,554,773$ & $10,033,581$ & 0.33 & -35.98 & 1972 \\
\hline 1973 & $394,729,999$ & $18,915,314$ & 4.79 & -16.16 & $3,211,588,422$ & $7,286,549$ & 0.23 & -27.38 & 1973 \\
\hline 1974 & $360,594,065$ & $16,776,744$ & 4.65 & -11.31 & $3,514,723,907$ & $5,573,642$ & 0.16 & -23.51 & 1974 \\
\hline 1975 & $330,237,452$ & $15,304,757$ & 4.63 & -8.77 & $3,458,693,454$ & $3,951,633$ & 0.11 & -29.10 & 1975 \\
\hline 1976 & $316,920,109$ & $13,978,553$ & 4.41 & -8.67 & $3,595,923,526$ & $3,475,201$ & 0.10 & -12.06 & 1976 \\
\hline $1977(4)$ & $303,948,240$ & $12,267,598$ & 4.04 & -12.24 & $3,737,746,922$ & $3,289,963$ & 0.09 & -5.33 & (4) 1977 \\
\hline 1978 & $292,265,042$ & $12,085,908$ & 4.14 & -1.48 & $4,385,060,878$ & $3,472,292$ & 0.08 & 5.54 & 1978 \\
\hline 1979 & $285,565,538$ & $10,961,076$ & 3.84 & -9.31 & $4,672,979,139$ & $2,866,822$ & 0.06 & -17.44 & 1979 \\
\hline $1980(5)$ & $277,388,975$ & $10,198,886$ & 3.68 & -6.95 & $4,641,456,983$ & $3,107,023$ & 0.07 & 8.38 & (5) 1980 \\
\hline $1981(6)$ & $289,765,405$ & $19,605,027$ & 6.77 & 92.23 & $4,8 \Delta 9,536,728$ & $12,766,307$ & 0.26 & 310.89 & (6) 1981 \\
\hline $1982(7)$ & $321,211,457$ & $28,434,202$ & 8.85 & 45.04 & $45,79,511,272$ & $17,750,924$ & 0.38 & 39.05 & (7) 1982 \\
\hline $1983(8)$ & $348,331,243$ & $30,527,487$ & 8.76 & 7.36 & $4,040,733,857$ & $16,024,292$ & 0.40 & -9.73 & (8) 1983 \\
\hline $1984(9)$ & $370,239,014$ & $30,254,306$ & 8.17 & -0.89 & $4,537,841,051$ & $27,806,899$ & 0.61 & 73.53 & (9) 1984 \\
\hline $1985(10)$ & $386,324,285$ & $29,781,465$ & 7.71 & -1.56 & $4,000,975,226$ & $49,164,213$ & 1.23 & 76.81 & (10) 1985 \\
\hline 1986 & $389,216,002$ & $29,227,846$ & 7.51 & -1.86 & $3,948,895,001$ & $42,689,021$ & 1.08 & -13.17 & 1986 \\
\hline $1987(11)$ & $366,141,709$ & $33,556,686$ & 9.16 & 14.81 & $4,425,581,690$ & $40,986,158$ & 0.93 & -3.99 & (11) 1987 \\
\hline 1988 & $320,667,424$ & $32,615,118$ & 10.17 & -2.81 & $4,309,874,827$ & $34,570,638$ & 0.80 & -15.65 & 1988 \\
\hline 1989 & $305,167,655$ & $33,072,161$ & 10.84 & 1.40 & $4,200,263,926$ & $28.574,912$ & 0.68 & -17.34 & 1989 \\
\hline Totals & $7,431,650,498$ & $468,217,256$ & 6.30 & & $81,924,326,644$ & $346,936,232$ & 0.42 & & \\
\hline $\begin{array}{l}\text { (1) Initial pro } \\
\text { (2) Initial pro } \\
\text { (3) Initial pro } \\
\text { (4) Initial pro } \\
\text { (5) Initial pro } \\
\text { (4) Increase o }\end{array}$ & $\begin{array}{l}\text { oduction: Platform } \\
\text { oduction: Platform } \\
\text { oduction: Platform } \\
\text { oduction: Platform } \\
\text { oduction: Platform } \\
\text { or decrease from o }\end{array}$ & $\begin{array}{l}\text { Hogan } \\
\text { s Houchin and } A \\
\text { s Hillhouse and } B \\
C \\
\text { s Henry and Grace } \\
\text { evious year. }\end{array}$ & & $\begin{array}{l}\text { (6) Initial proo } \\
\text { (7) Initial proc } \\
\text { (8) Initial proo } \\
\text { (9) Initial proc } \\
\text { (10) Initial pro } \\
\text { (11) Initial pro }\end{array}$ & $\begin{array}{l}\text { iction: Platforms Hor } \\
\text { iction: Platform Gina } \\
\text { iction: Platform Habi } \\
\text { iction: Platform Edit } \\
\text { uction: Platform Eur } \\
\text { uction: Platform Iren }\end{array}$ & $\begin{array}{l}\text { ido, Eilen, and } G_{1} \\
\text { tat } \\
\text { eka } \\
\text { e }\end{array}$ & & & \\
\hline
\end{tabular}

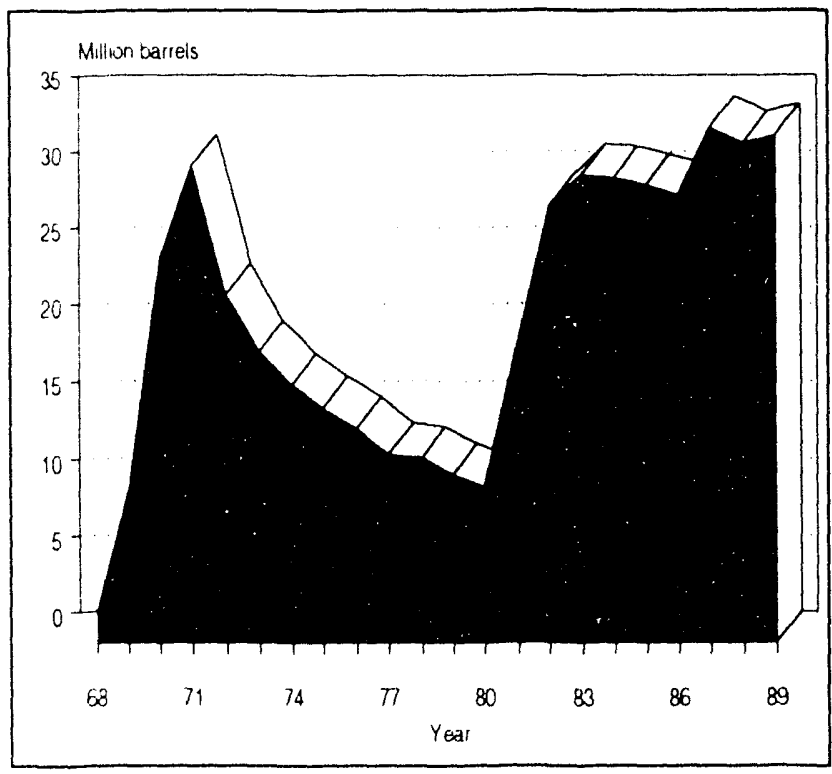

Figure 3-30. Crude oil production in the Pacific OCS Region, 1968-89.

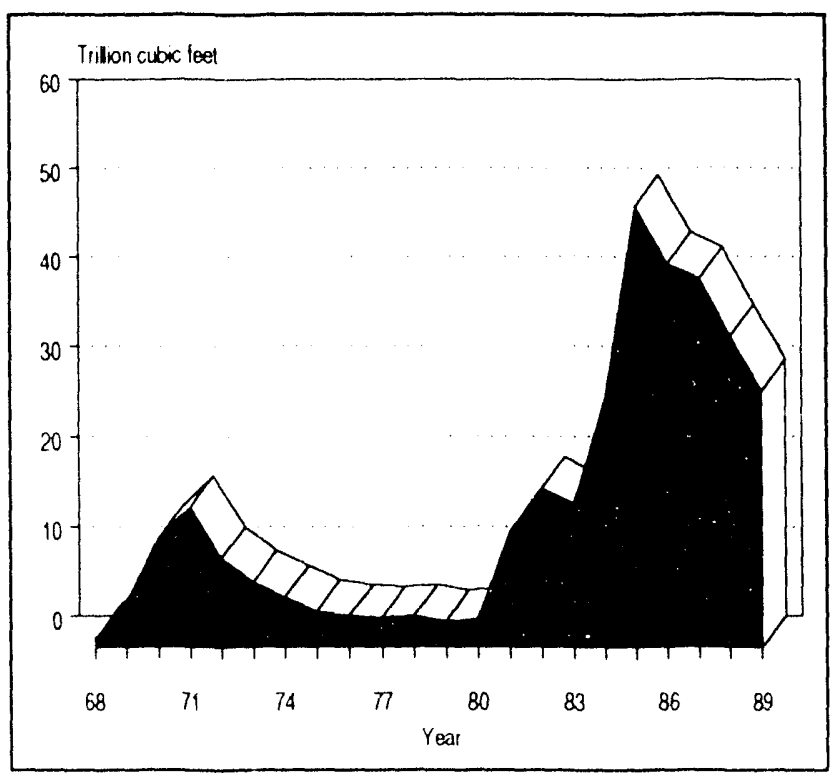

Figure 3-31. Natural gas production in the Pacific OCS Region, 1968-89. 
Table 3-14. Estimated annual oil and gas reserves and cumulative production for the Pacific OCS Region, 1982-89

[Oil in million barrels; gas in billion cubic feet]

\begin{tabular}{|c|c|c|c|c|c|c|c|c|}
\hline Federal data & 1982 & 1983 & 1984 & 1985 & 1986 & 1987 & 1988 & $1989^{\star}$ \\
\hline Number of fields & 14 & 20 & 23 & 24 & 24 & 24 & 24 & 37 \\
\hline \multicolumn{9}{|c|}{ Original reserves(1) } \\
\hline Oil(2) & 1,217 & 1,433 & 1,515 & 1,599 & 1,670 & 1,727 & 1,729 & 1,987 \\
\hline Gas(2) & 1,983 & 2,298 & 2,400 & 2,334 & 2,461 & 2,501 & 2,467 & 2,723 \\
\hline \multicolumn{9}{|l|}{ Annual production } \\
\hline Oil & 28 & 31 & 31 & 30 & 29 & 31 & 32 & 33.1 \\
\hline Gas & 18 & 24 & 46 & 64 & 58 & 55 & 49 & 50.9 \\
\hline \multicolumn{9}{|c|}{ Cumulative production } \\
\hline Oil & 249 & 280 & 310 & 340 & 369 & 400 & 431 & 464.5 \\
\hline Gas & 132 & 156 & 202 & 265 & 323 & 378 & 427 & 477.9 \\
\hline \multicolumn{9}{|c|}{ Remaining reserves(1) } \\
\hline Oil & 968 & 1,153 & 1,205 & 1,259 & 1,302 & 1,328 & 1,298 & 951 \\
\hline Gas & 1,851 & 2,141 & 2,198 & 2,069 & 2,135 & 2,123 & 2,040 & 1,515 \\
\hline \multicolumn{9}{|c|}{ 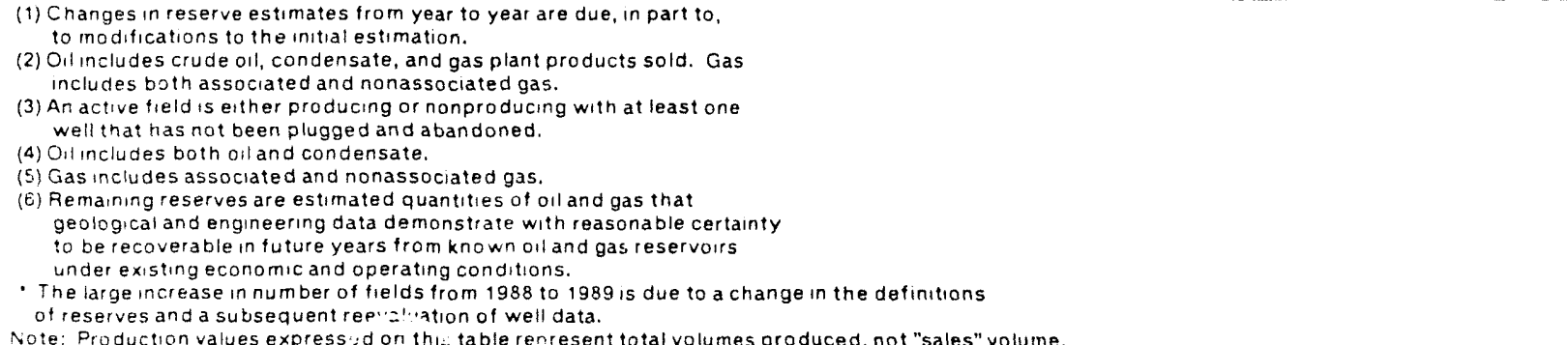 } \\
\hline
\end{tabular}

\section{Additional Reading}

Huth, (ium 1. Suarls, Anthon W. 1990. Fstimated (lil and cias Re'se's es las of Dece'mber 31, 1989). OCS Information Report MMS y()-(0)8s6. $18 \mathrm{p}$.

Kirputi, K.M. and Gould, (j.I. 1990). Allamic Update: July lys(-.June /yge oCS information Report MMS (4)-(1)(0), $57 \mathrm{p}$

Mencrals Management Service. August 19y0. Final linvironmental keport on Proposed Exploratory Drilling

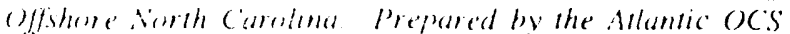
kesum. ; wh

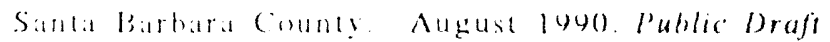

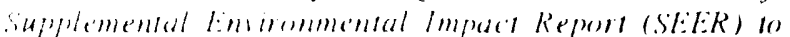

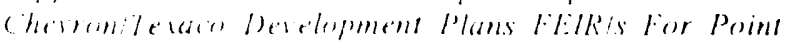

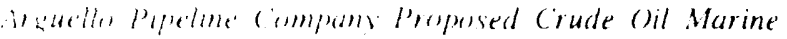

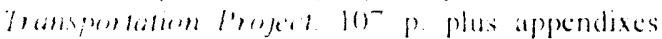




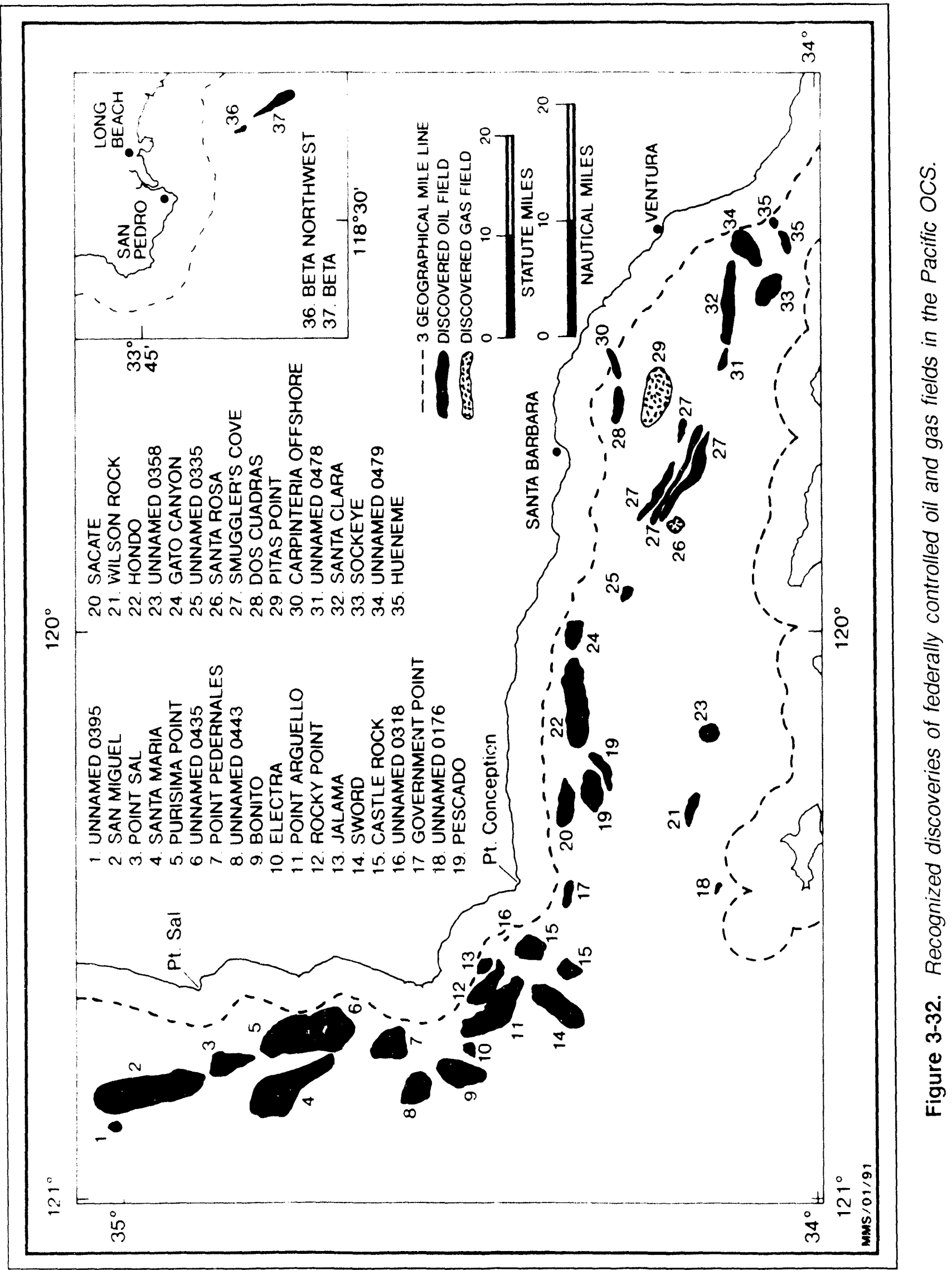




\section{Oil and Gas Transportation and Onshore Support Facilities}

\section{Oil and Gas Transportation}

Offshore oil and gas can be transported to shore via pipelines, barges, or tunkers. The choice between these different modes of transportation depends on a number of factors. including size and composition of the offshore field: the field's distance from shore: weather and oceanographic conditions; proximity to refineries and processing plants; and whether or not onshore pipelines exist to transport the product to a processing facility. These factors may be compounded by permitting problems. which can strongly influence onshore facilities.

Most of the oil and gas produced off shore undergoses preliminary separation, treatment. and metering at the platform, and is then transported to shore for final processing and refining. The majority of OCS hydrocarbons are tramported to shore via pipeline: the balance is carried on barges or tankers.

A number of agencies have varying degrees of authority in approving transportation plans for routing pipelines. The $M M 1 \mathrm{~S}$ is responsible for 11 , issuing pipeline permits, (2) approving pipeline rights-of-way for transport of oil and gas through waters under Federal jurisdiction, and (3) inspecting and monitoring pipelines. Agencies involved in approval or review of these pipelines include the L.S. Army Corps of Engineer, the Federal Energy Regulatury Commission, the Interstate Commerce Commission, and the Department of Transportation's Ottice of Pipeline Safety. In State waters, pipeline right-of-ways and permitting for site lecations if coatul-dependent, energy-related facilities. such as pipeline landfalls, marine terminals, and service support bases, are the responsibilit: uf the respective State authorities.

\section{Port Access Route Studies}

The U.S. Coast Guard (USCG) regularly conducts Port Access Route Studics (PARS). The siudies examine potential vessel traffic density in, and the safety of existing or pioposed access routes in traffic separation schemes (TSS), in tairways, or in precautionary areas adjoining major ports. Implementing the findings of these studies affect the manner in which specific OCS areas are leased and subsequently explored or developed. These studies are conducted in all of the OCS regions. Some examples are provided below.

On September 20. 198x, the USCG published a final rule (33 (FR Part 166) in the Federal Register (53 FR 36453) that adjusts a portion of the western boundary of the Mobile Ship Channel Safety Fairway in the approach to Mohile. Alabama. The adjustment was reyuired wo free a purtion of a Federal lease block from fairway structure restrictions. A port access route study. conducted by the USCG, concluded that the adjustment is necessary and can be made without adversely affecting the purpose for which the fairway was established.

On April 27. 1989. the USCG published in the Federal Register a proposed rule that proposes to establish a routing system composed of amended TSS's and new shipping safety fairways along the coust of Califomia. This proposed rule was developed as a result of a number of PARS that the USCG mitiated on April 16. 1979 (4t FR 22543) and completed on May $x$. 1986 151 FR 170171). The proponed rule will modify the existing TSS's in the approaches (1) San Francisco, in the Santa Barbara Channel. and in the approaches to the ports of Los Angeles Long Beach. It will atow establish new shipping ately tairways conmecting the San Francioco TSS and the Santa Barbara Channel TSS averly ing the precauten- 
ary areas in the approaches to Los AngelesiLong Beach and San Francisco. The USCG stated that the proposed routing measures will increase navigation safety by separating opposing vessel traffic and by preserving a right of navigation through areas which are now, or will be, sites of oftshore oil and gas development. For more information on USCG PARS, contact Margie G. Hegy, Project Managei, Short Range Aids to Navigation Division at (202) 267-0415.

Regional overviews of OCS transportation are provided below. Although there is no production in the Alaska and Atlantic regions, a number of transportation plans have been developed for these regions.

\section{Regional Transportation Overviews}

\section{Alaska OCS Region}

When the OCS Oil and Gas Leasing Program began in Alaska during the 1970\%, transportation strategies and issues were studied caretul'y to assess the impacts of various scenarios. The Aluskiu environment creates many challenges for plinners and engineers, such as sea ice, permatrost. earthquakes, and volcanoes. Hydrocarbon transportation systems were studied to udiress each of these unique environmental considerations. These studies and discussions led to proposals for the transportation of Alaska OCS oil and gas from offshore wellheads to shoreside transshipment facilities and from those facilities to major refineries and murkets

A mujor component of MMS's research and plunning activities in the region has been the Alasku OCS Social and Economic Studies Progrum (SESP). The multiyear SESP research effort is assessing and evaluating the effects of OCS devalopment upon the cultural, social, and coonomic environments within the State of Aluskit.

Nany other studies of possible transportatun scenarios tor Alaska OCS hydrocarbons have been conducted, as have many studies that have produced related findings. Examples of such studies would include reports of the $\mathrm{Na}$ tional Petroleum Council's Transportation Task Group on east-west pipelines to connect Bering Sea coastal landfalls into the Alyeskia pipeline and the voyage of the Exxon ice-breaking tanker Manhattan across the northwest passage to the Atlantic Ocean. For more information on studies related to Alaska OCS transportation, contact the following office:

Environmental Studies Section

Minerals Management Service

Alaska OCS Region

949 East 36th Ave., Room 110

Anchorage, AK 99508

Although no development has occurred to date on the Alaska OCS, the studies conducted on a wide variety of possible transportation systems have defined probable scenarios for each planning area. Table 4-1 (p. 139) provides an overview of the various Alaska OCS oil and gas transportation strategies. In each case, hydrocarbons are transported to a transshipment facility on an Aleutian island, on the southern coast of the Alaska Peninsula, or along the shore of the Gulf of Alaska. From this facility in an ice-free port, oil would be loaded onto very large crude carriers (VLCC's) or other large tankers for shipment to continental U.S. refineries and marketing centers. The operation would be similar in this stage to the Alyeska transshipment faciity activities in Valdez (i.e., loading oil from the Trans-Alaska Pipeline onto U.S. tankers headed for the conterminous States).

In all the scenarios except for that of Navarin Basin hydrocarbons, pipelines from of fshore production platforms to onshore facilities are considered the preferred method for transportation to shore. The Federal Government has made this preference clear in stipulations attached to OCS leases in the Beautort Sea. Norton Basin, St. George Basin, Cook Inlet, and Gulf of Alaska Planning Areas. ISee the Transportation of Hydrocarbon Products Silpulation for Alaska OCS Leases sidebar on p. 14(1.) 
Table 4-1. Transportation scenarios for hydrocarbons produced from Alaska OCS planning areas

\begin{tabular}{ll}
\hline Planning area & Transportation scenario \\
\hline Beauiort Sea & $\begin{array}{l}\text { Marine pipelines to landfall, onshore pipeline to connection with Trans-Alaska Pipeline or natural gas } \\
\text { pipeline system for transport to transshipment facility on coast of the Gulf of Alaska. }\end{array}$ \\
Norton Basin & $\begin{array}{l}\text { Marine pipeline to onshore storage and loading facility, ice-breaking shuttle tankers to transshipment } \\
\text { facility on south side of the Alaska Peninsula or Aleutian Islands. }\end{array}$ \\
St. George Basin & $\begin{array}{l}\text { Marine pipeline to an onshore transshipment facility on one of the Pribilof !slands (for production } \\
\text { sites in northern section of basin). }\end{array}$ \\
& $\begin{array}{l}\text { Marine pipeline to landfall, onshore pipeline to transshipment facility on south side of an Aleutian } \\
\text { Island. }\end{array}$ \\
Navarin Basin & $\begin{array}{l}\text { Marine pipeline to adjacent offshore loading facility, ice-breakli, shuttle tankers to transshipment } \\
\text { facility on a Pribilof or Aleutian Island. }\end{array}$ \\
Cook Inlet & $\begin{array}{l}\text { Marine pipeline to onshore transshipment facility on coast of Cook Inlet or Gulf of Alaska. } \\
\text { Gulf of Alaska }\end{array}$ \\
North Aleutian Basin & $\begin{array}{l}\text { Marine pipeline to onshore transshipment facility on coast of the Gulf of Alaska. } \\
\text { Marine pipeline to landfall, onshore pipeline to transshipment facility on south side of an Aleutian } \\
\text { Island. } \\
\text { Marine pipeline to landfall near Point Belcher, onshore pipeline to connect with Trans-Alaska } \\
\text { Pipeline at Pump Station 2. }\end{array}$
\end{tabular}

The distance of the Navarin Basin from any landfalls precludes the economic benefit of pipelines to shore. Nevertheless, in a Navarin Basin production scenario, wellheads would be so distant from onshore locations that risks to coastal zone environments would be minimized. Therefore, the transportation scenario for the Navarin Basin would include using tankers to transport the hydrocarbons to shore.

\section{Atlantic OCS Region}

Transportation issues were examined in each of the four planning areas. The EIS's generated for each lease sale within these areas recognize a number of conceivable gas pipeline corridors and oil tanker routes. However. because no commercially producible quantities of oil and gas have been discovered, no specific pipeline or tanker routes in the Allantic OCS have been identitied (1) date. These hypothetical trunsportation scenarion are made on the basis of the proximity

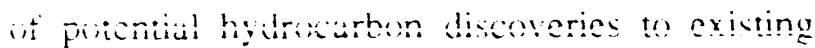

refineries or processing facilities and are developed in consultation with State governments.

Transportation management plans developed under the auspices of the Regional Technical Working Groups (RTWG's) in the Mid- and South Atlantic planning areas have been prepared and are discussed below.

The first version of the Hudson Canyon Transportation Management Plan (HCTMP) was completed and published in June 1981. It was prepared by the Bureau of Land Management's New York OCS Office (which became part of the MMS when it was formed in 1982) with advice and endorsement from the Mid-Atlantic RTWG. The report was initiated because of gas discoveries on adjacent Lease Sale 40 Blocks 598. 599. and 642: these were later determined to be noncommercial. With the possibility of a gas pipeline originating from these blocks, the HCTMP focuses on the off shore enviromment from the area of the blocks to the New Jersey coastline from Sandy Hook to Cape May. The 


\section{Transportation of Hydrocarbon Products Stipulation for Alaska OCS Leases}

The following stipulation stating the Federal Government's preference for pipeline transportation of hydrocarbons from OCS wellhead to shore has been attached to lease: in the Beaufort Sea, Norton Basin, St. George Basii, Cock Inlet, and Gulf of Alaska Planning Areas. It voes not apply to leases in the Navarin Basin. The stipulation reads as follows:

- Pipelines will be required (a) if pipeline rights-of-way can be determined and obtained; (b) if laying such pipelines is technologically teasible and environmentally preferable; and (c) if, in the opinion of the lessor, pipelines can be laid without net social loss, taking into account any incremental costs of pipelines over alternative methods of transportation and any incremental beneits in the form of increased environmental protection of reduced multiple-use conflicts. The lessor specifically reserves the right to require that any pipeline used for transporting production to snore be placed in certain designated management areas. In selecting the means of rransportation, consideration will be given to any recommendation of the Regional Technical Working Group for assessment and management of transportation of OCS oil and gas with participation of Federa!, State, and local governments and the industry.

- All pipelines, including both flow lines and gathering lines for oil and gas, shall be designed and constructed to provide for ad equate protection from water currents, storms, and ice scouring, permafrost. subfreezing conditions, and other nazards as determined on a case-by-case basis.

- Following the development of sufficient pipeline capacity, no crude oil production will be transported by surface vessel from offshore production sites, except in the case of emergency. Ceterminations as to emergency conditions and appropriate responses to these conditions will be made by the Regional Supervisor, Field Operations

Where the three criteria set forth in the first senience of this stipulation are not met and surface vansp-ration must be employed, all vessels used tor carryng hydrocarbons to shore from the leased aea ait conform with all standards established for sucr. vesseis, pursuant to the Ports and Waterways Sate: Act of 1972 as amended (33 U.S.C. 1221. E: Sอ7:49 FF 2973: report identifies constraints that may affect the siting of a pipeline within the study area. Five small areas were identified as having constraints that should be avoided in pipeline siting: a geologic slump area, a mud-dump site, two explosive dump sites, and an anchorage ground off Sandy Hook, New Jersey. The rest of the offshore area may be suitable for a gas pipeline if appropriate enginecring and pipeline design techniques, as identified in the report, are used. The report identifies areas where other offshore activities occur that also must be accommodated. These areas include vessel traffic locations, military-use areas, underwater cable locations, and fishery areas. The HCTMP contains maps depicting these constraint areas, and it presents nine specific recommendations concerning pipeline siting and design. In addition, Federal and State legal requirements are also discussed.

The HCTMP is intended to provide information necessary to make decisions on whether to accept or reject a pipeline proposal. The report also contains information concerning mitigation techniques that should be used when pipeline routes are proposed. Specific pipeline routes, however, are not identified.

The South Atlantic Regional Transportation Management Plan (RTMP) was also published in June 1981. The study area extended from approximately the North Carolina-Virginia boundary south to Cape Canaveral, Florida. The RTMP is principally an integration of regulatory frameworks, policies, and plans that are applicable to pipeline siting from each of the South Atlantic Coast States. The regulatory framework of the Federal agencies involved in the South Atlantic OCS jurisdictional area is also incorporated into the RTMP. The plan identifies three levels of working plans, which are distinguished by their degree of detail in relation to OCS actions. The three levels are as follows:

- Level 1.-Broad, macro-level planning to inventory existing values and anstraints. used in areas having no leased blocks, but with blocks on a tentative bleck list. 
- Level II.-Refinement in detail of Level I plan to identify high-risk or sensitive areas, used in areas having leased blocks, but with no marketable discoveries.

- Level III.-Detailed planning of coastal zone and Federal waters and classification of areas into one of three management classes, used in specific zones shoreward from marketable discoveries.

The RTMP incorporates the first two planning levels, which coincides with the degree of South Atlantic OCS activities to date. The States of North Carolina and South Carolina have completed Level I planning efforts. The States of Georgia and Florida and the Federal agencies involved in OCS transportation planning have completed the Level II planning stage. The RTMP also identifies important coastal and nearshore areas. Many of these areas (e.g., parks and wildlife refuges) are important because they relate to State policies and plans.

In the North Atlantic Planning Area, two States have taken the lead in transportation planning for the OCS. The Massachusetts Coastal Zone Management Program conducted a preliminary pipeline siting study for natural gas originating from the OCS. The study focused on the types of data necessary in the identification of natural gas pipeline corridors, including physical, geological, and biological features and existing land-use patterns. The study resulted in preliminary identification of potential pipeline corridors.

The Rhode Island Office of Statewide Planning conducted an energy facilities siting study that considered petroleum storage facilities, refineries, power plants, and pipeline corridors. The study provided a comprehensive review of legal, environmental, and socioeconomic factors important to the siting process. A case study was presented in which a computer model was applied to a hypothetical pipeline landfall in Little Compton, Rhode Island.
Many other Atlantic Coast States have prepared studies addressing transportation of OCS resources. A number of these were funded with grants from the Federal Coastal Energy Impact Program.

\section{Gulf of Mexico OCS Region}

In addition to the large amounts of crude oil and natural gas produced in the Gulf of Mexico OCS, the Gulf coast receives transshipments of Aluskan and California crude oil, as well as a large part of the crude oil imported into the country. These factors have resulted in a highly developed hydrocarbon transportation system, both pipeline and tanker, in the Gulf region. Including both State and Federal waters, the Gulf of Mexico contains the most extensive offshore pipeline network in the world. Approximately 64 percent of all Gulf of Mexico OCS pipelines are located in the Central Gult of Mexico Planning Area. The remaining 36 pereent are in the Western Gulf of Mexico Planning Area. Currently, there are no pipelines projects in the Eastern Gulf of Mexico. Figure 4-1 (p. 142) shows the number of pipeline projects approved by MMS and the total mileage for the period 1983-89.

Each year, hundreds of miles of pipelines are added to the already extensive pipeline network in the Gulf of Mexico. For the most part, the additions are sections of small-diameter gathering flowlines, linking new platforms to a major pipcline system or adding to the capacity of the system by running a new line parallel to the existing trunkline.

A number of major gas pipeline systems have been constructed in the Western Gulf of Mexico OCS, including the Central Texas Gathering System (CTGS) and the High Island Offshore Sys$1 \mathrm{~cm}$ (HIOS). The CTGS carries dedicated gas reserves from Brazos, Galveston, Matagorda Island, and Mestang Island offishore areas to a processing plant at Markham, Texas, west of Freeport. The HIOS is composed of 203 miles of main trunk pipeline servicing the High Is- 


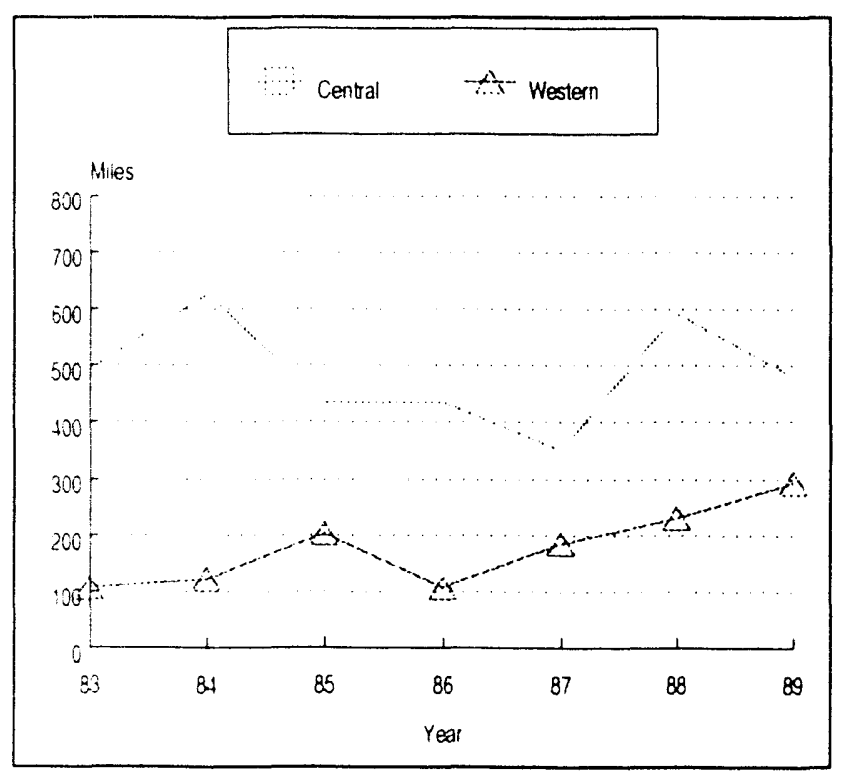

Figure 4-1. Pipeline projects approved by MMS and total mileage, 1983-89.

land and adjoining leased areas. Producers build lateral pipelines that connect with this system to transport their gas. The HIOS gas is transported ashore near the Texas-Louisiana border for final processing.

Vessel transportation is used infrequently to carry ashore crude oil and condensate produced on the Gulf OCS. However, tankers de carry a significant amount of crude oil to Gulf ports from Alaska, California, and overseas. With its abundant refineries and onshore pipeline networks, the Gulf of Mexico OCS Region has become a major center for handling imported oil.

The anticipated increase in demand for imported crude oil in the mid-1970's, following the Arab oil cmbargo, produced numerous proposals to develop centralized, high-volume facilitics in the Gulf of Mexico OCS Region. These proposals included the dredging of existing channels and ports and the construction of deep-water ports or transshipment terminals to accommodate the supertankers being built to transport the anticipated quantities of oil.
Although there have been additional proposals, to date only one offshore oil port has been built in U.S. waters. The Louisiana Offshore Oil Port (LOOP), first planned in 1972, is located about 18 miles off the Louisiana coast, south of New Orleans, in 110 feet of water. The facility consists of a pump platform, a control platform, and three single-anchor leg mooring buoys. Crude oil is pumped from the tanker's cargo hold to LOOP's pumping platform in flexible, floating hoses and then to shore in a 48 -inch submarine pipeline. The pipeline continues 28 miles inland to the Clovelly Salt Dome Storage Terminal for temporary storage. The LOOP design capacity is $1.4 \mathrm{MMbpd}$, but practical operating capacity is closer to $1.2 \mathrm{MMbpd}$ because of limitations of ships pumping capacities. When originally designed in the late $1970^{\circ} \mathrm{s}$, it was anticipated that much bigger tankers would be calling at the facility. Since beginning operations in May 1981, the facility has been operating far below this capacity. The facility was built by a consortium of oil companies - Marathon, Texaco, Shell, Ashland, and Murphy. Although the facility has becn recognized by the Coast Guard and others as a success environmentally, spilling almost no oil, it has been a disaster financially. It cost between $\$ 700$ and $\$ 800$ million to build, and loses money many months of the year.

As a result of the Exxon Valdez tanker oil spill in March 1989, and a rash of other tanker spills since then, oil industry and government officials have been debating how oil-spill risks to coastal areas can be reduced. The Bush Administration, through Secretary of the Interior Manuel Lujan, has supported the idea of additional offshore oil ports. In July 1989, Secretary Lujan suggested a plan that would bar oil tankers from U.S. ports, requiring them to unload several miles offshore. He also created an Interior Department task force to evaluate the economic and environmental feasibility of offshore oil ports. Secretary Lujan visited the LOOP in September 1989. In response to the Secretary's directive, MMS issued the report Offshore Oil Terminals (MMS Report 9()-()()|4) 
in July 199(). This report made the following conclusions:

- Tanker transport of imported crude oil will increase, and domestic use of tankers will continue.

- Of the U.S.s petroleum volume, 88 percent is handled by 11 ports; the majority of the Nation's petroleum volume could be handled with the construction of six offshore oil ports.

- Offshore oil ports may provide a means of reducing tanker accidents, tanker-related oil spills, and the environmental damage they would cause.

- Replacement of all nearshore tanker and barge traffic with of fshore oil ports and pipeline networks would be expensive, and sources of funding uncertain.

- Significant questions remain regarding the environmental and economic effects of building offshore oil terminals and pipcline sysiems.

- Risks associated in transporting oil could be reduced with other means such as stricter regulation, increased liability, or oil transport fees based on risk.

In July 1990, the Texas Water Commission indicated that offshore oil ports should be considered. The Commission called for an economic feasibility study for a "LOOP-like" port offshore Texas.

In September 1990, a proposal to build a second offshore oil port (TexPort) was announced. TexPort would be 27 miles off Freeport, Texas, in $110 \mathrm{fect}$ of water. Two submarine pipelines would carry the oil ashore to a tank farm 5 miles inlund. The proposal was sponsored by a consortium of 18 companies, headed by Phillips Petrolcum and including Exxon, Mobil, ARCO, and Shell. Amoco has also expressed interest in the project. Texport is estimated to cost between $\$ 60()$ million and $\$ 1.3$ billion, depending on capacity. If constructed at the larger capacity, it would have a throughput of 2 MMbpd. The consortium is going ahcad with Phase Two of the project, which includes a marketing survey and review of the regulatory and permitting requirements.

\section{Pacific OCS Region}

The majority of Pacific OCS reserves to date are located off of Santa Barbara County; development fields in the Santa Barbara Channel and Santa Maria Basin are located primarily off the County`s shores.

The State of California has addressed hydrocarbon transportation through the California Coastal Oil Pipeline Planning Act of 1980, which identifies pipelines as the preferred mode of transport. Santa Barbara County has also adopted this policy. The Oil Transportation Plan and Environmental Impact Report (collectively referred to as the OTP, prepared by the Energy Division of the Resource Management Department of Santa Barbara County in 1984) was prepared to address the cumulative impact of the offshore oil and gas development and advocated the use, where possible, of consolidated onshore facilities. Although the Federal Government regulates oil and gas development on the OCS, efficient, large-scale industry activity requires nearby shore-based support and transportation facilitics. 'ihus, development of OCS resources in much of the Pacific OCS Region required de facto approval by Santa Barbara County.

Pipeline construction on the Pacific OCS, though sporadic, can be associated with various development projects. Figure 4-2 (p. 144) presents information on the offshore pipeline construction in Federal OCS waters in the Pacific OCS Region from 1967 to the end of 1989. The peak in 1968 (an be linked to development of the Dos Cuadras field. The increase in construction in 1979 and 1981 can be attributed to development of the Santa Clara Unit and 


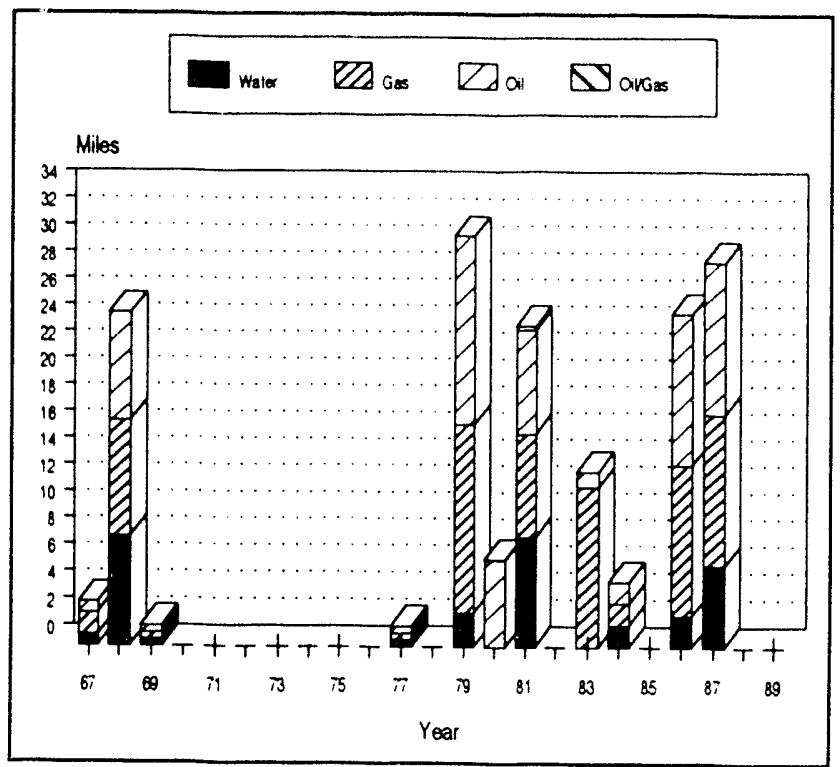

Figure 4-2. Offshore pipeline construction from sites originating in the Pacific OCS Region, 1967-89.

some Beta Unit development. Construction in 1983 was a result of pipeline placed from Platform Habitat and the Pitas Point Unit to shore. Some tie-ins between Platform Edith and Platforms Elly and Ellen (Beta Unit) and between Hondo and shore accounted for additional 1983 construction. Table 4-2 (p. 145 ) displays data on existing and proposed offshore pipelines in Federal waters. The pending development and production projects will add a significant number of miles to the offshore pipeline network, but this increase will likely occur over several years.

In an effort to accommodate additional offshore and onshore production, Phase One of the interstate Celeron-All American Pipeline project was completed in early 1987 . This pipeline will potentially transport crude oil from the Santa Barbara Channel area and the central and northern Santa Maria Basin area to refineries on the Gulf Coast in Texas. Construction began in August 1990 on the All American Pipeline Company's 24-inch diameter coastal segment from the Gaviota pump station to the proposed All American pump station at Las Flores Canyon, and will continue through November 1990.
The booster pump stations are being completed (as of October 31, 1990).

Another interstate crude-oil pipeline was in the permitting stage. Known as the Pacific Texas (Pactex) Pipeline project, this pipeline approximately parallels the same route as that of the $C$..ron-All American Pipeline and is proposed as an alternative route from marine terminals in the Los Angeles area for Alaskan North Slope crude. The Pactex Pipeline would have been 1,030 miles long with a capacity of 900 Mbpd. On January 14, 1989, the Bureau of Land Management executed an adverse cancelation of the pipeline company's right-of-way grant for failure to pay required rent.

A major intrastate project, known as the Southern California Pipeline System, was proposed to transport crude oil from the Santa Barbara Channel area and the San Joaquin Valley (onshore), where crude oil from onshore fields in this area will be added and then transported to refineries in the Los Angeles area. The Southern California Pipeline System capacity would have been $330 \mathrm{Mbpd}$. The project would have had two sections: (1) the Las Padres Pipeline from Gaviota to Emidio and (2) the Angeles Pipeline from Emidio to five Los Angeles area refineries. The project has been on hold since March 1988 when the California Department of Transportation withdrew its notice of determination for the EIR. Numerous municipalities had indicated they would file litigation to block the project.

\section{Onshore Support Facilities}

The search for and development of offshore hydrocarbons requires onshore support facilities that either process or transship materials or personnel to offshore locations where they are needed. Following an offshore discovery and its subsequent development, initial separation/treatment facilities located onshore are required to prepare the hydrocarbons produced offshore for shipment to refineries or processing plants or for sale to distributors. 
Table 4-2. Existing and proposed OCS pipelines offshore California as of October 31, 1989

\begin{tabular}{|c|c|c|c|c|c|}
\hline $\begin{array}{l}\text { UNIT/ } \\
\text { (Field) }\end{array}$ & Platform & $\begin{array}{l}\text { Pipeline } \\
\text { operator }\end{array}$ & Landfall & $\begin{array}{l}\text { Size and } \\
\text { type }\end{array}$ & Status \\
\hline SANTA YNEZ & Hondo(1) to shore & POPCO & \multirow{2}{*}{$\begin{array}{l}\text { Las Flores } \\
\text { Canyon }\end{array}$} & $12-$ in gas & Operating \\
\hline (Hondo) & Hondo to OS\&T & Exxon & & $\begin{array}{l}12-\text { in oil } \\
6 \text {-in fuel } \\
8 \text {-in water }\end{array}$ & Operating \\
\hline (Dos Cuadras) & $C$ to $B$ & Unocal & $(2)$ & $\begin{array}{l}6 \text {-in oil } \\
6-\text { in gas } \\
6 \text {-in water }\end{array}$ & Operating \\
\hline (Dos Cuadras) & $B$ to $A$ to Shore & Unocal & Rincon & $\begin{array}{l}12 \text {-in oil } \\
12 \text {-in gas } \\
6 \text {-in water }\end{array}$ & Operating \\
\hline (Dos Cuadras) & Hillhouse to A & Oryx & (2) & $\begin{array}{l}8-\text { in oil } \\
8-\text { in gas } \\
6 \text {-in water }\end{array}$ & Operating \\
\hline $\begin{array}{l}\text { (Dos Cuadras/ } \\
\text { Carpinteria Offshore) }\end{array}$ & $\begin{array}{l}\text { Henry to Hillhouse } \\
\text { Hillihouse to Henry }\end{array}$ & Oryx & (2) & $\begin{array}{l}\text { 8-in oil } \\
6-\text { in fuel gas } \\
\text { 8-in processed }\end{array}$ & $\begin{array}{l}\text { Operating } \\
\text { water/gas }\end{array}$ \\
\hline (Carpinteria Offshore) & $\begin{array}{l}\text { Hogan to Houchin } \\
\text { to shore }\end{array}$ & Phillips & La Conchita & $\begin{array}{l}10-\text { in oil } \\
12-\text { in gas } \\
10-\text { in gas lift } \\
4 \text {-in water }\end{array}$ & Operating \\
\hline $\begin{array}{l}\text { PITAS POINT/ } \\
\text { (Pitas Point) }\end{array}$ & Habitat to shore & $\begin{array}{l}\text { Pacific Interstate } \\
\text { Offshore Company }\end{array}$ & Carpinteria & $12-$ in gas & Operating \\
\hline $\begin{array}{l}\text { SANTA CLARA/ } \\
\text { (Sockeye) }\end{array}$ & Gail to Grace & Chevron & $(2)$ & $\begin{array}{l}8 \text {-in oil } \\
8 \text {-in gas } \\
8 \text {-in service }\end{array}$ & Operating \\
\hline $\begin{array}{l}\text { SANTA CLARA/ } \\
\text { (Santa Clara) }\end{array}$ & $\begin{array}{l}\text { Grace to Hope (State } \\
\text { waters) } \\
\text { Hope to shore }\end{array}$ & Chevron & Carpinteria & $\begin{array}{l}12-\text { in oil( }(3) \\
10-\text { in gas }(3) \\
10-\text { in oil } \\
10-\text { in gas } \\
10-\text { in gas lift }\end{array}$ & Operating \\
\hline $\begin{array}{l}\text { SANTA CLARA/ } \\
\text { (Santa Clara) }\end{array}$ & Gilda to shore & Unocal & Mandalay Beach & $\begin{array}{l}12-\text { in oil/water } \\
10-\text { in gas } \\
6-\text { in water retu }\end{array}$ & Operating \\
\hline POINT HUENEME & Gina to shore & Unocal & Mandalay Beach & $\begin{array}{c}\text { 10-in oil/ } \\
\text { gas (4) } \\
6 \text {-in water }\end{array}$ & Operating \\
\hline BETA/(Beta) & Ellen to Elly & SWEPI & (2) & $\begin{array}{l}14-\text { in oil } \\
4-\text { in gas }\end{array}$ & Operating \\
\hline BETA/(Beta) & Elly to shore & SWEPI & Long Beach & 16-in oil & Operating \\
\hline BETA/(Beta) & Eureka to Elly & SWEPI & $(2)$ & $\begin{array}{l}12-\text { in oil } \\
6-\text { in gas } \\
10-\text { in water }\end{array}$ & Operating \\
\hline BETA/(Beta) & Edith to Elly & Unocal & $(2)$ & 6-in oil & Operating \\
\hline BETA/(Beta) & $\begin{array}{l}\text { Edith to Eva (State } \\
\text { waters) to shore }\end{array}$ & Unocal & Huntington Beach & 6 -in gas & Operating \\
\hline (Point Arguello) & Hermosa to shore & Chevron & Point Conception & $\begin{array}{l}24-\text { in oil } \\
20-\text { in gas }\end{array}$ & Installed \\
\hline (Point Arguello) & Harvest to Hermosa & Texaco & (2) & $\begin{array}{l}12-\text { in oil } \\
8 \text {-in gas }\end{array}$ & Installed \\
\hline (Point Arguello) & Hidalgo to Hermosa & Chevron & (2) & $\begin{array}{l}16-\text { in oil } \\
10-\text { in gas }\end{array}$ & Installed \\
\hline POINT PEDERNALES & Irene to shore & Unocal & $\begin{array}{l}\text { Vandenberg Air } \\
\text { Force Base }\end{array}$ & $\begin{array}{l}20 \text {-in oil } \\
8-\text { in gas } \\
8-\text { in water }\end{array}$ & Operating \\
\hline POINT PEDERNALES & Iris to Irene & Unocal & (2) & $\begin{array}{l}10-\text { in oil } \\
6 \text {-in gas }\end{array}$ & Proposed \\
\hline (San Miguel) & Julius to shore & SWEPI & Guadalupe Field & $\begin{array}{l}20-\text { in oil } \\
10-\text { in water } \\
8 \text {-in service/ } \\
\text { fuel }\end{array}$ & Proposed \\
\hline
\end{tabular}

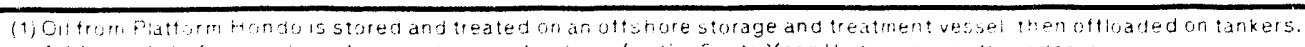

Addionai piaffom and wheline emolacement detuons for the Santa Ynez Unit are currently uncer revew.

(2) Iridicates proelirielinks i wo platforms.

(3) Lines trom Platform Grace to Flattorm Hope.

(4) One line carres ont and gas. 
The expression "onshore support facilities" as used in this report means shore-based facilities directly supporting the exploration, development, production, transportation, or treatment, separation, and refinement of hydrocarbons derived from offshore fields. These facilities include (1) major supply bases, (2) crew and light supply bases, (3) fabrication and assembly facilities, (4) onshore separation/treatment facilities, and (5) refineries and gas processing plants. More information on each of these categories of onshore facilities follows.

\section{Alaska OCS Region}

Alaska oil and gas activities began to increase rapidly in the mid-1960's with the discovery of oil, both onshore and offshore, on State leases at Prudhoe Bay and offshore on State licases in the Cook Inlet. Since that time, an extensive network has developed to serve the needs of both Prudhoe Bay and the Cook Inlet fields. This onshore infrastructure, with some exceptions, has been a primary source of support for Alaska OCS exploratory activities since the first OCS well was drilled on a Federal OCS lease in the Gulf of Alaska in 1976. (See ch. 3, p. 88, for more information on Alaska OCS Region drilling).

These exploratory activities required onshore support to a varying degree, but usually on a relatively short-term basis. From 1976 through 1985, industry explored a number of remote areas within the Alaska OCS Region, with numerous locations along the coast of Alaska used to support these activities. These locations were identified and briefly described in table 4-3 (p. 147).

Because of the remote nature of many of these exploratory projects, these projects were virtually self-contained (except for personnel). Many drilling vessels carricd (either onboard the vessel itself, or on barges stationed close to the well sites) months worth of drilling supplies and equipment. Multiple exploratory wells could then be drilled from these vessels without having to return to the onshore sites for major re- supplying, thus reducing the number of trips to and from onshore support areas.

From 1986 through 1988, the only OCS exploratory programs conducted in Alaska occurred in the Beaufort Sea. Beaufort Sea exploration is generally supported from the Prudhoe BayDeadhorse industrial complex, which has supported onshore development and production programs since oil was discovered at Prudhoe Bay in 1967. The airfield and warehousing facilities used to support these offshore operations previously existed as part of the Prudhoe Bay onshore oil production operation.

An exception to this general pattern was made by Amoco during the 1986 drilling of its Mars Prospect, which was drilled from a 950 foot-diameter manmade spray-ice island located 5 miles offshore Cape Halkett. Although the drilling rig was towed to the drill site from Deadhorse, the main work camp and airstrip were located onshore at Cape Halkett. The work camp pad, airstrip, and 5-mile service road connecting the camp and drill site were constructed of ice created by water flood.

In 1989 and 1990, exploratory activity shifted to the Chukchi Sea Planning Area (see discussion in ch. 3, p. 94), with Shell Oil company drilling a number of wells offshore Icy Cape. This project has been supported from two onshore locations. Air support was provided by the Naval Arctic Research Lab Facility at Point Barrow, and marine support was provided by the Crowley Terminal in Kotzebue.

\section{Atlantic OCS Region}

Offshore operations on the Atlantic OCS have also been exploratory in nature and have been supported by temporary service bases established and operated by (or contracted for) the offshore operators. Such temporary service bases are generally located at the most convenient shore-based location that will allow the operator to service and supply off shore drilling rigs efficiently, cheaply, and with a minimum of travel. 
Table 4-3. Actual or potential Alaska OCS Region support facilities

\begin{tabular}{|c|c|c|c|}
\hline $\begin{array}{l}\text { Name } \\
\text { of } \\
\text { facllity }\end{array}$ & $\begin{array}{l}\text { Type of } \\
\text { service/ } \\
\text { support }\end{array}$ & $\begin{array}{l}\text { Planning } \\
\text { area } \\
\text { servlced }\end{array}$ & $\begin{array}{l}\text { Description } \\
\text { of } \\
\text { facllity }\end{array}$ \\
\hline $\begin{array}{l}\text { Deadhorse Airport } \\
\text { ARCO Airport }\end{array}$ & Airport & Arctic Subregion & 6,500- $\mathrm{ft}$ paved airstrip, 5,500- $\mathrm{tt}$ gravel airstrip \\
\hline $\begin{array}{l}\text { West Dock } \\
\text { East Dock } \\
\text { Prudhoe Bay }\end{array}$ & Port & Arctic Subregion & $\begin{array}{l}\text { Limited harbor facilities available late July to early } \\
\text { September for use during approximately } 6 \text {-week ice-free } \\
\text { season for sealifts. West Dock--1.5-mile gravel } \\
\text { causeway; East Dock--shallow-water dock onshore }\end{array}$ \\
\hline $\begin{array}{l}\text { Oliktok Point } \\
\text { Kuparuk }\end{array}$ & Port & Arctic Subregion & Limited harbor facilities \\
\hline Dutch Harbor & Port & $\begin{array}{l}\text { Bering Sea } \\
\text { Subregion }\end{array}$ & Ice-free, deep-water, natural anchorage \\
\hline $\begin{array}{l}\text { Unalaska City } \\
\text { Airport }\end{array}$ & Airport & $\begin{array}{l}\text { Bering Sea } \\
\text { Subregion }\end{array}$ & $4,000-\mathrm{ft}$ airport runway being extended by $2,000 \mathrm{ft}$ \\
\hline Cold Bay Airport & Airport & $\begin{array}{l}\text { Bering Sea } \\
\text { Subregion }\end{array}$ & 2 paved runways $--5,162 \mathrm{ft}$ and $10,415 \mathrm{ft}$ \\
\hline Nome Harbor & Port & $\begin{array}{l}\text { Bering Sea } \\
\text { Subregion }\end{array}$ & $\begin{array}{l}\text { Plans for a } 3,500-\mathrm{ft} \text { gravel causeway dock with } 27-\mathrm{ft} \\
\text { draft capabilities; existing lighterage operations only. } \\
\text { Existing causeway is } 2,600 \text { it }\end{array}$ \\
\hline Nome Airport & Airport & $\begin{array}{l}\text { Bering Sea } \\
\text { Subregion }\end{array}$ & 2 paved airstrips $--6,039-\mathrm{ft}$ and $5,610-\mathrm{ft}$ \\
\hline Nome City Airport & Airport & $\begin{array}{l}\text { Bering Sea } \\
\text { Subregion }\end{array}$ & $3,200-\mathrm{tt}$ gravel airstrip \\
\hline $\begin{array}{l}\text { St. Paul Island } \\
\text { Airport }\end{array}$ & Airport & $\begin{array}{l}\text { Bering Sea } \\
\text { Subregion }\end{array}$ & $5,175-\mathrm{ft}$ gravel airstrip \\
\hline Unalakleet & Airport & $\begin{array}{l}\text { Bering Sea } \\
\text { Subregion }\end{array}$ & $6,567-\mathrm{ft}$ gravel airstrip \\
\hline Moses Point & Airport & $\begin{array}{l}\text { Bering Sea } \\
\text { Subregion }\end{array}$ & $4,653-\mathrm{ft}$ gravel airstrip \\
\hline $\begin{array}{l}\text { Gambell on } \\
\text { St. Lawrence Island }\end{array}$ & Airport & $\begin{array}{l}\text { Bering Sea } \\
\text { Subregion }\end{array}$ & $4,251-\mathrm{ft}$ gravel airstrip \\
\hline Yakutat Airport & Airport & $\begin{array}{l}\text { Gulf of Alaska } \\
\text { Subregion }\end{array}$ & $\begin{array}{l}3,600 \text { acres, with } 2 \text { helicopter hangar facilities } \\
2 \text { paved runways }--7,748 \mathrm{ft} \text { and } 7,813 \mathrm{tt}\end{array}$ \\
\hline $\begin{array}{l}\text { Yakutat/Monti } \\
\text { Bay Harbor }\end{array}$ & Port & $\begin{array}{l}\text { Gulf of Alaska } \\
\text { Subregion }\end{array}$ & 115-ft pier for workboats, deep water \\
\hline Kenai Harbor & Port & $\begin{array}{l}\text { Gulf of Alaska } \\
\text { Subregion }\end{array}$ & $\begin{array}{l}\text { Rig tenders deep-water dock at Nikiski ( } 10 \text { miles north } \\
\text { of Kenai) }\end{array}$ \\
\hline Homer Harbor & Port & $\begin{array}{l}\text { Gulf of Alaska } \\
\text { Subregion }\end{array}$ & City-owned deep-water dock on Homer spit \\
\hline Homer Airport & Airport & $\begin{array}{l}\text { Gult of Alaska } \\
\text { Subregion }\end{array}$ & $7,400-f t$ paved airstrip \\
\hline Kodiak Harbor & Port & $\begin{array}{l}\text { Gulf of Alaska } \\
\text { Subregion }\end{array}$ & $\begin{array}{l}\text { Channel: minimum } 22-\mathrm{ft} M L L W^{*} \text { depth, } 200-\mathrm{ft} \text { width; } \\
\text { breakwaters: } 1,250 \text { and } 760 \mathrm{ft} \text { long }\end{array}$ \\
\hline $\begin{array}{l}\text { Port Lions/ } \\
\text { Kodiak Airpont }\end{array}$ & Airport & $\begin{array}{l}\text { Gulf of Alaska } \\
\text { Subregion }\end{array}$ & 3 paved runways $--7,548 \mathrm{ft}, 5,398 \mathrm{ft}$ and $5,011 \mathrm{ft}$ \\
\hline Seward Airport & Airport & $\begin{array}{l}\text { Gult of Alaska } \\
\text { Subregion }\end{array}$ & $4,600-f t$ paved airstrip \\
\hline Seward Harbor & Port & $\begin{array}{l}\text { Gulf of Alaska } \\
\text { Subregion }\end{array}$ & $\begin{array}{l}\text { Channel: minimum } 15-\mathrm{ft} \text { MLLW* depth, } 120-\mathrm{ft} \text { width; } \\
\text { breakwaters: } 2 \text { rock mounds } 1,060 \text { and } 1,750 \mathrm{ft} \text { long, } \\
\text { with provision for further basin expansion }\end{array}$ \\
\hline
\end{tabular}


Since August 1976, three sites have been used or considered as temporary service and support bases. These include the port at Quonset Point-Davisville, Rhode Island, the harbor and port facilities at Morehead City, North Carolina, and the port at Brunswick, Georgia.

Presently, no permanent onshore facilities are dedicated to the support of OCS activities adjacent to the Atlantic OCS Region. With no commercial discoveries of hydrocarbons in the Atlantic OCS, such facilities are not needed.

\section{Gulf of Mexico OCS Region}

Onshore hydrocarbon production in the Gulf of Mexico started many years before off shore exploration began. As a result, the well-developed regional infrastructure that had evolved for onshore oil and gas production was casily expanded to accommodate offshore production. However, some specific support activities, such as platform fabrication, pipelaying, diving and transportation services, and boat building, owe their existence entirely to the offshore oil and gas industry.

Because of its long history of off shore oil and gas production, the Gulf has the most welldeveloped onshore support base in the country. This support activity provides an important contribution to the local economy of many coastal communities in the Gulf.

The majority of these offshore facilities are located in Texas and Louisiana, where offshore exploration has been concentrated. Platform fabrication, boat building, transportation, supply, and diving services are located throughout the coastal regions of these two States and have become an important part of the local economy. Although some service companies form a permanent core group, many others form a loose assemblage that appears and disappears as the geographic focus of offshore activity shifts and the demand for services changes.

The lecations of onshore support facilities for ciult oc's exploration and development have been determined by their access to Gulf waters, as well as their proximity to areas of offshore activity. As a result, the areas of New Orleans, Houma, Morgan City, and New Iberia in Louisiana and of Beaumont, Holiston, Frecport, and Corpus Christi in Texas have become centers for offshore platform and pipeline fabrication and work, supply, and crew boat operations. Helicopter support services have sprung up all along the Texas and Louisiana coast. Crude oil refineries, which support both onshore and offshore production and do not require proximity to the Gulf, have developed throughout the Gulf Coast. However, refining capacity has generally been concentrated in the metropolitan areas of Lake Charles, Baton Rouge, and New Orleans, Louisiana, and Beaumont, Houston, Galveston, and Corpus Christi, Texas.

The fate of the support industries closely follows that of OCS exploration and development. Thus, support industries experienced steady growth through the mid-and late 1970's. Between 1980) and 1983, these industries prospered and expanded as the oil and gas industry expanded its Gulf capacity rapidly. During the late 1980's, the decrease in demand for oil and gas and the resultant drop in world prices had slowed drilling activity in the Gulf and had caused considerable hardship among the support industries. During this period, many of the support industries had to implement survival policies regarding their business activities. Initially, company staffs were reduced, and company stockpiles of goods were allowed to reach low levels. Now, as the service and supply industry prepares for increased exploratory drilling and deep-water development activity, the companies may be reluctant to produce large stockpiles of goods without sufficient compensation and assurances that this higher level of activity will continue through 1991.

In addition to potential equipment and supply shortages, specialized personnel shortages are also begirining io show. The technology has changed somewhat since the early 1980)s, and it is going of take time to train people to use 
the new technology. For example, computers are now heing used much more widely by mud engineers than they were in 1982 and advances in drilling technology call for : more specialized operator.

In the past few yeais. the industry has tended (1) stabilize. Although the level of activity is still lower than it was during the boom years, the overall level has increased. As a result, the net loss of individuals and companies during the late 1980ls, coupled with a rise in activity. has resulted in the industry operating at nearterm capacity. A sudden increase in activity will be hard for the industry to absorb.

Recent activity in the Alabama State waters of Mobile Bay and the Federal OCS Destin Dome area off northwestern Florida may require the development of an onshore support infrastructure in northwestern Florida. Currently, onshore facilities have been developed in Mobile Harbor to support exploration and development in Mobile Bay. The bulk of drilling activity has occurred in Alabama State waters, but drilling in the adjacent Federal waters may increase substantially. Exploration in the Destin Dome area is being supported out of the Port of Panama City.

Approximately to perent of the U.S. oil retining capacity is located within the coastal zones of Texas, Louisiana, Mississippi, and Alabama. This area is recognized as a world leader in hydrocarbon processing.

Spurred by strong product demand, stable feedurecks, and product prices, refining capacity rose for the fith straight year in 1990). As shown in tigure $4-3$ (top right), refining capacity has risen each year since 1985. While the rise in refining capacity has not approached the record level of 18.6 $11 . \mathrm{Mbped}$ set in 1981. the steady rise has allowed the industry to continue 16) regroup, rekesign, and upgrade facilities in terms of automation and efficiency. Figure 4-4 (right) shous the design capacity and hroughput (in barrels of oil per day) of coastal refineries in the (jult of Mexico Region and the number of refineries hut down as of January 1, 1990.

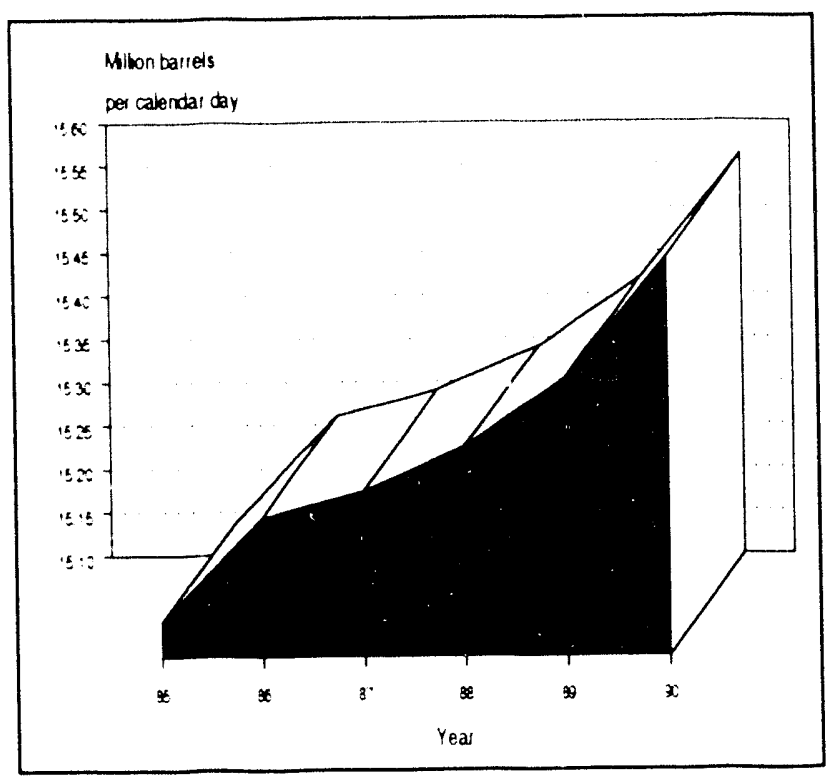

Figure 4-3. U.S. refining capacity, 1985-90.

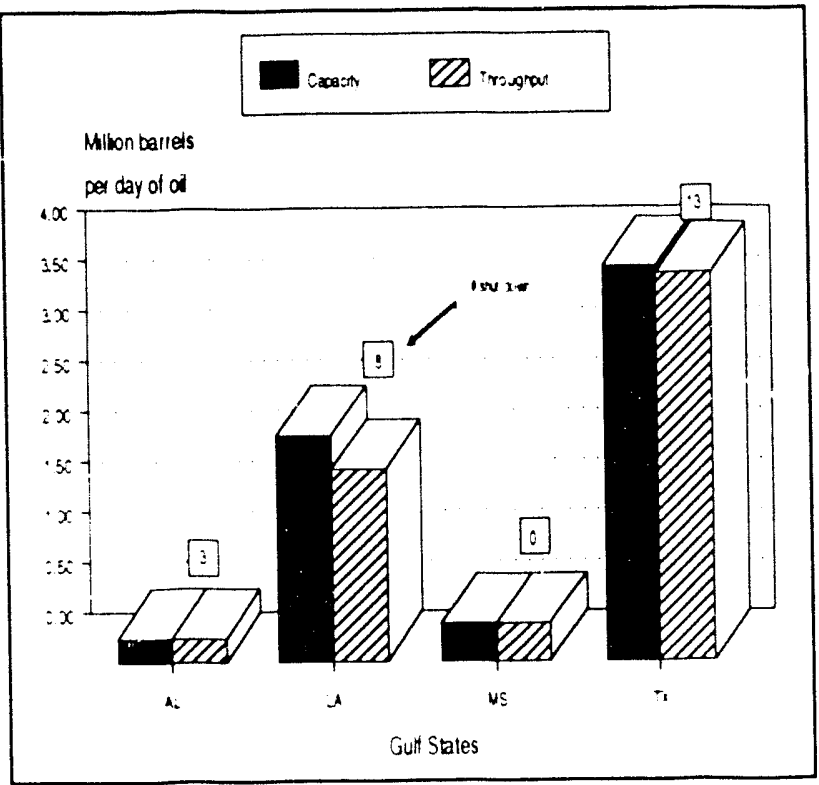

Figure 4-4. Design capacity, throughput, and number of shutdown coastal oil refineries in the Gulf of Mexico OCS Region, by State, as of January 1, 1990.

In this case, shutdown refineries are still available for future production. As the figure shows, there were 24 refineries shut down in the Gulf of Mexico Region on January 1, 1990. 
The utilized refining capacity, for purposes of this report, is defined as the amount that a refinery processed on January 1, 1990). Texas and Louisiana represent about 91 percent of the Gulf Coast refinery design capacity. This percentage has remained relatively constant for several years. The Gulf of Mexico Region boasts the largest gas processing capacity in the Nation. As shown in figure 4-5 (below), Texas and Louisiana provide over 94 pereent of the Gulf Region's gas processing capacity. In terms of throughput, the five Gulf of Mexico States are equally impressive, providing over 53 of the total U.S. gas throughput.

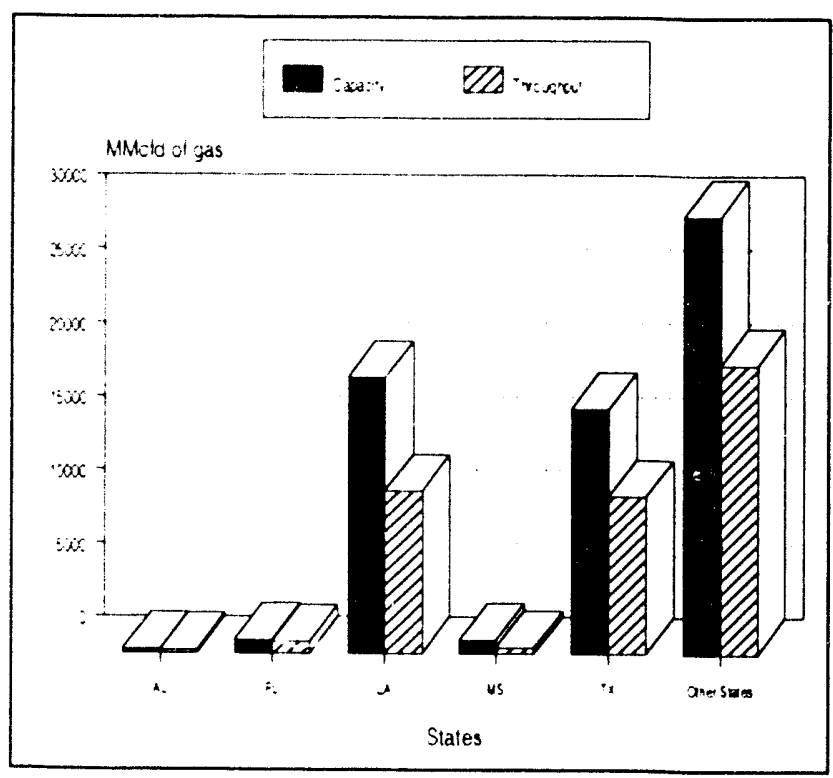

Figure 4-5. Gulf of Mexico regional area gas processing capacity and throughput compared with all other States, as of January 1, 1990.

\section{Pacific OCS Region}

In the Pacific OCS Region, all current offshore exploration and development work is being conducted in the Santa Maria Basin, the Santa Barbara Channel, and the San Pedro Basin, adjacent to Los Angeles. All inajor supplies des. tined for the Santa Maria Basin and the Santa Barbara Channel are transshipped through Port Hueneme, which is lecated in Ventura County. Supply operations for activities in the San Pedro Basin are based out of the Port of les Angeles or the $\mathrm{i}$ rot of Long Beach. The crew and light-supply bases that have been or are currently being used to support activities off shore California include Santa Maria Airport, Lompoc Airport, Ellwood Pier, Santa Barbara Airport, Carpinteria Picr, Ventura Harbor, Port Hueneme, Port of Los Angeles, and Port of Long Beach. Gaviota Pier and Goleta Pier have also been temporarily used as crew and lightsupply bases. The location of these sites are depicted on the map plate (MMS 9()-()I()()). Copies of this plate are available from the following office:

Document Distribution Center

Technical Communication Services

Mincrals Mandgement Service

381 Elden St., MS 453()

Herndon, VA 22()70)-4817

Telephone: (703) 787-108()

Offshore platforms are made up of a number of different components. These components include crew quarters, construction and production modules, the drilling rig - these components are sometimes referred to as topside components - decks, and jackets. During the development phase of offshore operations, operators may contract out all or parts of the construction of the offshore platform to more than one facility.

Several fabrication and assembly facilities located in Califomia and Washington have been $\mathrm{cm}$ ployed for producing the decks and jackets, but none of the existing yards currently have any related coniracts on order. The jackets for Platforms Eurcka, Henry. Hillhouse, Hondo, and Unocal's Plations A, B, and (' were built in 
Pacific Coast fabrication yards. Sec ch. 3, table 3-9 (p. 119) for the name and location of each of these sites.

In recent years, many of the construction contracts for platforms planned for off shore Califormia have been awarded to Japanese, Korean, or Malaysian contractors because of their cost competitiveness. Currently, less than half of the jackets installed on the Pacific OCS have been produced by yards in the United States, although over 70 percent of the decks and topsides have been produced domestically.

Recently, more of the topside construction work for platforms offshore Califormia has been awarded to Pacific Coast yards. Most recently, platform modules for Platform Gail were fabricated by Kaiser Steel at a yard in Stockton, California. Previous deck and module construction was performed by Pacific Coast yards in Port Hueneme, Oakland, Napa, San Bernardino, and Vallejo, California, and in Anacortes and Vancouver, Washington.

Because of the intimate relationship of onshore separation and treatment facilities with specific offshore development and production projects within the Pacific Region, this report addressed these issues together. (See ch. 3, p. 118, for a more detailed discussion of Pacific OCS onshore facilities and the related offshore development and production projects.)

After processing at a separation and treatment facility, crude oil and natural gas produced offshore are transported to a refinery by either pipeline or by barge, where pipelines are not available. Most, though not all, operators of producing acreage offshore California have refineries located in the State. Where possible, crude-oil production is directed to those operator-owned refineries that have excess capacity and that are capable of processing crude having specific characteristics. Those operators that either do not have refineries within the State or that do not have excess capacity will usually either sell their production to local refineries or will transport it to other refinery locations on the Pacific or Gulf of Mexico coasts. Table 4-4 (p. 152) presents a listing of existing Pacific Coast refineries and their operating capacities for the years 1987-90. Those refineries that process crude oil produced offshore California are indicated.

\section{Additional Reading}

Minerals Management Service. July 1990. Offshore Oil Terminals - Potential Role in U.S. Petroleum Distribution. OCS Report MMS 90-0014. 72 p. 
Table 4-4. Pacific Coast active refineries and their operable atmospheric crude oil distillation capacity on January 1, 1987, 1988, and 1989

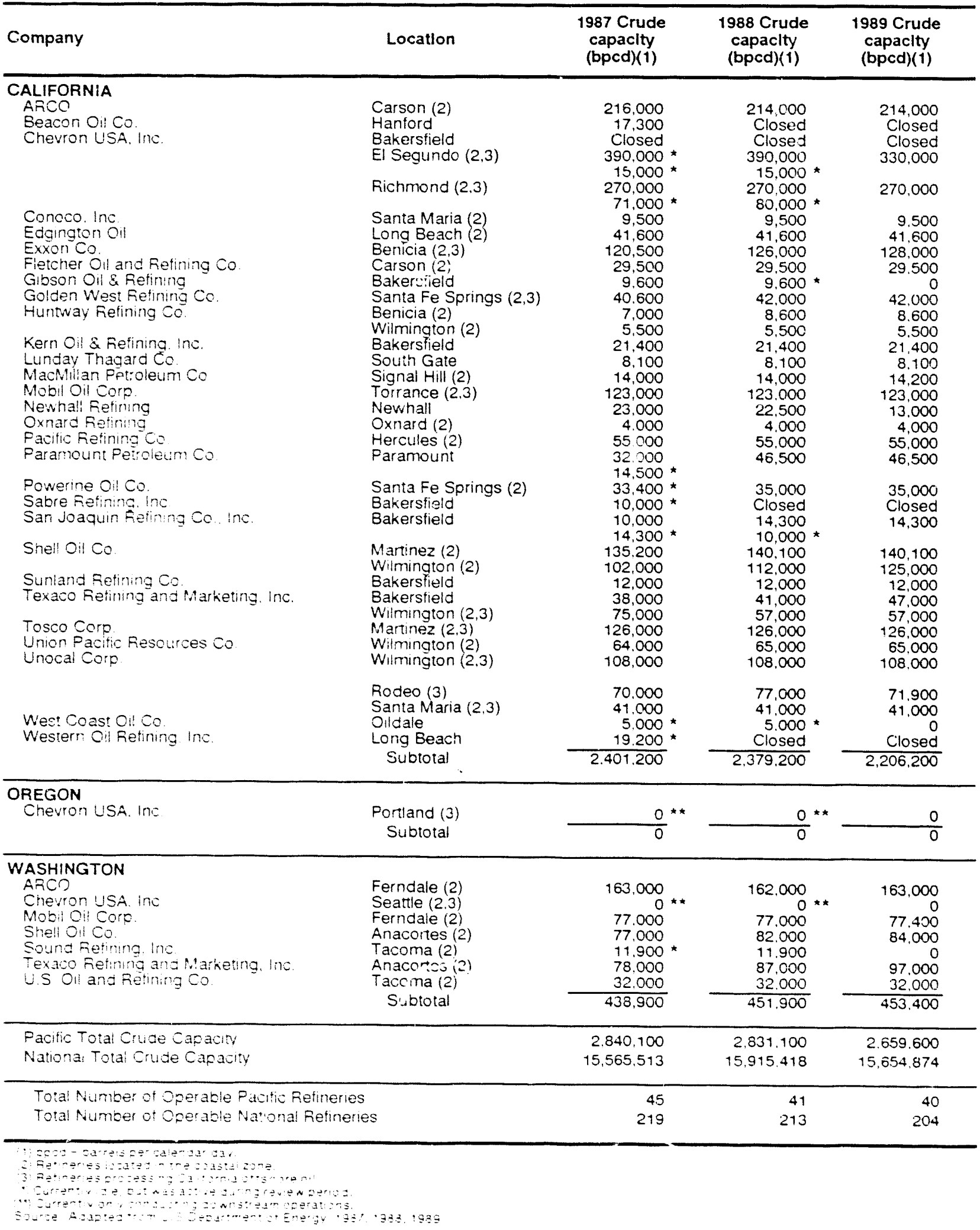




\section{Special Topics Related to the OCS Program}

\section{Offshore Strategic and International Minerals Program}

The Office of Strategic and Intemational Minerals (OSIM) is responsible for develuping policy and coordinating the exploration, development. and recovery of nonenergy minerals from the L.S. Outer Continental Shelf. The OSIM was established (1) to provide overall programmatic direction and policy guidance to Federal off shore nonenergyminerals activities and (2) to facilitate coordination among the Department of the Interior. ciastal States. local governments. and the public sector for timely resolution of issues.

Leasing potential is being evaluated by juint Federal-State task forces in cooperation with the adjacent coastal States. If leasing in deter mined to be conomically feasible, it will then be followed by further resource and envirommental studies as applicable. The tath furces recommend appropriate actions to the Secretary of the Interior and the State Governorts) Federal decisions to proced to lease sales are made by the Secretary with revien and comment from the Governor(s). To ensure protection of the environment. a case-by-case approuch is pursued with environmental reviews and opportunities for public involvement.

Activities and support are currenty fixused in seven areas (see tig. $5-1$, p. 154 ): 11 ) cobalt-rich manganese crusts offishore Hawaii and Johmitun Lland. (2) phosphorites offisore North Carolina 13) heavy-mineral placers and phosphorites otfshore Georgia. 14) sand and gravel and hearymineral placers offethere the Gult Cowe Stater. (5) heary-mineral placers attione Alathat its

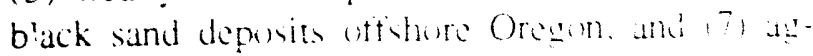

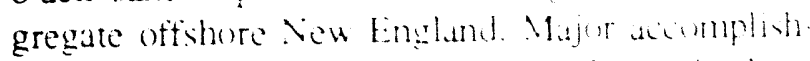
ments, in cooperation with coldal Stuter, in thes seven areds are dicumed in the following
Cobalt-rich Manganese Crusts Offshore Hawaii and Johnston Island.-A new Federal/State of Hawaii cooperative agreement for "Marine Minerals Joint Planning and Review" was tinalized on December 29. 1988. The agreement increased the participation of the State in planning and reviewing of marine minerals activities offshore $\mathrm{Ha}_{\mathrm{a}}$ waii and Johnston Island in coordination with the State on program and policy matters of mutual interest. The agreement established a Joint Planning Arrangement (JPA) with two committees. One is a four-member Cooperative Steering Committec (CSC), and the other is a Coordination Committee (CC) to coordinate project activities and provide technical support to the CSC.

In Decomber lysy. the MMS and State of Hawaii completed the final EIS for the possible leasing of cobalt-rich manganese crusts of fishore Hawaii and Johnston Island. Release of the EIS to the public and a joint Federal/State announcement are anticipated in October 1990.

Phosphorites Offshore North Carolina.The report entitled Economic Feasibility of Mining Phosphorite Deposits of the Continental Shelf A ajacem to North Carolina report was completed by the Federal-State of North Carolina Task Force in May 1988. A Federal Register notice was published concurrent with release of the report asking for public comment. The report and a request for comments were also sent to the American Mining Congress and to all phosphate companies urging their review. These comments were reviewed in a public meeting of the task force on June 15. I9xis, and summarized in a report to the M.MS Direqur on August 15, 198x. On March 3. why. whe state requested that the task force be continued. M1115 and the State agreed to a nocont extension through Decomber 19y(). 


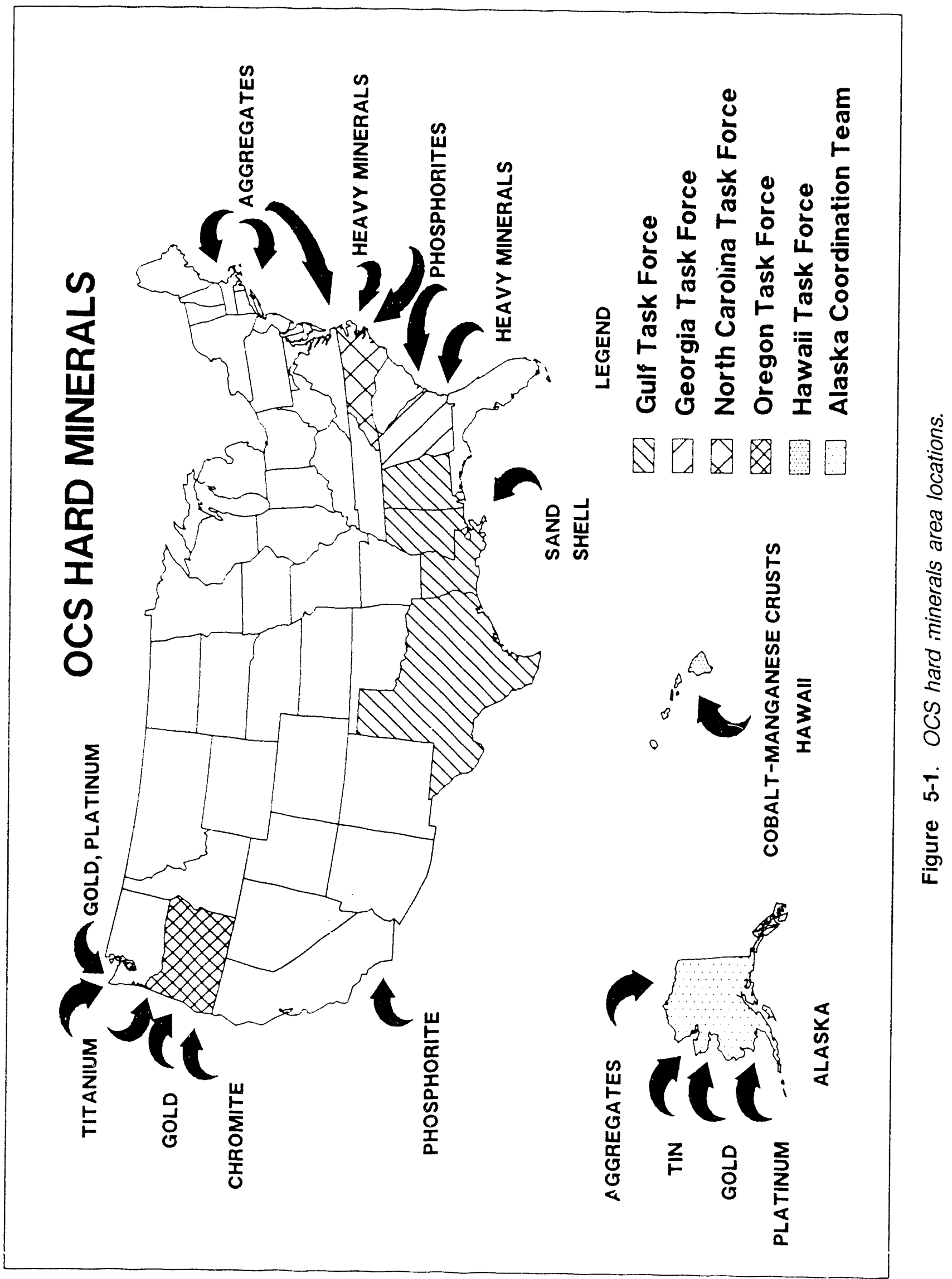


Heavy-Mineral Placers and Phosphorites Offshore Georgia.-The Federal-State of Georgia Task Force completed an economic feasibility study for heavy minerals and phosphorites offshore Georgia. A final report entithed "Resource Assessment Study for Georgia Off shore Minerals" was delivered on July 20, 1988 , and a Federal Register notice requesting public comments on the assessment was published on December 20, 1988. On March 30, 1989, the task force met to assess comments received and to discuss the future direction of the project. Following the March meeting a number of studies were initiated. Preliminary results of these studies were presented at a number of workshops and task force meetings held over the past year. A September 13, 1990 , task force meeting was held to review the results of the completed fieldwork and to discuss at draft proposal by the Georgia Department of Natural Resources. The proposal, reflecting carlier recommendations of the task force, is a scope of work to gather geologic and hydrologic data. Following additional meetings, which are planned for the near future, a final proposal will be submitted to MMS and the State. A turget date of June/July 1991 for the research effort is expected to be included in this proposal.

Sand and Gravel and Heavy-Mineral Placers Offshore the Gulf Coast States.-A joint Federal-Multi-State Task Force was formed in January 1987 by MMS and the States of Alabama, Louisiana, Mississippi, and Texas. The first objective of the Gulf Task Force was to prepare a preliminary assessment of the occurrence and potential of marine minerals located off the coasts of these four States. An economic reconnaissance study began in August 1987. focusing on available data and information, with no fieldwork involved. The reconnaissance study was completed in October $198 x$. and its findings were presented at the Gulf of Mexico Information Transfer Mecting that same month. A final report was provided (1) MMS in March $19 \times 9$ including recommendations for future work. An extension of the cooperative agreement for a 24 -month period was approved on September 7, 1989. The focus is on geologic, engineering, economic, and sand source for beach nourishment and restoration of the Isles Dernieres and nearby Bayou Lafourche shoreline. On August 10, 1990, the Gulf Task Force met at the MMS Regional Office in New Orleans, Louisiana. It was reported that all of the subtasks are on schedule.

Heavy-Mineral Placers Offshore Alaska.-A Federal-State of Alaska Coordination Team was established in February 1988 to examine the resource potential of marine minerals offshore Alaska. As a result of ongoing gold dredging under a State lease and current industry interest, the first focus is an extension of that leasing activity in Norton Sound into Federal waters. On November 29, 1988, a draft EIS was issued for a proposed Norton Sound Lease Sale. Coinciding with the release of the draft EIS, a workshop was held in Anchorage, Alaska, on "Mercury in the Marine Environment." The objective of the workshop was to review current knowledge of mercury levels in seawater, sediments, and organisms, and to discuss related water-quality criteria and health concerns. In May 1989, MMS contracted Battelle Northwest Laboratories to acquire new trace-metal data using state-of-the-art collection and analytical techniques. In September 1989, a decision was made to prepare a second draft EIS using the new information on water quality and trace metals in human hair and to include four stipulations as part of the proposal.

In November 1989, the MMS worked with the State and the Coordination Team to develop a new prelease process. Under the new process, the Director's decision documents consist of a Proposed Action and Altematives Memorandum, and UpdateMemorandum (UDM), and a Decision Memorandum, all of which will constitute a Record of Decision. The Proposed Leasing Notice (PLN) will be sent to the Governor for a 6()-day review at the same time the DEIS is filed with the EPA. A second 3()-day review period subsequent to availability of the preliminary final EIS will also be afforded the Governor. 
The decision meeting on the PL.N and the draft EIS was held on June 5, 199(1. Notices of Avalability for both the draft EIS and the PLN were published in the Federal Register on June 15, 1990 (55 FR 24330). The tinal EIS is scheduled for relcase in December 1990), followed by the Final Leasing Notice in January 1991. The sale date has been rescheduled for March 1991.

Black Sand Deposits Offshore Oregon.-A Federal-State of Oregon Task Force was established on September 19.1988. The initial objectives of the task force were a cursory economic and strategic resource analysis to the extent existing data pernits. and the identification of additional data necessury to provide a detinitive resource assessment and gauge near-tem economic viability. On March i, 1990, the task force released a final report entitled "Preliminary Feasibility Study: Oregon Placer Minerals." On the basis of the reportis findings, the task forec recommended continuation of efforts and proposed limited resource assessment and biological studies of Cape Blance and Gold Beach. On March 6. 1990. the task force met and established a cruise planning commitie to development technical requirements for the work and to develop a work plan budget.

A scientific research cruise began on September 21, 199(1, and ended on Oetuber 3, 1990. Preliminary reports indicate that despite weather and equipment problems, most of the planned studies were accomplished. However, coring was largely unsuccessful, and the lack of data at depth was discouraging.

Aggregate Offshore New England.-An aggregate demand study for the six New England Siates was received by MMS on June 1 , 19y(), trom the New England Governors Conference, Inc., a nomprotit, nompartisan lax exempt corporation composed of the Governors of the six New England States who serve as the Brard of Direchors. The study, which has been approved for funding. will be adminis tered by the conference under a conperative angement wh MMS. The objective of the study is in investigate current and future ag gregate demands within the New England
States to determine if projected needs outpace traditional supplics. Should the study conclude that the projected demand for sand and/or gravel is such that it is likely to outpace the traditional local supplics, a recommendation could be made for a task force to cvaluate onshore supplies as well as offshore deposits and the ability to meet the demand.

Regulations covering marine minerals prospecting, leasing, and operations are being developed sequentially through a multiagency task force with expertise in marine mining, technology, and the environment. The rulemaking process for prospecting regulations began with the publication of an advance notice of proposed rulemaking in December 1984 and concluded with the July 5, 1988, Federal Register notice containing the final rule. Development of leasing and operating regulations began in 1985 and 1987, respectively, and culminated August 18,1988 , with the publication of the proposed regulations in the Federal Register 153 FR 31424 and 53 FR 31442, respec(ively). The public comment period on these rules closed November 2,1988 . The development and finalization of these regulations have been attended by considerable open discussion with industry, academia, environmental groups, and State and Federal government representatives. The offshore Nome, Alaska OCS Mining Program, Norton Sound Lease Sale is the first scheduled to be held under these new regulations.

In addition to its role of policy and coordination for managing the marine mineral resources of the OCS, OSIM has also been principal advisor and information repository fur MMS on international activities. OSIM has provided technical advice on issues specific to the 1982 United Nations Convention on the Law of the Sea and Antarctic and Arctic mineral development. It is expected that the international role of OSIM will expand to better service the needs of MMS. 
For more detailed intomation on the above-mentioned atcivities, or for information on the Offshore Strategic \& International Minerals Program in general, contact Ms. Carolita Kallaur, Program Director, at $(703) 7 \times 7-13(x)$.

\section{Coastal Zone Management Program}

The Coastal Zone Management Act (CZMA) was enacted in 1972 to promote the wise use and management of the vation s coastal resources. It was designed as a voluntary program to encourage the individual States to manage their coastal areas through implementation of federally approved coastal zone management programs (CZMPs). As an incentive to participate in the program, States are given Federal dollars (o) develop and maintain fon a cost-sharing basis) a State program and the ability (1) veto those Federal activities affecting the coastal zone that are not consistent with their State CZMPs. At the Federal level, the CZMP is administered by the Nutional Oceanic \& A tmospheric Administration (NOAA) of the U.S. Department of Commerce.

\section{Coastal Zone Management Act Reauthorization}

In 199(), as part of the Presidential budget reconciliation package (P.L. 5(18), the CZMA was reduthrized through 1995, with amendments. The amendments clarified that all Federal ativities accurring both within and outside the coatul ane are subject to Federal consistency requirements of section $3(17(c)(1)$ of the Act if they affect natural resources, land uses. or water unes in the coural zone. This was contrary to the Supreme Court decision that OCS oil and gas lease sales would not be subject to Federal comsistency under the CZMAA. As federally conducted and tekrally permitted activitien are affected by the amendments. MMS will hate changer in it programs.
Federally Conducted Activities. - The newly reauthorized CZMA broadens the application of consistency to encimpasis a wide range of federally conducted activties taking place both within and outside the coastal zone. altering the statement of effect to include natural resources. The changes were accomplished by the following language in section $307(C)(1)$ of the CZMA:

"Each Federal agency activity within or outside the coastal zone that affects any land or water use or natural resource of the coastal zone shall be carried out in a manner which is consistent to the maximum extent practicable with the enforceable policies of approved State management programs."

Also, the amended CZMA in section $3(17)(C)(1)(C)$ requires that a Consistency Determination be made by MMS and sent to the State no later than 90 days (earlier if possible) before the final approval of the Federal activity unless both the Federal agency and the State agency agree to "different scinedule.

Federally Permitted Activities. - Section $3(1) 7(C)(3)(A$ and $B)$, with the phrase in or outside of the coastal zone, expands the "boundaries" of the coastal zone, which extends the jurisdiction of the State coastal program to cover more federally permitted activities conducted inland and in offshore areas.

Section $3(17(C)(3)(A)$ increases the elements covered by State coustal management plans when referring to federally permitted activities. The statement of effect was revised from "affecting land or water use in the coastal zone" (6) "affecting any land or water use or natural resource of the coastal ane."

Effective Changes in MMS Programs.Changes inherent from the amendments that at fect MMS s administrative programs include the following:

\footnotetext{
- Comsistency determinations for cach coustal State with an approved coantal management program will be required for edeh ( $C S$ leave
} 
sale. Final decisions for upcoming sales may be delayed, as well as receipt of bonuses.

- State involvement in OCS issues - lease sales and permitting - will increase. Coordination with State officials regarding OCS consistency issues will increase.

- MMS regulations and permitting procedures may need to be examined and possibly revised. This may delay regulated activities.

- Appeals on consistency certifications for OCS-related permits may increase because of the changes involving boundaries and the scope of activities subject to consistency review.

Additional CZMA Provisions.-The amended CZMA also includes the following provisions:

- It establishes a Coastal Zone Management Fund consisting of Coastal Energy Impact Progiam loan repayments from which the Secretary of Commerce will pay for the Federal administrative costs of the program and will fund special projects, emergency site assistance, and other discretionary coastal zone management activities.

- It reinstates program development grants by authorizing the Secretary of Commerce to provide assistance to a State for developing a CZM program.

- It encourages each coastal State, under a Coastal Zone Enhancement Grants Program, to continually improve its CZM program in one or more of eight identified areas: (1) coastal wetlands management and protection; (2) natural hazards management (including potential sea nad Great Lake level rise); (3) public access improvements; (4) reduction of marine debris; (5) assessment of cumulative and secondary impacts of coastal growth and development; (6) spe- cial area management planning; (7) ocean resource planning; and (8) siting of coastal energy and Government facilities.

- It authorizes the Secretary of the Interior to make annual "Walter B. Jones" achievement awards to recognize individuals, local governments, and graduate students for outstanding accomplishments in the field of coastal zone management. It authorizes these appropriations for 5 years at increased levels.

- It establishes (in the subtitle of the amended CZMA) a Coastal Nonpoint Pollution Control Program that will require each coastal State to develop a program - to be implemented through the CZMA and section 319 of the Clean Water Act - to protect coastal waters from nonpoint pollution from adjacent coastal land uses.

\section{Consistency Certifications - Recent and Pending}

Even though the consistency provisions relating to permits were not changed in the newly reauthorized CZMA, appeals on consistency certifications for OCS-related permits are likely to increase because of changes concerning boundaries and the scope of activities subject to consistency consideration. The following is a status report on recent and pending consistency certification appeals in the MMS s OCS regions:

\section{Recent Consistency Appeal Decisions}

\section{Alaska Region: Amoco's Galahad Prospect}

- In March 1989, Alaska denied consistency for Amoco`s Galahad Prospect Exploration Plan, citing noncompliance with the State's seasonal drilling restriction policy and the need for additional bowhead whale monitoring requirements.

- The OCS leases comprising the Galahad Prospect were awarded to Amoco, Shell Western Exploration \& Production and 
Union Oil Company of California in lease sale 97 (Beaufort Sea). Sale 97 was the fourth sale held in the Beaufort Sea and the first sale not to contain a stipulation that prohibited drilling during the bowhead whale migration period (a seasonal drilling restriction).

- On July 20, 1990, the Department of Commerce found Amoco's Exploration Plan to be consistent with the objectives and purposes of the CZMA. As a result, Federal agencies may issue permits allowing Amoco to conduct its proposed activity.

\section{Pacific Region: Chevron 525}

- In June 1988, the California Coastal Commission (CCC) denied consistency for Chevron's Exploration Plan citing concerns for air quality.

- Lease OCS-P 0525 was awarded to Chevron and Champlin Petroleum Company as part of lease sale 80 (Southern California) - a sale that the CCC adamantly opposed.

- On October 29, 1990, the Department of Commerce upheld the CCC consistency denial citing that there are reasonable alternatives available that would permit the activity to be conducted in a manner consistent with the management program; therefore, Chevron's Exploration Plan is not consistent with purposes and objectives of the CZMA. The "reasonable altemative" the Department of Commerce refers to involves air-quality mitigation, specifically the availability of offsets and drilling rigs with a "cleaner" Caterpillar engine. Due to denial of consistency, MMS is prohibited from approving Chevron's activity. In addition, given the denial and the recent Clean Air Act legislation, Chevron can now accept alternatives recommended by the State of California or negotiate new air-quality terms.

\section{Pending Consistency Certification Appeals}

\section{Atlantic Region}

- In July 1990, North Carolina denied consistency for Mobil's NPDES permit citing Mobil's failure to provide essential information that would allow the State to conduct a proper consistency review. The Department of Commerce plans to hold a public hearing on December 13, 1990. The Department of the Interior and MMS plan to submit comments by the December 27, 1990, close of the comment period.

\section{Gulf of Mexico Region}

- In November and December 1988, Florida denied consistency for Unocal's and Mobil's Exploration Plans, respectively, citing insufficient environmental baseline information. The blocks involved are located south of 26 degrees N. latitude. The Department of Commerce held a public hearing on these appeals for September 29, 1989, in Key West, Florida, and hopes to issue decisions on these appeals in the winter of 1990.

\section{$\underline{\text { Pacific Region }}$}

- In June 1988, the California Coastal Commission (CCC) denied consistency for Conoco's Exploration Plan, citing concems for air quality, biological impacts, and commercial fishing conflicts. This appeal is for a Sale 80 (Southem California) lease - a sale that the CCC adamantly opposed.

- In September 1990, Conoco petitioned for and was granted a stay of their appeal until September 21,1991 . This stay would enable Conoco and partners to evaluate plans in light of market conditions, permitting, and budgetary constraints, and new exploration opportunities. 


\section{Rigs-to-Reefs Program}

The presence of offshore oil and gas platforms (or rigs) in the Gulf of Mexico for the past 40 years has provided an important manmade resource to the area in the form of hard substrate for biological organisms. The realization of the value of these rigs, while in place, to commercial and recreational fishing has prompted Federal, State, and private interests to consider expanded use of these rigs as artificial rects.

The Secretary of the Department of Commere issued the National Artificial Reef Plan during November 1985 in accordance with a mandate from the National Fishing Enhancement Act of 1984 (33 U.S.C. 2103). This pian sets out national policy regarding artificial reefs, including obsolete oil and gas structures, and provides guidance to government and private concerns regarding the design, siting, permitting, construction, and management of artificial reefs. The plan specifically encourages the development of State and local artificial recf plans that incorporate specific criteria that account for local conditions. MMS established a policy encouraging the use of obsolete oil and gas structures as artificial reefs in response to the plan and law.

In support of the National Artificial Reef Plan and Agency policy, the MMS Gulf of Mexico Regional Office did the following:

- published a report on rigs-to-reefs development options (Reggio, 1987);

- organized, supported, and co-chaired a special session on rigs-to-recfs at the Fourth International Conference on Artificial Habitats for Fisheries (Reggio, 1989);

- advised Gulf Coast States on the development of artificial reefs where obsolete oil and gas structures were under consideration for reef development projects;
- presented a paper on rigs-to-reefis at the American Fisheries Socicty (AFS)/MMS Special Symposium on OCS Fishery Management Conflicts, held in Anchorage, Alaska, on September 7-8, 1989:

- agreed to organize and chair a session on offshore structures for the Fifth International Conference on Artificial Habitats for Fisheries scheduled for November 1991 in Long Bcach, California;

- monitored a special task force of Gulf States Marine Fisheries Commission; and

- has, on behalf of the program, active MMS dive teams in cooperation with the Louisiana State University Coastal Fishcries Institute.

In 1988, the Subcommittec on Safety of Navigation of the International Maritime Organization (IMO) endorsed a new set of "Guidelines and Standards for the Removal of Offshore Installations and Structures on the Continental Shelf and in the Exclusive Economic Zone." These platform decommis-sioning guidelines require removal of small platforms - 4,0(0)-tons or less - in up to 75-foot waters, with exceptions for structures used as artificial reefs. This is the first time an intemational guideline on platform decommissioning explicitly provided for the creation of artificial reefs to enhance living marine resources when in line with a country's established policies. These decommissioning guidelines were issued worldwide in an advisory circular and was approved by the IMO Assembly in the fall of 1989.

Each of the coastal States in the Gulf of Mexico Region is active in developing local plans and in permitting and siting artificial recfs. Because of the maturity of this oil and gas province, numerous related structures are becoming obsolete. Figure 5-2 (p. 161) shows the number of oil and gas structures removed in the Gulf of Mexico reached an all time high of 102 in 1988. This high level of removals 
continued into 1989, with $10($ ) platfonms removed. As of October 31, 1990, there had already been 6y structures removed from the Gulf of Mexico. To put these numbers in perspective, an average of 35 structures per year were removed in the Gulf of Mexico from 1980 to 1987. This high level of removals is expected to increase throughout the $1990 \% \mathrm{~s}$. In accordance with domestic and intemational regulations, inactive structures must be remeved. Currently, most of these structures are removed from the seabed and hauled ashore for salvage as scrap. In recent years, however, the value of these structures as artificial habitat for marine life has been widely recognized. Accordingly, a significant focus of many of the Gulf of Mexico Region coastal States" artificial reef plans involve the siting of oil and gas structures. Table 5-1 (p. 162) lists existing and permitted rigs-toreefs projects on the Gulf of Mexico OCS.
In Louisiana, the Louisiana Fishing Enhancement Act (Act 100) was signed into law on July 1, 1986. This law established a State Artificial Reef Program and required the development of a plan covering both State and Federal waters of the Louisiana coast. The plan, approved by the State Legislature in June 1987 and since amended, has established nine artificial reef planning areas on the OCS, offshore Louisiana.

Since the approval of the State Artificial Reef Program, four artificial reef sites have been established using materials donated by five off shore operators. The first, named Shelter, was made from an eight-pile platform jacket, or main support. owned by Oxy Corporation (formerly Cities Service Oil and Gas Corporation) and is located in

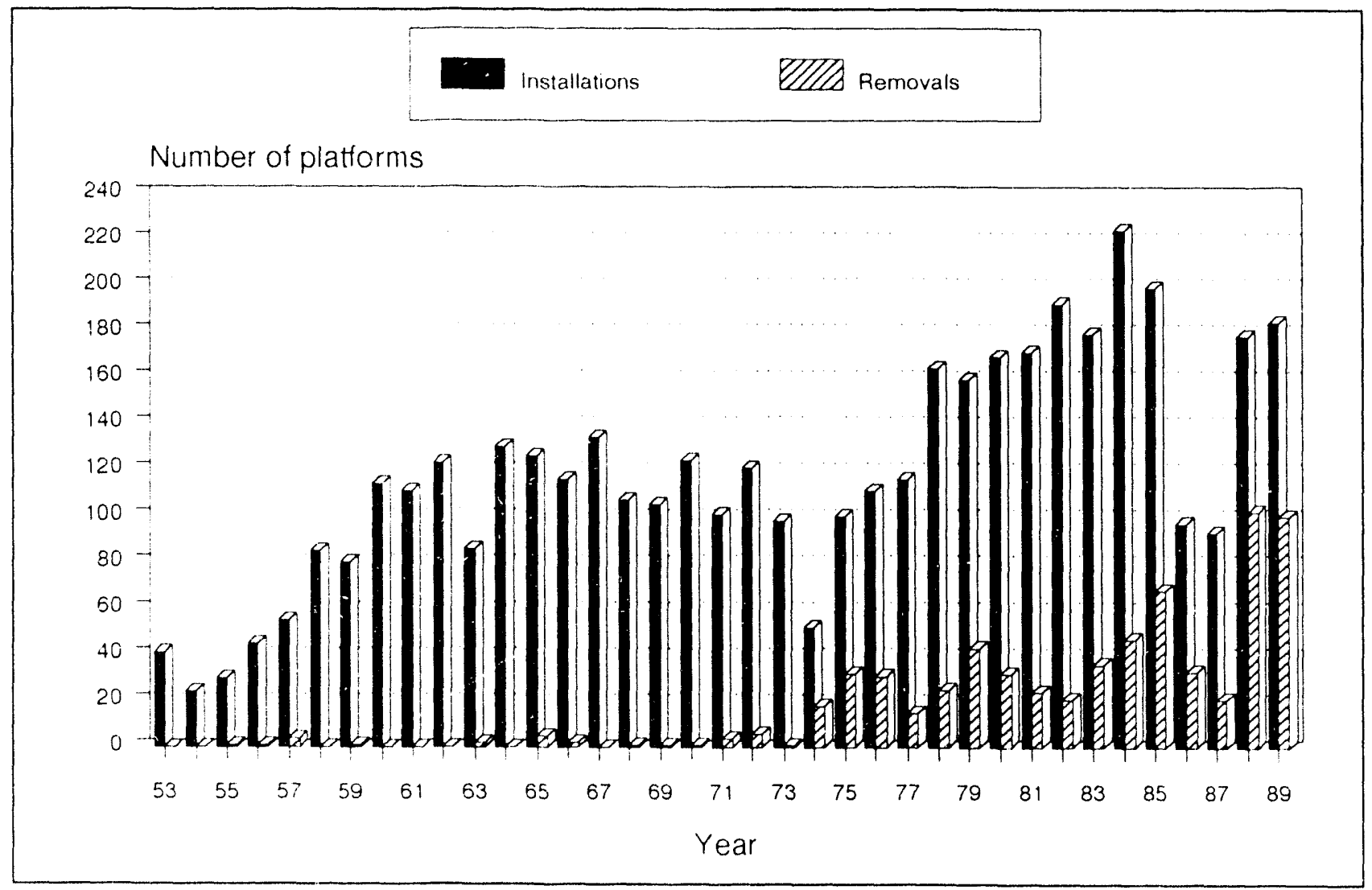

Figure 5-2. Yearly installations and removals of offshore production platforms on the Gulf of Mexico OCS, 1953-89. 
Table 5-1. Existing and permitted rigs-to-reefs projects on the Gulf of Miexico OCS through October 1990

\begin{tabular}{|c|c|c|c|c|c|c|c|}
\hline Reef Identiflcation & $\begin{array}{l}\text { Plannlng } \\
\text { area }\end{array}$ & $\begin{array}{c}\text { Reef } \\
\text { location (2) }\end{array}$ & $\begin{array}{l}\text { Water } \\
\text { depth } \\
\text { (tt) }\end{array}$ & $\begin{array}{l}\text { Distance } \\
\text { to shore } \\
\text { (miles) }\end{array}$ & $\begin{array}{l}\text { Former } \\
\text { owner or } \\
\text { donor }\end{array}$ & $\begin{array}{c}\text { Reef } \\
\text { sponsor }\end{array}$ & $\begin{array}{l}\text { Year } \\
\text { added }\end{array}$ \\
\hline Topper III Reef (1) & Western & $\begin{array}{l}\text { High Island } 2 \\
\text { A-471 }\end{array}$ & 196 & 89 & Zapata & Mobil Oil & 1977 \\
\hline Tower S Reef & Eastern & $\begin{array}{l}\text { Apalachicola } \\
686\end{array}$ & 126 & 25 & Exxon & $\begin{array}{l}\text { Florida Dept. of } \\
\text { Natural Resources }\end{array}$ & 1979 \\
\hline Arco Reef (1) & Western & $\begin{array}{l}\text { North Padre Is. } \\
985 \text { and } 980\end{array}$ & 97 & 18 & $\begin{array}{l}\text { Dixilyn } \\
\text { Field } 81\end{array}$ & Arco & 1981 \\
\hline Pensacola Reef & Eastern & $\begin{array}{l}\text { Pensacola } \\
983\end{array}$ & 175 & 22 & Tenneco & $\begin{array}{l}\text { Florida Dept. of } \\
\text { Natural Resources }\end{array}$ & 1982 \\
\hline Marathon Reef & Eastern & $\begin{array}{l}\text { Destin Dome } \\
486\end{array}$ & 240 & 50 & Marathon & $\begin{array}{l}\text { Alabama Dept. of } \\
\text { Conservation and } \\
\text { Natural Resources }\end{array}$ & 1983 \\
\hline Penrod Reef (1) & Western & $\begin{array}{l}\text { Matagorda Is. } \\
657\end{array}$ & 68 & 12 & Penrod & Penrod & 1983 \\
\hline \multicolumn{8}{|l|}{ Panama City Reefs } \\
\hline $\begin{array}{l}\text { Stage } 1 \\
\text { Stage } 2\end{array}$ & $\begin{array}{l}\text { Eastern } \\
\text { Eastern }\end{array}$ & $\begin{array}{l}\text { Pensacola } 1006 \\
\text { State waters }\end{array}$ & $\begin{array}{r}100 \\
60\end{array}$ & $\begin{array}{c}12 \\
3\end{array}$ & $\begin{array}{l}\text { U.S. Navy } \\
\text { U.S. Navy }\end{array}$ & $\begin{array}{l}\text { Bay County, Florida } \\
\text { Bay County, Florida }\end{array}$ & $\begin{array}{l}1984 \\
1984\end{array}$ \\
\hline Tenneco Reef & $\begin{array}{l}\text { South } \\
\text { Atlantic (3) }\end{array}$ & Stale waters & $1-400$ & 1.5 & Tenneco & $\begin{array}{l}\text { Florida Dept. of } \\
\text { Natural Resources }\end{array}$ & 1985 \\
\hline Shelter Reef & Central & $\begin{array}{l}\text { South Marsh is. } \\
146\end{array}$ & 240 & 90 & $\begin{array}{l}\text { Cities } \\
\text { Service }\end{array}$ & $\begin{array}{l}\text { Louisiana Dept of } \\
\text { Wildlife \& Fisheries }\end{array}$ & 1987 \\
\hline Snapper & Central & $\begin{array}{l}\text { South Timbalier } \\
128\end{array}$ & 104 & 28 & $\begin{array}{l}\text { Chevron } \\
\text { U.S.A. }\end{array}$ & $\begin{array}{l}\text { Louisiana Dept. of } \\
\text { Wildlife \& Fisheries }\end{array}$ & 1988 \\
\hline Angel (4) & Central & $\begin{array}{l}\text { West Cameron } \\
616\end{array}$ & 310 & 120 & $\begin{array}{l}\text { Exxon U.S.A.I } \\
\text { Mobil Exp. \& } \\
\text { Prod. }\end{array}$ & $\begin{array}{l}\text { Louisiana Dept. of } \\
\text { Wildlife \& Fisheries }\end{array}$ & 1988 \\
\hline Angel & Central & $\begin{array}{l}\text { West Cameron } \\
616\end{array}$ & 310 & 120 & $\begin{array}{l}\text { Exxon U.S.A./ } \\
\text { Mobil Exp. \& } \\
\text { Prod./CNG }\end{array}$ & $\begin{array}{l}\text { Louisiana Dept. of } \\
\text { Wildlife \& Fisheries }\end{array}$ & 1990 \\
\hline Snapper & Central & $\begin{array}{l}\text { South Timbalier } \\
128\end{array}$ & 104 & 28 & Chevron & $\begin{array}{l}\text { Louisiana Dept. of } \\
\text { Wildlife \& Fisheries }\end{array}$ & 1990 \\
\hline Shelter Reef & Central & $\begin{array}{l}\text { South Marsh } \\
\text { Island } 146\end{array}$ & 240 & 90 & $C N G$ & $\begin{array}{l}\text { Louisiana Dept, of } \\
\text { Wildlife \& Fisheries }\end{array}$ & 1990 \\
\hline Volcano Reef & Central & $\begin{array}{l}\text { Ship Shoal } \\
320\end{array}$ & 330 & 80 & CNG & $\begin{array}{l}\text { Louisiana Dept. of } \\
\text { Wildlife \& Fisheries }\end{array}$ & 1990 \\
\hline (Unnamed) & Eastern & $\begin{array}{l}\text { Destin Dome } \\
576\end{array}$ & 430 & 60 & Chevron & $\begin{array}{l}\text { Alabama Dept. of } \\
\text { Conserv. \& Natural. }\end{array}$ & 1990 \\
\hline (Unnamed) & Western & $\begin{array}{l}\text { High Island } \\
\text { South Addition } 492\end{array}$ & $2^{200}$ & 85 & TXP & $\begin{array}{l}\text { Texas Parks \& } \\
\text { Wildlife }\end{array}$ & 1990 \\
\hline
\end{tabular}


South Marsh Island block 146. This structure was toppled, in place, in 238 feet $(73 \mathrm{~m})$ of water on October $29,1987$.

On September 26, 1988, an eight-pile platform (jacket and deck) and two three-pile auxiliary platforms were donated to the State by Chevron U.S.A., for development of the Snapper reef. These platforms were toppled in 104 feet $(32 \mathrm{~m})$ of water in South Timbalier block 128. Chevron U.S.A. donated a portion of its savings $(\$ 50 .(0)(0)$ to the State Artificial Trust Fund.

In November 1988, development of the third reef, the Angel reef, was initiated when two platforms were donated to the State along with $\$ 25(0,0)(0)$ by Exxon Co. U.S.A. Later in 1988. Mobil Exploration \& Producing donated a third platform, along with $\$ 50,000$, to enhance the recf. Since the structures were not located within an approved plinning area, the two companies had to transport and relocate them from offshore Texas to offshore Louisiand. Exxon had to tow its two structures over 25 miles to the West Cameron Artificial Reet Plamning Arca, where it was coppled on an Exxon lease. Mobil transported its structure over 200 miles from a location off of Corpus Christi, Texas, to a Mobil lease within the reef permit area.

In May of 1989, Texas enacted a new artificial reef law calling for an artificial reef plan advisory council and trust fund that will facilitate the development of a rigs-to-reef program off Texas similar to the one under development off the coast of Louisiana. A draft plan was recently completed, and the State sponsored it's first rigs-to-rectis project on High Island block A-49Z on January 25,1990 . The reef is located 8.5 miles offshore of Galveston, Texas, in 200 feet of water. The rig and $\$ 35,0(0)$ was donated by TXP.

For further information on the various rigs16-rects projects nationwide, sec the Additional Readings section at the end of this chapter or contact the following agency:
Artificial Reef Development Center Sport Fishing Institute 1010 Massachusetts Ave., NW., Suite 100 Washington, DC 20001

(202) $898-0770$

\section{Oil Spills}

Oil spills are generally considered the greatest environmental concern regarding off shore oil and gas activities. Although oil spills are statistically very unlikely to occur, when they do occur, their effects can be devastating to local aquatic (fish, fowl, etc.) life and local cconomies. Oil spills are also front-page news events. Most people do not make a distinction between oil spills resulting from domestic OCS oil activities and oil spills resulting from the tanker importation of foreign crude oil. These two sources of spills are very distinct: domestic OCS oil activities are highly regulated by the U.S. Government, as well as State and local governments; tanker importation of foreign crude oil is primarily governed by less stringent international protocols with some local control.

Offshore oil and gas activities include exploration and development drilling, production, transferring and loading operations, and transporting (both by tanker and pipeline). All these phases have a degree of oil-spill risk associated with them. Almost all OCS production is transported by pipeline to shore for processing, refining, and distributing to market. Generally, OCS production involving tankers is temporary, until field size and production levcls are determined and/or pipclines and onshore processing facilities are permitted and installed. In some remote frontier OCS areas tankers may be considered on a long-term basis because of the great distances and inhospitable conditions, such as in remote parts of Alaska. No production has yet occurred in such areas.

MMS considers pipelines environmentally preferable to tankers, and generally pipelines are also economically preferable. Advantages of pipelines over tankers include reduced air 
emissions, reduced vessel traffic in port and offshore, reduced port congestion and competition for port facilities, and reduced risk of oil spills. Tankers do, however, offer greater flexibility of oil delivery location, and are generally available inmediately, without construction time. As a result of these factors, MMS and most State policies have encouraged the use of pipelines over tankers for the transport of OCS proJuced oil. Stipulations have been developed and attached to many OCS leases stating the Government's position favoring pipelines over tanker transportation. The Alaska stipulation regarding the transportation of hydrocarbon products is presented and discussed in Chapter 4 (p. 138 ).

\section{Federal Oil-Spill Control and Cleanup Mechanisms}

The Federal Government has a national response system for oil and hazardous substance pills. The legal authority comes from the Clean Water Act (CWA), which establishes a Federal oil-spill fund, calls for national and regional response teams and contingency plans, and the Comprehensive Environmental Response, Compensation, and Liability Act (CERCLA), which establishes the Superfund for Federal responses and cleanups of hazardous substances.

The primary component of the Federal response system is the National Oil and Hazardous Substances Pollution Contingency Plan or simply the National Contingency Plan (NCP). The NCP establishes a National Response Cenler, a National Response Team (NRT), Regional Response Teams (RRT's), and On-Scene Coordinators (OSC's). The Environmental Protection Agency chairs the NRT, co-chairs the RRT's. and provides predesignated OSC's for inland spills. The U.S. Coast Guard co-chairs the NRT and the RRT's, and provides predesignated OSC"s for for coastal spills including these on the OCS. The Coast Guard also operates the National Response Center, and the National, Pacific, and Gulf of Mexico Strike
Teams, which are trained and equipped to respond to major marine spills. The names, addresses, and telephone numbers of the National Response Center and the members of the national and regional teams are listed in the MMS OCS Directory (OCS Information Report MMS 9()-0064). For further information regarding the national and regional response teams, contact the following office:

National Response Team

Altn: LCDR Harry E. Schulty.

U.S. Coast Guard Headquanters, G-MER-2

2100 2nd St., SW.

Washington, D.C. 20593-()()()1

Telephone: (202) 267-2616

\section{Federal Oil-Spill Research Programs}

The MMS has a strict set of rules governing all oil, gas, and sulphur exploration, development, and production on the OCS. These rules were consolidated for all the OCS regions on April 1, 1988, and published in the Federal Register (53 FR 10596), modifying the existing regulations (30) CFR 250). (See p. 85 for more information on the Consolidated Offshore $O p$ erating $R$ ules.) These rules include oil-spill prevention, contingency planning, and control requirements. Lessees and operators are required to submit detailed oil-spill contingency plans, that identify cleanup strategies, sensitive coastal resources, and the resources to be employed during a spill. These plans are submitted to MMS for approval and review. The MMS obtains comments and recommendations from the U.S. Coast Guard about these plans. Plans are tested with both announced and unannounced oil-spill drills.

In addition to the MMS operating rules, MMS administers a research program designed to improve oil-spill response capabilities. The U.S. Coast Guard, the American Petroleum Institute, and Environment Canada are involved jointly with MMS on some of these efforts. Current oil-spill research projects include remote-sensing and equipment testing and evaluation for skimming systems, containment 
booms, chemical treatments, in-situ burning, beach cleaning, and improving response documentation and decision manuals. More than $\$ 6$ million has been earmarked for such projects for 1986-92.

\section{Oil and Hazardous Materials Simulated Environmental Test Tank}

The Oil \& Hazardous Materials Simulated Environmental Test Tank (OHMSETT) facility, located in Leonardo, New Jersey, has recently been reactivated and is being administered by the MMS. Research activities are expected to resume in carly 1991.

OHMSETT is an open-air saltwater test tank holding $2.6 \mathrm{Mgal}$ of water and measuring 625 ft $\times 6.5 \mathrm{ft} \times 11 \mathrm{ft}$. The facility is used to test oil-spill cleanup equipment (i.e., brooms, skimmers, and chemicals) and strategies under realistically simulated environmental conditions. The facility is more fully described in the $A t$ lantic Update: July 1986-June 1990 (OCS Information Report MMS 9()-()(06()).

\section{Technology Assessment \& Research Program}

The MMS Technology Assessment \& Research (TAR) Program assesses safety and pollution prevention technologies. These studies promote an enginecring dialogue between industry, academia, and MMS personnel. The research involves well control (blowout prevention), structural adequacy/safety of offshore structures such as platforms and pipelines, and pollution prevention equipment and procedures for offshore operations. The TAR currently administers about 3.5 active projects at universities, private companies, and government laboratories. Many of these are (o)-sponsored with industry or other government agencies. For further information contact the following office:
Minerals Management Service, MS 48(0)

Technology Assessment \& Rescarch Branch

381 Elden St.

Herndon, VA 22070)-4817

Telephonc: (70)3) $7 \times 7.1559$ or (FTS) 393.1559

\section{Oil Industry Oil-Spill Cooperatives}

For many years oil and shipping companies have pooled their resources to form oil-spill cleanup cooperatives. These co-ops often supplement oil-spill-response equipment already existing at the site of the operation, either transferring and loading facilities in-port, or at offshore oil rigs, and that equipment maintained by the Coast Guard. The co-ops are usually dedicated to oil-spill response, with 24 hour per day capabilities, employing highly trained specialists and state-of-the-art equipment. When needed, the co-ops will bring in contractor assistance. A list of the co-ops is also presented in the OCS Directory (OCS Information Report MMS 90-(0)64).

\section{Oil-Spill Legislation and Recommendations}

\section{Federal Comprehensive Oil Pollution Act of 1990}

For approximately 15 years, Congress has debated the need for a comprehensive oil-spill liability and compensation bill. New impetus for such a bill came with the Exxon Valdez oil spill, which occurred on March 24, 1989. On August 4, 1989, the U.S. Senate unanimously passed (99-()) legislation for oil-spill liability and compenation. On November 9, 1989, the U.S. House of Representatives also passed (279-143) parallel legislation.

On July 26, 1990, again after much debate, a House-Senate conference committee agreed on a bill reconciling the differences between the Senate and House bills. The bill is amed 
at preventing, cleaning-up, establishing liability for, and compensating the victims of oil spills. The bill establishes unlimited liabilty if the spill is a result of gross negligence, willtul misconduct, or the violation of any Federal operating or safety standard. The agreement includes the following liability levels: $\$ 1,200$ per vessel ton for ship owners (formerly $\$ 150$ per vessel ton); $\$ 75$ million plus unlimited removal costs for offshore facilities; and $\$ 350$ million for onshore facilities and deep-water ports.

The bill also establishes the uses for a $\$ 1$ billion oil-spill fund, to come from a 5-cents-per-barrel tax on oil. The fund would be used for oil-spill cleanup and compensation to victims when liabiiity limits are reached, when the spiller is unknown, or if the spiller and the injured party cannot reach an agreement within 60 days.

The bill also has provisions for improving navigational safety in the Prince William Sound, Alaska, the site of the Exron Valdez spill, establishing an oil-spill pollution research program, and making changes to the Trans-Alaska Pipeline System. The use of double hulls on oil tankers entering U.S. ports will be required beginning 1995 for new tankers, and by 2010 for old tankers. In addition, the bill includes requirements for drug and alcohol testing of tanker crews, allows for States to have stricter oil-spill liability standards, and creates Coast Guard oil-spill cleanup units around the country. Even though initially opposed by the President, a provision imposing a l-year moratorium (ending with the fiscal year September 30, 1991) on oil and gas activities offshore North Carolina was added.

On August 3, 1990, the U.S. Senate approved the Conference Report by a $99-0$ vote. On August 4, 1990, the U.S. House of Representatives approved the Conference Report by a $360-0$ vote. clearing the bill for the President. The bill was sent to the White House and was signed by the President on August 18, 1990, despite his initial opposition to the North Carolina drilling moratorium. fice:

For further information contact the following of-

Office of Representative Walter B. Jones

Chaiman, Merchant Marine \& Fisheries Committee

Longworth House Office Bldg., Room 1334

Washington, D.C. 20515

Telephone: (202) 225-4047

\section{Regional//nternational Oil-Spill Legislation}

On July 25, 1990, the States-British Columbia Task Force agreed to a West Coast oil-spill-prevention plan. The task force included representatives from Alaska, Washington, Oregon, Califormia, and British Columbia. The public comment period will continue until September 1990. The task force will present their recommendations to the Coast Guard, the State legislatures, and industry groups in each region. It plans to meet and update the plan annually, as well as conduct spill drills. The regional plan was initiated by Washington and British Columbia 16 months after the Nestucca spill. After the Exxon Valdez spill, the other States joined the effort. The plan includes a listing of all the oil-spill equip. ment available on the West Coast.

\section{State Oil-Spill Legislation}

The Florida State Legislature extended the ban on all offshore oil and gas activities in State waters during the 1990 legislative session. The nrevious legislation liad exempted such a ban from $26^{\prime} \mathrm{N}$. latitude on the gulf coast of Florida and from $: 7^{\circ} \mathrm{N}$. latitude on the Atlantic Coast of Florida. The Florida OilSpill Response Task Force, established in 1989, submitted its report on February 1, 1990. to the legislature. In 1990, implementation of their recommendations began, including funding for additional oil-spill booms and skim. mers for the major Florida ports, and an oil-spill-response training program. The maximum liability for spills was increased from 
$\$ 25$ million to $\$ 50$ million under the Coastal Protection Trust Fund with a 2-cents-per-barrel excise tax.

In the winter of 1990 , the State of Florida with the U.S. Coast Guard and the Intemational Maritime Organization developed "avoidance zones" - areas to be by-passed by oil tankers, including a 10 -mile buffer zone around the Florida Keys. This moves the tanker lanes further from sensitive coastal areas, reducing the risk of damage from offshore oil spills. The State of Florida has also commissioned a study to evaluate the effects to the shipping industry of moving the shipping lanes still further offshore.

Louisiana Govemor Buddy Roemer issued an executive order on July 23, 1990, creating a special cummission to draw up an oil-spill prevention and cleanup plan for the State.

The Texas Water Commission recommended in July 1990 that the Texas Govemor conduct an economic feasibility study of an offshore oil port similar to the Louisiana Offshore Oil Port (LOOP). It is presumed that such a facility would reduce the risk of oil spills nearshore. In August 1990, a special advisory committee to Texas Govemor Bill Clements called for the State Legislature to enact an oil-spill cleanup bill that includes a Spill Response Fund from a 2-cents-per-barrel tax on crude oil being moved through Texas Gulf Coast ports.

The Sixteenth Legislature of the State of Alaska adopted major legislation in reponse to the the oil spill in Prince William Sound. In the first session (1989), the legislature

- imposed a 5-cents-per-barrel conservation surcharge on oil coming through the Trans-Alaska Pipeline to fund the Oil and Hazardous Substancie Release Response Fund;

- required the State Department of Environmental Conservation (DEC) to establish a Statewide and r.egional Oil-Spill and Hazardous Substance Contingency Plan and to review and approve oil discharge contingency plans submitted by operators of oil terminal facilities, offshore exploration and production facilities, and oil barges and tankers;

- established a special State office to respond to oil spills in cases where industry cannot and created a volunteer corps to fight oil spills;

- increased civil penalties for crude oil discharges and made those who fail to respond to a discharge jointly and severally liable for the civil penalties assessed against the discharger, and

- prevented oil companies from decucting the cost of oil-spill cleanup activities from State severance taxes.

The second session (1990) of the Alaska Legislature enacted additional oil-related legislation.

- They established a Citizens' Oversight Council as a watchdog of State and Federal agencies to ensure that those with responsibilities for prevention of and response to oil spills are carrying out their duties. The Council must file an annual report to the legislature and governor and recommend appropriate policies and actions to prevent releases of oil and other hazardous substances.

- The set strict cleanup and financial liability standards. In addition, no oil terminal facility, offshore exploration or production facility, nor an oil tanker or barge, can operate without an approved prevention and contingency plan that has been properly implemented. Those with approved plans must maintain sufficient equipment, personnel, and resources to clean up a realistic maximum oil spill within 72 hours.

The Alaska Legislature also

- set rinancial responsibility limits,

- authorized DEC to participate in examinations and to survey non-crude terminal facilities or $5,000-10,000$ barrels, and 
- required DEC to study and make recommendations to the legislature concerning oil-discharge-reponse capabilities necessary for noncrude tank vessels and barges.

In other legislation, the State

- created a State Emergency Response Commission to prepare a statewide master oil and hazardous substance discharge and prevention contingency plan,

- established tougher criminal penalties for negligent operation of oil tankers, and

- raised corporate fines for negligence in oil spills.

\section{County Oi-Spill Legislation}

The Santa Barbara County. Califomia, Resource Management Department's Energy Division adopted an ordinance on November 21, 1989, and approved guidelines for it on June 5, 1990, ensuring that in the event of an oil spill, "sufficient rescurces are available to provide adequate cleanup and res:oration of the affected resources to prespill conditions." This requirement applies to tankers using marine ternina's or marine teminal operations. The ordinance refulires that all operators and users of oil facilities in the county demonstrate the required level of financial responsibility prior to any transportation, transfer, or hadulling of oil in the county.

\section{Additional Readings}

Mustia ()il Spill Comimission. August 1989. Tinenty-four How chromology of livents Following the circunding of

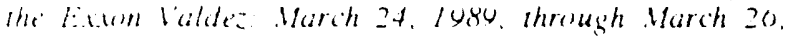
ivisu zo p.

American Pemoleum Institute. Junc l984. Task lore Re'pent on ( )il spills on p.

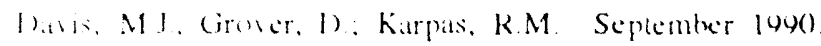

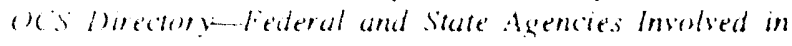
lhe (later (imtinental shelf oil and fias Propram. ()S

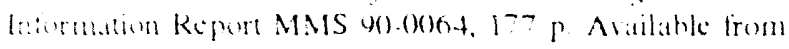

Minerals Management Service, Document Distribution Center. MS 4530, 381 Elden St., Herndon, VA 22070, celephone (703) 787-1080.

Gould, G.J., Karpas, R.M., and Slitor, D.L. 1990. Alaska Update: September 1988-January 1990. Outer Continental Shelf Oil and Gas Activities. OCS Information Report MMS 90-0012,82 p. Available from Minerals Management Service, OCS Information Program, MS 4610,381 Elden St., Herndon, VA 22070, telephone (703) $787-1080$.

Hannon, L.J., and I car, E.M.. June 1990. Oil Spill Risk Analysis: Central and Western Gulf of Mexico (Proposed Lease Sales 123 \& 125) Outer Continental Shelf. MMS 90-0040. Accession No. PB90-240607. 133 p. Available from Minerals Management Service, Environmental Operations \& Analysis Branch, Room 3412, 381 Elden St., Herndon, VA 22070, telephone (703) 787-1644, and the National Technical Information Service, Springlield, VA 22161 .

Minerals Management Service. May 1989. Oil Spill Planning. Response Requirements, and Practices for Outer Continental Shelf Oil and (ias Operations. Report of the ()il Spill Response Task liorce. $28 \mathrm{p}$.

National Response Team. May 1989. The Exxon Valdez Oil Spill. A Report to the President. Samuel K. Skinner, Secretary, Dept. of Transportation, and William K. Reilly, Administrator, Environmental Protection Agency. 70 p.

- March 1989. The National Response Team. A Report on the National Oil and Hazardous Subsiances Response System. Annual Report.. 66 p.

Oil Spill Intelligence Report. Various Issues Throughout 1989 and 1990. Amy Stolls, ed. Cutter Information Corporation. Telephone 617) 641-5110.

Pybas, 1).W. 1987. Atlas of Artificial Reefs in Florida. Florida Sea Cirant Extension Bulletin. SGER-13. Gainsville, H. 26 p.

Reggio, V.C. 1987. The Use of Obsolete Petroleum Structures As Artificial Reefs: ()CS Report MMS 87-0015. Avalable from the Public Information Unit-()PS 3-4, Mineral: Management Service, 1201 Limwood Park Blid., New Orleans, I.A 70123-2394, (504) 736-2519.

1989. Petrole'um Structures As Artificial Reefs: A Compendium. lourth International Conference on Artificial Hathitats for lisheries, Rigs-to-Rects Special Session, November, 1987; Miami, 11.. ()CS Sudy MMS $89-() 021.176 \mathrm{r}$.

Report of the oCS Policy Commillec-Subcommitter to Review Analyses of the Eicum Valdez Oil Spill. May 23. $1940.26 \mathrm{p}$.

Trustc: Council August 1989. Siatellederal Natural Resource Damage Asse'ssment Plan for the Eacon Valdez (lil Spill Public keview Imafi $25 x$ ?. 


\section{Appendix A: Bibliography of OCS Information Reports}

The following is a regional listing of documents published by the OCS Information Program. Entries are arranged by title in reverse chronological order, listing the most recent publication first. Requests for copies of these publications should be directed to the following office:

Document Distribution Center

Technical Communications Services, MS 4530

Minerals Management Service

381 Elden St.

Herndon, VA 22070-4817

(703) $787-1080$ or (FTS) 393-108()

\section{Alaska Region}

\section{Arctic Subregion Summary Reports and Updates}

- Arctic Summary Report, January 1985, Outer (imbnental Shelf Oil and Gas Activities in the Arcte and their Onshore Impacts. Christopher WI. Lynch, Douglas i.. Slitur. and Robert $W$. Rudolph. 1985. OCS Information Repun. MMS 85.0022, L.S. DO1, 8t p.

- Arctic Summary Report Lpdate, September 19x3, Ouler Continental Shelf Oil and Gas Activities in the Aretic and their Onshore Impacts. Jeffrey 1.. Deis and Robert Person. 1983. L.S. DOI, $58 \mathrm{p}$

- Arctic Summary Report, January 198:, Ouler comtinemlal Shelf Oil and Gas Activities in the Arctic and their Onshore Impacts. Joanne Barnes Jackson and Frederick 1 Kurz. 1983. L'S. DO1, 81 p. Out of Primt

- Update 1, May 1982, Outer Continemal Shelf and Onshote Oil and Gas Activities and lmpacts in the Arele: A Summary Report. October 1981. Joanme Barnes Jackim and Barbara Cushmore Prea. 1982. LSGS Open-1.10 Report 82.19. L'S. DO1. $76 \mathrm{p}$

- Outer Concinental Sheif and Onshore O)! and (iats Activities and Impacts in the Arcic: A Summary Report. October 1981. Joanne Barmes Jackson, B. Fruts (ielden. Anne Stadnychenko, and Sharon Kolasmski. Whl l'slis Open-File Report 81-621. L's. BO1, 137"

\section{Bering Sea Subregion Summary Reports and Updates}

- Berang Sea Summary Report, September 19x4, Outer contunental Shelf Oil and (ias Activities in the Berme Sea and their Onshore Impacts. Jeffrey beis. 1984. OCS Information Report, MMS 84-0076. L.S. D)(01. 75 p.

- Bering Sea Summary Report, September 1983, Outer Continental Shelf Oil and (ias Actuvites in the Berme Sea and their (onshore Impacts. Jeffery Deis, Robert Pierson. and Frederick $\therefore$. Kurz 1983. L'S. DOl, ki p.

\section{Gulf of Alaska Subregion Summary Reports and Updates}

- Ciulf of Alaska Summary Report Lindate, May Mat. Outer Continental Shelf Oil and (ias Aclivities in the ciulf of Alaska and their Onshore Impacts. Jeffey 1). Wiese. 1984 OCS Information Report, MMS 84-0030, L.S. DOI, $27 \mathrm{p}$.

- Gulf of Alaska Summary Report Lidate, April 1963. (Oaker Continental Shelf $O$ il and (ics Activities in the (ialf of Alaska and their Onshore Impacts. Juanne Barnes Jackson. 1983. L.S. DO) 29 p.

- Ciulf of Alaska and lower cook lnket Summary Repert 3, June l982, Second Revision of Outer Comtinemtal Shell Oil and Cias Activities in the (iulf of Alaska cincluding lower Cook Inlet and their Oushore lmpacts: A Summary Keport, September logot. Joanc Bames Jackson and Frederick A. Kurt. 1982. LS(iS Open-like Report \$2.20. L.S. DOI, 79 p

- Ciulf of Alaska and Lower Cook Inkel Summary Report 2. June 1981, A Revision of Outer continemal Shelf (Jil and (ias Activities in the ciulf of Alaskit omeluding lowet cook Inlet) and their Onshure lmpacts: A Summary Report, September l9so. Karen M. Collins and Anme

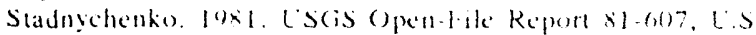
1)(O), fy $\mathrm{p}$

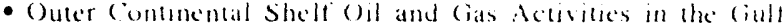
of Alaska cincluding lower cook Inlet) and their ()nshore lmpacts: A Summary Report, Seplember loxer. Jamme Barnes Jackson and Richard $T$. Burrete Pril. Istis Opentile Repurt s(1.102R, I S inci, 7s p. 


\section{Regionwide Alaska Summary Reports and Updates}

- Alaska Lpdate: September 1988-January 1990, Outer Continental Shelf Oil \& Gas Activities. Gregory J. Gould, Robert M. Karpas, and Douglas L. Slitor. 1990. OCS Information Report MMS 90-0012, $81 \mathrm{p}$.

- Alaska Lipdate: January 1987-August 1988, Outer Continental Shelf Oil and Gas Activities. 1988. OCS Information Report MMS 88-0073, 44 p.

- Alaska Summary Report (June 1984-December 1985) Outer Continental Shelf Oil and Gas Activities in Alaska and their Onshore Impacts. James H. Collins and Christopher W. Lynch. 1986. OCS Information Report, MMS 86-0023, L.S. DOI, $114 \mathrm{p}$.

\section{Alaska Indexes}

- Alaska Index (May 1983-January 1985). Denise D). Molajo 1985. OCS Information Report. MMS 85-0037, L.S. DOI. st p.

- Alaska Index 10ecember 1981-April 19831. Mary Ann rollignon. 1983. C.S. DO1, 74 p.

- Alaska Index 1December 1980-November 1981). Mary Ann Collignon. 1982. ISCiS Open-lile Report 82-18, L.S. DOI, $81 \mathrm{p}$.

- Alaska Index (December 1974-November 1980). Richard T. Dorrier. 1981. LSGS Open-file Report 81-20. L'.S. DOI, 85 p. Out of Print.

\section{Alaska Summary/Index}

- Alaska Summary/Index: January 1986-December 1986. D 1.. Shitor and J. D. Wiese. 1987. OCS Information Report, MMS $87-0016,99 \mathrm{p}$.

\section{Atlantic Region}

\section{North Atlantic Summary Reports and Updates}

\footnotetext{
- Vurth Atlantic Summary Repurt Lpdate, June 1983. Outer Continental Shelf Oil and (ias Activities in the North Alantic and their Onshore lmpacts. Alan $S$. Kurte and Jeffrey 1.. Deis. Iysi. L'S. !) O1, 23 p.

- Vorth Alantic Summary Report lipdate, lebruary 1983. Outer contincental Shelf Oil and (ias Aclivities in the North Alantse and their Onshere lmpacts. Jeffer 1. Deis $1983.13 .1) 01,33 \mathrm{p}$
}

- Update 1, April 1982, Outer Continental Shelf Oil and Gas Activities in the North Atlantic and their Onshore Impacts: A Summary Report. Jeffrey L. Deis and Elizabeth $O$. Porter. USGS Open-File Report 82-16, U.S. DO1, 42 p.

- Outer Continental Shelf Oil and Gas Activities in the North Atlantic and their Onshore Impacts: A Summary Report, July 1981. Richard T. Dorrier. 1981. USGiS Open-File Report 81-601, U.S. DOI, 65 p.

\section{Mid-Atlantic Summary Reports and Updates}

- Mid-Atlantic Summary Report, Octuber 1983, Outer Continental Shelf Oil and Gas Activities in the Mid-Atlantic and their Onshore Impacts. Alan S. Kurtz and Jeffrey L. Deis. 1983. U.S. DOI, 44 p.

- Mid-Atlantic Summary Repurt 2, October 1982, Outer Continental Shelf Oil and Gas Activities in the Mid-Atlantic and their Onshore Impacts. Jeffrey L. Deis and Frederick N. Kurz. 1982. U.S. DOI, 63 p

- Update 3, August 1981, Outer Continental Shelf Oil and Gas Activities in the Mid-Atlantic and their Onshore Impacts. Catherine A. McCord. 1981. LiSGS Open-File Report 81-619, U.S. DOI, 12 p.

- Lipdate 2, February 1981, Outer Continental Shelf Oil and Gas Activities in the Mid-Allantic and their Onshore Impacts. Richard T. Dorrier. 1981. USGS Open-File Report 81-603, U.S. DOI, $18 \mathrm{p}$.

- Update 1, June 1980, Outer Continental Shelf Oil and Gas Activities in the Mid-Allantic and their Onshore Impacts. Jeffrey L. Deis. 1980. Lipdate to USGS Open-File Report 80-17, U.S. DOI, 18 p.

- Outer Continental Shelf Oil and Gas Activities in the Mid-Atlantic and their Onshore Impacts: A Summary Report, November 1979. George S. Macpherson and Charles A. Bookman. 1980. USGS Open-File Report 80-17, U.S. DOI, 63 p.

\section{South Atlantic Summary Reports and Updates}

- South Allantic Summary Report, December 1983, Outer Continental Shelf Oil and Gas Activities in the South Atlantic and their Onshore Impacts. Kenneth $j$. Havran and Jeffrey D. Wiese. 1984. L'S. DO) I, 34 P

- South Atlantic Summary Report Lpdate, February 1983. Outer Continental Shelf Oil and (ias Activities in the South Atlantic and their Onshore Impacts. Kenneth J. Havran. 1983. L'S. 1)(O), 20 p.

- South Atlantic Summary Report 2, May 19x2, ()uter Continental Shelf Oil and (ias Activities in the South Alantic and their Onshore Impacts. Jeffrey 1. Deis,

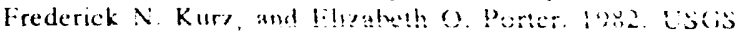
Open-lite Report 82-15, (i.S. I)( )1, 50 p. 
- Lipdate 2, August 1981, Outer Continental Shelf Oil and Gas Activities in the South Atlantic (U.S.) and the ir Onshore Impacts: A Summary Report, July 1980. Catherine A. MeCord. 1\%R: USGS Open-lite Report 81-616, U.S. DOI, 13 p.

- Uipdate 1, February 198, Outer Continental Shelf Oil and Gas Activities in the South Atlantic (U.S.) and their Onshore Impacts: A Summary Report, July 1980. Kenneth J. Havran. 1981. USGS Open-File Report 81-25, U.S. DOI, $14 \mathrm{p}$

- Outer Continental Shelf Oil and Gas Activities in the South Allantic (U.S.) and their Onshore Impacts: A Summary Repon, July 1980. Joanne Barnes Jackson. 1980 USGiS Open-File Report 80-626, U.S. DOI, $62 \mathrm{p}$.

\section{Regionwide Atlantic Summary Report}

- Atlantic Lipdate: July 1986-Sune 1990, Outer Continental Shelf Oil and Gas Activities. "inbert M. Karpas and Gregory J. Gould. 1990. OCS Information Report, MMS $90-0060$, U.S. 1001,57 p.

- Allanic Summary Report, December 1984, Outer Continental Shelf Oil and Gas Activities in the Atlantic Region and their Onshore lmpacts. Robert W. Rudolph and Kenneth J. Havran. 1985. OCS Information Report, MMS 85-(x)21, L.S. DOI, 74 p

\section{Atlantic Indexes}

- Allantic Index (June 1984-January 1985). Christopher W'. Lynch and Denise D. Molajo. 1985. OCS Information Report, MMS 85.0036, L'.S. 1)OI, $114 \mathrm{p}$.

- Alantic Index (June 1983-May 1984). Mary Ann collignon. 1984. OCS information Report. MMS 84-0050. (.S. 1)( $113 \mathrm{p}$

- Mllantic Index (June 1981-.May 1983). Catherine $A$ Ifcourd 1983. L.S. DO). $120 \mathrm{p}$.

- Alantic Index (December 1980-June 1981). Mary Ann Collignon. 1981. LSCiS Open-File keport 81-705, L.S 1)O1, $173 \mathrm{p}$.

- Allantic Index (January 1975-November 1980). Martha Alison Salemann. 1981. LSCiS Open-lile Report $80-1202$, ('.S. 1)01, 193 P.

\section{Atlantic Summary/Index}

- Allantic Summaryllndex January lok5-June 1980, Ouler Contunental Shelf Oil and (ias schivilies. Jeffey D. Wiese

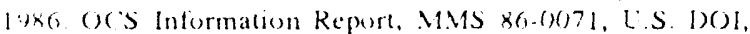
ix $\mathrm{P}$

\section{Gulf of Mexico Region}

\section{Gulf of Mexico Summary Reports and Updates}

- Gulf of Mexico Update: May 1988-July 1989. Onter Continental Shelf Oil and Gas Activities. Gregory J. Gould. 1989. OCS Information Report, MMS 89-0079, U.S. DOI, $51 \mathrm{p}$.

- Gulf of Mexico Update: July 1986-April 1988, Outer Continental Shelf Oil and Gas Activities. 1988. OCS Information Report, MMS 88-0(138, U.S. DOI, 39 p.

- Gulf of Mexico Summary Report/Index, November 1984-June 1986, Outer Continental Shelf Oil and Gas Activities in the Gulf of Mexico and their Onshore Impacts. Stephen P. Risotto and James H. Collins. 1986. OCS Information Report, MMS 86-0084, U.S. DOI, 102 p.

- Gulf of Mexico Summary Report, October 1984-June 1985, Outer Continental Shelf Oil and Gas Activities in the Gulf of Mexico Region and their Onshore Impacts. Christopher W. Lynch and Stephen P. Risolto. 1985. OCS Information Report, MMS 85-0083, U.S. DOI, lu8 p.

- Gulf of Mexico Summary Report, September 1984, Outer Continental Shelf Oil and (ias Activities in the Gulf of Mexico Region and their Onshore Impacts. Christopher W'. Lynch and Robert W'. Rudolph. 1984. OCS Information Report, MMS 84-0073, U.S. DOI, 108 p

- Gulf of Mexico Summary Report, September 1983, Outer Continental Shelf Oil and Gas Activities in the Gulf of Mexico Region and their Onshore Impacts. Jeffrey D. Wiese, Douglas L. Slitor, and Catherine A. McCord. 1983. U.S. DOI, $106 \mathrm{p}$.

- Gulf of Mexico Summary Report 3, August 1982, Outer Continental Shelf $O$ il and Gas Activities in the Gulf of Mexico Region and their Onshore Impacts. Kenneth $J$. Havran, Jeffrey D. Wiese, Karen M. Collins, and Frederick N. Kurz. 1982. USGis Open-File Report $82-242$, (.S. 1)Ol, $99 \mathrm{p}$.

- Gulf of Mexico Summary Report 2, August 1981, Outer Continental Shelf Oil and Cas Activities in the Gulf of Mexico Region and their Onshore Impacts. Kenneth J. Havran. 1981. LSGS Open-File Report 81-620, L.S. DOI, $79 \mathrm{p}$.

- Outer Continental Shelf Oil and (jas Activities in the Gulf of Mexico and their Onshore Impacts: A Summary Report, September 1980. Venneth J. liavran and Karen $M$. Collins. 1980. LScis open-Flle Report 80-864, L'S. D)Ol, $102 \mathrm{p}$.

\section{Gulf of Mexico Indexes}

- Ciulf of Mexico Index (August 1983-October 1984). Denise 1). Molajo, Stephen P. Risotto, and Virgina A. Farris. 1984. OCS Information Report, MMS $\times 5.0043$, L.S. DOI, $86 \mathrm{p}$. 
- (iulf of Mexico Index (September 1982.July 1983). Mary Am Colligmon. 1983. L.S. DOI, 125 p.

- (iulf of Mexico Index (December 1980-August 1982). Mary Ann Collignon. 1982. Li.S. DOI, $157 \mathrm{p}$.

- (iulf of Mexico Index (January 1978-November 1980). Kenneth J. Mavran, Karen M. Collins, Richard T. Dorricer, and Mary Ann Collignon. 1981. LSCiS Open-lile Report $81-313$, L'S. DO1, 181 p.

\section{Pacific Region}

\section{Pacific Summary Reports and Updates}

- Pacitic Lodale: Augusl 1987-November 19x9, Outer Combmental Shelf Oil and (ias Activities. Douglas L. Sliker, Jeffrey D. Wiese, and Robert M. Karpas. 1990. oCS Information Report, MMS $90-0013,2 . S$. DOI, $100 \mathrm{p}$

- Pacific Summary Report, April 1985, Outer Continental Shelf Oil and Gas Activities in the Pacific and their ()nshore Impacts. Robert $W^{\prime}$. Rudolph and Paul M. Nikituk. 1985 . OCS Information Report, MMS 85-0040, L.S. 1)(3. () $\mathrm{p}$

- Hacilic Summary Report, July 1984, Outer Continental Shelf (O) and (ias Activities in the Pacific and their Onshore Impacts. Kemeth J. Havran and Christopher W. Iynch. I9x4. OCS Information Report, MMS $84-0075$. (.s. DO) . $44 \mathrm{p}$

- Pacitic Summary Report, September 1983, Outer (ontinental Shelf Oil and (ias Activities in the pacific and ther Onshore Impact. Kenneth J. Havran. 1983. L:S 1)O!, 103 p.

- Pacific Summary Report, December 1982, Ouler Contunental Shelf Oil and Gas Activities in the Pacific and their Onshore Impacts. 1983. Anne Stadnychenko and (atherne Mecord. L.S. DOS, I09 p. Out of Print

- Pacific Summary Report 2, May 1982, A Revision of

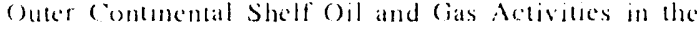
Pacitic (Southem (allformat) and their Onshore lmpacts: A Summary Report, May lexo. Karen M. Collins. (atherine A Mecord, Anne Stadnychenko, and Peter

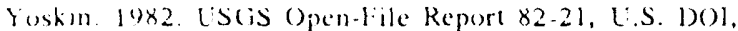
$121 \mathrm{P}$.

\begin{abstract}
- Outer Continental Shelf Oil and Gas Activities in the Pacific (Southern (alifornia) and their Onshore Impacts: A Summary Report, May 1980. George $S$. Macpherson and Janis Bernstein. 1980. USGS Open-File Report 80-645, U.S. DOI, 134 p.
\end{abstract}

\section{Pacific Indexes}

- Pacific Index (April 1983-October 1984). Denise D. Molajo. 1985. OCS Information Report, MMS 85-0004, L.S. IOI, 84 p.

- Pacific Index (July 1981-March 1983). Jeffrey D. Wiese and Mary Ann Collignon. 1983. U.S. DOI, 86 p.

- Pacific Index (November 1980-June 1981). Mary Ann Collignon. 1981. USCiS Open-lile Report 81-708, U.S. I)( $1,89 \mathrm{p}$.

- Pacific Index (January 1962-October 1980). Sharon L. Kolasinski. 1980. USGS Open-File Report 80-1201, U.S. DOI, $111 \mathrm{p}$.

\section{Pacific Summary/Index}

- Pacific Summary ReportIndex: June 1, 1986- July 31 , 1987. Outer Continental Shelf Oil and Gas Activities. Jeffrey D. Wiese and Douglas I.. Slitor. 1987. OCS Information Report, MMS 87-0078, U.S. DOI, 140 p.

- Pacific Summary ReporvIndex: Novemuer 1984-May 1986. Outer Continental Shelf Oil and Gas Activities in the Pacific and their Onshore Impacts. Stephen Risotto and Robert Rudolph. 1986. OCS Information Report, MMS $86-0060,115 \mathrm{p}$

\section{National}

- OCS National Compendium, Outer Continental Shelf Oil and Cas Information 'Through October 1990. Gregory J. (iould, Robert M. Karpas, and Douglas L. Slitor. 1991. OCS Information Report, MMS 91-0032, U.S. DOI, _- p.

- OCS National Compendium, Outer Continental Shelf Oil and Cias Information Through September 1988. Gregory J. (iould. 1989. OCS Information Report, MMS 89-0043, (i.S. $D() 1,131$ p.

- OC'S National Compendium, Outer Continental Shelf Oil and Gas Information Through 1984. Paul M. Nikituk and Virginia A. Fatris. 1986 . OCS Information Report, MMS 86-(K)17, L.S. DOI. $172 \mathrm{p}$

- OCS Directory, federal and State Agencies and Their OrS-Related Responsibilities. 1900 . OCS Information Report, MMS 9()-()064, L'.S. DOI, 177 p. Print On Hold.

- OCS Directory, lederal and State Agencies and Their OCS-Related Respensibilities. 1988. OCS Information Reporl, MMS $8 x-005 x$, L.S. 1)(O), 149 p. Copies no longer avarabive 


\section{Other Documents of Interest}

- Federal Offshore Statistics: 1989, Leasing, Exploration. Production. \& Revenues. 1990. OCS Repurt MMS 90-0072, U.S. DOI, 104 p.

- Federal Offshore Statistics: 1988, 1.easing, Fxploration, Production. \& Revenues. $19 \times 9$. OCS Report MMS 89.0082, U.S. DOI. 102 p.

- Oil and Gas Leasing/Production Program: Annual RepordFY 1989. 1990. Annual. OCS Report MMS 90-(0)15, $40 \mathrm{p}$.

- Oil and Gas Leasing/Production Program: Ammal ReporUFY 1988. 1989. Annual. OC'S Report MMS 89.0055. $55 \mathrm{p}$

- Oil and Gas Leasing/Production Program: Annual ReporvFY 1987. 1988 Annual. OCS Report MiSS $8 \times .00(10)$ $36 \mathrm{p}$

- Offshore Scientific and Technical Publications, Summer 1989//Fall 1989. Quarterly. Offshore Inturnation \& Publications, $30 \mathrm{p}$.

- Offshore Scientific and Technical Publications. 1984 Annual. OCS Report MMS 86-0010, 15 p.

- Offshore Scientific and Technical Publications. 1985 Annual. OCS Report MMS 87-(1)81, 16 p.

- Offshore Scientific and Technical Puhlications. 1986 Annual. OCS Report MMS 88-0055, 20 p.

- Offshore Scientific and Technical Publications. $19 \times 7$ Annual. OCS Report MMS 90-0004, 20 p.

- OCS Laus, Related to Mincral Resource Activities on the Outer Continental Shelf. 1985. Offshore Information \& Publications, OCS Report MMS 85-0069, une volume.

- OCS Regulations Related to Mineral Resource Activi.jes on the Outer Continental Shelf. 1989. Offshore Information \& Publications. MMS $88-(0) 26$, one volume.

\section{Other Items of Interest}

The OCS Information Program is now producing a map series. The following oversized plates have already been published.

- Maska Map Series. OCS Map, MMS xo-0101 13 plates: Arctic, Bering, (hukchu).

- Pacific Map Series. (oc Map, MMS 890100 (1) plates. 


\section{Appendix B. Geologic Reports Available from MMS}

The following list of geologic reports are available from MMS. OCS reports are available for reicew at the MMS's Document Distribution Center in Herndon, Virginia.
All other reports are available while supplies last through the regional offices at the following addresses:
Alaska

lithrary

Alisika OCS Region

Minerals Management Service

449 liast 36 th Ave., Room 110

Anchorage, AK 99508-4302

(90) 261.4435

Gulf of Mexico

Puhlic Intormation

Gulf of Mexico ()CS Reigon

Mincrals Management Service

1201 1:Lmwood Piuk B16u.

New ()rlcans, IA 70123

(.5)4) $736-2519$

\section{Atlantic}

Public Information Oflicer

Atlantic ()CS Region

Minerals Management Service

381 Elden St., MS 4610

Herndon, VA 22070-4871

(70)3) $787-1113$

Pacific

Public Affairs

Pacific ()CS Region

Mincrals Management Survice

770) Paseo Camarillo

Camarillo, CA 93010)

(805) 389.7502
Headquarters

Document Distribution Center

Technical Communication Services

Minerals Management Service

381 Eilden St., MS 4530)

Herndon, VA 2207(0)-4817

17(1)3) 787.108

\begin{tabular}{|c|c|c|c|}
\hline Report No. & Title & Author & ublished \\
\hline $0(x-0)(1)$ & $\begin{array}{l}\text { Geological and operational summary, COST No. B-2 well, } \\
\text { - Baltimore Canyon Trough area, Mid-Atlar.ic OrS. }\end{array}$ & MA Smih, el al. & 1976 \\
\hline$(x)(s-1)(x) 2$ & $\begin{array}{l}\text { Geologic and operational summary, COST No. B-3 well, } \\
\text {-Baltimore Canyon Trough area, Mid-Atantic OCS. }\end{array}$ & R.V. Amatu \& FE.K. Simmonis & 1979 \\
\hline$(x)-(0) 0)$ & $\begin{array}{l}\text { (ieologic and operational summary, COST No. (i-1 well, } \\
\text { - Georges Bank area, North Allantic OCS. }\end{array}$ & R.V. Amate \& J.W. Bebout & 1980 \\
\hline$(x) S-\cos (1) 4$ & $\begin{array}{l}\text { Ceologic and operational summary, COST No. (i-2 well, } \\
\text { - Cieorges Bank area, North Atlantic OCS. }\end{array}$ & R.V. Amato \& E.K. Simonis & 1980 \\
\hline$(x)-0(x)(0)$ & $\begin{array}{l}\text { (ieological and operational summary, COST No. Git-1 well, } \\
\text {--Southeast Georgia timbayment area, South Atlantic OCS. }\end{array}$ & R.V. Amato \& J.W'. Bebout & 1978 \\
\hline $0(3-0) 006$ & $\begin{array}{l}\text { Geological studies of the COST No. GE-1 well, Linited States } \\
\text { - South Atlantic Outer Continental Shelf area. }\end{array}$ & P.A. Scholle & 1979 \\
\hline$(x)-(x) 7$ & 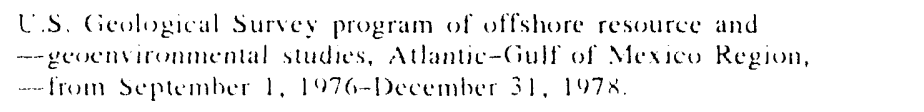 & D.W. Folger \& S.W. Needell & $19 \times 3$ \\
\hline$(x \mathrm{~s}-()(x)$ & 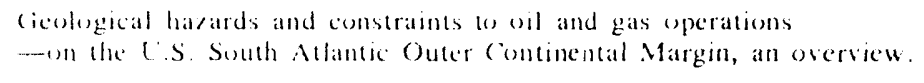 & B.S. Drucker & $19 \times 3$ \\
\hline$(x)-(x) 11$ & 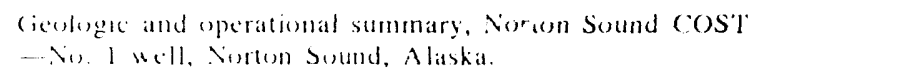 & R.l lumer, et al. & 1983 \\
\hline$(x)+x) 2$ & 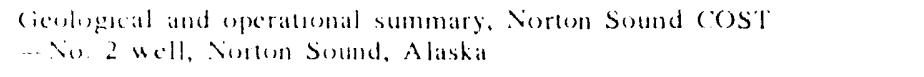 & R.I. 'lumer, et al. & $19 \times 3$ \\
\hline (c) $s-1, x$ & 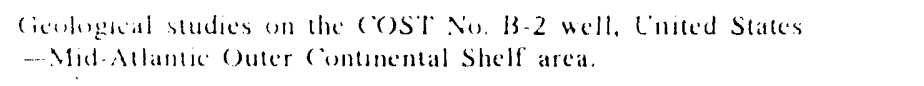 & P.A. Scholle & 1977 \\
\hline (x) $1305 x$ & 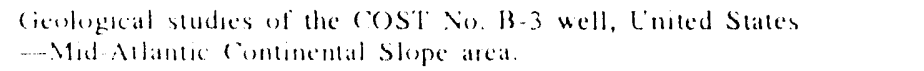 & P.A Scholle & $19 x(1$ \\
\hline
\end{tabular}




\begin{tabular}{|c|c|c|c|}
\hline \multirow{2}{*}{$\frac{\text { Report No. }}{O(S-0059}$} & \multirow{2}{*}{$\begin{array}{l}\text { Title } \\
\text { Geologica! studies of the cos! No. (i-1 and (i-2 wells, } \\
\text { - Lnited States North Atlantic Outer Contunental Shelf. }\end{array}$} & Author & Publisheo \\
\hline & & P.A. Scholle \& C.R. Wenkam & 1982 \\
\hline$O C S-0100$ & $\begin{array}{l}\text { Geologic estimates of undiscovered recoverable oil and } \\
\text { - gas resources in the United States. }\end{array}$ & B.M. Miller, et al. & 1975 \\
\hline OCS-0211 & $\begin{array}{l}\text { Geologic framework, petroleum potential, petroleum resource } \\
\text {-estimates, environmental hazards, and deep-water drilling } \\
\text { - lechnology of the Maritime Boundary region, offshore } \\
\text { - Southern Californa Borderiand. }\end{array}$ & R.B. Powers & 1981 \\
\hline OCS-0222 & $\begin{array}{l}\text { Geologic studies of the Point Conception deep stratigraphic } \\
\text {-test well OCS.CA1. } 76-164 \text {. Vo. 1. Outer Continental Shelf } \\
\text { - Southern California, Enited States. }\end{array}$ & HIE. Cook & 1979 \\
\hline OCS-0237 & $\begin{array}{l}\text { Geologic and operational summary, Southern California deep } \\
\text { - stratigraphic test OCS-CAL. } 75-70 \text { No. 1, Cortes Bank area } \\
\text {-offshore Southern Calitornta. }\end{array}$ & R.ci. Paul, ct al. & 1976 \\
\hline$O F R-75-174 a$ & $\begin{array}{l}\text { Geological and operational summary continental offshore } \\
\text { - stratigraphic test cCOST) no. I. South Padre Island east } \\
\text {-addition, offshore South l'exas: L.S. Cicological Survey }\end{array}$ & A.S. Khan \& others & 1975 \\
\hline$O F R-75.259 b$ & $\begin{array}{l}\text { Geological and operational summary continental offshore } \\
\text { - stratrigraphic test (COST) no. 2, Mustang Island, of fshore } \\
\text { - South Texas: L.S. Ceological Survey }\end{array}$ & A.S. Khan \& others & 1975 \\
\hline $81-265$ & $\begin{array}{l}\text { Geologic Framework, Petroleum Potential, Petroleum-resuurce } \\
\text { - Estimates, Mineral and Cieothermal Resources, Geologic } \\
\text { - Hazards, and Deep-water Drilling Technology of the Maritime } \\
\text { - Boundary Region in the Gulf of Mexico, } 211 \text { p. } \\
\text { - KCompanion (iOM Report] }\end{array}$ & R.B. Powers & 1981 \\
\hline $84-339$ & $\begin{array}{l}\text { Summary report on the regional geology, petroleum potential } \\
\text {-environmental consideration for development, and estimates of } \\
\text { - undiscovered recoverable oil and gas resources of the United } \\
\text { - States (julf of Mexico Continental Margin in the area of } \\
\text { - proposed Oil and Cias Lease Sales Nos. } 81 \text { and } 84 \text {. }\end{array}$ & R.Q. Foote, ed. & 1984 \\
\hline$x+40(1) 22$ & Geology report, proposed Mid-Atlantic OCS oil and gas lease sale 111 & G.B. Carpenter \& R.V. Amato & 1984 \\
\hline $84-0062$ & $\begin{array}{l}\text { Geology report, proposed North Atlantic OCS oil and gas } \\
\text {---lease sale } 96 .\end{array}$ & G.B. Carpenter \& R.V. Amato & 1985 \\
\hline $85-0012$ & $\begin{array}{l}\text { Fstimates of undiscovered, economically recovirable oil and } \\
\text {-gas resources for the Outer Continental Sheli } \ldots \text { of July } 1984 .\end{array}$ & L.W. Cooke & 1985 \\
\hline $85-0042$ & Proposed Soutiern Califomia Planning Area, OCS lease sale 95 & $\begin{array}{l}\text { F.L. Webster, L. J. Burdick, } \\
\text {-D.G. Griggs \& K.A. Yeme }\end{array}$ & 1985 \\
\hline $85-0045$ & $\begin{array}{l}\text { Geologic report for the Vavarin Basin Planning Area, Bering } \\
\text {-Sea, Alaska. }\end{array}$ & $\begin{array}{l}\text { R.F. Turner, G.C. Martin } \\
\text {-T.O. Flett \& D.F. Risley }\end{array}$ & 1985 \\
\hline $85-0101$ & $\begin{array}{l}\text { Pacific OCS lease sale, October 1, 1964, Oregon and } \\
\text {-Washington. }\end{array}$ & F.1. Webster & 1985 \\
\hline $85-011 !$ & $\begin{array}{l}\text { Ceologic report for the Beaufort Sea Planning Area, Alaska: } \\
\text { - Regional geology. petroleum geology, envirommental geology. }\end{array}$ & $\begin{array}{l}\text { J.D. Craig, K.W. Sherwood } \\
\text { - \& P.P. Johnson }\end{array}$ & 1986 \\
\hline$\because 0-0)(125$ & $\begin{array}{l}\text { Cieologic report, proposed Northern California Planning Area, } \\
\text {-OCS lease sale } N 0.91 .\end{array}$ & $\begin{array}{l}\text { I.L. Webster, D.J. Burdick } \\
-\& \text { K.A. Yenne }\end{array}$ & 1986 \\
\hline$\times 6-0033$ & $\begin{array}{l}\text { Geologic report for the Norton Basin Planning Area, Bering } \\
\text {-Sea, Alaska. }\end{array}$ & $\begin{array}{l}\text { R.F. Turner, ed., (i.C. Martin, } \\
-\& \text { D.E. Risley }\end{array}$ & 1986 \\
\hline $86-0048$ & Lnited States Outer continental Shelf basins: Maps and descriptions. & (i. Dellagiarino & 1986 \\
\hline $86.00,7$ & $\begin{array}{l}\text { oc's Report lenneco lludson (anyon } 642.2 \text { well, geological } \\
\text {-and operatonal summary. }\end{array}$ & L..1: Bielak & 1986 \\
\hline$x 6.0099$ & $\begin{array}{l}\text { OC'S Report Shell Wilmmeten (anyon } 5 \times 6-1 \text { well, geologicial } \\
\text {-and operatmol summary. }\end{array}$ & G.M. Idson & $19 \times 6$ \\
\hline$x(1.0117$ & $\begin{array}{l}\text { OCS Repurt Murphy Witmungtum (anyen log-1 well, geolegical } \\
\text {-and operatunal summary. }\end{array}$ & Frederick Adinolfi & 1986 \\
\hline$x 6 .(1) 2 x$ & $\begin{array}{l}\text { oc S Report Shell Ballumere Rise } 93.1 \text { well, geological } \\
\text {-and operational summary. }\end{array}$ & R.V. Amato & $19 \times 6$ \\
\hline
\end{tabular}


Report No. Title

Author

Published

86.0124

$87-6000$

$87-0026$

$87-0030$

$27-60)+6$

$x>007+$

$\times 7-0108$

37.0118

$87-0199$

$88-0047$

$88-0081$

$89-0007$

$89-0027$

$90-0082$
OCS Report. Texaco Hudson (anyon Syx-z well. geologual -and opeatuonal summars

Cieological and geophysical data acquasillon, Outer - Continental shelf through fiscal year 1985. resource -evaluation program report

Correlation of Cenoloic sediments, (iulf of Mexico Outer -Continental Shelf, Part 1: Galveston area offshore Texas - through Vermillion ares offshore Lousiana.

Geologic report for the $S t$. (ieorge Basin planning area, - Bering Sea, Alaska

Geologic report for the Chukch Sea plaming area, Alaska. OCS Report. Shell Wilmington Canyon 587.1 well, geological -and operational summars.

Northern and Central Califurma lease sale, May 14. 1963.

-Pacific Outer Continental Shelt.

OCS Report. Shell Wilmington canson 372.1 well, geological -and operational summary.

Goological and operational summary. Kodiak Shelf - stratigraphic test nells, western Giulf of Alaska.

Estimates of oil and gas reserves, Pacific Outer Continental - Sheif as of December 31.1987.

Central Cahforna Planning Area Cicoleg: Report:

Exan Lydunia Canyon 133.1 Hell: Coological and -operational summary.

Texaco Hudson campon 642-1 uell: (icological and -operational summary.

Estamated onl and gats reserses, (iulf of Mexico.

-December 31 . 19xi
B.J. Kolviski

$10 \times 6$

(i.B. Tires, 1). Zinzer

- \& Priton

J.C. Reed, C.1. L levendecker, -A.S. Kahn, C.J. Kinler.

-P.F. Harrison \& G.P. Pickens

C.D. Comer, B.M. Herman,

-\& S.A. Zeruick

D.K. Thurston \& L.A. Theiss 19k'

- (i.). lidson

1987

F.l. Wehster \& K.A. Yenne $19 \times 7$

G.M. Fidson

$198 x$

R.F. Turner, ed

1988

P.J. Raftery \& S.A. Wolfson

1988

F.L. Webster, D.J. Burdick

1989

-\& KA. Yenne

Karen Riccardi

R.' Amato \& L.F. Biclak

1990

J.M. Velancon, J.P. Brooke, 1990 


\section{OCS Information Program Publication Staff}

\section{Program Cocrdinator:}

Douglas L. Slitor . . . . . . . . . . . . (703) 787-1030

Author/Technical Coordinator:

Gregory J. Gould . . . . . . . . . . . . (703) 787-1029

\section{Supporting Authors:}

Robert M. Karpas . . . . . . . . . . . . . (703) 787-1027

Douglas L. Slitor . . . . . . . . . . . (703) 787-1030

\section{Editor/Production Coordinator:}

Mary J. Davis . . . . . . . . . . . . (703) 787-1028

Technical Support/Graphics:

Mary Beth Barbagallo . . . . . . . . . . (703) 787-1034

Production Support:

Dayle Grover . . . . . . . . . . . . . . (703) 787-1032

Distribution:

Peggie Russell . . . . . . . . . . . . . . . (703) 787-1080 


\section{OCS Information Program}

Operations \& Safety Management

Minerals Management Service, MS 4610

381 Elden Street

Herndon, Virginia 22070-4817

\section{OCS Information Program}

Operations \& Safety Management

Minerals Management Service, MS 4610

381 Elden Street

Herndon, Virginia 22070-4817 


\section{OCS National Compendium-October 1990}

YES! Place my narne on your mailing list to receive the 1993 Compendium.

Name

Organization

(Please type or print)

Address

City

State

Zip

Phone

Comments

U.S. Department of the Interior

Minerals Management Service

MMS 91-0032

\section{OCS National Compendium-October 1990}

YES! Place my name on your mailing list to receive the 1993 Compendium.

Name

Organization

(Please type or print)

Address

City

St'ste

Zip

Phone

Comments 
As the Nation's principal conservation agency. the Department of the Interior has responsibility for most of our nationally owned public lands and natural resources. This includes fostering the wisest use of our land and water resources, protecting our fish and wildlife. preserving the environmental and cultural values of our national parks and historical places, and providing for the enjoyment of life through outdoor recreation. The Department assesses our energy and mineral resources and works to assure that their development is in the best interest of all our people. The Department also has a major responsibility for American Indian reservation communities and for people who live in Island Territories under U.S. Administration.
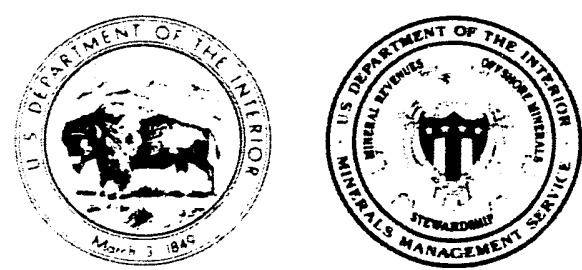

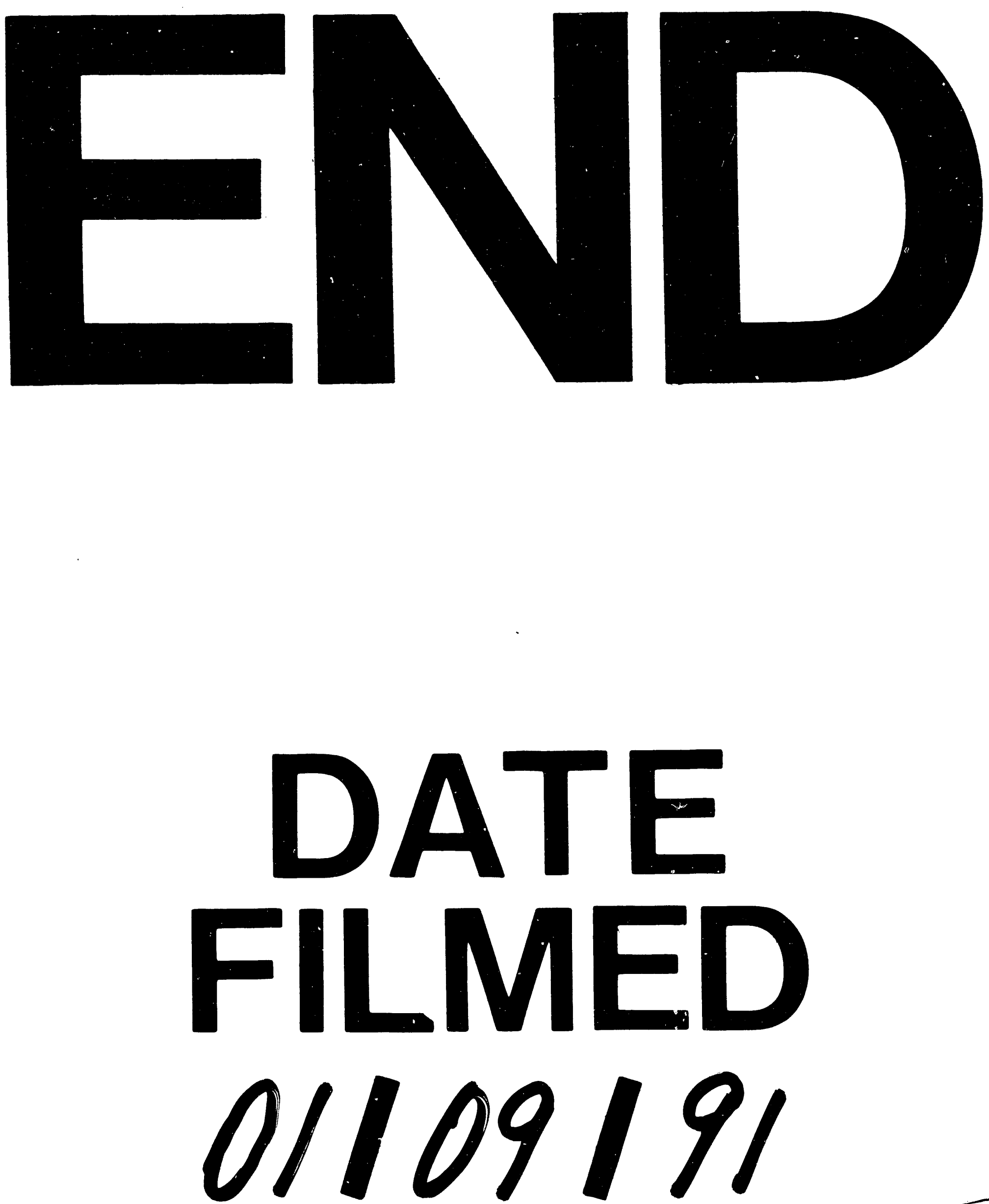

- 
